\title{
Human Duties and the Limits of Human Rights Discourse
}

\author{
Proefschrift
}

ter verkrijging van de graad van doctor aan de Radboud Universiteit Nijmegen op gezag van de rector magnificus prof. dr. Th.L.M. Engelen, volgens besluit van het college van decanen in het openbaar te verdedigen op dinsdag 17 november 2015 om 12:30 uur precies

$$
\text { door }
$$

Eric Robert Boot

geboren op 13 juli 1984

te Racine, Verenigde Staten van Amerika 


\section{Promotor: \\ Prof. dr. T.J.M. Mertens}

Copromotor:

Dr. R.B.J. Tinnevelt

Manuscriptcommissie:

Prof. mr. J.H. Gerards

Prof. dr. A. Pinzani (Universidade Federal de Santa Catarina, Brazilië)

Prof. dr. K.C. Tan (University of Pennsylvania, Verenigde Staten van Amerika)

Prof. dr. J. Timmermann (University of St Andrews, Schotland)

Prof. dr. A. Vandevelde (KU Leuven, België)

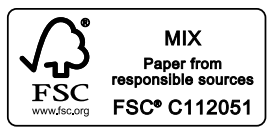

Copyright @ 2015 by Eric Robert Boot

Design: Juliet Campfens

Cover image: Ambrogio Lorenzetti, “Allegoria del buon governo” (detail), 1339.

Printed and bound by Ipskamp Drukkers, Enschede (the Netherlands)

This research was financially supported by the Netherlands Organisation for Scientific Research (NWO) in the framework of the project "Human Rights and Human Duties: Assessing the Obligations Entailed in Human Rights" 
All philosophy, my dear Cicero, is fecund and fruitful, and no part of it is wasteland and barren; but no topic within it is more fertile and productive than that of obligations, for from them are derived the principles of consistent and honourable living.

Cicero 


\section{CONTENTS}

ACKNOWLEDGEMENTS

LIST OF ABBREVIATIONS

INTRODUCTION

CHAPTER 1

THE DEBATE CONCERNING HUMAN DUTIES

§1.1 - Human Duties Declarations: The Problem $\quad 24$

§1.2 - Critique of Human Duties Declarations $\quad 29$

§1.3 - Human Duties in International Human Rights Law $\quad 34$

\$1.3.1 - Negative Individual Human Duties in International Human Rights Law $\quad 35$

§1.3.2 - Positive Individual Human Duties in International Human Rights Law $\quad \mathbf{4 0}$

$\begin{array}{ll}\text { §1.4 - Conclusion: Human Duties Compared } & 48\end{array}$

$\begin{array}{ll}\text { CHAPTER } 2 & 54\end{array}$

DUTIES AND RIGHTS

\$2.1.1 - Perfect and Imperfect Duties $\quad \mathbf{5 6}$

\$2.1.2 - Duties of Justice and Duties of Virtue $\quad 70$

§2.1.3 - The Relation Between Justice and Virtue $\quad 76$

$\begin{array}{ll}\text { §2.2 - On Rights } & 82\end{array}$

\$2.2.1 - What Are Rights? $\quad 83$

§2.2.2 - The Perspective of Rights and the Perspective of Duties $\quad 89$

$\begin{array}{ll}\text { \$2.3 - Conclusion: An Overview } & 94\end{array}$

$\begin{array}{ll}\text { CHAPTER } 3 & 98\end{array}$

TWO CONTENTIOUS DUTIES

§3.1 - International Individual Duties of Aid $\quad 99$

§3.2 - The Role and Significance of Duties to the Community within the Universal Declaration $\quad 109$

§3.2.1 - Drafting History $\quad 110$

$\begin{array}{ll}\S 3.2 .2 \text { - Interpretation } & 114\end{array}$

§3.2.3 - What Duties? $\quad 123$

$\begin{array}{ll}\S 3.3 \text { - Conclusion } & 131\end{array}$ 
SUBSISTENCE NEEDS AND INDIVIDUAL DUTIES

§4.1 - Who Has What Duties in Fulfilling Subsistence Needs? $\quad 135$

$\S 4.2$ - What Is the Status of Our Duties Concerning the Fulfillment of Subsistence Needs? 142

§4.3 - Do Subsistence Needs Give Rise to a Human Right to Subsistence? 159

$\S 4.4$ - Conclusion: The Mutual Dependence of Just Institutions and Virtue $\quad 168$

CHAPTER 5

172

DUTIES TO THE COMMUNITY AND CIVIC VIRTUE

$\S 5.1$ - An Instrumental Argument for Civic Duties: A Rebuttal of Two Counterarguments

§5.1.1 - Two Problems with Limitless Freedom

$\S 5.2$ - The Importance of Civic Virtue

186

\$5.2.1 - The Problem of Strict Liberal Neutrality

190

\$5.2.2 - When Is It Legitimate for the State to Concern Itself With Its Citizens' Virtue?

193

\$5.2.3 - In What Manner May the State Cultivate Civic Virtue?

198

$\S 5.3$ - Conclusion: Virtue as Complement to Justice

CONCLUSION 


\section{ACKNOWLEDGEMENTS}

It was the end of April, 2011. I had injured my ankle playing soccer only a week before, so when I was called in for my interview I had to fumble my way into the room on crutches. Facing me were four people who would be of great help during my doctoral studies. Sitting across from me was my future supervisor Thomas. The fact that I finished my dissertation (more or less) on time is in large measure thanks to him, as he, from the very beginning, impressed upon me the importance of drafting a time schedule for the duration of my PhD. More importantly, he taught me that in order to be able to bring to fruition such a long-term project as a $\mathrm{PhD}$ research one needs to restrict oneself to a very specific area of study. As Goethe put it, "in der Beschränkung zeigt sich erst der Meister," and though it took me a while to find out what the heart of my dissertation would be, everything fell into place once I had made that clear for myself. Our collaboration, furthermore, was always very pleasant. Thomas was ever willing to read and comment on my work and to provide helpful suggestions whenever I got stuck. In discussing my work, our common fondness for Kant functioned as a shared framework to which we could always refer in order to make ourselves understood to each other. It, furthermore, resulted in the translation of Kant's Über den Gemeinspruch, which we subsequently published: another very interesting and instructive experience. Finally, I thank Thomas for his unfailing support for my various undertakings: from spending a semester at the University of Pennsylvania, to getting my first article published, to providing advice when I was looking for a position post-PhD.

Sitting immediately to my right on that spring day was Ronald, my co-supervisor. His door was always open if I wanted to briefly discuss an idea or if I needed a book from his sizeable library. He, too, was always willing to provide elaborate commentaries on my work. His great attention to detail would eventually make me fear receiving his comments, as it generally meant I would have to do a lot of revising. Though I may not always have liked going through his notes, my work did unfailingly become better as a consequence.

Edith was seated immediately next to Ronald. Thanks to her, I learned a great deal very quickly about teaching. She was of great help when I had to teach my very first course together with her. She was always open for suggestions regarding the prescribed reading and the structure of the course, thus stimulating me to think about what I wanted to teach the students and how I wanted to bring it across. She encouraged me, furthermore, to present parts of the lectures, 
which was a wonderful, though at first somewhat daunting, experience. Thanks to her, my first experiences teaching were very pleasant ones.

To my left was seated Janneke. Having no background in law, and having to write a dissertation concerning human rights at a law department, it was essential for me to quickly become acquainted with human rights law. In this, Janneke was a great help. My very first chapter in particular required quite some knowledge of this field, and she was a brilliant source of relevant cases, books and articles. Furthermore, the human rights discussion group she organizes at the department was a perfect opportunity for me to quickly familiarize myself with the legal jargon. Finally, I would like to thank her for agreeing to preside over the manuscript committee. Thanks to her the whole process went very smoothly.

Next to these four people who interviewed me (and hired me - thanks for that as well!) over four years ago, I would like to thank everyone who made these four years at the "vaksectie" Philosophy of Law such a great experience, in particular Lonneke, Sylvie, Robert Jan, Sebastiaan and Peter. I would also like to thank all the members of our Kant reading group for all those wonderful mornings spent leisurely reading and discussing Kant (after four years we managed to wrestle our way through half of Die Metaphysik der Sitten!).

During the whole period of my PhD I was also part of a reading group in Amsterdam. I would like to thank Matthé, Jeroen and Arnold for their patience whenever I would redirect our discussion to whatever I was working on at the moment, for many enjoyable and informative evenings, and for being great friends.

About halfway through my PhD I spent a semester at the University of Pennsylvania. I am very grateful for the warm welcome I received from the Philosophy Department. From the very beginning I was involved in the various activities at the department, which made me feel right at home. The months I spent there constituted an extremely productive period, during which I clarified for myself the Kantian background of this dissertation, which is of such great importance for this work. I would specifically like to thank KC for agreeing to supervise me during my stay, for his helpful comments on my work and for allowing me to follow his course (a welcome variety from my work on Kant).

The members of my committee are owed a special thanks. Their helpful comments brought me to new insights and will allow me to further develop some of the themes of this dissertation in the future. The majority of the committee members have, furthermore, had to travel a considerable distance to be present at my defense, which I very much appreciate.

Turning to my family members, I would like to thank my brother Michael who, having already done his $\mathrm{PhD}$, provided me with much valuable advice re- 
garding the whole process, which often came in handy. I look forward to addressing each other exclusively as "Dr. Boot" from now on. My sister Nicole is always ready to lend me a hand, as most recently by helping me look for different job possibilities (thankfully that search is over). My mother taught me to love books and convinced me with her American optimism that you can do anything you put your mind to, and not to let anyone tell you different. I thank my father for all the practical advice he offered me during these past years of my first actual job.

My profound gratitude goes out to my wife Pina, for supporting me in all my endeavors, and for always being there. Whenever during these past four years I encountered a bump in the road, you would always help me get back on track. I don't know where I would be without you. Menomale che Pina c'è!!

Eleonora, my daughter, I thank you for coming into our lives, for your infectious joy and lust for life, and for reminding me that curiosity is a virtue. 



\section{LIST OF ABBREVIATIONS}

ACHPR

ACHR

ADRDM

CESCR

DHDR

DHSR

ECHR

ECOSOC

ECtHR

FRR

ICCPR

ICESCR

OAS

PACE

UDHR

UDHRe

UNHRC
African Charter on Human and Peoples' Rights

American Convention on Human Rights

American Declaration of the Rights and Duties of Man

Committee on Economic, Social and Cultural Rights

(Valencia) Declaration of Human Duties and Responsibilities

(Pre-draft) Declaration on Human Social Responsibilities

European Convention on Human Rights

United Nations Economic and Social Council

European Court of Human Rights

Fundamental Rights and Responsibilities

International Covenant on Civil and Political Rights

International Covenant on Economic, Social and Cultural Rights

Organization of American States

Parliamentary Assembly of the Council of Europe

Universal Declaration of Human Rights

Universal Declaration of Human Responsibilities

United Nations Human Rights Commission 



\section{INTRODUCTION}

Warum wird aber die Sittenlehre (Moral) gewöhnlich (namentlich vom Cicero) die Lehre von den Pflichten und nicht auch von den Rechten betitelt?

The Italian philosopher Norberto Bobbio rightly spoke of the primacy of rights in current political and legal discourse as a radical overturning of the millennia-old practice of considering moral philosophy's chief task to consist in the drafting of a catalog of duties, rather than of rights. ${ }^{2}$ From Moses's two tablets, to Cicero's De officiis, onto even Immanuel Kant - who viewed his Sittenlehre as a "doctrine of duties," ${ }^{3}$-, moral philosophy was believed to be a study of man's duties. Thus, the overarching question of Kant's second Critique is not "What are my rights?," but rather "What should I do?".

This traditional prevalence of duties over rights in moral philosophy, Bobbio goes on to say, was mirrored by the privileging of the viewpoint of the ruler over that of the ruled in political philosophy. Naturally, one also owed duties to one's fellow citizens - e.g., one ought to refrain from assaulting them and from stealing from them -, though often these were considered to be, in fact, duties to the sovereign. For instance, if one assaulted a fellow citizen, one did thereby not merely (perhaps not even especially) wrong him or her, but one also (or perhaps even especially) violated one's duty to the political community in general and therefore wronged the sovereign in particular, who is tasked, after all, with maintaining the laws and peace in the community. It is such a train of thought that lies at the foundation of Hobbes's statement that even the intention of breaking the law is not so much (or not merely) a sin against the potential victim of one's crime, but rather "the purpose to breake the Law, is some degree of Contempt of him, to whom it belongeth to see it executed," i.e. the sovereign. The performance of our duties was thus owed to the sovereign

1. Kant, I. (1907). Die Metaphysik der Sitten. In Kants Werke. Bd. 6: Die Religion innerhalb der Grenzen der bloßen Vernunft. Die Metaphysik der Sitten (pp. 203-493). Ausgabe der Königlich Preußischen Akademie der Wissenschaften. Berlin: Walter de Gruyter. 239.

2. Bobbio, N. (2009). Il primato dei diritti sui doveri. In M. Bovero (Ed.), Teoria Generale della Politica (pp. 431-440). Torino: Giulio Einaudi. 432.

3. Kant, I. (1996). The Metaphysics of Morals. In M. Gregor (Ed.), M. Gregor (Trans.), Practical Philosophy (pp. 363-603). Cambridge: Cambridge University Press. Ak 6:239.

4. Hobbes, T. (1996). Leviathan. (R. Tuck, Ed.) (Revised Student Edition). Cambridge: Cambridge University Press. Ch. 27, 201. 
and the political community as a whole, rather than to individuals as bearers of rights.

The importance of the gradual shift from duties to rights is thus clear: no longer would only the political community at large (and the sovereign at its head) enjoy the attention of our political and moral considerations; from this moment on, political and moral issues would also be viewed from the standpoint of the individual. The shift from duties to rights was thus also a movement away from the overarching whole and towards the individual as a bearer of rights. This shift, it seems, has been nearly complete in Western liberal democracies; political theory, public policy and moral philosophy are now predominantly concerned with the individual and her rights.

It is important to realize that the shift from duties to rights could not have taken place without a fundamental critique of the relation between the political community and the individual. Bobbio perceptively points out that the doctrine of natural or human rights presupposes an individualistic understanding of society and thus a rejection of the older, "organic" conception of society. ${ }^{5}$ The understanding of society as an organic whole can be found throughout the history of political philosophy: from Plato who compared the well-managed city "to the human body in its relation to the pleasure and pain of its parts," ${ }^{6}$ to Hobbes who viewed the commonwealth as an artificial man, ${ }^{7}$ to the continuing usage of such terms as "body politic" and "head of state" even today. The organic conception of society viewed the individual as subordinate to the political community. The individual's main importance resided in the contribution he or she could make to the political community. Therefore, justice, according to Plato, consists in each class of members in the community doing its own part and not meddling in the activities of others: the producers are not to interfere with matters of defense, and soldiers ought not to concern themselves with the affairs of state, which is the prerogative of the guardians. ${ }^{8}$ In the organic understanding of society each part of the whole has its own unique contribution to the wellbeing of the whole. So long as each part restricts itself to performing its assigned task, the whole will prosper. Yet, once, for example, the arms and legs attempt to decide for themselves in which direction they ought to move and refuse to accept the head's prerogative to control the body's movements, disorder steps in.

6. Plato. (1937). The Republic. (P. Shorey, Trans.). Cambridge, MA: Harvard University Press. Book V. 475. 
Individualism, which, as said, is of crucial importance for the birth of human rights, is thus, from the organic perspective, considered a potential threat and is therefore to be suppressed. Individuals are simply to serve the state in preassigned ways and make their peace with their fixed station in life. Individualism, by contrast, recognizes the unique value of every human being, as a being capable of making its own decisions and setting its own course. This recognition of what some would call human dignity lies as the basis of the birth of human rights. In order to ensure that each person can pursue her own goals and strive to achieve her own understanding of a fulfilled life, the state ought to secure a sphere of maximum reciprocal freedom for all. Individuals are understood to have a right to such freedom, a right which was initially, in the eighteenth century, understood to consist of rights to liberty, property, security and to resist oppression. ${ }^{9}$

The French Revolution was not solely an abolition of the monarchy; it also was a clear expression of the shift we have been speaking of. The individual assumed center stage. No longer was the individual but an instrument of the state; instead, the state was from then on considered to be legitimate only insofar as it heeded the individual. Thus, the French Declaration of 1789 clearly states in its second article that the "aim of all political association is the preservation of the natural and imprescriptible rights of man." It follows that any state unable or unwilling to preserve the rights of man is to be viewed as illegitimate.

This development was accelerated in the period following the Second World War, which was a period of steady expansion of the human rights discourse worldwide, to the point that many scholars have come to refer to it as the global moral lingua franca..$^{10}$ Indeed, the dominance of rights discourse in practical philosophy at times seems to be absolute, prompting certain scholars to speak of "rights infatuation." 11 Whereas prior to the shift from duties to rights, moral problems were analyzed solely in terms of duty (and perhaps of virtue), to the exclusion of rights, now it has become nearly impossible to speak about normative matters in a way that does not include rights. Even when we do speak of duties, these are considered to be derivative of rights, which has now become the most fundamental moral category. Today, it seems, rights are viewed as "most 
indicative of what morality is all about."12 The problem with such a rights-based approach to morality is thus not that it promotes rights - any case made for a renewed attention for duty in the pages of this dissertation does not in any way wish to detract anything from rights -, but rather that it ignores or disparages those spheres of human normative agency that cannot be framed in terms of rights, leading to an impoverishment of moral discourse. An example of such a neglected moral category, which will figure prominently in the pages to come, is that subset of our duties termed "duties of virtue." Given that rights are considered to be the most fundamental moral category, duties exist only to the extent that they stem from rights. It follows that duties of virtue, which do not have any correlative rights, tend to be neglected. ${ }^{13}$ As a consequence, it becomes difficult to convince persons that insisting on one's right may at times be the wrong thing to do. After all, from within a rights-dominated discourse it seems perfectly reasonable to think that so long as one does not violate the rights of others, one can do no wrong. ${ }^{14}$ To illustrate this point, consider the town Joel Feinberg dubbed Nowheresville II. ${ }^{15}$ In this town "everyone always insists upon his own rights against others: [...] debtors are never forgiven their debts, wrongdoers pardoned, gratuitous gifts conferred, or sacrifices voluntarily made, so long as it is within one's rights to refuse to do any of these things." 16 The first problem with the predominance of human rights in normative discourse is, therefore, that it leads to the neglect of those duties that lack corresponding rights, which in turn can lead to the heedless insistence on one's rights at all times and thus to an understanding of freedom as license.

12. Ibid. 89. Similarly, Henry Shue argues that "[b]asic rights are the morality of the depths" (Shue, H. (1980). Basic Rights: Subsistence, Affluence, and U.S. Foreign Policy. Princeton: Princeton University Press. 18). Cf.

13. Onora O'Neill especially has made this point most forcefully. See, e.g., O’Neill, O. (1996). Towards Justice and Virtue: A Constructive Account of Practical Reasoning. Cambridge: Cambridge University Press. Chapter 5.

14. In fact, it has been quite common for decades now to speak of "a right to do wrong." According to this position, I have a right to spend my lottery millions entirely on fancy shoes and bottles of Cristal, instead of donating some of my winnings to the destitute. I also have a right to found an openly racist party. As a supporter of a particular political party, I have a right to trick people, by providing them false information, into voting for that party. Instead of merely maintaining that we ought to tolerate such behavior, as interference in such cases by means of, for example, the penal code might be counterproductive and perhaps an example of government overreach, many a liberal scholar will argue we in fact have a right to perform immoral acts. Moreover, they view the right to do wrong as essential to the very idea of rights. See, for example: Waldron, J. (1981). A Right to Do Wrong. Ethics, 92(1), 21-39. I will briefly return to this matter (of a right to do wrong) in Chapter 2.

15. Feinberg, J. (1980). The Nature and Value of Rights. In Rights, Justice, and the Bounds of Liberty: Essays in Social Philosophy (pp. 143-158). Princeton: Princeton University Press. 156ff. The first, and more famous, Nowheresville is introduced at the beginning of Feinberg's article. Nowheresville I is a place much like our own, but for one important difference: no one has any rights.

16. Ibid. 156. 
An additional problem with the rights-based perspective on morality is the tendency to speak of human rights without also considering the duties involved, resulting in the promulgation of a plethora of human rights without much attention for the corresponding duties. The detrimental consequence of this disregard for duties is the oft-noted and oft-bemoaned inflation of human rights. The popularity of human rights discourse has led to "an unruly proliferation of incompatible or often just incredible rights claims," ${ }^{17}$ which damages the credibility of human rights discourse as such.

Given these two serious problems with what I will call the perspective of rights - whereby one starts by identifying rights independently of duties and from there proceeds to define the corresponding duties - the main thesis of the present study is that we ought to adopt instead a perspective of duties, whereby one starts from duties and from there proceeds to identify our rights (if, indeed, the duty in question involves corresponding rights). This shift of perspective, as will be elaborately argued and demonstrated in the following chapters, will, firstly, allow us to recognize the full scope of human duties (instead of focusing solely on rights-corresponding duties) - thus enriching our moral landscape - as well as, secondly, neatly clarify the content of those duties and allocate them to specific duty-bearers, which will bring to a halt the great proliferation of dubious human rights claims. The goal of this work is, in other words, firstly to salvage those duties that are often neglected due to the dominance of the perspective of rights - namely duties of virtue - and to argue for their importance, and secondly to counter the trend of rights proliferation by providing some conceptual clarity concerning rights and duties that will enable us to differentiate between genuine and spurious claims to the status of "right."

Concerns with the dominance of human rights discourse, such as those discussed above, eventually led to some pushback. In the realm of human rights discourse itself, this discontent was expressed chiefly in the form of various human duties declarations (such as the Universal Declaration of Human Responsibilities), which saw the light in the past two decades. The drafters of these human duties declarations argue for the necessity of a renewed focus on our duties, for which they offer several reasons. They argue, for example, that especially Western liberal democracies overemphasize individual rights and personal freedom, at the cost of our duties and of an understanding of freedom as involving 
necessarily a sense of responsibility. This imbalance between rights and duties, between freedom and responsibility, results, they maintain, in an unbridled individualism which could lead to conflict and discord. Furthermore, several of these declarations argue that rights need to be supported by morality if they are to be secured. Accordingly, the drafters seem to argue for the development of a particular moral disposition, which one might call civic virtue, or perhaps even cosmopolitan virtue.

These human duties declarations have not exactly received a warm welcome from human rights scholars. In general, the critics argue that such declarations are either superfluous, as human rights documents already make ample mention of rights-based duties, or, insofar as the human duties declarations contain duties that go beyond rights-based duties, they are dangerous. This debate between the drafters of the various human duties declarations and their critics will be discussed in Chapter 1. This chapter will, furthermore, provide an overview of the individual duties (that is, not the duties of states or corporations, but of individuals) present in the major human rights documents. This discussion will culminate in the selection of two individual duties that are particularly contentious, namely duties to the community (which can be found in Article 29 of the Universal Declaration of Human Rights (UDHR), but also, for example, in the African Charter on Human and People's Rights) and duties of aid to the global poor (which can be understood to correlate with the human right to an adequate standard of living stated in, e.g., Article 25 UDHR and Article 11 of the International Covenant on Economic, Social and Cultural Rights). These two duties will function as case studies in chapters 3, 4 and 5, as will be clarified in a moment.

Though this study thus starts with a discussion of the human duties declarations and the criticism they have received, it must be stressed that the goal of the present study is not to mount a defense of these declarations. The discussion of political and juridical documents - that is, the human duties and human rights documents - is not the main concern of this study. Rather, the proclamations of human duties declarations as well as the ensuing debate concerning their desirability will serve as a springboard for reflections on the importance of a renewed focus on duties, the relation between rights and duties, the categorization of duties (perfect and imperfect duties, duties of justice and duties of virtue) and the relation between justice and virtue.

Accordingly, Chapter 2 will start by clarifying the central terms: rights, duties, justice and virtue. Furthermore, this chapter will elucidate the relation between rights and duties as well as argue that perfect duties of justice (that is, duties with corresponding rights) are not, as is so often erroneously held, more 
binding or of greater importance than imperfect duties of virtue (that is, duties without corresponding rights). Finally, the case will be made for a duties-based perspective on morality instead of the by far more common rights-based perspective. In doing so, I will have to defend myself against critics who fear that a renewed focus on duties will necessarily be detrimental to our rights. I will, therefore, need to explain that a renewed attention for duties does not at all amount to, say, surrendering our rights and freedom to state power. On the contrary, rather than weakening or endangering human rights, a renewed emphasis on our duties will prove to strengthen human rights, particularly by preventing the proliferation of unclaimable rights. Starting from duties rather than rights, furthermore, will enable us to recognize the importance of duties of virtue, to which the perspective of rights must remain blind as the duties it recognizes are limited to rights-based duties, that is, duties of justice. Such duties of virtue, as will be made clear in Chapters 4 and 5, are of crucial importance as complements to the sphere of justice.

It bears mentioning that the exposition of the fundamental concepts provided in Chapter 2 is distinctly Kantian in nature. The nature of rights and duties, the distinctions between the various types of duties as well as the duties-based perspective on morality all find their origin in the work of Immanuel Kant, whereby I chiefly (but not solely) rely on his "Spätwerk" The Metaphysics of Morals. Kant's work is chosen for several reasons, of which I will mention two here. Firstly, it is important to point out that though Kant's writings (specifically, a certain reading of his concept of human dignity) are often considered to be one of the fonts of inspiration for the human rights movement, the book in which he speaks most of rights was actually viewed by Kant himself as a "general doctrine of duties." 18 Therefore, though we may imagine Kant to have supported the idea of human rights, he would also be very critical of the contemporary human rights discourse, as its neglect of duties fails to adequately identify rights and its rights-based perspective on morality prohibits it from appreciating the importance of duties of virtue. Secondly, the distinction Kant draws between types of duties - that is, between duties with corresponding rights (duties of justice) and duties without corresponding rights (duties of virtue) - as well as his understanding of a right as the ability to place others under obligations, allows us to provide some clarity in the jungle of rights claims by enabling us to distinguish genuine from spurious human rights. Chapter 2, in short, provides a theory of 
duties and rights, which will allow us to resolve practical problems from the fields of human rights law and politics in the remaining three chapters, particularly Chapters 4 and 5, which will discuss the two contentious duties singled out in Chapter 1. The discussion of these two case studies is meant to illustrate the advantages of the perspective of duties.

To begin, Chapter 3 will examine what we can learn from human rights documents and human duties declarations regarding the nature of the duties correlative to the human right to an adequate standard of living and the duties to the community. Regarding the former, we will find that such documents do not at all sufficiently clarify the nature of individual duties concerning global subsistence needs. Chapter 4 will, therefore, provide such clarity by asking, firstly, who has what duties in fulfilling subsistence needs, secondly what the status of such duties is (are they duties of justice or duties of virtue?), and thirdly, whether subsistence needs do indeed give rise to a human right to subsistence. It is in this manner that Chapter 4 demonstrates how starting from duties can allow us to discriminate more precisely between genuine and (as yet) spurious rights.

Regarding the duties to the community, by contrast, the study of the relevant human rights documents - particularly the travaux préparatoires of the Universal Declaration - will prove far more fruitful. Still, many deem such duties owed by the individual to the community to constitute a threat to rights. In fact, it is these duties that are most often denounced by critics of the human duties declarations (as well as of certain human rights documents, such as the African Charter, which also mentions duties to the community, in its Articles 27, 28 and 29). Therefore, Chapter 5 will illustrate that far from constituting a threat to our human rights, duties to the community are paramount to the preservation of a democratic political community, which, in turn, is instrumental in safeguarding our rights.

Finally, Chapter 5 will also discuss the claim of several human duties declarations that rights without morality cannot long endure; what is needed, the drafters of such declarations claim, is "voluntary self-obligation." ${ }^{19}$ Even legal rights that can be coercively enforced will be more reliably secured if all respect such rights willingly, rather than merely for prudential reasons. The present study is in agreement with such statements and will, in Chapter 5, provide arguments illustrating why calls for a virtuous disposition need not serve a hidden 
paternalistic agenda, provided they are limited to appeals for civic rather than personal virtue.

Chapter 5 thus provides us with an illustration of the importance of (duties of) virtue as complement to the sphere of justice. As such, it also demonstrates the desirability of the perspective of duties, for it can recognize such ethical duties to the community, whereas the perspective of rights can at best view them as optional excellences.

In his text Private Philanthropy and Positive Rights, Alan Gewirth presents us with a typical expression of the rights-based perspective on morality, whereby rights are taken to be the fundamental moral category: "the concept of rights," he writes, "and especially of human rights, is central and indeed indispensable to the whole field of morality." ${ }^{20}$ Instead, the present study wishes to argue for the importance of the adoption of a duties-based perspective on morality. Human rights are without a doubt of indispensable importance, yet the exclusive focus on rights has led to too narrow a view of morality. Starting from rights diminishes or often even entirely neglects the value of those duties that lack corresponding rights, in effect relegating the whole spectrum of duties of virtue to the sphere of the supererogatory. However, the sphere of justice - that is, the sphere of institutions and laws that are to secure our rights and enforce the corresponding duties - can greatly benefit from a population that regularly performs duties of virtue, which can thus function as a complement to the sphere of justice. Similarly, just laws and institutions can greatly benefit from widespread civic virtue, as such virtue can provide them with stability. It thus becomes apparent that an appeal for the importance of duties seems to involve a correlative claim concerning the importance of virtue as well as a claim concerning the interdependence between justice and virtue.

If the adoption of the perspective of duties has these apparent advantages, why then does any argument for a renewed emphasis on our duties generate such fierce criticism? There are sundry reasons, of which I will mention some here. Historically, as Bobbio has shown, the emphasis on duties went hand in hand with the neglect of rights and with the subordination of the individual to the state and the community. Given this problematic history, and the great moral progress realized by the shift to rights illustrated above, it is understandable that the call for a renewed focus on duties should occasion suspicion. Furthermore, 
as Onora O’Neill has pointed out, appeals to human duties have less “immediate charm" than human rights; a list of entitlements is more appealing than a list of obligations. ${ }^{21}$ Finally, especially the concept of "duties to the community" has caused fears that (some of) the human duties declarations aim to reintroduce a certain "holistic" notion of community in which the individual is reduced to an instrument of the whole (i.e. the political community), to a mere cog in the machine, as it were. These suspicions are fueled by the fact that such politicians as Lee Kuan Yew signed one of the major human duties declarations (namely, the Universal Declaration of Human Responsibilities). This former prime minister of Singapore was also a driving force behind the so-called Asian values movement in the 1990s, whereby the term "Asian values" was used in opposition to Western notions of individual freedom and human rights. Instead, the proponents of Asian values propagated the precedence of the harmonious development of the society as a whole over the freedom of the individual.

There are thus various legitimate reasons why many people experience some unease at the thought of the promulgation of human duties declarations or the suggestion that a duties-based perspective on morality is to be preferred over a rights-based morality. Therefore, I will need to be aware of the mentioned concerns and demonstrate that my argument does not detract anything from the importance and the force of rights. It will be necessary to distance my position from positions that are hostile to or even overly critical of rights. One of the main tasks set before me is thus to make the call for duties and the argument for a duties-based perspective on morality seem more appealing, and to convince the reader that far from endangering rights and threatening justice, a renewed emphasis on our duties will in fact strengthen and clarify human rights discourse as well as retrieve the importance of (duties of) virtue, which is of great moral significance in its own right, but also serves as an indispensable complement to the sphere of justice. A renewed emphasis on our duties will thus, ultimately, benefit our rights as well. 



\section{CHAPTER 1 \\ THE DEBATE CONCERNING HUMAN DUTIES}

\section{Quid leges sine moribus vanae proficiunt? ${ }^{1}$}

During the past two decades we have witnessed an ongoing discussion concerning individual human duties. Proponents of such human duties have explained their position in several declarations, in which they argue that current human rights law is characterized by an overemphasis on rights and personal liberty, resulting in an unbridled individualism, which a renewed focus on individual duty is meant to remedy. In order to gain an overall idea of these human duties declarations and the manner in which they differ both from each other and from current human rights documents, ${ }^{2}$ this chapter will start by providing an overview of the most important human duties declarations of the past twenty years. Subsequently, $\$ 1.2$ and $\S 1.3$ will provide an exposition of the critique leveled at these declarations by human rights scholars. The discussion of this debate between proponents and opponents of human duties declarations will serve as an introduction to the overarching question of this dissertation, which concerns the desirability of a renewed emphasis on duties in our normative (including our legal) discourse.

Critics have two general objections against the human duties declarations: firstly, they argue that such human duties discourse is dangerous, because it aims, they fear, at limiting the scope of human rights; secondly, a separate declaration of human duties is considered to be superfluous, as current human rights law supposedly already grants ample attention to the individual duties implied by human rights. The first point of critique will be considered in $\$ 1.2$, whereas the accuracy of the latter claim will be assessed in $\$ 1.3$ by examining both negative and positive human duties in several human rights documents. The conclusion of the latter section will be that human rights documents and human rights law have clarified our negative human duties quite well, but that our individual positive duties remain grossly neglected. The important but murky duties of aid to the global poor as well as the contentious duties to the community especially

1. Horace. (2008). The Odes of Horace. (J. H. Kaimowitz, Trans.). Baltimore: Johns Hopkins University Press. Ode III.24. p.131: "What good are empty laws without morality?"

2. I use the general term "human rights documents" when referring to binding human rights conventions and non-binding human rights declarations together. Human rights documents do not include human duties declarations. 
remain unclear and will therefore need to be further examined (in Chapters 4 and 5 respectively). Finally, $\$ 1.4$ will recapitulate the most important conclusions of the chapter, as well as pave the way for Chapter 2.

\section{§ 1.1 - Human Duties Declarations: The Problem}

In this section I will trace the development of human duties declarations, starting in 1993 with the Declaration Toward a Global Ethic of the Parliament of the Worlds' Religions until the draft resolution Fundamental Rights and Responsibilities, drawn up by the Parliamentary Assembly of the Council of Europe (PACE) in 2011. Instead of simply enumerating the various duties proposed in these documents, I will pay attention to the goal of such declarations: what they hope to achieve.

In September 1993 the Parliament of the World's Religions drafted a Declaration Toward a Global Ethic. This organization strives to realize an interfaith dialog by engaging religious leaders from all over the world, in order to bring an end to discord among the various religions, and reach a consensus on certain fundamental precepts shared by all faiths. Their 1993 Declaration - mostly written by the Catholic theologian Hans Küng - was drawn up with the express goal of developing a global ethic, based on the shared precepts of the world's main religions, ultimately culminating in the "Golden Rule": what you do not wish done to yourself, do not do to others. Such a global ethic is urgently needed, so the drafters held, for the attainment of a better global order. Legal rights are an important part of achieving that better order, but will not suffice, for "rights without morality cannot long endure." 3 Accordingly, the drafters sketched a new global ethic based on four main principles, or "irrevocable directives": (1) "commitment to a culture of non-violence and respect for life," (2) "commitment to a culture of solidarity and a just economic order," (3) "commitment to a culture of tolerance and a life of truthfulness" and (4) "commitment to a culture of equal rights and partnership between men and women." "

Almost exactly four years later, in honor of the $50^{\text {th }}$ anniversary of the Universal Declaration of Human Rights (UDHR), the InterAction Council - an in- 
dependent international organization of former heads of state and government, such as Helmut Schmidt, Jimmy Carter, Andries van Agt and Giscard d'Estaing - presented their Universal Declaration of Human Responsibilities (UDHRe). Hans Küng again played a pivotal role in the formulation of the document, and with calls for a global ethic and an invocation of the Golden Rule the drafters clearly placed themselves in the same tradition as the drafters of the Declaration Toward a Global Ethic. The UDHRe, however, goes further; it wishes to complement the discourse of human rights with a renewed focus on human responsibilities. The necessity for such a project stems from the perceived imbalance between rights and duties, between freedom and responsibility. The express goal of the UDHRe is to complement human rights documents such as the Universal Declaration of Human Rights (UDHR) in order to remedy this imbalance and "move from the freedom of indifference to the freedom of involvement." This is deemed necessary, because the overemphasis on individual rights is thought to lead to conflict and discord. Contrary to an often-heard critique (which we will discuss in \$1.2), the responsibilities enumerated in the UDHRe are not to be understood as legal obligations, but rather as moral obligations. The Declaration is meant, just as the UDHR, as a moral appeal and has "voluntary self-obligation" as its main aim. ${ }^{6}$ In the drafters' view, such voluntary self-obligation is necessary for the effective realization of human rights, which according to Hans Küng cannot only depend on legal coercion, but instead depends on the normative motivation of citizens themselves. In order to achieve such normative motivation, the Inter-Action Council has drafted their Declaration, containing such responsibilities as the responsibility to respect life (Article 5), the responsibility to contribute to overcoming poverty and inequality (Article 9) and the responsibility to use the right to freedom of expression in a responsible manner (Article 14).

In the following year, in 1998, the (Valencia) Declaration of Human Duties and Responsibilities (DHDR) was drafted under the auspices of the UNESCO, once again on the occasion of the $50^{\text {th }}$ anniversary of the UDHR. The renowned South-African judge Richard J. Goldstone chaired the high-level group responsible for the Declaration, consisting of experts from various fields, such as the arts (Dario Fo), international law (Richard A. Falk, Baltasar Garzón), politics (Ruud Lubbers), and philosophy (Michel Serres, Gianni Vattimo). The Declaration argues

5. InterAction Council. A Universal Declaration of Human Responsibilities. (1997, September 1). Retrieved from http://interactioncouncil.org/universal-declaration-human-responsibilities. Introductory comment.

6. Küng. Human Responsibilities Reinforce Human Rights. 168. 
that the effective realization of human rights "is inextricably linked to the assumption of the duties and responsibilities implicit in those rights" 7 and subsequently goes on to enumerate in great detail a wide variety of duties and responsibilities.

There are three main differences between this Declaration and the UDHRe. Firstly, the UDHRe only speaks of moral duties, whereas the DHDR distinguishes moral from legal duties. ${ }^{8}$ The Valencia Declaration thus wishes to function both as a moral appeal, and as an account of citizens' enforceable legal duties concerning human rights. Secondly, the DHDR does not, contrary to the UDHRe, only discuss individual duties, but also considers the duties of states and, in fact, reaffirms that states exercise the primary duty regarding the protection and realization of human rights. Thirdly, contrary to the UDHRe, its goal in drafting this list of duties and responsibilities is not to remedy an imbalance between rights and duties; it recognizes no such imbalance and appears quite content with the current relation between rights and duties. Instead, the DHDR aims simply to underline the duties and responsibilities that correlate with human rights in order to achieve more respect for and better protection of human rights worldwide. Perhaps due to these three differences, the DHDR has suffered much less criticism than the UDHRe.

In 2000, the UN Human Rights Commission asked the Sub-Commission on the Promotion and Protection of Human Rights to research the relation between human rights and human responsibilities. This initial resolution was passed with the smallest possible majority ( 22 in favor -21 opposed -10 abstentions). ${ }^{9}$ The research on the interrelation between rights and responsibilities, headed by Special Rapporteur Miguel Alfonso Martínez, resulted in the 2003 pre-draft Declaration on Human Social Responsibilities (DHSR). Later that same year, the Commission was unable to pass a proposal to have Martínez send the draft declaration to member states and NGOs $(25-25-3) .{ }^{10}$ In 2004, the same proposal was accepted by a difference of merely one vote. ${ }^{11}$ During it last full meeting in 2005, before being replaced by the Human Rights Council in 2006, the Com-

7. Valencia Third Millennium Foundation. Declaration of Human Duties and Responsibilities. (1998). Retrieved from http://globalization.icaap.org/content/v2.2/declare.html. Preamble.

8. From this point on I will use the terms "moral duty" and "legal duty" in this chapter, though the precise explanation of the difference between the two will have to wait until the next chapter (from which point onward I will mostly use the more precise terms "duty of virtue" and "duty of justice"). The various declarations use different terms - such as "responsibility," "duty" and "obligation" - to refer to the same thing, which only results in confusion. For this reason, I will largely limit myself to using the term "duty" alone.

9. United Nations Commission on Human Rights (UNCHR). Report on the Fifty-Sixth Session. UN Doc. E/CN.4/2000.167. Resolution 2000/63. 276-7.

10. UNCHR. Report on the Fifty-Ninth Session. UN Doc. E/CN.4/2003.135. 433-4.

11. UNCHR. Report on the Sixtieth Session. UN Doc. E/CN.4/2004/127. 346. 
mission asked Martínez to draft a new version of the Declaration. This request, however, was blocked by the UN Economic and Social Council (ECOSOC). The Human Rights Commission thus never accepted the draft Declaration and the Human Rights Council has not yet considered it.

In the next section we will explain why so many opposed this draft declaration, but for now a brief description of the document will suffice. In the final report accompanying the draft declaration, Martínez acknowledged to have been influenced by the InterAction Council's UDHRe. ${ }^{12}$ In fact, there are many similarities between the two declarations to be found. For instance, Martínez stated that the responsibilities enumerated in the draft declaration are not legal duties, but rather stem from social ethics and human solidarity. At the same time, however, the express goal of the draft declaration is to be adopted as an international standard of human responsibilities by the UN, similar to the UDHR. As we will see, this ambiguity with regard to the legal status of the document is one of the main sources of concern for its critics.

Perhaps attempting to assuage his critics, Martínez repeatedly emphasized that, as rights and duties depend upon one another for their full realization, a renewed emphasis on human duties would only strengthen human rights, not weaken them. In this context, he called for the development of a global ethic, which was to strengthen international human rights law, ${ }^{13}$ a clear echo of Hans Küng's argument that legal rights alone cannot ensure a rightful condition and that therefore a global ethic is needed to attain voluntary self-obligation.

Finally, the draft declaration is also meant as a corrective to what is viewed as the unbridled individualism of the West and is opposed to the "culture' of 'Individual rights, YES! Social responsibilities, NO!'”14 It holds that, when individual rights are allowed to predominate over those of society as a whole, and individual duties are neglected, freedom will be endangered and conflict will be the result. Accordingly, the majority of the duties recognized by the DHSR are duties of the individual towards other individuals and to society as a whole. The list contains negative duties of respect for the rights of others, but also duties to respect the security of the society in which one lives as well as the morality prevalent in it (Article 12), and positive duties to develop one's talents (Article 25) and to preserve the positive elements of one's cultural heritage (Article 23).

12. UNCHR. Promotion and Protection of Human Rights: Human Rights and Human Responsibilities. UN Doc. E/CN.4/2003/105. (2003, March 17). Retrieved from http://daccess-dds-ny.un.org/doc/UNDOC/ GEN/G03/120/23/PDF/G0312023.pdf?OpenElement 16.

13. UNCHR. Human Rights and Human Responsibilities. 20.

14. Ibid. 12. 
The most recent document in the ongoing discussion concerning human duties is a product of the Parliamentary Assembly of the Council of Europe (PACE). On 25 November 2011 the draft resolution on Fundamental Rights and Responsibilities (FRR) ${ }^{15}$ was adopted by the Standing Committee, acting on behalf of the PACE. The document posits a distinction between moral and legal duties, whereby it argues that legal duties must be subject to the proportionality principle (i.e. they may not be too heavy a burden) and that moral duties may not be so burdensome that bearing them would endanger the individual's fundamental rights. The FRR thus constitutes an account of human duties that, despite its numerous references to the UDHRe and the DHSR, is in fact more similar to the DHDR. Like this latter declaration, it recognizes the necessity for human duties, but is extremely careful not to let them bring human rights into peril.

Though the explanatory memorandum accompanying the list of duties posits a distinction between moral and legal duties, the actual list contains only "responsibilities," which are understood as moral duties. Thus, even such duties as the duty to respect the human rights of others, to respect life, and to respect non-discrimination are to be viewed as mere moral duties. The final clause of the document, however, does discuss the possible conversion into legally enforceable duties, but is limited to repeating the general comments that legal duties may not be too demanding and must not conflict with citizens' fundamental rights.

Thus, within the scope of a few years, multiple declarations ${ }^{16}$ emphasizing the need for a renewed focus on duties saw the light. We can divide these declarations into roughly two categories. In the first category we find declarations such as the DHDR and the FRR. These declarations recognize the interdependence of rights and duties and strive to clarify the relation between the two. They are careful, however, to distinguish between legal and moral duties, so that our legal

15. Parliamentary Assembly of the Council of Europe (PACE). Fundamental Rights and Responsibilities. Doc. 12777. (2011, October 24). Retrieved from http://assembly.coe.int/nw/xml/XRef/Xref-XML2HTML-en.asp?fileid=12965\&lang=EN.

16. This list is by no means complete. One could also mention the International Council of Human Duties (1993), initiated by Prof. Rita Levi Montalcini, the Declaration on the Right and Responsibility of Individuals, Groups and Organs of Society to Promote and Protect Universally Recognized Human Rights and Fundamental Freedoms (adopted by the UN General Assembly in 1998), and the Earth Charter (2000). In the Netherlands, the so-called "Nationale Conventie" in 2005 was a similar initiative. It contained proposals to require citizens to contribute to the common good and suggested that 17-year-olds do a "social" internship (in community centers, nursing homes, refugee care, etc.): Nationale Conventie. Hart voor de publieke zaak. (2006, September). Retrieved from http://www.parlement. com/9291000/d/natconv.pdf. In the UK the government drafted a green paper entitled Rights and Responsibilities: Developing Our Constitutional Framework. (2009, March). Retrieved from https://www. gov.uk/government/uploads/system/uploads/attachment_data/file/228938/7577.pdf. 
duties do not become too burdensome, in which case our fundamental rights might be brought into jeopardy. Their main goal in allocating human duties is to preserve our current human rights culture.

In the second category, we find declarations such as the UDHRe and the DHSR that set a very different goal. The idea common to these declarations is that today we are confronted with an overemphasis on individual rights. A renewed focus on human duties is to counter this development and bring freedom and responsibility more into balance with each other in order to move "from the freedom of indifference to the freedom of involvement." The drafters of these documents hold, in sum, that by focusing exclusively on individual rights we stimulate an idea of citizenship that is not concerned with the effects of the free exercise of one's rights on the rest of the community. A renewed focus on duties is to remedy this ailment.

The difference between these two types of declarations brings us directly into some of the main themes of the present dissertation: the importance of a renewed focus on duties, the ideal relation between rights and duties, the categorization of duties (into legal and moral duties, or duties of justice and duties of virtue), and the ideal relation between law and morality, or justice and virtue, in general. These themes will be discussed throughout the dissertation from different perspectives. The next section will present a first attempt at grappling with these questions by providing an overview of the reactions of human rights scholars to the promulgation of the various human duties declarations. We will see that their concerns are chiefly aimed at the ambiguity of the status of the proposed duties (are they legal or moral duties?) as well as at the perceived threat that governments will turn to legislating morality (i.e. the worry of paternalism).

\section{$\S 1.2$ - Critique of Human Duties Declarations}

Despite their lofty aims of creating a global ethic and more responsible citizens so that human rights may be better protected and fully realized, human duties declarations of the second category, especially the UDHRe and the DHSR, have been greeted with overwhelming critique and skepticism. The two main points of criticism can be summed up as follows: "überflüssig und gefährlich."17 This section 
will deal with the last point, leaving the first point for $\S 1.3$. Five points of critique will be discussed: the indeterminate nature of the duties listed in the human duties declarations, their unclear status (are they legal or moral duties?), the threat of paternalism, the support from repressive regimes, and the fear that the performance of human duties will become a precondition for the enjoyment of human rights.

1. The indeterminate nature of duties. In his article entitled "Horizontal Human Rights Law” John Knox distinguishes two categories of duties: converse duties and correlative duties. ${ }^{18}$ The former are vertical duties that run conversely to the duties of the state to respect, protect and fulfill human rights. They are thus duties owed by individual citizens to the state or to society at large. Such duties, he maintains, "have the potential to undermine human rights because the government may rely on them to offset the duties it owes to the individual under human rights law." ${ }^{19}$ Correlative duties, on the other hand, are individual duties owed to fellow citizens to respect their rights and are therefore truly horizontal duties. Contrary to converse duties, correlative duties can, Knox maintains, in fact contribute to the protection of human rights. For example, the right to life would be of little consequence if it did not give rise to the correlative duty to not take an innocent life, a duty shared by all. Knox's critique of the DHSR starts from his observation that it contains mostly converse duties to society. These are vertical duties owed by the individual to the state or society, such as the "duty to behave in a fraternal manner toward others." ${ }^{20}$ The problem with such duties is that, given that they are not directly connected to a particular right, it remains unclear when one has fulfilled one's duty. As a consequence, such duties could be extended in ways that conflict with the protection of human rights. For exam-

18. It must be noted here that Knox's distinction is used only provisionally at this point, in order to provide a first approach to the great variety of duties discussed in this chapter. Yet, as will become apparent further on in the chapter, his distinction will not suffice to neatly distinguish between legal and moral duties. For this reason, it will be necessary to undertake in the next chapter a careful exposition of the grounds on the basis of which one can separate the two sets of duties from one another.

19. Knox, J. H. (2008). Horizontal Human Rights Law. American Society of International Law, 102(1), 1-47. 2.

20. UNCHR. Human Rights and Human Responsibilities. Article 14. Knox fails to mention, however, that Article 1 of the Universal Declaration contains almost precisely the same duty (though it does not use the word "duty"): "All human beings are born free and equal in dignity and rights. They are endowed with reason and conscience and should act towards one another in a spirit of brotherhood" (emphasis added). 
ple, Article 29(4) of the African Charter on Human and Peoples' Rights $^{21}$ - a document often criticized for its inclusion of human duties - contains the duty "[t]o preserve and strengthen social and national solidarity, particularly when the latter is threatened." It is not clear to what right this duty could correspond, and it should therefore be viewed as a converse duty to society as a whole. The scope of this duty, furthermore, remains unclear: can the duty to preserve national solidarity be extended in such a manner as to justify the silencing of voices of dissent? When a duty does not correspond to a particular right, it remains difficult to answer such questions, Knox maintains. The limits of converse duties are vague and thus, when they acquire the force of law, possibly open to manipulation by those who wish to limit the ambit of human rights.

2. The unclear status of duties. Proponents of these declarations of human duties would argue that their critics who fear that such duties will be abused by repressive governments misunderstand the status of the human duties expounded in such declarations. They would emphasize the fact that the individual duties enumerated in the DHSR and the UDHRe are explicitly intended as moral (not as legal) duties. Yet, critics seem to find this argument unconvincing. They point out that the human duties declarations are nonetheless written in the same language and style as, for instance, the UDHR. ${ }^{22}$ Moreover, both the InterAction Council and the drafters of the DHSR have stated that they wish their respective declarations to have a similar status as the UDHR. ${ }^{23}$ While it is true that the UDHR is, strictly speaking, not legally binding either, it has resulted in binding treaties (most notably the International Covenant on Civil and Political Rights). Furthermore, some commentators even

21. African Charter on Human and Peoples' Rights, hereinafter ACHPR (adopted on June 271981 and in force since October 21 1986).

22. Knox. Horizontal Human Rights Law. 33.

23. Fraser, M. (2005). Human Responsibilities and Human Rights in the Age of Terrorism. High Level Expert Group Meeting on Human Rights and Human Responsibilities in the Age of Terrorism. April 1-2. Santa Clara University. http://www.scu.edu/ethics/practicing/focusareas/global_ethics/laughlin-lectures/ rights-responsibility-fraser.html: "It had been our hope that the Draft Declaration [of the UDHRe] would be introduced into the United Nations to be a companion piece to the Universal Declaration of Human Rights so that both 'rights' and 'responsibilities' would be defined." Similarly, the DHSR repeatedly expresses the wish to become an international standard regarding the social responsibilities of individuals. 
regard the UDHR as customary international law. ${ }^{24}$ Due to these facts, it remains unclear what status the duties listed in the DHSR and the UDHRe are meant to have. It is this ambiguity with regard to the status of these duties that disquiets human rights advocates.

3. The threat of paternalism. Closely connected with this unclear status of human duties, is the question concerning the desirability of a "global ethic." Both the UDHRe and the DHSR argue that a better social order cannot be achieved by laws alone, and that therefore a global ethic is required. Critics have responded to this proposal by arguing that "codifying responsibilities may intrude arbitrarily and selectively into delicate codes of local human morality." 25 They worry that the introduction of such a global ethic will demand of citizens not only that they abide by the law, but also that they be good. In other words, they fear that it would enable the state to interfere with citizens' morality, or virtue. If it were beyond any doubt that these human duties declarations were intended as inspirational documents alone, then such appeals for moral conduct would be quite harmless and perhaps even welcome. Yet, due to the ambiguity regarding the status of these declarations (discussed above), the danger of states abusing the call for a global ethic to enforce a particular mode of conduct they deem "moral" is thought to remain present. In essence, the fear is that such a global ethic might lead to paternalism: "if we accepted the ethical criterion it proposes, then freedom of speech cases would turn on the moral worth of what was being spoken. Freedom of assembly cases would turn on the moral worth of the protest, and so on." 26

4. Support from repressive regimes. An additional factor that worries critics of the human duties declarations stems from the list of supporters of these documents. Among the members of the InterAction Council, for instance, we find the former prime minister

24. Chinkin, C. (2010). Sources. In D. Moeckli, S. Shah, \& S. Sivakumaran (Eds.), International Human Rights Law (pp. 103-123). Oxford: Oxford University Press. 120.

25. Saul, B. (2001). In the Shadow of Human Rights: Human Duties, Obligations, and Responsibilities. Columbia Human Rights Law Review, 32, 565-624. 602.

26. Eleftheriadis, P. (2010). On Rights and Responsibilities. Public Law, 31, 33-45. 43. The author is here referring to the UK Government's green paper Rights and Responsibilities calling for a British Bill of Rights and Responsibilities. 
of Singapore Lee Kuan Yew (referred to by some as a "benevolent dictator"), who is not known as the greatest champion of human rights. Matters appear even worse for the DHSR. As said, in 2000 the initial resolution to study the relation between human rights and human responsibilities - which would eventually culminate in Martínez' final report and pre-draft Declaration - was passed by the UN Commission on Human Rights (UNCHR) with only the smallest possible majority (22-21, with ten abstentions). Among the countries in favor of the resolution were China, Cuba, Pakistan, Democratic Republic of the Congo, and Sudan. Freedom House's annual report on "Freedom in the World" places all these countries in the "not free" category, whereas the vast majority of the countries opposing the resolution belong to the "free" category. ${ }^{27}$ The fact that the Special Rapporteur Martínez was himself from a country well known for disregarding basic civil liberties and political rights (namely Cuba) did not help matters. The support from countries with authoritarian tendencies does indeed seem to be a deadly blow for the human duties movement. Even if the intentions of the DHSR are benevolent, it seems certain countries plan to abuse the concept of human duties to the detriment of human rights.

5. The performance of duties as precondition for enjoying rights. A final recurring point of criticism concerns the worry that a declaration of human duties would end up making human rights conditional upon the adequate exercise of one's duties. ${ }^{28}$ Thus, in 2004 (a year after the first presentation of the pre-draft Declaration) the European Union presented a statement to the UNCHR rejecting the pre-draft Declaration as a threat to human rights. The EU feared that a declaration of human responsibilities would introduce conditions for protecting human rights. ${ }^{29}$ In other words, the EU wished to prevent the possibility

27. Freedom House places countries in three different categories - "free," "partly free" and "not free" - according to their compliance (or lack thereof) with basic civil and political human rights. The 2014 report can be found at: https://freedomhouse.org/report/freedom-world/freedom-world-2014\#.VMkKFMYipII. Incidentally, the report does not place all of Pakistan in the not-free category, but only Pakistani Kashmir. The rest of Pakistan is placed in the partly free category.

28. E.g. Lazarus, Liora et al. The Relationship Between Rights and Responsibilities (December 12009 ). Ministry of Justice Research Paper No. 18/09. Retrieved from http://ssrn.com/abstract=2022270 or http:// dx.doi.org/10.2139/ssrn.2022270. 29-30; Eleftheriadis. On Rights and Responsibilities. 45.

29. United Nations Economic and Social Council. Statement on behalf of the European Union (July 22, 2004). PRES04-217 EN. http://eu-un.europa.eu/articles/en/article_3700_en.htm. 
of some states refusing a citizen his or her right to a fair trial, because he or she has not fulfilled his or her duty to obey the law, for example. Critics maintain that the UDHRe and DHSR do not exclude such conditionality clearly (enough) and therefore remain open to abuse.

These five points of criticism concern mainly the possible dangers connected with an imprecise use of human duties. Therefore, the following chapters (particularly Chapters 3 and 4) will set out to neatly define the content, scope and status of two particularly contentious positive duties, whereas Chapter 5 will deal with the question of paternalism. The larger point will be that it is possible to argue for human duties in a manner that is precise, discerning and, most importantly, compatible with and even beneficial to human rights.

First, however, we will discuss the second overarching point of criticism of human duties (the other being the danger involved), namely the argument that a separate declaration of human duties is superfluous. The drafters of the human duties declarations argue that the relevant documents of international human rights law promote an unchecked individualism without due regard for the duties owed to one's fellow man and one's (political) community. Yet, critics retort, human rights documents already acknowledge the need for duties that correspond to human rights. In order to establish the veracity of this last statement (and to see whether such rights-corresponding duties cover the entire gamut of duties put forward in human duties declarations) the next section will be dedicated to an examination of the individual duties already present in current human rights documents.

\section{$\S 1.3$ - Human Duties in International Human Rights Law}

This section does not aim to provide an exhaustive overview of all the individual duties present in international human rights law. Instead, the goal is to study some of the most important international human rights documents in order to clarify the role that individual duties play in them. Is there indeed already, as critics of the human duties declarations have stated, enough attention for human duties in international human rights documents? If so, how do those duties compare to those enumerated in, for instance, the UDHRe and the DHSR?

In order to answer these questions, this section is structured in the following manner: first, in $§ 1.3 .1$, we will discuss some of the negative individual duties (what Knox referred to as "correlative duties") - i.e. duties of non-inter- 
ference and duties to exercise one's rights responsibly - present in international human rights documents; subsequently, in $\$ 1.3 .2$, we will consider a number of positive individual duties ${ }^{30}$ that these documents contain. The conclusion will be that there is indeed more talk of individual duties in human rights documents than one would initially expect, but that the duties going beyond mere negative duties of forbearance and duties to exercise one's rights responsibly are not at all sufficiently clarified. Positive duties of aid and duties to the community are, instead, characterized by an astonishing vagueness, which belies the criticism found at the outset of this chapter that a renewed focus on individual duties, advocated by the drafters of the human duties declarations, would be superfluous.

\section{§ 1.3.1 - Negative Individual Human Duties in International Human Rights Law}

Though human rights were initially intended mainly as guarantees for the protection of certain fundamental freedoms and interests against the state, and the question of duties referred almost exclusively to state duties to "respect, protect and fulfill" human rights, the last years have witnessed an ever growing interest for the duties of non-state actors. The traditional vision in which the state alone is the bearer of human duties is thereby slowly being replaced by a more pluralist conception of human duties. Great steps have already been taken in defining the human duties of such non-state actors as transnational corporations, ${ }^{31}$ international financial institutions (such as the World Bank, the IMF and the WTO) ${ }^{32}$, NGOs, rebel groups, and the international community. ${ }^{33}$ Some have argued that the reason for this gradual change lies in the fact that, though states are obviously still responsible for a great part of human rights violations worldwide, "individuals and private groups, including corporations and terrorist bands, are now thought to pose an equal or greater threat to public order." ${ }^{34}$ The present

30. The reader will notice that I have dropped Knox's distinction between "correlative" and "converse" duties. Converse duties, as Knox defines them, refer solely to duties owed by the individual to the state or society at large. However, given that, in the rest of the dissertation, I will not only focus on such duties to the community, but also on individual duties of aid (which are certainly not vertical or converse duties, but rather horizontal duties that stem from global subsistence needs), I have chosen to use the term "positive duties" here instead, which can cover both duties to the community and duties of aid.

31. De Schutter, O. (2006). Transnational Corporations and Human Rights. Oxford: Hart Publishing.

32. Ibid.; Lafont, C. (2010). Accountability and Global Governance: Challenging the State-Centric Conception of Human Rights. Ethics and Global Politics, 3(3), 193-215.

33. For a good overview of the various human rights duties of non-state actors see: Clapham, A. (2006). Human Rights Obligations of Non-State Actors. Oxford: Oxford University Press.

34. Katz Cogan, J. (2011). The Regulatory Turn in International Law. Harvard International Law Journal, 52(2), 321-372. 330. 
dissertation focuses on individual human duties, because the central values and interests that lie at the foundation of human rights are of such a fundamental import that they merit protection not only from states and the non-state actors mentioned above, but also from possible violations by private persons. Accordingly, this subsection sets out to expound the various negative individual human duties present in international human rights law, whereby the main focus will lie on the European Convention on Human Rights ${ }^{35}$ and the International Covenant on Civil and Political Rights. ${ }^{36}$ Other human rights documents will be mentioned in a more cursory fashion.

Negative duties of respect for the human rights of others can again be divided into two classes: (1) duties of forbearance (duties to refrain from doing something) and (2) duties to exercise one's rights responsibly. As an example of an individual duty of forbearance we could examine the various duties correlating with the right to be free from slavery, servitude and compulsory labor (Article 4 ECHR, Article 8 ICCPR). Whereas the prohibition of compulsory labor is mainly aimed at states, the prohibition of slavery and servitude - given that slavery and servitude chiefly take place within the private sphere - indicates that this right was also meant to have a horizontal effect or Drittwirkung (third-party applicability), as it is termed in German legal discourse. Both documents simply state that no one is to be held in slavery or servitude, whereby it is irrelevant by whom one is enslaved. Therefore we may conclude that not only the vertical relations between the state and citizens, but also the horizontal relations between citizens among themselves are regulated by this human right. ${ }^{37}$ The individual human duty in this case thus consists in a duty of forbearance, i.e. a negative duty not to enslave or force into servitude anyone else.

International criminal law provides us with additional examples of such individual duties of forbearance. Thus the Convention on the Prevention and Punishment of the Crime of Genocide unequivocally states that "[p]ersons committing genocide ... shall be punished, whether they are . . public officials or private individuals." 38 Similarly the International Convention on the Suppression and Punishment of the Crime of Apartheid emphasizes that "apartheid and

35. The European Convention on Human Rights, hereinafter ECHR (drafted in 1950 and in force since 1953).

36. The International Covenant on Civil and Political Rights, hereinafter ICCPR (adopted in 1966 and in force since 1976).

37. Van Leuven, N. (2009). Contracten en mensenrechten: Een mensenrechtelijke lezing van het contractrecht. Antwerpen: Intersentia. 73.

38. Convention on the Prevention and Punishment of the Crime of Genocide (adopted by the UN General Assembly on 9 December 1948 and in force since 12 January 1951). Article 4. 
similar policies and practices of racial segregation and discrimination . . . are crimes violating the principles of international law," and that "[i]international criminal responsibility shall apply . . . to individuals," and not merely to representatives of state. ${ }^{39}$

The individual duties to exercise one's rights responsibly are more complex than the individual duties of forbearance, discussed above. As they are connected to the limitations that are placed on the exercise of certain human rights, they raise the question when such limitations are legitimate. The right to freedom of expression is a famous example of a right that may be subject to certain restrictions. Article 20 ICCPR, for example, states that any form of propaganda for war should be prohibited by law, as well as any advocacy for national, racial or religious hatred that constitutes incitement to discrimination, hostility or violence. Furthermore, Article 19(3) ICCPR explicitly states that the right to freedom of expression "carries with it special duties and responsibilities" and may therefore be subject to restrictions by the authorities in the case of a pressing social need, i.e. the rights or reputations of others, national security, public order, public health, and public morals. Article 10(2) ECHR is worded very similarly, ${ }^{40}$ with the exception that it allows for several more limitations in the interest of, for example, territorial integrity. The limitations that may be placed on the right to freedom of expression roughly coincide with those that may be applied to a number of other rights, such as the right to respect for private and family life (Article 8(2) ECHR), the right to freedom of thought, conscience and religion (Article 9(2) ECHR, Article 18(3) ICCPR), the right to freedom of assembly and association (Article 11(2) ECHR, Articles 21 and 22(2) ICCPR), and the right to liberty of movement (Article 2(3) of the Fourth Protocol to the ECHR, Article 12(3) ICCPR). ${ }^{41}$ Therefore the guidelines that will be expounded below in the context of the right to freedom of expression are by and large also applicable to these rights.

Despite the fact that both the ECHR and the ICCPR mention which public needs may legitimately warrant the restriction of the right, it may still prove very difficult to establish whether a particular restriction of freedom of expres-

39. International Convention on the Suppression and Punishment of the Crime of Apartheid (adopted by the UN General Assembly on 30 November 1973 and in force since July 18 1976). Articles I(1) and III. For a more elaborate discussion of individual human duties under international criminal law cf. Knox. Horizontal Human Rights Law. 27-30.

40. One thus wonders how Knox can possibly justify his claim that the ECHR "does not mention private duties at all:" Knox. Horizontal Human Rights Law. 14.

41. Martinez-Torron, J. (2003). The Permissible Scope of Legal Limitations on the Freedom of Religion or Belief: The European Convention on Human Rights. Global Jurist Advances, 3(2), 1-40. 2. 
sion is legitimate. For this reason, international law has developed a three-part test to determine whether a limitation is necessary: the limitation must be (1) prescribed by law, (2) necessary in a democratic society, and (3) proportionate or necessary to reach some of the aims itemized in, for example, Article 10(2) ECHR or Article 19(3) ICCPR. ${ }^{42}$ In other words, any restriction of the right to freedom of expression must be prescribed by law (and these laws must be publicly accessible); it must pursue a legitimate aim (such as the protection of the rights of others); and the harm caused by the limitation of the right must not outweigh the benefit gained in terms of protecting certain fundamental interests. With regard to this last point, the European Court of Human Rights has repeatedly made clear that the exceptions to which freedom of expression is subject under Article 10(2) "must be narrowly interpreted and the necessity for any restrictions must be convincingly established." ${ }^{3}$

Next to the limitations that are inherent to the very right itself (as stated in the second paragraphs of Articles 8, 9, 10 and 11 of the ECHR), the European Convention also contains Article 17, the so-called 'abuse clause.' This article consists in a general prohibition of the abuse of the rights listed in the Convention. ${ }^{44}$ Usually this article is used indirectly, that is, by applying it together with another article - Article 10(2), for example -, in order to decide whether or not a particular limitation (of freedom of expression, in our example) is legitimate. In certain cases, however, the abuse clause is used in a direct manner, "categorically excluding certain expressions from the protection of Article 10." 45 This last approach is particularly common when the Court has to deal with instances of hate speech that undermine the central values of the Convention itself by expressing racist, xenophobic, anti-Semitic, and aggressively nationalistic views, as well as views that are discriminatory towards minorities and immigrants. ${ }^{46}$ Thus in the case Pavel Ivanov v. Russia the Court held that Ivanov's anti-Semitic remarks

42. Ibid. 3 .

43. European Court of Human Rights (hereinafter ECtHR). Thorgeirson v. Iceland. 25 June 1992. Application No. 13778/88. Para. 63.s

44. "Nothing in this Convention may be interpreted as implying for any State, group or person any right to engage in any activity or perform any act aimed at the destruction of any of the rights and freedoms set forth herein or at their limitation to a greater extent than is provided for in the Convention." Similar 'abuse clauses' can be found in the UDHR (Articles 29(2), 29(3) and 30) and in the ICCPR and the ICESCR (common Article 5(1)).

45. Cannie, H., \& Voorhoof, D. (2011). The Abuse Clause and Freedom of Expression in the European Human Rights Convention: An Added Value for Democracy and Human Rights Protection? Netherlands Quarterly of Human Rights, 29(1), 54-83. 58.

46. Recommendation No. R 97 (20) of the Committee of Ministers of the Council of Europe on "hate speech" (adopted on 30 October 1997). Retrieved from http://www.coe.int/t/dghl/standardsetting/hrpolicy/other_committees/dh-lgbt_docs/CM_Rec(97)20_en.pdf. 
did not enjoy protection under Article 10: "Such a general and vehement attack on one ethnic group is in contradiction with the Convention's underlying values, notably tolerance, social peace and non-discrimination." ${ }^{47}$ Such direct applications of Article 17 are, however, not limited to expressions of anti-Semitism, as the Court showed in Norwood v. the United Kingdom. This case concerned a member of the British National Party who, by means of a poster in his window, equated Muslims with terrorists, prompting the Court to a similar judgment as in the Ivanov case:

Such a general, vehement attack against a religious group, linking the group as a whole with a grave act of terrorism, is incompatible with the values proclaimed and guaranteed by the Convention, notably tolerance, social peace and non-discrimination. ${ }^{48}$

In addition to the duties that are mentioned in Article 10(2) and the general prohibition of the abuse of rights in Article 17, the jurisprudence of the Court has shown that certain professionals (such as journalists) have special duties with regard to the exercise of their right to freedom of expression. The reason why the Court believes they have these special duties was given by the Grand Chamber in Stoll v. Switzerland:

Hence, the safeguard afforded by Article 10 to journalists in relation to reporting on issues of general interest is subject to the proviso that they are acting in good faith and on an accurate factual basis and provide "reliable and precise" information in accordance with the ethics of journalism . . ${ }^{49}$

This brief discussion of human rights documents clearly illustrates that their drafters were very aware of the fact that:

the legal implementation of human rights requires not only the correlative duty of the state in enforcing those rights but also the re-

47. ECtHR. Pavel Ivanov v. Russia. 20 February 2007. Application No. 35222/04 (decision).

48. ECtHR. Norwood v. the United Kingdom. 16 November 2004. Application No. 23131/03 (decision).

49. ECtHR (Grand Chamber). Stoll v. Switzerland. 10 December 2007. Application No. 69698/01. Para. 103. For a clear overview of the special rights and duties of journalists, as well as public servants, judges and lawyers under Article 10, I refer the reader to: Gerards, J.H. (2013). Artikel 10 EVRM - vrijheid van meningsuiting. In J.H. Gerards et al. (red.), Sdu Commentaar EVRM. Deel 1 - materiële bepalingen (pp. 856-1024). Den Haag: Sdu. 
sponsibilities of the individual to ensure that those rights are not abridged by his own actions. ${ }^{50}$

With regard to negative individual duties we may therefore conclude that the critics of the human duties declarations are correct in maintaining that human rights law already recognizes individual duties of non-interference and individual duties to exercise one's rights in a responsible fashion ${ }^{51} .^{52}$ Yet, the presence of such negative duties in human duties declarations (such as Article 12 DHSR $^{53}$ or Article $5 \mathrm{UDHRe}^{54}$ ) was not their main concern. Rather, the various positive duties to the community lie at the source of the disquiet felt by critics. The following subsection will therefore provide a brief overview of such duties present in these latter documents. It will be argued that both the status of the documents in question (i.e. a declaration as opposed to a binding treaty) and the place assigned to positive duties to the community within the document seem to indicate that the positive individual duties present in human rights law are not meant to be legally binding. However, what exactly the status of these duties is, why they have such a (moral or legal) status and what they exactly require of individuals is by no means made clear.

Furthermore, a second set of positive duties will appear equally (or perhaps even more) obscure. Positive individual duties of aid stemming from global subsistence needs are barely mentioned in human rights documents and, though they are perfunctorily mentioned by the drafters of the various human duties declarations, the drafters fail to even begin clarifying their content and status.

\section{§ 1.3.2 - Positive Individual Human Duties in International Human Rights Law}

The preceding subsection dealt with individual legal duties of a negative nature, the goal of which essentially consists in ensuring that the individual neither ac-

50. Beddard, R. (1999). The International Journal of Human Rights Duties of individuals under international and regional human rights instruments. The International Journal of Human Rights, 3(4), 30-48. 33.

51. By which I mean, as has been made clear, a duty to exercise one's rights with due regard for, inter alia, the rights of others, morality, the interests of national security, and the protection of public health.

52. Pace Van Leuven, who argues that international human rights documents merely do not explicitly exclude the horizontal application of human rights: Van Leuven. Contracten en mensenrechten. 75.

53. UNCHR. Human Rights and Human Responsibilities: "duty to exercise his or her recognized rights and freedoms, with due consideration and respect for the rights and freedoms of others."

54. InterAction Council. A Universal Declaration of Human Responsibilities: "Every person has a responsibility to respect life. No one has the right to injure, to torture or to kill another human person." 
tively breach the rights of others, nor exceed the limits of the legitimate exercise of his or her own rights. There are, however, also other, positive duties that await clarification. These duties include positive duties to the community as well as positive duties of aid arising from global subsistence needs.

The foremost example of the first kind of positive duties - i.e. duties to the community - is of course Article 29(1) of the UDHR, which states:

Everyone has duties to the community in which alone the free and full development of his personality is possible.

Despite its position at the end of the Declaration, it was certainly not deemed unimportant, or a last minute add-on. On the contrary, the drafting history ${ }^{55}$ of Article 29 shows that substantial time and effort were put into its formulation from the very beginning. It was certainly not an article added in haste at the last moment, but was rather intended as an important guide to adequately understanding the Declaration as a whole. The drafters wished to emphasize that sheer liberty is not the only goal of the Declaration. Instead, they argued that true freedom "could only be attained through perfect harmony between the individual and the community." 56

The drafting history furthermore shows that the relation between rights and duties in general was of fundamental importance for the drafters. There was a clear awareness that human rights alone, detached from individual duty, cannot endure:

In all human activity, both social and political, rights and duties are indissolubly linked with one another. While rights enhance individual freedom, duties express the dignity of that freedom. Duties of a legal nature presuppose others of a moral nature which facilitate their understanding and serve as their foundation ... Morality being

55. For a complete discussion of the drafting history of Article 29 UDHR, see: Daes, E.-I. (1990). Freedom of the Individual under Law: an Analysis of Article 29 of the Universal Declaration of Human Rights. Geneva: Centre for Human Rights. A somewhat shorter treatment of the drafting history can be found in: International Council on Human Rights Policy. (1999). Taking Duties Seriously: Individual Duties in International Human Rights Law. A Commentary. Versoix (Switzerland). 19-26. General guides to the Universal Declaration, which also discuss the role of Article 29, include Morsink, J. (1999). The Universal Declaration of Human Rights: Origins, Drafting and Intent. Philadelphia: University of Pennsylvania Press; and Glendon, M.A. (2001). A World Made New: Eleanor Roosevelt and the Universal Declaration of Human Rights. New York: Random House.

56. UN Doc. E/CN.4/SR.8 (31 January 1947). 4. Also see: UN Doc. E/CN.4/SR.14 (5 February 1947). 3; and UN Doc. E/CN.4/AC.1/SR.5 (8 December 1947). 7: The Declaration "should not seek to separate man from his community." 
the noblest product of culture, it is the duty of all to respect it at all times. ${ }^{57}$

Next to the striking resemblance with the preamble of the world's first international human rights document - the American Declaration of the Rights and Duties of $\mathrm{Man}^{58}$ - this passage is interesting for another reason. It clearly connects law with morality, and more specifically legal duties with moral duties. The question thus arises of what type the individual duties to the community were meant to be in the final version of Article 29(1). Erica-Irene Daes, in her elaborate study of Article 29, argues that Article 29(1) is a provision of a moral nature, "in the sense that it lays down a general rule for individual behavior in the community to which the individual belongs." ${ }^{59}$ This generality, this lack of specificity, is precisely the problem with such duties to the community as they are discussed in various human rights documents (as well as in the human duties declarations), as we will see.

The same lack of specificity can be found in Article 1 of the UDHR. It states that because all human beings "are endowed with reason and conscience" they "should act towards one another in a spirit of brotherhood." What actions are required, however, to fulfill this duty to treat others in a spirit of brotherhood remains unclear.

A passage very similar to Article 29(1) can be found in the fifth preambular paragraph of the two International Covenants:

[T] he individual, having duties to other individuals and to the community to which he belongs, is under a responsibility to strive for the promotion and observance of the rights recognized in the present Covenant.

Though inspired by Article 29(1) UDHR, the International Covenants go beyond the Declaration by mentioning not only duties to the community, but also to other individuals. These are furthermore specified as containing both negative duties of observance of rights and positive duties of promoting human rights. This passage presents us another clue concerning the question of the 
status of individual duties to the community. The ICCPR is, in fact, legally binding, yet its preamble is not. Placing the individual duties to the community in the preamble instead of in an article implies that the drafters did not intend for such duties to be of a legal nature. So far, it thus seems that the individual duties to the community mentioned in the International Bill of Human Rights are in fact intended as moral duties.

The ADRDM, however, appears to contain both moral and legal duties to the community. Starting with the preamble, it clearly emphasizes the interdependence of rights and duties:

The fulfillment of duty by each individual is a prerequisite to the rights of all. Rights and duties are interrelated in every social and political activity of man. While rights exalt individual liberty, duties express the dignity of that liberty. ${ }^{60}$

The ADRDM recognizes quite a few duties (its entire second chapter is dedicated to the duties of the individual). Here again we find several of Knox's "converse duties," which at first glance would appear to be moral rather than legal duties, such as duties to society, and the duty to honor one's parents. ${ }^{61}$ The ADRDM, however, also contains a number of duties to the community - such as the duty to vote, the duty to obey the law, the duty to work and to pay taxes ${ }^{62}$ - that are habitually viewed as legal duties (with the possible exception of the duty to vote). The content of these duties is clearly stated, rendering it possible to determine when an individual has and when he or she has not fulfilled his or her duty. As these are also duties that individuals have towards the state and towards society at large, they present us with our first example of individual duties to the community of a legal nature. ${ }^{63}$

60. Note how dignity is here connected to the fulfillment of duty. Throughout most of the history of moral philosophy this thought has had precedence over the idea that human dignity is primarily connected with rights. This is clearly shown by Oliver Sensen in Sensen, O. (2011). Human Dignity in Historical Perspective: The Contemporary and Traditional Paradigms. European Journal of Political Theory, 10(1), 71-91. his article "Human dignity in historical perspective: The contemporary and traditional paradigms." European Journal of Political Theory 10.1 (2011): 71-91.

61. ADRDM. Articles XXIX and XXX respectively.

62. Ibid. Articles XXXII, XXXIII, XXXV and XXXVI respectively.

63. Though, of course, the ADRDM is, as a declaration, strictly speaking not a legally binding document, although some argue that the ADRDM is now also a source of legal obligations for members of the Charter of the Organization of American States (hereinafter OAS): Pasqualucci, J. (2010). The Americas. In D. Moeckli, S. Shah, \& S. Sivakumaran (Eds.), International Human Rights Law (pp. 433-453). Oxford: Oxford University Press. 435. 
The American Convention on Human Rights, ${ }^{64}$ by contrast, barely speaks of individual human duties. Chapter V, entitled "Personal Responsibilities," only contains one Article:

\section{Article 32. Relationship between Duties and Rights}

1. Every person has responsibilities to his family, his community, and mankind

2. The rights of each person are limited by the rights of others, by the security of all, and by the just demands of the general welfare, in a democratic society.

Unlike the second chapter of the ADRDM, the ACHR thus does not provide any specific individual duties, but limits itself in Article 32(1) to broad, general duties to one's family, community and to mankind. Article 32(2) is a standard clawback clause, the function of which is to call on all bearers of rights to exercise those rights responsibly, i.e. with due regard for the rights of others and for the common good. Finally, the Convention contains a general abuse clause, not unlike Article 17 ECHR and Article 5(1) ICCPR, stating that none of its provisions "shall be interpreted as permitting any State Party, group, or person to suppress the enjoyment or exercise of the rights and freedoms recognized in this Convention." ${ }^{\circ 5}$

Like the ADRDM, the African Charter also prescribes private duties to the community. It does so with the express goal of incorporating within the African Charter distinctly African values. Thus it recognizes in Article 27(1) that "[e] very individual shall have duties towards his family and society, the State and other legally recognized communities and the international community." Article 29 , subsequently, provides us with an elaborate list of the various types of duties to the community alluded to in Article 27(1), which are considered to be, by the Charter itself, specifically African duties:

1. [T]o preserve the harmonious development of the family and to work for the cohesion and respect of the family; to respect his parents at all times;

64. The American Convention on Human Rights (hereinafter ACHR) was adopted by the OAS on 22 November 1969 and has been in force since 18 July 1978.

65. ACHR. Article 29(a). 
2. To serve his national community by placing his physical and intellectual abilities at its service;

3. Not to compromise the security of the State whose national or resident he is;

4. To preserve and strengthen social and national solidarity . . . ;

5. To preserve and strengthen the national independence and the territorial integrity of his country and to contribute to its defense in accordance with the law;

6. To work to the best of his abilities and competence, and to pay taxes imposed by law in the interest of the society;

7. To preserve and strengthen positive African cultural values ... and, in general, to contribute to the promotion of the moral well being of society;

8. To contribute to the best of his abilities . . . to the promotion and achievement of African unity.

As becomes clear from this list of duties, the ACHPR rejects the notion that duties should always be correlative to rights by presenting duties that run from the individual to the state, to the national community as well as to other groups, and to individuals, without corresponding rights. It is precisely for this reason that the ACHPR has been heavily criticized by human rights scholars. Some have expressed the fear that the many vertical human duties could be abused by authoritarian states. By referring to the duties of the Charter, states could restrict human rights whenever they conflict with duties to society or state. ${ }^{66}$ Essentially, this is the same critique that has been leveled at the human duties expounded by the drafters of the UDHRe and the DHSR.

These fears might prove to be somewhat unfounded, however, as the African Commission has taken no steps to clarify the content of these duties, ${ }^{67}$ save for the application of the general limitation clause of the ACHPR. ${ }^{68}$ It has held, furthermore, that all limitations of the rights expounded in the ACHPR should

66. Cohen, R. (1993). Endless Teardrops: Prolegomena to the Study of Human Rights in Africa. In R. Cohen (Ed.), Human Rights and Governance in Africa (pp. 3-38). Gainesville (FL): Florida University Press. 15; Knox. Horizontal Human Rights Law. 16: "[A] government could cite these duties as excuses to limit or override human rights."

67. Heyns, C., \& Killander, M. (2010). Africa. In D. Moeckli, S. Shah, \& S. Sivakumaran (Eds.), International Human Rights Law (pp. 479-497). Oxford: Oxford University Press. 485; cf. Steiner, H. J., \& Alston, P. (1996). International Human Rights in Context: Law, Politics, Morals. Oxford: Oxford University Press. 694.

68. African Charter. Article 27(2): "The rights and freedoms of each individual shall be exercised with due regard to the rights of others, collective security, morality and common interest." 
be in compliance with international human rights law standards. In this manner, it would seem that the African Commission has effectively rendered the positive duties to the community listed in the African Charter inoperative. One reason for this is that some of the duties mentioned in the Charter are already justiciable under the domestic law of the states parties, such as Article 29(2) (the duty of national service and defense), Article 29(3) ("Not to compromise the security of the State"), and Article 29(6) ("to pay taxes imposed by law in the interest of the society"). Another reason may be, with regard to the remaining duties, that the African Commission considers the duties not to be duties of a legal nature that may be enforced. These duties - such as Article 29(1) ("to preserve the harmonious development of the family"), Article 29(4) ("To preserve and strengthen social and national solidarity"), and Article 29(7) ("To preserve and strengthen positive African cultural values ... . and, in general, to contribute to the promotion of the moral well being of society") - thus assume the form of moral appeals, rather than of legal prescriptions. This conclusion is confirmed by the lack of specificity of these individual duties. ${ }^{69}$ It thus also remains unclear when one has adequately discharged one's duties. Ambiguous terms, such as "family," "African cultural values," "African unity," and "social and national solidarity" further obscure the meaning of the prescribed duties. This, in turn, renders practical enforcement of these duties problematic and leads us to conclude that, rather than strict legal obligations, these duties seem to be of a moral nature that may be fulfilled according to one's own insight and means.

We may conclude that duties to the community in human rights documents are generally interpreted as duties of a moral nature. Why this is the case, however, is not explained. Why certain duties may be enforced through legal means whereas others form but a moral appeal is never argued for. The basis for this distinction will therefore need to be exhaustively argued. This task will be undertaken in Chapter 2.

Furthermore, the content of the civic duties (as I will also call the duties to the community) listed in human rights documents is greatly underdetermined. What does it mean that we all have duties to the community, as Article 29(1) UDHR points out? What does serving one's national community (Article 29(2) ACHPR) exactly amount to? What does it mean that a document like the American Declaration lumps together duties to the community of a legal (e.g. duties to obey the law and to pay taxes) and of a moral nature (e.g. the duty to honor 
one's parents)? What community, exactly, is intended? Critics of human duties declarations may be correct when they state that there are already plenty of duties present in human rights documents, but given that they do not provide any clarity regarding the nature (Are they legal or moral duties, and why?), content and scope (What do I owe to whom, and why?) of duties to the community, it is by no means true that a renewed focus on individual duties within a human rights discourse is superfluous. For this reason, Chapter 5 will set out to determine the correct understanding of the content of these duties to the community as well as their status (legal or moral, that is, duties of justice or duties of virtue).

Matters are even worse when it comes to that other set of positive duties, to be discussed in Chapter 4, namely duties of aid. Concerning the duties of individuals regarding global poverty, we have very little to go on. Article 25 of the Universal Declaration and Article 11 ICESCR speak of a right to an adequate standard of living. Nowhere in these documents, however, do we find a clue concerning individual duties correlative to this right. In the General Comments issued by the Committee on Economic, Social and Cultural Rights (CESCR), which are meant to function as interpretations of the provisions of the ICESCR, we merely find very vague allusions to individual duties. For example, all members of society (including individuals) are said to "have responsibilities in the realization of the right to adequate food." 70 What these responsibilities are and how responsibilities differ from "obligations," a word apparently reserved for the duties of the state, remains unclear. If I wish to know which duties are placed on my shoulders as a consequence of Article 25 UDHR, I will not find any answers in human rights documents or in the General Comments of the CESCR (as will be more elaborately argued in \$3.1).

The human duties declarations do not fare much better. Article 9 of the UDHRe holds that all "[a]ll people, given the necessary tools, have a responsibility to make serious efforts to overcome poverty, malnutrition, ignorance, and inequality." Yet, what constitutes "serious efforts," and whether we owe this duty to all human beings or only to our compatriots is never clarified. Similarly, Arti-

70. CESCR. General Comment 12: The Right to Adequate Food (Art. 11). E/C.12/1999/5 (12 May 1999). Para. 20. The ICESCR and the General Comments of the CESCR are generally extremely state-focused. Duties of non-state actors - such as corporations, international financial institutions, and NGOs - are not dealt with extensively either. A typical description of their duties can be found in the CESCR's Statement on Poverty: "Non-State actors, including international organizations, national human rights institutions, civil society organizations and private businesses, also have heavy responsibilities in the struggle against poverty." CESCR. Statement on Poverty and the ICESCR, E/C.12/2001/10 (10 May 2001). Para. 20. Again, what these responsibilities are, is left open. 
cle 20 DHSR states that one has a duty to use one's wealth "for the benefit of the progress of Humanity as a whole." Yet, how does one contribute to the "progress of Humanity?" What exactly is even meant by the "progress of Humanity?" Are these duties intended as moral duties or as enforceable legal duties? What happens if one does not perform these duties? All these questions still remain unanswered. Both the content and the status (moral or legal) of individual duties of aid with regard to global subsistence needs remain unclear. Human rights documents and human duties declarations both have contributed next to nothing to their elucidation.

Not wishing to accept the implication that individuals therefore have no duties with regard to global subsistence needs, Chapter 4 will set out to provide an account of our duties of aid, as well as the status of these duties (legal or moral) and their scope. For now, we can only conclude that regarding individual positive duties - both duties of aid and duties to the community - human rights discourse does not take individual duties seriously enough to care to clarify them. ${ }^{71}$ Furthermore, the drafters of the human duties declarations may aspire to put individual duties back on the map, but it seems they are not the best cartographers. Reconsidering our duties is therefore by no means a superfluous pursuit, as our positive duties in particular remain largely shrouded in mystery.

\section{$\S 1.4$ - Conclusion: Human Duties Compared}

Neither the critics nor the proponents of the various declarations emphasizing human duties would disagree with the statement that individual human duties are indispensable for the full realization of human rights. Opinions diverge only where the type and scope of such duties are concerned. Despite the fact that some would argue that "the language of individual duty in the universal human rights system is rare,"72 the preceding sections have pointed out that there has in fact been more attention for individual duties in international human rights documents than initially expected. Nonetheless, it remains true that "the desirable role of 'duties' in modern human rights theories is unclear," 73

71. Despite the hope-giving title of a publication by the International Council on Human Rights Policy mentioned earlier: Taking Duties Seriously: Individual Duties in International Human Rights Law. A Commentary. This publication, however, also contains no specific answers concerning the positive individual duties that interest us here.

72. Steiner and Alston. International Human Rights in Context. 181.

73. Devereux, A. (1995). Should “Duties” Play a Larger Role in Human Rights? A critique of Western Liberal and African Human Rights Jurisprudence. UNSW Law Journal, 18(2), 464-482. 464. 
particularly where the positive duties to the community and duties of aid are concerned. For this reason, the advent of human duties declarations in the past two decades should be considered, even by its opponents, as a blessing (albeit in disguise, from the critics' perspective). It forces human rights scholars and legal philosophers alike to confront the question of individual human duties: their content, scope and status as well as their relation with rights all require further clarification, for as we have concluded at the end of the previous section, the positive individual duties mentioned in human rights documents remain far too underdetermined.

This chapter has set a first step in such elucidation by discussing both the duties listed in the various human duties declarations (chiefly the UDHRe and the DHSR) and those listed in international human rights documents. The most often recurring question in this comparison was which duties may be enforced by law and should therefore be considered legal duties, and which, conversely, may not be enforced by law (because the degree and manner of fulfillment of such duties is the prerogative of the individual) and are therefore to be regarded as moral duties. The present chapter has taken some first steps in distinguishing the former from the latter, both in declarations emphasizing human duties and in human rights documents. However, much work remains to be done here. Indeed, as became clear in $\$ 1.2$, one of the main problems with human duties declarations as the UDHRe and DHSR lies in the confusion of moral and legal duties. On the one hand, they contain, for example, the duty to respect life (Article 5 UDHRe) - a clear legal duty, recognized by international human rights law - and on the other hand they propose duties to "promote good and to avoid evil in all things" (Article 3 UDHRe) or to develop one's talents "through diligent endeavor" (Article 10 UDHRe), which appear to be moral duties.

This confusion of law and morality, however, is not unique to the drafters of human duties declarations. The criticism of most opponents of such declarations generally consists in simply asserting that these declarations confuse legal with moral duties, without ever clarifying wherein such a distinction would consist. The difference between law and morality is never argued for, but rather posited as a fact. As said, the advent of human duties declarations is a positive development, for it forces us to (re)think some of the fundamental distinctions that lie at the basis of all (human rights) law. How does law (or justice) differ from morality (or virtue)? On the basis of what criteria are we able to distinguish between duties of justice and duties of virtue? These questions have not at all been addressed by the critics of human duties declarations, nor by their proponents. 
Yet, without clear ideas about how to answer these questions, the discussion between these two camps amounts to mere assertions of the one camp concerning the incorrectness of the other's position. ${ }^{74}$

In $§ 1.3$ it was demonstrated that, despite the leveling of harsh criticisms against the declarations of human duties, the concept of individual human duties is not at all foreign to human rights documents. Even in human rights treaties such as the ECHR and the ICCPR - documents not exactly known for their emphasis on human duties, unlike the ACHPR and the ADRDM, for instance - we were able to find quite a number of individual human duties of a legal nature. Several articles of the ECHR and the ICCPR - such as those safeguarding the right to freedom of expression, the right to freedom of thought, conscience and religion, the right to freedom of assembly and association, and the right to liberty of movement - contain so-called "clawback clauses" that place limits on the mentioned rights, thus implying an individual human duty to exercise these rights responsibly. Though some would consider such clawback clauses dangerous, as they appear to limit the scope of human rights, other human rights scholars have argued that they are necessary in order to ensure the compatibility of everyone's rights. They, in fact, "enhance the level of consideration owed to other individuals and the community." 75

This reasoning, that one has a duty to exercise one's rights in a responsible manner has also found its way into international human rights law. Accordingly, the ECtHR argued in Pretty v. United Kingdom that the limitation of the applicant's right to private life - here interpreted as the right to personal autonomy, which the Court defined as "the ability to conduct life in a manner of one's own choosing" " was "justified as 'necessary in a democratic society' for the protection of the rights of others." 77 The Court thus recognized that human rights do not

74. Even the distinction between correlative and converse duties offered by Knox is simply posited (without argument) as self-evident, whereby horizontal, correlative duties are assumed to be legal duties and vertical, converse duties are assumed to be of a moral nature. However, the vertical duties to the community or the state to pay taxes, vote, obey the law, and render civic or military service clearly show that the correlative-converse distinction does not neatly correspond to the division between law and morality, respectively. Furthermore, beneficence surely is a horizontal duty, yet it is generally considered to be a moral duty, thus again showing that Knox's distinction is inadequate. Finally, Knox's distinction between correlative and converse duties ignores the duties to oneself, as prescribed by the human duties declarations. The distinction between law and morality (and their respective duties) therefore needs to be carefully argued for, not assumed. Providing precise arguments for the division of these two realms will be the goal of the next chapter.

75. Hodgson, D. (2003). Individual Duty within a Human Rights Discourse. Aldershot: Ashgate. 98.

76. ECtHR. Pretty v. United Kingdom. 29 April 2002. Application No. 2346/02. Para. 62.

77. Ibid. Para. 78. 
ensure a personal autonomy without bounds. Instead, with this judgment it made clear that "personal autonomy finds its boundaries in the rights of others." "78

In $\$ 1.3$ many more such examples have been given that attest to the presence of individual duties to respect the rights of others (as well as public health, order and morals) by exercising one's own rights in a responsible fashion. Up until this point, existing human rights law and the proponents of the various human duties declarations are still in agreement. Yet, despite the presence of such duties in human rights law, the drafters of the UDHRe and the DHSR retain that human rights and human duties, freedom and responsibility, are still not in balance. They insist that the emphasis lies too heavily on human rights and individual freedom, and not enough on human duties and the good of the community. In order to remedy this imbalance, they propose individual duties owed to society at large, as well as duties to oneself. Generally, such duties are quite admirable. Indeed, no one would deny the commendable nature of the duty "to behave in a fraternal manner toward others" (Article 14 DHSR), the duty "to contribute [...] to the eradication of social ills that affect or destroy key elements in the effective dignity and freedom of others" (Article 21 DHSR), or the duty "to develop, to the greatest degree possible, his or her intellectual, spiritual, physical and emotional capacities, both for his or her own benefit and for that of the community" (Article 25 DHSR). However, critics of human duties declarations would argue that, honorable as such duties may be, they find their proper place in morality, not in legally binding documents. Though proponents of human duties declarations do indeed explicitly define (without providing arguments, however) the proposed human duties as moral, rather than legal, it remains odd that at the same time the InterAction Council wishes the UDHRe to attain the same status as the UDHR. Critics fear this could lead such human duties declarations to obtain, like the UDHR, the status of customary international law, or to inspire a legally binding document, much like the UDHR inspired the International Covenants. It is precisely this ambiguity with regard to the desired legal status of such declarations that unnerves many human rights advocates, who insist that such duties cannot and should not be legally binding. They argue that granting legal status to these declarations would result in practical problems of enforcement and, more importantly, they fear that the promotion of human duties will lead to the unduly limitation of human rights. Finally, they worry 
that governments might now feel justified in imposing certain duties of a moral nature, resulting in paternalism.

In order to clearly ascertain why (and if) some of the duties discussed in this chapter are indeed moral duties and therefore should have no place in any (even potentially) legally binding document, we will need to gain a fuller understanding of the distinction between moral and legal duties, which is what the following chapter sets out to provide. The clarification of the distinction between these two sets of duties will rely on the prior elucidation of the underlying distinction between morality (virtue) and law (justice), which will be provided in Chapter 2 as well.

Finally, we found (in §1.3.2) that both individual positive duties of aid and duties to the community are severely underdetermined in human rights documents and human duties declarations. Contrary to the claim of critics that a renewed focus on individual duties is superfluous, we will need to elaborately study these two positive duties, as we have found that the human rights perspective does not help us understand the nature, content and scope of the demands they place on us. Accordingly, Chapter 4 will examine individual duties of aid arising from global subsistence needs, Chapter 5 will consider the complicated case of individual duties to the community, and Chapter 3 will examine them both from a juridical perspective. 



\section{CHAPTER 2 - DUTIES AND RIGHTS}

[W[hoever does not place the distinction between justice and morality in general where we have now placed it, will be found to make no distinction between them at all, but to merge all morality in justice. ${ }^{1}$

In the previous chapter we examined various human duties from both human rights documents and human duties declarations. Without having provided the necessary conceptual framework, which will be undertaken in this chapter, we provisionally noted that certain duties (such as the duty to develop one's talents or to help eradicate the social ills of one's society) do not belong within the sphere of legally binding documents, whereas others (such as the duty to refrain from assaulting others) clearly do. The reason why certain duties can be legal duties (with corresponding rights) whereas others cannot, however, still needs to be clarified. Such clarification will require an exposition of the central concepts involved, that is, duties and rights. Regarding the former, we will, furthermore, need to explain the two central distinctions that can be made regarding our duties: the distinction between perfect and imperfect duties and the distinction between duties of justice and duties of virtue. Explicating the latter distinction will, moreover, involve elucidating the terms "justice" and "virtue" themselves as well as their mutual relation. These terms and distinctions will be clarified here, at the outset of the dissertation, as they will frequently prove useful in the remainder of this study. In short, this chapter will provide a theory of duties and rights, which will in the subsequent chapters allow us to resolve several practical problems from the fields of human rights law and politics.

In keeping with the general theme of this dissertation (the importance of a renewed focus on duties), we will start this chapter not by an exposition of rights (which will be undertaken in \$2.2), but rather with an exploration of duties (in \$2.1). This is not merely a matter of exposition. The larger point I wish to make in this chapter is that looking at morality ${ }^{2}$ from the perspective of rights severely diminishes the scope of our moral landscape. By starting from rights we are able

1. Mill, J. S. (2008). Utilitarianism. In J. Gray (Ed.), On Liberty and Other Essays (pp. 129-201). New York: Oxford University Press. 186.

2. The term "morality" will from now on no longer be used in opposition to the term "law," but rather as the more general term comprising the realms of both justice and virtue. 
to recognize solely one type of duty, namely duties of justice (as only these have corresponding rights), resulting in the reduction of all actions going beyond such duties to merely optional acts of supererogation. Starting from duties will allow us to steer clear of this error and thus redeem imperfect duties and duties of virtue from inconsequentiality. Far from endangering our rights, this approach will, additionally, render our rights more clear and robust.

Before moving on to the discussion of duties and rights, perhaps a word on the theoretical background of the present chapter is in order. As announced in the introduction, I will be relying heavily on the work of Immanuel Kant in order to clarify the various kinds of duties as well as our rights. The choice for Kant was not made at random. Kant's political and legal philosophy are constant sources of inspiration for contemporary thoughts on justice, human rights, international intervention, and similar matters. ${ }^{3}$ Furthermore, a dominant strand of contemporary political theory (comprising the works of, e.g., Alan Gewirth, Onora O'Neill, Thomas Pogge, and John Rawls,) is Kantian in nature. The ideas developed by Kant concerning matters of justice and virtue have had and continue to have a profound influence on contemporary debates in the fields of political and legal philosophy. To understand and present these ideas properly will, therefore, not only help us to better understand the problems at hand, but will also allow us to participate in an ongoing debate in which Kantian philosophy occupies a place of prominence.

\section{§ 2.1 - On Duties}

Generally, we could define "duty" as an action to which one is bound. It is a specific action one is obligated (that is, literally bound) to perform. Within this very generic understanding of duty, however, several distinctions can be made. Most importantly, we can distinguish between perfect and imperfect duties as well as between duties of justice and duties of virtue. As will become clear, these two sets of duties are intimately connected, yet not strictly synonymous.

3. See, for example, Kleingeld, P. (2012). Kant and Cosmopolitanism: the Philosophical Idea of World Citizenship. Cambridge: Cambridge University Press; Williams, H. (2012). Kant and the End of War: a Critique of Just War Theory. London: Palgrave Macmillan; Roff, H. M. (2013). Global Justice, Kant and the Responsibility to Protect: A Provisional Duty. New York: Routledge; Follesdal, A., \& Maliks, R. (Eds.). (2014). Kantian Theory and Human Rights. New York: Routledge; Flikschuh, K., \& Ypi, L. (Eds.). (2014). Kant and Colonialism: Historical and Critical Perspectives. Oxford: Oxford University Press; Lesser, A. H. (Ed.). (2015). Kant's 'Doctrine of Right' in the Twenty-first Century. Cardiff: University of Wales Press. Forthcoming. 
This section will start by expounding (in §2.1.1) the difference between perfect and imperfect duties. Next to clarifying this distinction, I aim to refute the common assumption that imperfect duties (often associated with duties without corresponding rights) are less binding and less important than perfect duties (often understood as duties with corresponding rights), an assumption intimately connected with the perspective of rights, which, I intend to demonstrate in $\$ 2.2$, is undesirable. Subsequently, $\$ 2.1 .2$ will elucidate the distinction between duties of justice and duties of virtue. In the process, it will also prove necessary to clarify and assess Kant's understanding of the terms "justice" and "virtue." Whereas justice is concerned solely with the regulation of our actions in order to set up and maintain a system of equal spheres of freedom for all, virtue is instead concerned with regulating the principles on which we act as well as the inner disposition underlying our outward acts. Finally, after having thus emphasized the differences between justice and virtue, $\$ 2.1 .3$ will examine the relation between these two spheres of morality. I will distance myself from Kant's strict separation of these two spheres and argue instead for their interdependence.

\section{$\S$ 2.1.1 - Perfect and Imperfect Duties}

Etymologically, perfect duties are complete duties and imperfect duties are incomplete duties. ${ }^{4}$ But in what sense are these duties (in)complete? In contemporary discussions, duties are typically considered incomplete (and thus imperfect) when neither the duty-bearer nor the precise content of the duty nor the recipient of the duty has been determined. By contrast, in the case of perfect duties "who the agent is, what her exact responsibility is, and to whom she owes this responsibility are clearly defined." ${ }^{5}$ From this incompleteness, it follows that imperfect duties are not claimable (and therefore, a fortiori, not enforceable), nor do they give rise to corresponding rights. Non-performance of imperfect duties, finally, does not give rise to demerit, whereas violation of perfect duties does.

These differences between the two sets of duties have led many contemporary scholars to believe that perfect duties are more binding and of greater 
moral importance than imperfect duties. ${ }^{6}$ It is this belief that I mean to refute in this subsection. I will do so by expounding the distinction between these two duties as understood by Kant, on whose work so many scholars (either explicitly or implicitly) erroneously base their claim that imperfect duties carry less moral weight and allow for a greater permissiveness than perfect duties. I will argue that imperfect duties do indeed allow for discretion on the side of the agent, they do lack corresponding rights, and their non-performance is indeed permitted. Yet, all this does not warrant the conclusion that they are less important or merely optional excellences. Before undertaking this task, however, I will start by providing a brief historical sketch of the development of the perfect-imperfect distinction.

The rough outlines of the distinction between perfect and imperfect duties as it is commonly drawn today can be traced back to the work of the $17^{\text {th }}$ century Dutch jurist and legal philosopher Hugo Grotius, ${ }^{7}$ as does the habit of connecting perfect rights (or "faculties") and duties to justice and imperfect rights (or "aptitudes") and duties to virtue. Thus, according to Grotius, rights that may be enforced, and the violation of which constitutes a wrong, are perfect in nature, whereas imperfect rights may not be enforced, nor is anyone wronged by their violation. ${ }^{8}$ Having some moral reason to see a duty performed is therefore not enough to render the duty perfect. Only if we have a perfect right to its performance does its non-fulfillment constitute a violation of justice. Otherwise, the duty in question is imperfect and its fulfillment is a matter not of justice, but virtue ("Liberality, Gratitude, Compassion, or Charity"). ${ }^{9}$

The German philosopher and jurist Samuel von Pufendorf adopts Grotius's distinction and develops it further. He views perfect rights as those warranting the use of force (i.e. legal action in a civil state or, between states, war) against

6. See, e.g., Ashford, E. (2006). The Inadequacy of our Traditional Conception of the Duties Imposed by Human Rights. Canadian Journal of Law and Jurisprudence, XIX(2), 217-235. 219-20; Gilabert, P. (2010). Kant and the Claims of the Poor. Philosophy and Phenomenological Research, 81(2), 382-418. 394ff; Waldron, J. (1993). Liberal Rights: Collected Papers 1981-1991. Cambridge: Cambridge University Press. 14. The first two authors strive to define duties to help the (global) poor as perfect duties of justice, as they believe imperfect duties to be less weighty duties.

7. Schneewind, J.B. (1998). The Invention of Autonomy: A History of Modern Moral Philosophy. Cambridge: Cambridge University Press. 78. Though some would argue that a similar distinction - that between duties of justice and duties of material aid - can already be found in Cicero's De Officiis: Nussbaum, M. (2000). Duties of Justice, Duties of Material Aid: Cicero's Problematic Legacy. The Journal of Political Philosophy, 8(2), 176-206.

8. Grotius, H. (2005). The Rights of War and Peace. (J. Barbeyrac, Trans, R. Tuck, Ed.). Indianapolis: Liberty Fund. I.I.iv; cf. II.XII.ix.2.

9. Ibid. II.XXII.xvi. 
those who would violate them. ${ }^{10}$ By contrast, the performance of imperfect duties, such as "duties of humanity, beneficence, and gratitude," 11 cannot be extorted by force. The reason why, according to Pufendorf, perfect rights and duties are and ought to be enforceable, is that the performance of perfect duties and the protection of perfect rights are necessary if society is to exist at all. Imperfect rights and duties, on the other hand, contribute to society's wellbeing. There are, in other words, certain duties without the performance of which society could not be conceived to persist at all. These are perfect duties. Instead, we can conceive of a society persisting through time even though all members of this society neglect their imperfect duties. Very concretely, on this view, society cannot be imagined to continue to exist if no one would perform the perfect duty to refrain from killing innocent people, but it could be thought to persist if no one would ever perform their imperfect duty of aiding the poor. Thus, given the importance of perfect duties for the very existence of society, they ought to be enforceable; no such need, however, pertains to imperfect duties.

Pufendorf, furthermore, maintains that the content of perfect duties is clearly defined, whereas imperfect duties do not prescribe as precisely. In the case of the provision of goods, for example, imperfect duties do "not consider whether that which is furnished is equal or not to that on account of which something is owed."12 In the case of imperfect duties the agent can therefore not rely on clear legal prescriptions, but must instead follow her own "sense of decency and conscience." 13 How much one ought to give, is thus left up to the discretion of the agent.

In sum, we have seen thus far how according to Pufendorf perfect duties are characterized by enforceability and precision, whereas unenforceability and lack of precision are traits associated rather with imperfect duties. The former are, moreover, crucial to peaceful coexistence in society as such, whereas the latter contribute "only" to the flourishing of that society. ${ }^{14}$

Finally, one can distinguish between perfect and imperfect duties regarding the moral merit (or demerit) resulting from their (non-)performance. When the performance of an action is owed to another (as a matter of right) - be it a special duty, such as repaying a debt, or a universal duty, such as refraining from

10. Pufendorf, S. (1994). On the Law of Nature and of Nations in Eight Books. In C.L. Car (Ed.), M.J. Seidler (Trans.), The Political Writings of Samuel Pufendorf (pp. 93-268). Oxford: Oxford University Press. I.i.19.

11. Ibid. I,vii.15.

12. Ibid. I.vii.8.

13. Ibid. I. vii. 7.

14. Kersting, W. (2004). Kant über Recht. Paderborn: Mentis Verlag. 204. 
assaulting others - performing it will not result in merit, for "the bare Omission of forbidden Actions is utterly unable to produce any Merit, or any Matter for Boasting or for Praise." ${ }^{15}$ By performing these duties I am only giving others their due, i.e. that to which they have a right and which is therefore in a sense already theirs. When one instead performs an action, to which the beneficiary did not have a right, then one acquires merit. If we did not owe the performance of a particular action to others, then our action is meritorious. By contrast, when one fails to perform duties one owes to others - by, for example, injuring them the result is demerit and one is obliged to provide some form of compensation. Given that those duties, the performance of which is owed by right either to all (in the case of rights in rem) or to specific others (in the case of rights in personam) are called perfect duties, whereas those duties that cannot be claimed by right and thus are not owed are termed imperfect duties, we can sum up Pufendorf's position regarding merit and demerit as follows: the performance of imperfect duties gives rise to merit, the failure to perform perfect duties gives rise to demerit, and the performance of perfect duties gives rise neither to merit nor to demerit but appears to be morally neutral. We have seen, furthermore, that perfect duties have correlative rights, whereas imperfect duties do not.

The various elements used by Pufendorf to distinguish perfect from imperfect duties - (un)enforceability, importance for the very existence or for the "mere" flourishing of society, duties to refrain from injury as opposed to duties of aid and charity, (lack of) clarity of definition, (no) corresponding rights and whether performance of the duty in question gives rise to merit and its omission to demerit - frequently return in accounts of perfect and imperfect duties. Scholars may add or omit elements, they may emphasize some traits at the cost of others, and the philosophical foundation of their accounts of duties may vary, yet these remain the most central elements of the perfect-imperfect distinction.

Thus, for example, two centuries later John Stuart Mill would describe imperfect duties, such as duties of charity or beneficence, as duties all are bound to perform. How, when and toward whom we are to perform these duties, however, is not specified and is therefore left to our discretion. Imperfect duties, furthermore, do not give rise to correlative rights. ${ }^{16}$ No one can claim a right, therefore, to our beneficence. Perfect duties, by contrast, do prescribe in a precise fashion and involve correlative rights. Mill, furthermore, assigns perfect duties to the 
sphere of justice and imperfect duties to the sphere of beneficence, which implies that perfect duties are enforceable and imperfect duties are not. Finally, he grants primacy to the dictates of justice (which consist of perfect duties) over other dictates of morality, as the rules of justice "concern the essentials of human well-being more nearly, and are therefore of more absolute obligation, than any other rules for the guidance of life." ${ }^{\prime 17}$

In contemporary accounts of perfect and imperfect duties, authors often focus on the indeterminacy of imperfect duties: who must do what for whom is not specified, thus allowing the duty-bearer considerable latitude. ${ }^{18}$ As a consequence, it is often thought that one may choose to perform imperfect duties at one's pleasure: given that the imperfect duty itself does not prescribe when, how and for whom one must perform it, the duty-bearer is at liberty to choose herself when (and when not), in what manner and for whom she performs the imperfect duty in question. Furthermore, she need not act in accordance with her imperfect duties whenever the opportunity presents itself; so long as she sometimes performs her duties, she has not violated them. It is clear to see how such an understanding of the indeterminate nature of imperfect duties can lead to the common thought in contemporary discussions of imperfect duties that such duties are less important. ${ }^{19}$ The thought that imperfect duties do not provide as clear guidelines for our behavior as perfect duties do, has a long history, as shown above. But the conclusion that one may for this reason perform them as and when one wishes and that imperfect duties are thus shown to be less important is peculiar to the view prevailing among scholars today.

That imperfect duties prescribe less clearly than perfect duties is, more often than not, simply postulated in contemporary discourse. Why they prescribe in a less determinate fashion is rarely considered in recent discussions. Yet, once we know why the content of imperfect duties is not as clearly specified as the dictates of perfect duties, we will find that the latitude involved in imperfect duties does not warrant the claim that they are somehow less important or less binding than perfect duties. To illustrate this point - that imperfect duties are

17. Ibid. 195. Cf. 200 and 201.

18. See, e.g.,; Ashford. The Inadequacy of our Traditional Conception. 219; Gilabert. Kant and the Claims of the Poor. 391ff.; Griffin, J. (2008). On Human Rights. Oxford: Oxford University Press. 51, 96; Stemplowska, Z. (2009). On the Real World Duties Imposed on Us by Human Rights. Journal of Social Philosophy, 40(4), 466-487. 481-2. Tan. Justice Without Borders. 50.

19. Daniel Statman describes this common understanding of imperfect duties and criticizes it, arguing it leads to "yuppie ethics:" when a large portion of our duties comes to be viewed as wholly optional and not as important as our stricter duties, this results in the performance of the former duties only when it is convenient: Statman, D. (1996). Who Needs Imperfect Duties? American Philosophical Quarterly, 33(2), 211-224. 221-2. 
equally important and by no means optional - we turn now to a discussion of Kant's understanding of the perfect-imperfect distinction.

In The Metaphysics of Morals Kant states that the less precise nature of imperfect duties arises from the fact that imperfect duties do not prescribe specific actions, but rather maxims for actions:

if the law can prescribe only the maxims of actions, not actions themselves, this is a sign that it leaves a playroom (latitudo) for free choice in following (complying with) the law, that is, that the law cannot specify precisely in what way one is to act and how much one is to do by the action for an end that is also a duty. ${ }^{20}$

Given that Kant understands maxims as subjective principles of action, ${ }^{21}$ it is clear why duties prescribing only maxims for actions instead of specific actions must allow for some latitude. The duty of beneficence, for example, does not command us to donate a specific amount to a specific charity or to volunteer at least a certain number of times per month at the local homeless shelter. Rather, imperfect duties (such as the duty of beneficence) call for the adoption of maxims to promote certain ends (that is, I ought to make it my subjective principle for action to promote a certain end). In what way we ought to promote the end, however, and how much we ought to do in promoting it, is left for us to decide.

Note that the fact that imperfect duties allow a degree of latitude has nothing to do with their supposedly inferior moral weight. The latitude results, instead, from the fact that imperfect duties do not command us to act in specific ways, but rather to adopt certain principles. The imperfect duty of beneficence, for example, does not prescribe specific beneficent acts, but rather requires us to adopt the maxim of making other people's happiness our end. ${ }^{22}$ The manner in which, however, this maxim is to be applied in specific circumstances is a question, the resolving of which necessarily requires a "call upon judgment." 23

20. Kant. The Metaphysics of Morals. Ak 6:390; cf. Kant, I. (1968). Vorarbeiten zur Tugendlehre. In Kants Werke. Bd. 23: Vorarbeiten und Nachträge (pp. 371-420). Ausgabe der Königlich Preußischen Akademie der Wissenschaften. Berlin: Walter de Gruyter. 394.

21. Kant, I. (1996). Groundwork of The Metaphysics of Morals. In M. Gregor (Ed. \& Trans.), Practical Philosophy (pp. 41-108). Cambridge: Cambridge University Press. Ak 4:420n; cf. Ak 4:400n. Also see Kant. The Metaphysics of Morals. Ak 6:225.

22. Kant. The Metaphysics of Morals. Ak 6:452.

23. Ibid. Ak 6:411. Jens Timmermann discusses the need for judgment and casuistry in the case of duties of virtue in the context of possible conflicting grounds of obligation: Timmermann, J. (2013). Kantian Dilemmas? Moral Conflict in Kant's Ethical Theory. Archiv Für Geschichte Der Philosophie, 95(1), 
We may promote the happiness of those in need by aiding them materially (that is, by donating money), but how much we ought to give depends on our means, on the presence or absence of social security, on our knowledge of the precise needs of specific others, and on a myriad of other contingent factors. But we may also help them politically, by lobbying for expansion of the social safety net, for instance. Onora O'Neill is, therefore, correct when she maintains that “[i] mperfect duties require agents to adopt ends or policies [instead of prescribing or prohibiting specific actions], but underdetermine the choice of occasions and ways of pursuing them." ${ }^{24}$

The latitude of imperfect duties does also not imply that they are more permissive, or any less binding, than perfect duties, as Kant goes on to say immediately following the passage quoted above: "But a wide duty is not to be taken as permission to make exceptions to the maxims of actions but only as permission to limit one maxim of duty by another (e.g., love of one's neighbor in general by love of one's parents)." ${ }^{25}$ The latitude agents have in performing imperfect duties does thus not imply a permission to refuse to adopt the maxim enjoined by a particular imperfect duty. At most, it allows agents to limit one maxim of duty by another (e.g., an agent may refrain from donating money to charity, because she requires it to help pay for her father's medical care).

One may, therefore, in contrast to perfect duties, refrain from performing an imperfect duty without incurring demerit, but only because (in the example given) one is not capable of both donating to charity and helping one's elderly father. If, however, one refrains from performing an imperfect duty on principle - e.g., one has made it one's maxim not to help others whenever it should involve any personal cost or setback - one does incur moral culpability: ${ }^{26}$ "the latitude of imperfect duties does not license us just to forego - for no particular reason - an opportunity to help someone but only licenses foregoing such an opportunity because it is impossible both to help that person and to help another." ${ }^{27}$

The performance of imperfect duties is thus not optional. It is not beyond the call of duty. In contemporary accounts, imperfect duties are often nearly equated to acts of supererogation by viewing their performance as optional. Instead, on a Kantian account, imperfect duties are just as morally binding as

24. O’Neill, O. (2013). Acting on Principle: An Essay on Kantian Ethics. Cambridge: Cambridge University Press. 19.

25. Kant. The Metaphysics of Morals. Ak 6:390. The term "wide duty" is here used as a synonym for "imperfect duty."

26. Ibid.

27. Baron, M. (1995). Kantian Ethics Almost Without Apology. Ithaca: Cornell University Press. 89. 
perfect duties. It is for this reason that Kant states that observing a person performing her duty - perfect or imperfect - ought not to inspire awe in us, for that would cause "a lowering of our feeling for duty, as if to act in obedience to it were something extraordinary and meritorious." ${ }^{28}$ Performing one's imperfect duties is therefore not especially saintly or heroic, but "simply" a matter of duty. ${ }^{29}$ It is true that one may choose to fulfill one's duty of beneficence by donating to this charity or that, by volunteering at a refugee center or at the soup kitchen, but one may not choose to do nothing: "Morality tells you: do whatever you like [to discharge your duty of beneficence, e.g.] - but do it." ${ }^{30}$

Moreover, there may be situations in which imperfect duties command nearly as strictly as perfect duties, excluding any freedom to choose in what way we will discharge our duty. For example, if I am truly committed to the duty of beneficence, I cannot stand by idly while a child is drowning in a pool. Doing nothing in this case would demonstrate that I am not truly committed to this duty, as a consequence of which, Kant clearly states, I incur moral culpability. ${ }^{31}$ In this case, the performance of the specific means of discharging my imperfect duty of beneficence allows for no latitude. Not saving the child in order to go volunteer at the local soup kitchen instead (as an alternative way of fulfilling my duty of beneficence) is not a permissible choice and would be an indication that one's commitment to beneficence is not sincere. ${ }^{32}$ Certain situations thus do away with my freedom to choose how to fulfill my duty of beneficence, and lay a very specific duty on my shoulders. In this manner, an imperfect duty can approach the precision of perfect duties.

28. Kant, I. (1996). Religion within the Boundaries of Mere Reason. In A. Wood \& P. Guyer (Eds.), G. Di Giovanni (Trans.), Religion and Rational Theology (pp. 39-215). Cambridge: Cambridge University Press. Ak 6:49. Also see Kant's rejection of the in his day common extolling of "heroes of romance" with their "elevated" ideals of extravagant moral greatness: Kant, I. (1996). Critique of Practical Reason. In M. Gregor (Ed. \& Trans.), Practical Philosophy (pp. 137-271). Cambridge: Cambridge University Press. Ak 5:155.

29. Unfortunately, I cannot delve into the lively discussion concerning the question whether or not Kant's moral system can accommodate acts of supererogation. I have only, very briefly, provided an argument why supererogation has no place in Kant's moral system by way of demonstrating that imperfect duties are not any less binding than perfect duties. It is pleasant to see this also appears to be the consensus in Kant scholarship. See, e.g., Baron. Kantian Ethics; Hope, S. (2014). Kantian Imperfect Duties and Modern Debates over Human Rights. The Journal of Political Philosophy, 22(4), 396-415; Timmermann, J. (2005). Good but Not Required? - Assessing the Demands of Kantian Ethics. Journal of Moral Philosophy, 2(1), 9-27. For the contrary position - that is, that (some) Kantian imperfect duties can be viewed as supererogatory - see Hill, T. E. (1971). Kant on Imperfect Duty and Supererogation. Kant-Studien, 62(1-4), 55-76.

30. Timmermann. Good but Not Required? 21.

31. Kant. The Metaphysics of Morals. Ak 6:390.

32. This point is made very clearly by Alice Pinheiro Walla in her recent article: Pinheiro Walla, A. (2015). Kant's Moral Theory and Demandingness, Ethical Theory and Moral Practice. Advance online publication. doi:10.1007/s10677-015-9600-x. 
Still, other differences (besides the difference concerning the latitude of imperfect duties) with perfect duties remain, differences that may be relied upon to justify the claim that imperfect duties are less important than perfect duties. To begin with, Kant (in the Groundwork) views that which is contrary to strict (or perfect) duty as containing a contradiction in conception, whereas that which is contrary to wide (or imperfect) duty is understood to involve "merely" a contradiction of will. ${ }^{33}$ Thus, for example, acting on a maxim contrary to the duty to refrain from making false promises cannot even be conceived as a universal law. After all, if the maxim to make false promises whenever it suits one were to become a universal law, the very condition of promising, namely that the promisee believes the promisor will deliver on his promise, would disappear. ${ }^{34}$ By contrast, Kant argues that what is contrary to the imperfect duty of beneficence, for example, can very well be conceived as a universal law without contradiction: if the maxim to never aid those in need were to become a universal law "the human race could admittedly very well subsist, no doubt even better than when everyone prates about sympathy and benevolence and even exerts himself to practice them occasionally, but on the other hand also cheats where he can, sells the right of human beings or otherwise infringes upon it." 35

Kant does seem to argue here for the primacy of perfect duties over imperfect duties. He maintains that actions contrary to all duties contain a contradiction of will. But in the case of perfect duties, the maxim guiding actions contrary to duty cannot even be conceived as a universal law, "far less could one will that it should become such." ${ }^{36}$ A contradiction of will thus seems to be a less strict criterion than a contradiction in conception, allowing us to conclude that perfect duties enjoy primacy over imperfect duties. ${ }^{37}$ It follows from such primacy that the exercise of our imperfect duties is constrained by our perfect duties. In other words, I may not steal in order to be able to fulfill my duty of aid to the needy ${ }^{38}$

33. Kant. Groundwork. Ak 4:424.

34. Ibid. Ak 4:422.

35. Ibid. Ak 4:423.

36. Ibid. Ak 4:424.

37. Timmermann. Good but Not Required? 17. In Vigilantius's lecture notes, Kant even explicitly says as much: "So imperfect duties always succumb to perfect ones" (Kant, I. (1997). Lectures on Ethics. (P. Heath, Trans., P. Heath \& J. B. Schneewind, Eds.). Cambridge: Cambridge University Press. Ak 27:537).

38. O’Neill, O. (2002). Instituting Principles: Between Duty and Action. In M. Timmons (Ed.), Kant's Metaphysics of Morals: Interpretive Essays (pp. 331-347). Oxford: Oxford University Press. 342-3. Kant's categorical exclusion of the possibility that there may be occasions on which an imperfect duty ought to enjoy precedence over a perfect duty could be problematic, however. For surely I may, for example, use another's boat without her permission in order to save a person from drowning? The utilitarian Mill has no difficulty allowing for this possibility, even though he agrees that in general perfect duties enjoy primacy over imperfect duties (Mill. Utilitarianism. 200), but Kant rejects such a thought entirely. Yet, do we agree with Kant that the holder of the deposit in Theory and Practice ought to hand over the 
Nonetheless, this does not mean that imperfect duties are not important or that they can be viewed as merely optional excellences. After all, as Jens Timmermann points out, the first formulation of the Categorical Imperative deals with the question whether or not we can will our maxim to become a universal law. Both perfect and imperfect duties are thus duties of fundamental importance prescribed by the Categorical Imperative. ${ }^{39}$ It may be true that we can conceive of a world in which the maxim to never help those in need has become a universal law, but we cannot rationally will such a universal law (Kant himself acknowledges) "since many cases could occur in which one would need the love and sympathy of others and in which, by such a law of nature arisen from his own will, he would rob himself of all hope of the assistance he wishes for himself." $" 40$

There is another, important difference between perfect and imperfect duties (already briefly mentioned above): non-performance of perfect duties always results in demerit, or moral culpability, whereas non-performance of imperfect duties only results in demerit if it is the result of a maxim to never comply with the imperfect duty in question. Though this may appear to point toward a greater importance of perfect duties, it is instead simply a consequence of a difference in demandingness between the two types of duties. What is meant becomes clear when we compare the duties not to lie, steal, and assault with the duties to aid the poor, to care for one's family members and to contribute to the health of one's political community. The first three duties are perfect in nature: what is required is fully specified (one must refrain from lying, stealing and assaulting). To whom one owes these duties is equally clear, namely to everyone. Performance of all these perfect duties, furthermore, presents no problems: one can perform them all for all without encountering problems of human finitude. The latter three duties are instead imperfect: whom one must help, for example, and how one must go about it is left underdetermined. More importantly for the point at hand, one cannot possibly perform all one's imperfect duties: caring for one's elderly parents may inhibit one from volunteering at the local community center; donating to charities $a, b$ and $c$ may render it impossible to donate to

sum to the unknowing, wealthy and misanthropic heirs, even though the wretched holder of the deposit could very well use this sum to fulfill his duty of care towards his family in need (Kant, I. (1996). On the Common Saying: That May Be Correct in Theory, But Is of No Use in Practice. In M. Gregor (Ed. \& Trans.), Practical Philosophy (pp. 277-309). Cambridge: Cambridge University Press. Ak 8:286-7)? It seems there may indeed be cases in which imperfect duties ought to enjoy precedence over the requirements of perfect duty.

39. Timmermann. Good but Not Required? 17.

40. Kant. Groundwork. Ak 4:424. Cf. O'Neill. Towards Justice and Virtue. 194. 
charities $x, y$ and $z$. Lobbying to raise awareness of the injustices in the international garment industry will require so much time and effort that one becomes unable to similarly lobby to end EU agricultural subsidies. It thus becomes clear that it is impossible for one to perform all one's imperfect duties, as they are generally time and resource consuming, whereas nothing similar is the case for one's perfect duties. As O'Neill phrases it, perfect duties are enactable by all and for all, ${ }^{41}$ whereas imperfect duties are enactable by all but not for all. ${ }^{42}$ Due to the limits of human finitude we are all limited in the number of imperfect duties we can perform (as well as the extent to which we can perform them). ${ }^{43}$ The reason why the non-performance of imperfect duties does not always lead to moral culpability is therefore that, in contrast to perfect duties, human finitude renders it impossible for us to perform them all for all, and therefore not because they are somehow less important.

For they are important. The refusal to perform one's imperfect duties to others contains a contradiction of will, as no agent could wish to have the maxims underpinning such refusal - e.g., maxims to ignore the needs of others or to refuse to help whenever it is costly to oneself - be universalized. Kant himself saw this, but his explanation is in a sense still somewhat prudential in nature: one cannot wish such maxims to become universal laws as one might oneself one day be in need of the assistance of others. The consequences, however, are far greater, as O’Neill illustrates:

$[\mathrm{N}] \mathrm{o}$ vulnerable agent can coherently accept that indifference and neglect should be universalized, for if they were nobody could rely on others' help; joint projects would tend to fail; vulnerable characters would be undermined; capacities and capabilities that need assistance and nurturing would not emerge; personal relationships would wither; education and cultural life would decline. ${ }^{44}$

It may be true, as both Pufendorf and Mill have argued, that imperfect duties are not central to the preservation of the very existence of society, but they certainly

41. We are speaking here, of course, of universal perfect duties. Special perfect duties need not be performed by all for all. Instead, the special perfect duty to pay back a loan is performed by the person who received the loan for the person who lent it.

42. O'Neill. Towards Justice and Virtue. 148. This argument will be crucial in defining, in Chapter 4, our duties to the global poor as imperfect duties and, therefore, as duties of virtue.

43. This point is often stressed by Simon Hope. See for example Hope, S. (2013). Subsistence Needs, Human Rights, and Imperfect Duties. Journal of Applied Philosophy, 30(1), 88-100. 92-3.

44. O’Neill. Towards Justice and Virtue. 194. 
are crucial to its flourishing. Moreover, as I will argue throughout the dissertation, our imperfect duties form an important complement to our perfect, juridical duties, which, even when universally respected, cannot avoid injustices from arising. Legal systems and political institutions are never without their defects and will thus benefit greatly if subjects perform not only their strict duties, but also regularly perform their imperfect duties: "A legal order may gain support from forms of social solidarity and traditions of fair play; it may be undermined by traditions of greed or cruelty." 45

Finally, some point out that perfect duties have correlative rights whereas imperfect duties do not and would base their claim that imperfect duties are less important than perfect duties on this difference. They might ask: if the exercise of beneficence, for example, is so important why then is it not made a legal duty with correlative claim rights? Why do the indigent of the world not have a right to our aid but we do all have a right not to be tortured? Surely the answer must be that we find the duty to refrain from torturing more important than the duty to aid the global poor? To such charges I would respond that, firstly, one cannot (at least not on a Kantian account) state that all perfect duties have correlative rights. The duties of respect and to refrain from lying are two examples of such perfect duties without corresponding rights. Therefore, the presence or absence of corresponding rights does not justify the statement that all perfect duties are more important than all imperfect duties (as some perfect duties lack corresponding rights as well).

Secondly, and more importantly, the reason why imperfect duties do not have correlative rights has nothing to do with any lack of importance. Instead, their latitude renders them unclaimable, which as a consequence precludes any rights to their performance. ${ }^{46}$ Consider the duty to aid the poor. Who must do what for which indigent person(s) is not clearly prescribed by this duty, but rather left to the discretion of the agent. It follows that the person in need has no way of claiming assistance. From whom could she claim it? The problem with imperfect duties in this respect is thus that their latitude renders it difficult to pair up duty-bearers and right-holders. If it is not clear from whom we can claim the performance of a duty, we can no longer speak of a right to the performance of that duty. The absence of a corresponding right thus results from the latitude of imperfect duties, not from their lesser importance. 
Thirdly, the fact that certain duties do not have corresponding rights should not lead us to conclude that they are, therefore, less important. Yet, this is certainly a common assumption, especially in contemporary liberal political philosophy. The reason for this assumption is, or so I will argue in the following section, that rights are often considered to be the fundamental moral category as well as the adequate starting point for asking ourselves what we ought to do. In such a manner, it becomes tempting to view the scope of our duties as delimited by our rights (we have a right not to be tortured, so there is a duty not to torture; we have a right to have our property respected, so there is a duty not to steal, and so forth). All morally worthy actions beyond the scope of rights-based duties thus come to be seen as acts of supererogation, or optional excellences. As a consequence, imperfect duties, lacking corresponding rights, come to be viewed as less important. The assumption underlying this argument is that the most fundamental issues concerning morality can only be expressed in terms of rights and the perfect duties to which they give rise. The very idea that there may be matters of fundamental moral importance that cannot be captured with the language of rights is hereby dismissed out of hand. It will be one of the main points of this dissertation as a whole to demonstrate the deficiencies of this position - typical of the perspective of rights - and to assert instead the importance of imperfect duties and duties of virtue.

With the question of duties with and without correlative rights we have reached a natural bridge from the distinction between perfect and imperfect duties to the distinction between duties of justice (or duties of right, in Kant's terms) and duties of virtue, which will be discussed in the following subsection. But let us first sum up our findings thus far. We found that many ways of distinguishing perfect from imperfect duties still common today can be traced back to the work of Pufendorf (and, to a lesser extent, to Grotius): perfect duties are enforceable and have corresponding rights, whereas imperfect duties lack enforceability and corresponding rights; the content of perfect duties is clearly defined, whereas in the case of imperfect duties it is not clear who must do what for whom; non-performance of one's perfect duties results in demerit, whereas this is not the case for non-performance of imperfect duties; and perfect duties appear to be somehow of greater importance than imperfect duties. I believe all these characteristics can be found in contemporary accounts of the distinction.

By means of a discussion of Kant's more thorough examination of perfect and imperfect duties, I have taken issue against the thought, common especially in current liberal accounts of duties, that imperfect duties are less important 
and less binding than perfect duties. Accordingly, I have argued that the reason imperfect duties allow for latitude is not because they are less important, but rather because they prescribe maxims for actions instead of actions. This latitude, furthermore, does not imply that imperfect duties are somehow optional or less binding. Performing imperfect duties is not optional, only the manner in which one chooses to discharge them is; one can choose to fulfill one's duty in this manner or that, but to refrain from performing one's duty altogether is not an option and will result in moral culpability.

Furthermore, given that all duties (perfect and imperfect alike) are derived in the same fashion, namely from the first formulation of the categorical imperative, ${ }^{47}$ it seems odd to attach a greater moral weight to perfect duties, solely because maxims contrary to perfect duties result in a contradiction in conception whereas maxims contrary to imperfect duties result merely in a contradiction of will. What can be concluded, however, is that there is a primacy of perfect duties with respect to imperfect duties, that is, that the performance of our imperfect duties is limited by the requirements of our perfect duties.

But surely the fact that non-performance of perfect duties results in demerit whereas one incurs no moral guilt if one does not perform an imperfect duty, demonstrates that the latter duties are of lesser importance and are less binding (one may, after all, choose not to perform an imperfect duty without incurring moral guilt)? This, too, we denied by demonstrating that the reason why non-performance of imperfect duties does not (always) result in demerit is simply that, due to human finitude, they cannot be performed by all for all, in contrast to perfect duties.

Finally, imperfect duties' lack of correlative rights may be believed to prove that they are not as important. This argument relies on the assumption that everything of moral importance can be best formulated in terms of rights. As a consequence, duties without correlative rights appear less important. The notion that there may be matters of great moral importance that escape the language of rights is never taken into consideration: "Within frameworks that give priority to the perspective of recipience, so make rights the fundamental ethical category, it is hard to show how act-types that cannot be claimed as a matter of right can be either good or obligatory." ${ }^{8}$ Once we reject the assumption that rights are the fundamental normative category, we find that there is no immediate correlation between the 
absence of corresponding rights and a lesser moral weight of imperfect duties. An additional reason why imperfect duties lack corresponding rights is because their latitude renders them unclaimable, precluding any rights to their performance.

Upon closer examination, therefore, none of the differences between perfect and imperfect duties can justify the claim that the former are somehow of greater moral importance or more binding than the latter. In fact, I hope to show that imperfect duties are of crucial importance as supplement to the sphere of justice.

\section{§ 2.1.2 - Duties of Justice and Duties of Virtue}

One of the most central ideas Kant presents in The Metaphysics of Morals is that one ought to distinguish between duties that can be prescribed by external (i.e. juridical) laws and duties that cannot. ${ }^{49}$ One ought to distinguish, in other words, between duties of justice ${ }^{50}$ and duties of virtue. But on what basis does one differentiate between these two sets of duties? Allen Buchanan is right when he says that there is quite some confusion on this score. Scholars have varying understandings of this distinction, and often employ it without rendering it explicit, let alone providing an argument for it. ${ }^{51}$ Once again taking Kant's work on the subject as my guide, I hope to render perspicuous the difference between these two duties, which will have a central role to play in the remainder of this dissertation.

In addition, it should become clear how the distinction between duties of justice and duties of virtue relates to the distinction between perfect and imperfect duties discussed above. It should become apparent that the former distinction is not simply a reformulation of the latter distinction, though the two sets of duties are intimately connected. I shall retain that all duties of justice are perfect duties (and so that imperfect duties cannot be duties of justice), but that not all perfect duties are duties of justice.

In order to understand what duties of justice are, we must first understand what is meant by "justice." Similarly, we must first clarify the term "virtue" if we are to fully grasp the meaning of the concept "duties of virtue." Therefore, I will start by clarifying the distinction between justice and virtue before moving on to present the distinction between duties of justice and duties of virtue.

49. Kant. The Metaphysics of Morals. Ak 6:379, 6:239.

50. I shall refer to Kant's term Recht as "justice" (and, accordingly, to his Rechtspflichten as "duties of justice") as it is the term that is more commonly used in debates of political and legal philosophy, whereas the term "right" is largely limited to Kant scholarship.

51. Buchanan, A. (1987). Justice and Virtue. Ethics, 97(3), 558-575. 
With Kant, we can understand the sole concern of the sphere of justice to be the guaranteeing of equal spheres of freedom for all. In more Kantian terms, justice concerns the formal condition of external freedom, that is, "the consistency of outer freedom with itself if its maxim were made universal law." ${ }^{2}$ In order to secure such an equal measure of outer freedom for all, limitations must be placed on the freedom of each. This is what justice does: "Das Recht bestimmt die Freiheit des einzelnen relativ zu der Freiheit aller anderen und sichert durch den wechelseitigen Zwang die individuellen Freiheitsräume gegeneinander." 53

The sphere of justice contains its own action-guiding principle, namely the universal principle of justice: "Any action is right [i.e. just] if it can coexist with everyone's freedom in accordance with a universal law." ${ }^{54}$ It follows that if my action is indeed compatible with the external freedom of each, none may rightfully deter me from pursuing said action lest they do me wrong (Unrecht), as their hindrance of my rightful action is clearly not compatible with freedom in accordance with a universal law.

Yet, in particular cases Kant does justify certain limitations of freedom. He argues that when someone acts in a manner incompatible with the rightful freedom of another, his action is deemed a hindrance to freedom and thus wrong. It follows that coercing someone to refrain from such an unlawful act would itself be lawful, as such a limitation of that person's freedom renders it once more compatible with the freedom of everyone else. Or, as Kant puts it: a "hindering of a hindrance to freedom" is "consistent with freedom in accordance with universal laws." 55 Hence, justice carries within it the authorization to coerce those who threaten the balance of equal spheres of freedom through their actions. In fact, Kant goes so far as to state that "[r]ight [i.e. justice] and authorization to use coercion ... mean one and the same thing." ${ }^{6}$

Thus far we have seen that justice prescribes or proscribes certain actions in order to secure an equal distribution of freedom, and that it may use force to ensure compliance with its prescriptions. Next, we must clarify what falls beyond the scope of justice. Kant goes to great pains to exclude inner "actions" (such as the ends one adopts, or the motives from which one acts) from his definition of justice. Thus, immediately following his exposition of the universal principle of

52. Kant. The Metaphysics of Morals. Ak 6:380.

53. Horn, C. (2014). Nichtideale Normativität: Ein neuer Blick auf Kants politische Philosophie. Berlin: Suhrkamp. 14-5.

54. Kant. The Metaphysics of Morals. Ak 6:230.

55. Ibid. Ak 6:231.

56. Ibid. Ak 6:232. 
justice, he states that "it cannot be required that this principle of all maxims be itself in turn my maxim, that is, it cannot be required that I make it the maxim of my action." ${ }^{57}$ In other words, justice only demands that the subject's external actions comply with its universal principle; it does not additionally demand a particular disposition on the part of the subject to accompany that compliance. I do not diminish the freedom of another, even if I secretly wish to do so, so long as my external actions do not detract from his or her freedom. Justice does thus not require me to respect the freedom of another from the motive of duty; this is rather a matter of virtue (as we will see shortly). These thoughts lead to Kant's formulation of the universal law of justice: "so act externally that the free use of your choice can coexist with the freedom of everyone in accordance with a universal law." ${ }^{58}$ The difference with the categorical imperative should be clear. Whereas it commands the subject to make his or her maxims comply with a universal law, the universal law of justice merely requires the subject's actions to be in accordance with a universal law.

This brings us to the main difference between justice and virtue. As said, justice prescribes and proscribes certain outward actions in order to maintain a system of equal spheres of external freedom for all. It prescribes such actions, furthermore, with "mathematical exactitude." ${ }^{9}$ Since justice prescribes only specific external actions and it does so, furthermore, with great precision, it is able to ensure compliance with its commands by means of force. Virtue, by contrast, does not prescribe actions but rather ends, the adoption of which is presented as a duty. ${ }^{60}$ Where Kant explicitly excluded the adoption of ends from the sphere of justice, ${ }^{61}$ he now presents it as the core of virtue.

Since virtue prescribes not actions but ends, any kind of enforcement is ruled out, as I can be forced to perform (or refrain from performing) certain actions, but the adoption of ends is an inner matter, which is by definition beyond the reach of external coercion. It follows that the only constraint possible in the case of virtue is free self-constraint (Selbstzwang). ${ }^{62}$ Whereas one can act rightfully, that is, in accordance with the prescriptions of justice, from any motive whatsoever (outward compliance is, after all, all that matters), acting virtuously already implies that one acts from the correct motive. In other words, whereas 
justice cannot require any specific incentives for actions, virtue requires that one comply with its commands from the motive of duty.

Virtue requires that my subjective principles for acting, i.e. my maxims for action (not simply my actions), are in accordance with the objective ends (i.e., ends that are also a duty) prescribed by virtue. From this it follows that duties of virtue are imperfect, ${ }^{63}$ since virtue commands us to act in light of the end of promoting other people's happiness, for example, yet it leaves undetermined whose happiness specifically we ought to promote as well as the acts through which such promotion of happiness ought to be undertaken. This leaves the would-be virtuous agent with some considerable latitude, rendering duties of virtue imperfect.

Now that we have an understanding of both justice and virtue, we can undertake an exposition of the difference between their respective duties. Let us start with duties of justice.

1. Duties of justice concern clearly determined outward actions. ${ }^{64}$ Specifically, I take this to mean that it is clear who must do what for whom. Therefore, duties of justice are narrow, ${ }^{65}$ or perfect ${ }^{66}$ duties.

2. Because of their determinateness, our actions can easily be judged either in compliance with or in violation of duties of justice. This makes it possible to claim and enforce compliance with duties of justice by means of an external legislation. ${ }^{67}$

3. From their enforceability, it follows that duties of justice can have corresponding rights. ${ }^{68}$ This means that the performance of a duty of justice is owed ${ }^{69}$ to the holder of the corresponding right and that a violation of one's duty of justice wrongs ${ }^{70}$ the right-holder, that is, violates her right.

63. Ibid. Ak 6:390.

64. See, e.g., Kant. The Metaphysics of Morals. Ak 6:388.

65. Ibid. Ak 6:390, 6:410.

66. Ibid. Ak 6:240.

67. Ibid. Ak 6:239, 6:379, 6:394, 6:410.

68. Ibid. Ak 6:383.

69. It is not for nothing that Kant refers to duties of justice as "officium debiti" (ibid. Ak 6:390). Furthermore, since they are owed, their performance is in no way meritorious.

70. I find Joel Feinberg's distinction between "harming," understood as causing a setback to another's interests, and "wronging," understood as a "violation of one's rights, or an injustice," quite helpful (Feinberg, J. (1984). The Moral Limits of the Criminal Law. Volume One: Harm to Others. New York: Oxford University Press. 107). A person may be harmed without being wronged, that is, without her rights being violated. For example, if I trip and inadvertently bumb into the person in front of me, causing her to fall down, I may have harmed her, but I have not violated her rights and thus have not wronged her. When I employ the noun "wrong" (or the verb "to wrong") I similarly intend a violation of rights. 
4. Furthermore, duties of justice not only can but also must be enforced, because actions in violation of such duties are incompatible with freedom in accordance with a universal law, that is, such violations endanger the very function of justice, which is to ensure equal shares of external freedom for all.

5. Finally, given that justice is concerned solely with our outward actions, it is characterized by what Wolfgang Kersting has called a "Gesinnungsindifferenz." 71 The motive from which one fulfills one's duties of justice is thus entirely irrelevant. ${ }^{72}$

Duties of virtue differ from duties of justice on each of these points.

1. Duties of virtue do not prescribe clearly defined actions, but rather command us to adopt ends "by incorporating them into our maxims and to advance them in practice when the occasion arises." 73 Duties of virtue are, therefore, wide, or imperfect duties. ${ }^{74}$

2. Therefore, it is not possible to say when one has fulfilled one's duty of virtue, because duties of virtue do not prescribe who must do what (and how much) for whom. As a consequence, duties of virtue are not claimable. For if a duty does not prescribe who must do what for whom, then how can anyone claim anything from anyone else? Where could one lodge one's claim? And what, precisely, would one claim? From their unclaimability follows the impossibility of their enforcement through external coercion. Instead, duties of virtue must rely on free self-constraint.

3. Consequently, duties of virtue have no corresponding rights to coerce. This means that the performance of a duty of virtue is not owed to another. Non-performance of my duty of virtue, therefore,

71. Kersting. Kant über Recht. 221.

72. Kant. The Metaphysics of Morals. Ak 6:231. Of course, the incentive can be of import when the prescriptions of justice are not followed. Kant recognizes this when he distinguishes fault from crime: "An unintentional transgression which can still be imputed to the agent is called a mere fault (culpa). An intentional transgression (i.e. one accompanied by consciousness of its being a transgression) is called a crime (dolus)" (ibid. Ak 6:224; cf. 6:228). Thus, in the case of a transgression of the law it may indeed matter a great deal what one's incentive was (whether one meant to break the law, did so from necessity, or did so unintentionally), as is recognized, for instance, in the distinctions between murder, voluntary manslaughter and involuntary manslaughter. However, in the case of behavior in compliance with the law, the incentive for compliance is irrelevant.

73. Timmermann. Kantian Dilemmas? 45.

74. There are some exceptions to this general statement, however, at least for Kant. For example, the duty not to lie, the duty not to commit suicide, and the duty of respect are strict, i.e. perfect, duties of virtue. 
does not result in my wronging anyone. For example, person $A$ may not claim from person $B$ that $B$ perform an act of beneficence towards $A$, nor may $A$ complain that her right has been violated if $B$ does not help her.

4. Not only can duties of virtue not be enforced, they may not: for Kant, the line separating justice from virtue also indicates the boundaries of legitimate state power. Having the state enforce compliance with duties of virtue, as if they were duties of justice, runs contrary to Kant's very intention of separating the two realms from each other and reeks of paternalism: "die Tugend ist nicht Sache des Staates."75

5. Finally, Kant often defines duties of virtue as requiring a special motive; not only do duties of virtue require us to act in light of certain ends, but they, moreover, demand we do so from the motive of duty. In short, duties of virtue require from us a virtuous disposition. ${ }^{76}$ The fact that duties of virtue involve the adoption of ends and acting from a particular motive is, incidentally, another important reason why they cannot and may not be enforced.

Having thus expounded the distinction between duties of justice and duties of virtue, we can end our discussion of this distinction by briefly assessing the relation between it and the perfect-imperfect distinction. There are many similarities between perfect duties and duties of justice on the one hand, and imperfect duties and duties of virtue on the other. In fact, there are but two differences. Firstly, the motive from which one acts does not play a role in distinguishing perfect from imperfect duties, whereas it does in separating duties of justice from duties of virtue. Secondly, the imposition of duties of justice serves the explicit purpose of securing equal spheres of freedom for all. Perfect duties, by contrast, serve no such purpose. Instead, a duty's perfection only tells us something about its strictness. The two terms are, therefore, not synonyms. In fact, there are, on Kant's account, several perfect duties that are not duties of justice, precisely because they do not serve the function of preserving equal freedom (as in the

75. Kersting. Kant über Recht. 221n. Cf. Wood, A. (2002). The Final Form of Kant's Practical Philosophy. In M. Timmons (Ed.), Kant's Metaphysics of Morals: Interpretive Essays (pp. 1-21). Oxford: Oxford University Press. 10: "any use whatever of social coercion in any form to enforce ethical duties ... must be regarded as a wrongful violation of individual freedom by corrupt social customs."

76. See, e.g., Kant. Vorarbeiten und Nachträge. Ak 23:251: "Äußere Pflichten sind die der Leistungen (ihrer Wirkung nach). Innere Pflichten sind die der Gesinnungen." 
case of the perfect duty of virtue not to $\mathrm{lie}^{77}$ ) or because they require a virtuous disposition (as in the case of the perfect duty of virtue of respect ${ }^{78}$ ).

Therefore, though we cannot simply equate the two sets of duties, we can say that duties of justice are always perfect duties ${ }^{79}$ and that imperfect duties are never duties of justice. Duties of virtue are mostly imperfect, though there are some exceptions.

As may be expected, given this close relation, the same prejudices exist with regard to duties of virtue that exist regarding imperfect duties. Here, too, the latitude of duties of virtue, their lack of corresponding rights, and the fact that non-performance does not amount to wrongdoing, are taken as signs that duties of virtue are less binding, that is, merely optional, and not as important as duties of justice. Having provided a point-by-point refutation of this view with regard to imperfect duties, we may forgo rehashing those arguments with regard to duties of virtue, given the strong similarities between these two sets of duties. The remainder of this dissertation will, furthermore, provide ample opportunity for demonstrating that duties of virtue are of crucial importance and that the sphere of justice, in fact, depends on their regular performance. The next subsection will provide the first such argument.

\section{$\S$ 2.1.3 - The Relation Between Justice and Virtue}

Following the previous subsection, in which we have expounded the differences between the spheres of justice and virtue as well as between their respective duties, the impression could arise that these two realms of morality are fully independent from one another. Indeed, at times it seems Kant wishes to hermetically seal off each of these two spheres from the other, as Wolfgang Kersting has

77. As a matter of justice, lying is prohibited only if the lie results in a violation of the rights of another (Kant. The Metaphysics of Morals. Ak 6:238n), but ethics is not limited by this condition of harmfulness (ibid. Ak 6:429). However, in On a Supposed Right to Lie from Philanthropy Kant states that one does wrong (Unrecht) by lying, though not to the person one lies to, but rather to humanity generally, as by lying "I bring it about ... that statements (declarations) in general are not believed, and so too that all rights that are based on contracts come to nothing an lose their force" (Kant, I. (1996). On a Supposed Right to Lie from Philanthropy. In M. Gregor (Ed. \& Trans.), Practical Philosophy (pp. 611-615). Cambridge: Cambridge University Press. Ak 8:426). Thomas Mertens elaborately examines this point in Mertens, T.J.M. (in press). On Kant's Duty to Speak the Truth. Kantian Review.

78. Ibid. Ak 6:462-4. The duty of respect is not a duty of justice, for the free adoption of the maxim of respect is an inner matter, which escapes the reach of external coercion (cf. Sensen, O. (2013). Duties to Others From Respect (TL 6:462-468). In A. Trampota, O. Sensen \& J. Timmermann (Eds.), Kant's 'Tugendlehre': A Comprehensive Commentary (pp. 343-363). Berlin: Walter de Gruyter. 358). 
noted: "Die Grenze zwischen Recht und Ethik ist in beiden Richtungen unüberschreitbar." ${ }^{80}$ At times, Kant even speculates about a sphere of justice that is fully independent from virtue, "not mingled with anything ethical," requiring "only external grounds for determining choice," and that is "completely external." 81 In the present subsection I, therefore, wish to examine the relation between justice and virtue, as presented by Kant. Kant's understanding of this relation (or lack of relation, rather) is exemplary for the position I wish to reject - so common for much of liberal political thought -, namely that all that is needed to maintain a political community is just laws and institutions backed up by force, i.e. justice, rendering a virtuous citizenry redundant. Pace Kant, I will argue that justice and virtue cannot be so neatly separated as his conceptual distinction suggests. Rather, justice depends on virtue. In order to make this claim, I will illustrate how widespread virtue ensures the stability of a political community and functions as a complement to justice.

Justice requires no virtuous disposition from us. It cares not what the nature is of the motive from which we act. We may act from respect for the law or from mere prudential reasons; so long as my actions do not detract from the external freedom of others, I have acted justly. Kant thus limits the scope of justice to the prescription (and proscription) of external actions, which one may be forced to perform. Where virtue relies on the subject legislating for herself and freely constraining herself to perform her duties, justice relies on an external lawgiving and coercion; it ensures we all perform our duties by means of force. Justice is not interested in questions of motives or dispositions - in fact, it ought to be indifferent concerning such matters. It does not require me to respect the freedom of others from the motive of duty; that would rather be a matter of virtue. Justice, in short, does not require goodness, or good character, but merely outward compliance.

The intimate connection between justice and coercion means that the incentive for action can cease to be insight into and respect for the law - motives on which virtue must rely - and be replaced by the merely prudential incentive to avoid being coerced. The "emancipation" of justice from the disposition of the subject ${ }^{82}$ means that justice requires no ethical motivation at all and can, instead, 
rely solely on external coercion. Whereas ethical coercion consists in constraining oneself through the idea of duty, the coercion typical of the sphere of justice is instead characterized as pathological, by which Kant means that juridical coercion appeals to aversions, "for it [juridical lawgiving] is a lawgiving, which constrains, not an allurement, which invites." ${ }^{33}$

We might add that by substituting free self-constraint with external coercion (or rather with the incentive to avoid external coercion), it would appear that the process of autonomous decision-making we know from Kant's moral writings has become superfluous in the case of compliance with the prescriptions of justice. Recall that in the Groundwork and the second Critique true moral worth was said to reside only in actions performed from the motive of duty, and not in those performed merely in conformity with duty. ${ }^{84}$ By dropping this requirement, justice, in contrast with virtue, allows for a heteronomous determination of choice (Willkür). On Kant's account, therefore, justice, understood as the protection of individual spheres of external freedom by means of reciprocal coercion, realizes its own preservation through heteronomous regulation. ${ }^{85}$

This is where Kant's account of justice, specifically his rigorous exclusion of any trace of virtue from the sphere of justice, becomes problematic. Allen Wood describes the problem well: "a civil society based on right requires no moral commitment on the part of its members to respect one another's rightful freedom. It requires only a system of external legislation, backed by coercive sanctions sufficient to guarantee that rights will not be infringed." ${ }^{6}$ Wood, however, does not recognize any problem here and this passage in fact states his agreement with Kant. Many other Kant scholars and most contemporary liberal political philosophers agree with Kant's position as well. ${ }^{87}$ So what is the problem?

The sphere of justice is concerned, as said, with the securing of equal shares of freedom for all. Political institutions and legal systems are tasked with realizing this ideal of justice. According to Kant, the only thing such institutions demand is outward compliance, regardless of the motive from which such compliance springs. All that is required to obtain such compliance is the threat or actual use of force. When external coercion is present, such things as free self-constraint and 
acting from the motive of duty thus become redundant. ${ }^{88}$ Even when Kant speaks of the progress of the human race towards a state of peace between nations and ultimately the realization of a truly cosmopolitan society, he maintains that this in no way calls for an enlargement of the "moral foundation in humanity," but will instead be a product of sheer legality ${ }^{89}$ that is, mere conformity of one's actions with the prescriptions of duty. In other words, the progress of mankind towards Kant's political ideal does not require any advance in the morality of men and women, but only outward compliance, or legality.

To be clear, it is understandable that Kant wishes to exclude agents' motives and ends from the sphere of justice. Firstly, motives and ends are internal matters and therefore beyond the reach of external coercion. In other words, even if a state would wish to force its citizens to act from particular motives and in light of certain ends, it would not be able to do so. Secondly, Kant would view the attempt to use external coercion in order to influence citizens' reasons for acting as paternalistic, and rightly so (imagine a police force patrolling the streets looking for signs that citizens are respecting the law but begrudgingly).

It is, therefore, clear that one cannot force citizens to act from respect for the law, and that the very attempt to do so reeks of paternalism and is, as such, a violation of liberal neutrality (as we would call it nowadays). However, from the exclusion of citizen's motives for acting from the list of legitimate goals of external coercion, it does not follow that justice does not need good motives. Quite the contrary: political institutions and legal systems cannot be expected to remain stable and persist over time if a majority of the agents acts from prudential motives alone, that is, simply to avoid punishment. The problem is, thus, as follows:

[E]ven though the law cannot and must not require ethical motives and voluntary compliance out of respect for the law, the rule of law, a rightful condition, cannot be fully realized in a society in which people, on average, are not ethically motivated to respect the law for its own sake. ${ }^{90}$

88. Next to ample textual evidence in The Metaphysics of Morals, one can already find this position in Kant's Review of Hufeland's "Essay on the Principle of Natural Right" (in M. Gregor (Ed. \& Trans.), Practical Philosophy (pp. 113-117). Cambridge: Cambridge University Press. Ak 8:128.

89. Kant, I. (1996). The Conflict of the Faculties. In A. Wood \& P. Guyer (Eds.), M. Gregor \& R. Anchor (Trans.), Religion and Rational Theology (pp. 237-327). Cambridge: Cambridge University Press. Ak 7:91-2.

90. Willaschek, M. (2009). Right and Coercion: Can Kant's Conception of Right be Derived from his Moral Theory? International Journal of Philosophical Studies, 17(1), 49-70. 58. 
The problem with Kant's strict separation of justice and virtue is thus an empirical one: as a matter of fact, legal systems and political institutions do rely on at least a majority of the people acting in accordance with the law from respect for the law. Kant does not seem to acknowledge this fact, however. Whereas virtue requires autonomy - i.e. requires that the subject perform her duties from respect for the moral law - Kant seems to say that for the sphere of justice a mere heteronomous subject will suffice, a subject who acts strictly from self-interest and whose sole reason for not violating his duties is simply to evade punishment (or perhaps some other prudential reason). But is a state containing solely such heteronomous subjects tenable? Can we expect a legal system to last that relies exclusively on the external coercion of its subjects for compliance with its laws? Does not rather every Rechtsstaat depend on its citizens being motivated to act in accordance with its laws even when the incentive characteristic of justice, i.e. external coercion, ${ }^{91}$ is absent?

The answer I would venture is that if all citizens were to decide not to abide by the law whenever punishment is likely to remain absent, the rule of law would not be secure. In other words, any legal system and any political community would be in a precarious state if the majority of the people does not act in accordance with the law from the inner motivation of duty. ${ }^{92}$ For what if the threatened sanctions prove to be insufficient? What if the political and legal order itself would temporarily break down? What if one could somehow evade punishment? Kant would have to accept that in such cases, in which external coercion does not suffice or is not functioning properly, the agent does not consider herself bound to fulfill her duties. ${ }^{93}$

In practice, justice and virtue cannot be so neatly separated as their conceptual distinction suggests. Justice depends on virtue, because it relies on agents acting from the correct disposition. It is true enough that, as Kant rightly points out, such a disposition cannot be obtained by force. It follows that the sphere of justice relies on something, which it may not demand, namely compliance motivated by duty. Justice requires good character, or civic virtue, but may not demand it. Yet, a government may employ other means besides external coercion in order to bring about a good disposition. It may not use coercion to make its

91. Kant. The Metaphysics of Morals. Ak 6:220.

92. Note how this point is quite similar to the argument for the necessity of "voluntary self-obligation," made by Hans Küng (who was instrumental in the drafting of the UDHRe). He argues that legal coercion alone is not enough for the realization of human rights, which instead also requires the normative motivation of agents.

93. Horn. Nichtideale Normativität. 158. 
citizens virtuous, but it may encourage and nurture the flourishing of virtue in different ways. These matters will be elaborately discussed in Chapter 5 .

Next to the dependence of just laws and institutions on what we may call civic virtue, an analysis of our duties to the global poor provides us with another example of how the sphere of justice depends on virtue, thus demonstrating the great importance of duties of virtue. Imagine an owner of a clothing factory in Bangladesh. His factory is in compliance with all his country's labor and work safety laws, the people working for him do so freely (they are not forced by the factory owner to work in his factory), Western clothing companies buy wares from this factory owner through lawful transactions, and I, finally, obtain a sweater from that company by buying it in a store in Amsterdam. Strictly speaking, nobody in this example has wronged anyone else. That is to say, there have been no violations of duties of justice. Still, the net result of this global web of relations is abominable: countless people working extremely long hours for less than a living wage in terrible (and at times fatally dangerous) circumstances.

This example demonstrates that often it is not enough to merely insist on the performance of duties of justice. In situations where institutional schemes or sets of laws are flawed (which will nearly always be the case), the performance of our duties of justice does not suffice and other duties are required to fill the gaps. These duties can assume various forms, but may be summarized as duties to aid those in need and duties to push for reform of the prevailing institutions that are (partially) responsible for that need. As will be extensively argued in Chapter 4, these duties take the form of imperfect duties - after all, whom I must aid, how much I ought to give, and to which cause specifically I should donate my time and money, is all left to my discretion -, and are therefore duties of virtue. The fact that our duties to the global poor are chiefly duties of virtue, however, is not at all to say that these duties are less important or merely optional excellences. Instead, duties of virtue are shown to be of paramount import as they function as a necessary and indispensable complement to the sphere of justice. Furthermore, the manner in which one discharges one's duty of virtue toward the global poor may allow for a certain measure of discretion, but one is obligated to do something. Doing nothing at all to aid the global poor is not a morally acceptable option (provided, of course, one has the means to supply such aid ${ }^{94}$ ). 
In conclusion, Kant's distinction between duties of justice and duties of virtue is accurate, but his strict separation of justice and virtue runs into problems. Their conceptual distinction should not lead us to think that they are fully independent from one another. Rather, justice and virtue constitute interdependent realms of morality, as the presence of just laws and institutions facilitates the performance of virtue, and widespread virtue ensures stability in a political community and functions as a complement to justice. The position that duties of virtue are somehow less important than duties of justice must, therefore, be rejected. The treatment in Chapters 4 and 5 of our duties to the global poor and our civic duties respectively will further illustrate the significance of duties of virtue. Indirectly, this will function as a criticism of the rights-based perspective on morality - which views rights as the fundamental moral category and derives all our duties from our rights -, as duties of virtue tend to appear less important or to recede from view entirely when one employs such a perspective (as will be illustrated in the following section).

\section{§ 2.2 - On Rights}

At the very beginning of the previous section, we broadly defined duties as actions to which one is bound; duties thus limit one's freedom of choice. This section deals with rights and will broadly hold that rights concern that part of morality concerned with the question when one person is morally justified in binding the freedom of another by prescribing how she should act. If one has a right, then one has a moral title to bind the freedom of another by claiming the performance of a duty from her. Having a right thus involves a Hohfeldian power over the duty of another, which one can either claim or waive. Given this understanding of rights, I will hold duties of justice to be indicative of rights - and universal duties of justice to be indicative of human rights -, as only duties of justice are claimable and can therefore possess corresponding rights (in contrast to duties of virtue). In identifying rights, I therefore propose we adopt what I shall call the perspective of duties, that is, that we start from duties and proceed to identify our rights, instead of the more common perspective of rights, whereby one starts by identifying rights independently of duties and from there proceeds to define the corresponding duties. The reason I propose we adopt the perspective of duties instead of the perspective of rights is that the latter has detrimental consequences both for our duties and for our rights. 
Regarding the undesirable consequences for our rights, §2.2.1 will show how a typical approach starting from human rights with little attention for the corresponding duties - the interest theory - results in a proliferation of unclaimable human rights and thus in a weakening of human rights discourse as a whole. We can prevent this outcome by adopting instead the perspective of duties, which will allow us to identify human rights (as well as rights in general) more precisely by developing a clear criterion for (human) rights: only where there is a duty of justice, can there also be a (human) right. In developing this approach to rights, it would seem I align myself with the will theory of rights, as this theory views the ability to exercise some measure of control over the performance of the correlative duty as essential to the possession of the right.

Next, §2.2.2 will demonstrate how those who adopt the rights-perspective cannot recognize any duties beyond rights-based duties, that is, duties of justice. Any actions beyond those owed as a matter of justice are, consequently, viewed as merely optional excellences, or supererogatory acts. The perspective of rights thus leads to an impoverishment of our understanding of morality, limiting it to matters of justice alone.

\section{§ 2.2.1 - What Are Rights?}

The present subsection will provide a brief discussion of the will and interest theories of rights in order to clarify what a right is. By pointing out two problems with the interest theory of rights that are relevant to the more general concerns of this dissertation - namely the disadvantages of a rights-perspective on morality and the importance of a renewed emphasis on our duties -, I will finally side with the will theory of rights. Accordingly, I will present the claimability of rights as their existence condition. Genuine human rights will, therefore, be held to exist only when they are matched by universal duties of justice that fall on all others, for only then can each right-holder claim the corresponding duties from all duty-bearers.

Instead of taking human rights as our point of departure - by, for example, identifying fundamental human interests and subsequently drawing up a list of human rights to have those interests respected, protected and fulfilled - I will take duties as my starting point for identifying rights. That is, I will argue that only where there is a possible duty of justice can there also be a right. I will thus take duties of justice to be, as it were, indicative of rights. 
The thought that rights exist only where there is a duty of justice makes sense once one considers what rights do. What is the function of rights in normative discourse? What does it mean to have a right? Kant understood rights to be "(moral) capacities for putting others under obligations (i.e. as a lawful basis, titulum, for doing so)." 95 In the Vorarbeiten to the Doctrine of Right Kant repeatedly stresses this point. My having a right against another person corresponds to a debt on his or her part. ${ }^{96}$ The metaphor of the debt illustrates that rights bind those against whom the right is claimed, limiting their freedom. The debt must first be paid. To be sure, both duties of justice and duties of virtue entail having one's freedom of choice limited by a law: "The very concept of duty is already the concept of a necessitation (constraint) of free choice through the law." 97 Yet, they differ with regard to who may limit one's freedom. The law limiting free choice, as Kant puts it, may be of either a moral or of a legal nature. In the case of the former, my freedom of choice can only be limited by free self-constraint, in which case we speak of duties of virtue. In the case of a juridical law, however, my freedom of choice is instead limited by the right of another, in which case we speak of duties of justice. Thus, in the case of a duty of justice there corresponds a right of another "to coerce someone," ${ }^{8}$ whereas duties of virtue do not give rise to any such correlative rights on the part of others.

Similarly, H.L.A. Hart (who will here figure as representative of the will theory) maintains that rights belong "to that branch of morality which is specifically concerned to determine when one person's freedom may be limited by another's." In nearly a literal echo of Kant, Hart explains that "to have a right entails having a moral justification [i.e. the titulum, or title, of which Kant speaks] for limiting the freedom of another person and for determining how he should act." ${ }^{\prime 9}$ More specifically, rights determine what actions another may be forced, by means of "coercive legal rules," to perform or forbear. ${ }^{100}$

But when is it that the freedom of another may be legitimately limited? Regarding this question there are, broadly speaking, two schools of thought: the

95. Kant. The Metaphysics of Morals. Ak 6:237.

96. Kant. Vorarbeiten und Nachträge. Ak 23:344.

97. Kant. The Metaphysics of Morals. Ak 6:379.

98. Ibid. Ak 6:383.

99. Hart, H. L. A. (1955). Are There Any Natural Rights? The Philosophical Review, 64(2), 175-191. 183. Despite the divide between the interest theory and the will theory of rights, to be expounded presently, representatives of both theories can agree on this point. The examples of Kant and Hart illustrate that the will theory of rights agrees with the general point that rights function as entitlements to place duties on others. In the work of Joseph Raz, we can find evidence that the interest theory supports this thought as well: a special feature of rights is "the fact that they are sufficient to hold people to be bound by duties" (Raz, J. (1986). The Morality of Freedom. Oxford: Oxford University Press. 192).

100. Hart. Are There Any Natural Rights? 177. 
interest theory and the will theory of (human) rights. The former theory holds that human rights exist if a particular human interest is sufficiently important to justify the imposition of duties on others to respect, protect and fulfill this interest. A person $p$ thus has a right $r$ to have a particular interest $i$ respected, protected and fulfilled if and only if $i$ "is a sufficient reason for holding some other person(s) to be under a duty." ${ }^{101}$ Thus, according to the interest theory, the freedom of another may be limited in order to protect and further a sufficiently weighty human interest. By contrast, the will theory holds that the only legitimate reason for limiting the freedom of others is to maintain a system of equal freedom, that is, "an equal distribution of restrictions and so of freedom" among persons. ${ }^{102}$ In this regard, too, Hart proves himself to be a follower of Kant, as Kant had defined that branch of morality to which rights belong - namely, Recht, or justice - as the "sum of the conditions under which the choice of one can be united with the choice of another in accordance with a universal law of freedom." 103

Briefly put, interest theory holds that rights protect certain interests, whereas will theory maintains that rights protect equal spheres of freedom. It is beyond the scope of this section to discuss in full the intricacies of the debate between these two theories of (human) rights, so I will limit myself to discussing two main problems with the interest theory that are relevant to one of the overarching themes of this chapter, namely the problems with an exaggerated focus on rights in normative discourse and the concomitant neglect of duties. First, there is the problem of unclaimable rights. According to the interest theory, my having a human right, which is grounded by a sufficiently strong interest, means that someone somewhere bears the corresponding duty. Who this is, is not necessarily immediately clear, but this does not detract from the existence of the right, according to this theory. Raz gives the example of children's right to education: even if I do not know who has what duties regarding the right to education, this does not mean the right of every child to an education does not exist. It exists, because the interest of every child in receiving an education is of fundamental importance and, therefore, a ground for duties. ${ }^{104}$ Though this argument possesses a certain intuitive appeal - who, after all would wish to deny a child an education? -, it actually results in a weakening of rights. Most 
scholars would agree that one typical characteristic of rights is their peremptory force: the assertion of a right is not just another consideration to take into account, but a particularly weighty one that, in principle, cuts off further debate concerning what is to be done. ${ }^{105}$ Yet, the interest theory, represented here by Raz, is willing to accept rights even though we do not know who bears what duties towards whom. As a consequence, Raz's argument "leaves us with no specific individuals against whom our right will possess peremptory force."106 As a result, Raz's theory has the effect of loosening "the bonds of correlativity linking rights to duties." 107 The understanding of rights as granting a moral title to limit the freedom of another, i.e. to place duties on others, is therefore put at risk by the interest theory.

A typical consequence of the recognition of unclaimable rights as genuine rights is the shift in meaning of the concept "duty of justice." In our discussion in the previous section we found that only duties of justice correlate with rights. Such duties, furthermore, can only be perfect duties, as they require determinateness to be claimable. Recently, however, several scholars (who do not necessarily self-identify as interest theorists) have argued that even if the correlative duties have not been clarified and allocated to specific duty-bearers, the duties in question may still be duties of justice, albeit unclaimable and imperfect duties of justice. ${ }^{108}$ Yet, the very concept of an imperfect (and therefore unclaimable) duty of justice is a contradiction in terms, for if there is a right, then there is also a duty of justice, the performance of which is owed to the right-holder and the non-fulfillment of which constitutes a wrong to her (the right-holder), that is, a violation of her right. But if the duty is indeterminate and one can therefore not know who must do what for whom (as is the case with imperfect duties), how can we then speak of one person's right being violated by another? Who would be wronging whom? It follows that there is no such thing as an imperfect duty of justice, nor can the right supposedly correlating with such imperfect duties be held to exist. Yet, this seemingly obvious conclusion becomes more difficult to reach when the concept of rights no longer involves the power to claim or waive the performance of the correlative duty, as is the case with the interest theory

105. Though, as has already become apparent in the previous chapter, rights can obviously not be understood as trumps, as Dworkin held, enjoying precedence over all other considerations. Public health, public morals, and public order, e.g., can at times limit or overrule the force of rights.

106. Simmonds, N.E. (1998). Rights as the Cutting Edge. In M.H. Kramer, N.E. Simmonds \& H. Steiner, $A$ Debate Over Rights: Philosophical Enquiries (pp. 113-232). Oxford: Oxford University Press. 204.

107. Ibid. 205.

108. See, e.g.: Ashford. The Inadequacy of our Traditional Conception. 234; Stemplowska. Real World Duties. 482 . 
which holds that the existence of a duty-grounding interest is enough to be able to speak of a right to said interest.

Will theory, by contrast, maintains that we cannot speak of rights if the purported right-holder does not have some measure of control over the performance of the correlative duty. Therefore, if, as in the example of children's education sketched by Raz, the duty-bearers are unknown, there is no right, as it becomes impossible to exercise control over the correlative duty if one does not know who the duty-bearers are. Put in more general terms, unless one has the option of claiming or waiving the duty correlative to the right, one does not count as a right-holder. Having a right thus includes the possession of a Hohfeldian power over the duty of another, which one can either claim or waive. Accordingly, Hart speaks of the right-holder as a "small scale sovereign" who has exclusive control over another person's duty. ${ }^{109}$ The concept of unclaimable rights, though acceptable to interest theorists, is thus a contradiction in terms for will theorists.

As a consequence, rights as understood by the will theory have more bite to them than rights as understood by interest theorists, thus preserving the typical peremptory force of rights. Conversely, simply determining rights on the basis of the importance of certain interests, without any attention to the correlative duties, can leave interest theorists with unclaimable and therefore weak "rights." This first problem with the interest theory leads us directly to the second: the proliferation of human rights. Due to the fact that, according to the interest theory, the identification of an interest is enough to be able to speak of a right - even though there is not yet any clarity concerning the content of its correlative duties nor concerning the identity of the duty-bearers - it becomes easier to speak of human rights, resulting in human rights inflation. Interest theorists themselves admit that they use the term "right" in a wider sense, that is, that their understanding of the concept "right" allows them to identify more rights. ${ }^{110}$ Often, they seem to view this as an advantage of their approach, ${ }^{111}$ seemingly not quite realizing the significant downside, namely the devaluing of the status of all human rights, causing human rights discourse to become "increasingly vacuous." 112 Saying something constitutes a human right has thus become merely a way of saying that it is something (an interest, value or benefit) that deserves

109. Hart, H.L.A. (1982). Essays on Bentham: Jurisprudence and Political Philosophy. Oxford: Oxford University Press. 183.

110. See, e.g., Raz. The Morality of Freedom. 249.

111. See, e.g., Tasioulas. The Moral Reality of Human Rights. In Chapter 4 we will further explore the human right to an adequate standard of living, which Tasioulas defends in this text, and the problems that arise when one identifies rights without paying attention to the correlative duties.

112. Simmonds. Rights as the Cutting Edge. 215. 
our attention and consideration in normative reasoning, something, moreover, that must be balanced with a multitude of other relevant interests that merit our consideration.

Indeed, Raz says as much. Though he explicitly states that rights occupy a special place in normative discourse due to their peremptory force, ${ }^{113}$ his approach to rights as a whole undermines this force. According to Raz, "X $\mathrm{X}$ has a right' if and only if X can have rights, and, other things being equal, an aspect of X's well-being (his interest) is a sufficient reason for holding some other person(s) to be under a duty." 114 Similarly, he maintains that rights ground duties, a "ground which, if not counteracted by conflicting considerations, justifies holding that other person to have the duty." 115 Instead of asserting at least the prima facie peremptory force of rights, the interest theory thus reduces rights to one consideration among many others. Rights simply indicate important interests that are to be taken into account along with a plethora of other competing interests. Rights do thus no longer logically entail duties. Rather, they are taken into consideration in an intricate process of balancing multiple interests, at the end of which the right might come out on top, or it might not. In this manner, the peremptory force that sets rights apart in normative discourse is steadily eroded by the interest theory.

In sum, the first problem with the interest theory is caused by a lack of attention for the corresponding duties of human rights, which has led to the problem of unclaimable rights. Such unclaimable rights, by contrast, are an impossibility for will theorists, as possession of a right entails some measure of control over the performance of the correlative duty, which the right-holder must be able to claim from the duty-bearer. The second problem of the interest theory is the proliferation of human rights. Given that the identification of a sufficiently weighty interest suffices to speak of a human right, without considering the correlative duties, the interest theory is able to recognize far more human rights than the will theory. However, this comes at the great cost of weakening all human rights. This weakness stems, on the one hand, from the unclaimability of certain purported human rights (damaging the credibility of all human rights discourse) and, on the other hand, from the loss of the peremptory force of (human) rights as a consequence of the reduction of (human) rights to merely one factor among many to take into consideration. The will theory avoids these problems by in- 
sisting on claimability as existence condition of (human) rights, which allows it to preserve the peremptory force of (human) rights. Accordingly, I will hold a genuine human right to exist when it is matched by universal duties of justice that fall on all others. It is in this sense that duties of justice are indicative of rights, as announced at the outset of this subsection. For it is only when there are universal duties of justice borne by all others that a human right can be held to exist, as it is only then that a human right, which must be universal, can "be claimed by each from all."116 (By contrast, a special right exists when it is matched by special duties that fall on certain specified others.) The catalogue of human rights we are able to recognize may be less extensive as a consequence, but the rights recognized are stronger and therefore more credible.

\section{§ 2.2.2 - The Perspective of Rights and the Perspective of Duties}

At the outset of the previous subsection, it was briefly stated that I wish to take duties as a starting point, rather than rights. It must be clarified that this statement does not imply the belief that duties are somehow prior to rights, ontologically speaking as it were, or that we ought to grant duties greater normative importance. Taking the perspective of duties (as I shall refer to it, in contrast to the perspective of rights) is, instead, solely a methodological move. ${ }^{117}$ It will, firstly, allow us to identify rights more accurately, and, secondly, to gain a richer understanding of morality as a whole. Regarding the first point, we have already seen that adopting the perspective of rights can lead to the neglect of the correlative duties and, finally, to unclaimable human rights (when the correlative duties turn out to be either indeterminate or not allocated to concrete duty-bearers (or both) and thus imperfect). When, instead, we start from duties we are able to

116. O'Neill. Towards Justice and Virtue. 148. The implications of this understanding of human rights will be explored in Chapter 4.

117. The question whether duties are prior to rights or rather rights to duties need not concern us here. Our intention is more modest: to show that a renewed emphasis on duties can help us better determine (the content of) rights and to gain a richer view of morality as a whole (specifically of the scope of our duties). There are those, however, who do argue for the primacy of duties, as Simon Hope does in this passage: "The justification for any human right must, in the first instance, be a justification of the duties that right places on others, just as the justification for any action-guiding moral principle or demand must be" (Hope. Subsistence Needs, Human Rights, and Imperfect Duties. 90; cf. O'Neill. Acting on Principle. 21) Still, without committing to the claim that duties are the ground of rights, we may say that the opposite position, arguing that rights are the ground of duties, is clearly incorrect, for even the proponents of this position admit that there are such things as imperfect duties, that is, they accept the existence of duties without any corresponding rights. Given that these duties have no corresponding rights, these authors must grant the possibility of duties that do not have rights as the ground of their existence. 
formulate a clear criterion for genuine (human) rights: only where there is a possible duty of justice, can there also be a (human) right. By taking duties of justice to be indicative of (human) rights in this manner - that is, by using the presence (or absence) of duties of justice to distinguish genuine from merely purported (human) rights -, we are essentially making the claimability of rights (that is, the ability to claim the performance of their correlative duties) the precondition for their existence. After all, what sets duties of justice apart is the fact that their performance is owed to another, who may claim this performance from specific duty-bearers as her due. As perfect duties, the performance of duties of justice may be claimed, whereas the performance of imperfect duties cannot be claimed given their indeterminateness (if one does not know who must do what for whom, how can anyone claim anything from anyone else?).

It would thus seem that we have aligned ourselves with the will theory of human rights, for it maintains that the ability to exercise some measure of control over the performance of the correlative duty - that is, the ability to either claim or waive the right to such performance - is essential to having a right, and that where such control does not exist, there is no right. Indeed, one could argue that, though a theory of rights, the will theory focuses especially on the correlative duties when identifying rights. For example, Hart maintains that for a right to exist, the right-holder "should have at least some measure of the control . . . over the correlative obligation." 118 Such an obligation (or duty) can only be a duty of justice, as the performance of duties of virtue cannot be claimed by others, but relies on free self-constraint. In this sense, the will theory, too, makes the existence of (human) rights dependent on whether there are correlative duties of justice. ${ }^{119}$ Still, the present dissertation does not wish to decide the discussion between the will theory and the interest theory once and for all. Instead, it merely wishes to point out the merits of a renewed focus on duties, particularly within a human rights discourse. The first advantage of the perspective of duties, is that it can help preserve the force of human rights, by more accurately identifying human rights and thus rendering unclaimable "rights" impossible and preventing human rights inflation. Some of the practical consequences of this approach will be made apparent in Chapter 4, which will discuss the individual duties arising from global subsistence needs. 
The second reason for adopting the perspective of duties is, as said, to gain a richer understanding of morality. Onora O’Neill has made a convincing argument that by adopting the perspective of rights instead we inevitably remain blind to certain duties. ${ }^{120}$ Rights-based theories of morality tend to recognize solely duties of justice, to the detriment of other duties, as only duties of justice correlate with rights. Other duties that do not have corresponding rights - such as the imperfect duties whose corresponding rights become known only after a process of institutionalization (as is the case with many socio-economic (human) rights) and the imperfect duties that lack corresponding rights entirely often remain hidden to a rights-based morality. According to such a rights-based theory, so long as one has performed one's duties of justice - that is, so long as one has not violated the rights of another - one is at liberty to do whatever one wishes. Robert Louden has termed this position the rights infatuationist position. ${ }^{121}$ These rights infatuationists, Louden holds, are "structurally unable to account for the role that certain virtues, ends, and duties play in moral experience because of their single-element approach to moral theory construction."122 Lacking other normative concepts, the perspective of rights can do nothing but treat everything that does not amount to a violation of rights as permissible and morally acceptable. So long as one does not wrong another, one acts rightly. We, instead, wish to be able to differentiate between permissible expressions of personal interests and preferences, imperfect duties, and supererogatory acts. From the perspective of rights this becomes far more difficult, however, because of its neglect of imperfect duties. Yet, without imperfect duties, "all of these [i.e. permissible expressions of personal interests, imperfect duties, and supererogatory acts] may seem no more than ways in which we have a right to act, since others' rights are no constraint." ${ }^{23}$ The perspective of rights thus results in a severe narrowing of the scope of morality.

This problem with the perspective of rights becomes more perspicuous when we consider the well-known "right to do wrong." In arguing for such a right, Jeremy Waldron explains that rights do not provide reasons for acting, at least not for those who bear them. A right has nothing to say about the moral value of this or that action; all it does, is protect decision making in a particular area, in which the agent is to be safe from interference: "to protect decision

120. O’Neill. Towards Justice and Virtue. Chapter 5.

121. Louden. Rights Infatuation.

122. Ibid. 99. The single element, of course, being rights.

123. O’Neill, O. (1990). Children's Rights and Children's Lives. In Constructions of Reason: Explorations of Kant's Practical Philosophy (pp. 187-205). Cambridge: Cambridge University Press. 192. 
making is not to provide a reason for the making of any particular decision."124 It follows that one has a right ${ }^{125}$ to participate in a demonstration in support of a political party with openly racist views; one has a right to donate nothing to charity though one has the means to do so; one has a right to deliberately provide false information to hapless strangers asking for directions; one has a right not to vote (or to participate otherwise in democratic institutions). Having a right in these cases does not imply any judgment concerning the moral worth (or lack thereof rather) of the actions protected by the right. Provided one does not violate the rights of others, one therefore has a right to do wrong. ${ }^{126}$

I would argue that Waldron is correct concerning the function of rights: rights protect decision-making in a particular sphere of action and have nothing to say about the moral worth of the actions performed. Having clarified in this fashion the meaning and function of rights, the problem with a theory of morality that focuses solely (or chiefly) on rights becomes plain to see: by not recognizing (or simply by ignoring) duties of virtue, a rights-based theory will have difficulty explaining why, for example, giving part of one's income to charity is morally better than giving nothing to charity, or why it is wrong to not participate at all in the democratic institutions of one's country. After all, from a rights-based perspective, as long as one does not violate the rights of others, one can do no wrong; all further behavior is optional and merely permissible. Thus, when one does go beyond one's duties of justice, this is no longer viewed as a duty of beneficence or as civic duty (in the examples mentioned), but instead as merely permitted philanthropy or as optional acts of supererogation. ${ }^{127}$

One can see why this position is the logical outcome of a moral theory taking rights as its starting position. As mentioned at the outset of this section, Kant

124. Waldron. A Right to Do Wrong. 35.

125. Though perhaps one ought to speak of Hohfeldian "privileges," rather than rights. According to Hohfeld, if A has a privilege to $\Phi$, then $\mathrm{A}$ is under no duty not to $\Phi$. Furthermore, if A has a privilege to $\Phi$, it follows that B has no right (or claim) that A refrain from $\Phi$-ing. In short, Hohfeldian privileges (at times also referred to as "liberties") thus show what the holder of the privilege has no duty not to do (Hohfeld, W. N. (1913). Some Fundamental Legal Conceptions as Applied in Judicial Reasoning. The Yale Law Journal, 23(1), 16-59. 32ff.). So, for instance, I am under no duty to provide strangers with accurate directions to the Central Station. Conversely, they possess no right (no claim) to receive correct information from me.

126. Alternatively, one could say that one has a right to do wrong, provided one does not wrong others (that is, violate their rights).

127. For some examples of authors who take rights to be the fundamental moral category and as a consequence hold all acts beyond duties of justice to be supererogatory, see, e.g.: Rawls, J. (1999). A Theory of Justice (Revised Ed.). Cambridge (Mass): Belknap Press of Harvard University Press. 167; Gewirth. Private Philanthropy and Positive Rights (in which Gewirth appears to believe that there is no conceptual space between acts of supererogation and rights-based duties); Feinberg. The Nature and Value of Rights. 157 (where Feinberg holds that helping others when one has a right not to help them amounts to an act of supererogation). 
connected one person's possession of a right with a debt on the part of another (or several others). Accordingly, such rights-corresponding duties, i.e. duties of justice, are referred to by Kant as officium debiti (duties of indebtedness). ${ }^{128}$ If, to stay in the metaphor, one pays the precise amount of the debt, one has done all one must do; the duty of justice is fulfilled. However, if one pays a larger amount than the original debt, one has paid too much; one has gone beyond duty and literally performed an act of super-erogation (from the Latin "super" (over) and "erogare" (to pay out)). In other words, if one goes beyond what is required as a duty of justice, one goes beyond what one was bound (by the right of another) to do. For rights-based theories, it follows naturally that actions beyond the scope of duties of justice are acts of supererogation. These are the only terms such theories can work with, whether this is explicitly acknowledged or not. There appears to lie nothing in between duties of justice and acts of supererogation. Again, this makes sense once one realizes that for rights-based theories the only source of duties is rights. Any actions above and beyond such rights-corresponding duties are therefore supererogatory and thus wholly optional.

In sum, we have found that there are two main downsides to adopting the perspective of rights. Firstly, lack of attention for duties could lead to the recognition of unclaimable rights as genuine human rights, resulting in claimants clutching at straws. Instead, by taking duties as our point of departure, we are able to formulate a strict criterion for (human) rights, namely that only where there is a possible duty of justice, can there also be a genuine (human) right. By taking the perspective of duties, we can thus more accurately identify human rights, render unclaimable human rights impossible and prevent human rights inflation.

Secondly, the perspective of rights tends to only recognize those duties that correlate with rights, thus remaining blind to duties of virtue. This, in turn, leads to the consideration of all behavior which does not amount to a violation of rights as permissible, as no duties are recognized beyond duties of justice. As a consequence, all behavior going beyond one's duties of justice is considered supererogatory. This second disadvantage of adopting the perspective of rights has been summarized by O'Neill, playing on the title of Dworkin's famous book, as the failure "to take obligations seriously." 129

In conclusion, the adoption of the perspective of duties entails neither any judgment concerning the question whether duties are ontologically prior to (i.e. 
the basis of) rights ${ }^{130}$ or the other way around, nor does it imply any derogation of the worth of rights. Instead, our only reason for adopting the perspective of duties is methodological. It allows us to identify human rights and their correlative duties in a more precise fashion and it grants us a richer view of morality, one that is not limited to matters of justice (rights and duties of justice) but that extends into the realm of virtue as well.

\section{§ 2.3 - Conclusion: An Overview}

This chapter set out to clarify the central concepts and themes of the remainder of the dissertation. In $\$ 2.1$ we clarified the important distinction between perfect and imperfect duties as well as the distinction between duties of justice and duties of virtue. We, furthermore, took issue with the disparaging treatment of imperfect duties and duties of virtue in contemporary debates on duties. Accordingly, we first provided a negative argument illustrating how from the latitude and lack of corresponding rights it does not follow that these duties are any less important or binding. Next, a positive argument for the importance of duties of virtue was presented (in \$2.1.3), which set out two ways in which duties of virtue in fact serve as a complement to the sphere of justice.

Section 2.2, subsequently, expounded this dissertation's understanding of (human) rights as moral titles to limit the freedom of another by claiming the performance of a duty from him or her. It follows that if one is unable to claim such performance, then one does not possess the right in question. In other words, if there are no corresponding duties of justice borne by all or specific others, then there is no (universal or special) right to speak of. I have termed this approach, which moves from duties of justice to rights, the "perspective of duties," opposing it to the by far more common "perspective of rights," which instead moves from rights to duties. The advantages of the perspective of duties, we found, are twofold: firstly, by taking duties of justice to be indicative of rights we avoid the problems of unclaimable rights and rights inflation. Secondly, by starting from duties we can account not only for duties of justice, but also for duties of virtue. The latter escape one's view when one looks at morality from the perspective of rights instead, as it can only recognize rights-based duties, i.e. duties of justice. Duties of virtue are, consequently, reduced to mere optional excellences. 
As these various concepts have an important role to play in the remainder of this dissertation, it seems prudent to provide a handy overview, in which our various duties and possible corresponding rights can be organized:131

\begin{tabular}{|c|c|}
\hline Universal Duties of Justice ${ }^{132}$ & Special Duties of Justice ${ }^{133}$ \\
\hline - Owed by all & Held by specified duty-bearers \\
\hline - Claimable by all & Claimable by specified right-holders \\
\hline $\begin{array}{l}\text { Corresponding human rights (rights in rem) } \\
\text { for all }\end{array}$ & $\begin{array}{l}\text { - Corresponding special rights (rights in } \\
\text { personam) for a specified few }\end{array}$ \\
\hline
\end{tabular}

\begin{tabular}{|ll|l|}
\hline Universal Duties of Virtue ${ }^{134}$ & \multicolumn{2}{l|}{ Special Duties of Virtue ${ }^{135}$} \\
\hline$\cdot \quad$ Held by all & $\cdot \quad$ Held by specifiable others \\
\hline$\cdot \quad$ Claimable by none & $\cdot \quad$ Claimable by none \\
\hline$\cdot \quad$ No corresponding rights & $\cdot \quad$ No corresponding rights \\
\hline
\end{tabular}

\section{This table indicates that duties of justice require action from either all others (in} the case of human rights duties) or from a specific set of people (in the case of special duties of justice). These duties have correlative rights that are assigned to either all others or to particular individuals. Performance of these duties can be claimed or waived and is, in principle, enforceable.

We also see that duties of virtue do not give rise to rights. The performance of these duties can therefore neither be claimed nor waived and thus cannot be

131. Here I have drawn considerably on O'Neill's work on perfect and imperfect duties. See, e.g., O'Neill. Towards Justice and Virtue. Chapter 5; O'Neill. Children's Rights and Children's Lives.

132. Duties such as the duty to refrain from torturing others, the duty to respect the freedom of others to practice their religion, and the duty not to discriminate others are some examples of universal duties of justice.

133. Special rights and duties are positive rights and duties resulting from either the specific political context in which agents move (for example, the right to welfare and the duty to contribute to the welfare system through taxes) or from contracts, promises and other commitments freely undertaken by agents (for example, if I promise to pay back the money you lent me within the week, I have a duty to pay you back within that timeframe and you have a right to be paid back in a timely fashion).

134. E.g., the duty of beneficence. We all have a duty to aid those in need to the best of our ability, but whom we help and how we help them is left to our discretion. It follows that such a duty is unclaimable. Those in need do thus not have a right to our help, though we are under a duty to do all we can to help them.

135. E.g., certain duties of care arising from special relationships. While parents, for example, have a special duty of justice to take care of their children, they also have duties of virtue to provide them with specific forms of care: for example, to support them in their endeavors, to go to their soccer matches on Saturday, and so forth. Children cannot claim a right to such specific forms of treatment from their parents, but it is what makes good parents. 
enforced. The reason is that they are neither assigned to all nor to specified but rather to indeterminate others. Furthermore, their content is often not sufficiently defined. This can change, however, through the process of institutionalization, which can link right-holders to duty-bearers and specify the content of the duties in question.

A final observation one can make from this overview is that the rights-perspective leaves us with a truly impoverished moral landscape, as it can only recognize duties derived from rights, thus remaining blind to half our duties. 



\section{CHAPTER 3 - TWO CONTENTIOUS DUTIES}

The fulfilment of duty by each individual is a prerequisite to the rights of all [...] While rights exalt individual liberty, duties express the dignity of that liberty. ${ }^{1}$

In Chapter 1 we found that the two most contentious and unclear duties to be found in both human rights documents and human duties declarations are our duties of aid to the global poor and duties to the community. As a first step in clarifying these duties, this chapter will ascertain to what extent these duties have been explicated within the same, "juridical" discourse (involving both human rights documents and human duties declarations) in which they have been promulgated. Accordingly, $\$ 3.1$ will consider the treatment of our international duties of aid. The conclusion will be that neither the human rights documents themselves nor the General Comments of the Committee on Economic, Social and Cultural Rights (CESCR) nor the work of human rights scholars nor the various human duties declarations have succeeded in clarifying the duties of individuals towards the global poor. It will thus prove necessary to undertake a philosophical analysis of these duties in Chapter 4.

Subsequently, in $\$ 3.2$ I will explore the duties to the community that disquieted so many human rights scholars. This will be done by means of a study of Article 29 of the Universal Declaration. This section will be further divided into three subsections. First, §3.2.1 will provide an overview of the drafting history of this article. We will find that the article on duties to the community was considered by the drafters to be a crucial and integral part of the Declaration from the start. Subsection 3.2.2 will, secondly, examine what role the drafters intended Article 29 to have: What was the importance of an article expounding duties to the community in a declaration of human rights? It will become apparent that, far from posing a threat to human rights, such duties to the community in fact fulfill an important function: they provide us with a more balanced view of the relation between rights and duties as well as between the individual rights-bearer and the community of which she is a part. Finally, §3.2.3 will first answer the question which duties are actually intended when we speak of duties to the community. It will then move on to determine the status of these duties 
(are they duties of justice or duties of virtue?) as well as clarify what community it is to which we owe these duties.

\section{§ 3.1 - International Individual Duties of Aid}

The importance of examining individual duties relative to subsistence needs should require no argument; the numbers speak for themselves. If we exclude China, where the boisterous economic growth of roughly the last two decades has lifted hundreds of millions above the poverty line (set at $\$ 1.25$ a day ${ }^{2}$ ), there were in fact slightly more people suffering from poverty in 2008 (1.11 billion) than in 1981 (1.10 billion), though as a percentage of the global population there has actually been a decrease (from $40.5 \%$ in 1981 to $25.2 \%$ in 2008, not including China). ${ }^{3}$ The numbers are even worse if we employ a measure of $\$ 2$ a day: excluding China, the 1.6 billion people below the poverty line in 1981 had increased to 2.08 billion people in 2008 (the percentage dropped from $59.3 \%$ to $47.0 \%){ }^{4}$ The numbers and percentages, furthermore, differ vastly per region. Whereas the percentage of people getting by on less than $\$ 1.25$ a day in the 'East Asia and Pacific' region dropped from $77.2 \%$ in 1981 to $14.3 \%$ in 2008, the percentage in sub-Saharan Africa was more or less the same in 2008 (47.5\%) as it was in 1981 (51.5\%), while in this latter region the absolute numbers rose from 204.9 million people in 1981 to 386.0 million people in $2008 .^{5}$

Though the urgency of the problem is clear, this has not led, as I will show, in any progress in clarifying the duties of individuals arising from global subsistence needs. As will become apparent in what follows, neither human rights document nor the General Comments of the CESCR have addressed such duties. Human duties declarations do place individual duties towards the global poor on our shoulders, yet thus far they excel in vagueness. Therefore, I will conclude

2. Critics have argued that income data is too narrow a measure to assess poverty. The Human Development Reports of the United Nations Development Programme (UNDP), for example, have used Amartya Sen's notion of 'capabilities' to assess the quality of life and human welfare worldwide: "Freedoms and capabilities are a more expansive notion than basic needs" (UNDP. (2011). Human Development Report 2011. Sustainability and Equity: A Better Future for All. Retrieved from http://www.undp.org/content/ dam/undp/library/corporate/HDR/2011\%20Global\%20HDR/English/HDR_2011_EN_Complete. pdf. 1). Nonetheless, the use of income data will suffice here to provide an idea of the enormous scale of the problem of poverty worldwide.

3. Chen, S., \& Ravallion, M. (2013). More Relatively-Poor People in a Less Absolutely-Poor World. Review of Income and Wealth, 59(1), 1-28. 14.

4. Ibid. 15.

5. Ibid. 14. 
that further research is required, which will be undertaken, from a philosophical point of view, in Chapter 4.

The Universal Declaration of Human Rights speaks of a human right "to a standard of living adequate for the health and well-being of himself and of his family, including food, clothing, housing and medical care and necessary social services" (Article 25(1) UDHR). Similarly, the ICESCR recognizes everyone's right to "an adequate standard of living for himself and his family, including adequate food, clothing and housing, and to the continuous improvement of living conditions" (Article 11(1) ICESCR). These articles aim to show that the destitution of which I have spoken in the introduction of this section represents not simply a tragic state of affairs, but rather a violation of human rights. Consequently, remedying or at least alleviating such dire need is considered not a question of charity or beneficence, but rather a matter of justice. Making an adequate standard of living a right means that the impoverished individuals of this earth need no longer beg for aid, but may claim it. The drafters of these human rights documents thus wished to declare that those providing the aid are not performing an act of charity or supererogation, but are instead merely giving the right-holders what is owed to them. Indeed, this is precisely what having a right means: the power to limit the freedom of the duty-bearer to act in accordance with one's right.

However, despite the clear importance of an adequate standard of living for all, questions remain whether it ought to be (and even can be) the subject of a human right. There are those who disagree that this human right constitutes a right at all; that is, they even disagree that it should be a right within a state, that is, a right one has as a citizen. This is a particularly minimalist form of traditional liberalism (libertarianism) that will not further concern us here. Others, and this point of critique will be elaborately presented in the following chapter, maintain that it is not a human right. This position holds that, in contrast to civil and political rights, socio-economic rights can only be special rights - i.e. rights one has as a citizen with respect to one's government or some other institutional order that allocates duties -, but not universal rights one possesses simply as a human being that give rise to claims against all. By contrast, my right to be free from torture, for example, is truly universal: all have this right against all others. ${ }^{6}$

Within human rights circles, the most often heard rebuttal of this criticism, points out the indivisibility and interdependence of human rights. What is 
meant by this can be most clearly illustrated by considering the right to life. This right has traditionally been understood as a purely negative right entailing solely negative duties of forbearance. However, it has become ever more common to regard this right no longer merely as a negative right. For example, in the famous Case of the 'Street Children' v. Guatemala the Inter-American Court of Human Rights ruled that "the fundamental right to life includes, not only the right of every human being not to be deprived of his life arbitrarily, but also the right that he will not be prevented from having access to the conditions that guarantee a dignified existence." W With this statement the Inter-American Court intends to show that the right to life does not only involve a negative duty of respect for life (i.e. a duty to refrain from killing), but also a positive duty of creating conditions in which all are guaranteed the protection of their right to life, by setting up, e.g., a police force and an independent judicial branch. Traditional civil rights thus also require positive duties, when it comes to their enforcement. Indeed, many have argued that the interdependence between the right to life and subsistence rights such as the rights to health, food, water and education is apparent. ${ }^{8}$ The Inter-American Court affirms this interdependence and indivisibility of all rights and therefore concludes that the right to life belongs "at the same time, to the domain of civil and political rights, as well as economic, social and cultural rights, thus illustrating the interrelation and indivisibility of all human rights."

In the common preamble of the ICCPR and the ICESCR this interrelation and indivisibility is further clarified by pointing out the goal of human rights: the realization of "the ideal of the free human being." The preamble stresses that this ideal of free human agency "can only be achieved if conditions are created whereby everyone may enjoy his economic, social and cultural rights as well as his civil and political rights." This indivisibility of all human rights has led to the (within human rights circles) common conclusion that there is no great disparity between first and second generation human rights, but that rather all human rights give rise to the same set of three duties, namely duties to respect, protect and fulfill. ${ }^{10}$

7. Inter-American Court of Human Rights. Villagrán Morales et al. v. Guatemala (the 'Street Children' Case). Judgment of Nov. 19, 1999 (Merits). Inter-Am. Ct. H.R. (Ser. C) No. 63. Para. 144.

8. See, e.g., Van Boven, T. (2010). Categories of Rights. In D. Moeckli, S. Shah, \& S. Sivakumaran (Eds.), International Human Rights Law (pp. 173-188). Oxford: Oxford University Press. 179.

9. Inter-American Court of Human Rights, Villagrán Morales et al. v. Guatemala. Joint concurring opinion. Para. 4.

10. Cf. Maastricht Guidelines on Violations of Economic, Social and Cultural Rights. Reprinted in (1998) Human Rights Quarterly, 20(3), 691-704. Guideline 6: "Like civil and political rights, economic, social and cultural rights impose three different types of obligations on States: the obligations to respect, protect and fulfill.” This tripartite classification of duties, however, comes from the field of philosophy, specifically from the work of Henry Shue: Shue. Basic Rights. 52. 
Specifically with regard to poverty, the CESCR opts for an understanding of poverty beyond a simple lack of enough income for food and other essentials. Instead, it advocates a view of poverty based loosely on Amartya Sen's capabilities approach. The Committee's definition of poverty "recognizes poverty's broader features, such as hunger, poor education, discrimination, vulnerability and social exclusion." ${ }^{11}$ Poverty, in essence, thus consists in violations of both socio-economic and civil-political rights. The Committee "endorses this multi-dimensional understanding of poverty, which reflects the indivisible and interdependent nature of all human rights." ${ }^{12}$

To what duties does this understanding of poverty give rise? Let us take the right to food, which is one of the rights that make up the right to an adequate standard of living, as an example. It should be clear by now that the duties of states with regard to this right are not to be limited to non-interference. Indeed, the Maastricht Guidelines on Violations of Economic, Social and Cultural Rights have put forward the position, following Henry Shue's tripartite division of duties, that states ought to do more than refrain from taking measures which result in further violations of the right to food (duty to respect). They must also protect their citizens' right to food by preventing violations by third parties (duty to protect). Finally, the CESCR has stated that the duty to fulfill consists of two further duties: the duty to facilitate and the duty to provide. The former entails a duty of the state to "pro-actively engage in activities intended to strengthen people's access to and utilization of resources and means to ensure their livelihood, including food security."13 The latter duty comes into play when an individual or group lacks the means to enjoy the right to food. In this case, the state has a duty to provide the necessities for fulfilling the right. This last duty also applies in cases of natural disasters or other acute emergencies.

Adequately performing the abovementioned duties will not be possible in the same degree for the various states. After all, there are states, which, due to a lack of funds and infrastructure, are unable to provide the needy among their citizens with (access to) food. There are also states that are gripped in a (civil) war. Some states lack the military muscle to protect their citizens' access to food from attacks by third parties, such as rebel groups. In short, the degree to which states will be able to perform their duties will vary greatly. But surely we would not wish to say that the willing government of a poor, war-torn state is violat- 
ing its citizens' human rights when it fails to provide those in need with aid? Indeed, the drafters of both the UDHR and the ICESCR would have agreed. Thus, whereas the ICCPR declares that each state must take the necessary steps "to adopt such laws or other measures as may be necessary to give effect to the rights recognized in the present Covenant" (Article 2(1) ICCPR), the same article in the ICESCR is more modest; it asserts that each state must "take steps, individually and through international assistance and co-operation [...], to the maximum of its available resources, with a view to achieving progressively the full realization of the rights recognized in the present Covenant" (Article 2(1) ICESCR, emphasis added). Similarly, Article 22 of the UDHR reads: "Everyone, as a member of society, has the right to social security and is entitled to realization, through national effort and international co-operation and in accordance with the organization and resources of each State, of the economic, social and cultural rights indispensable for his dignity and the free development of his personality" (emphasis added). International human rights law has thus taken into account the varying degrees of wealth, infrastructure, and conditions of war or peace present in different countries.

Nevertheless, states do have certain minimum core obligations "to ensure the satisfaction of, at the very least, minimum essential levels of each of the rights" 14 of the ICESCR. If a considerable number of individuals in a particular state is deprived of enough food, adequate shelter or the most elementary forms of education, that state will therefore be found failing in its duties, and thus in violation of the Covenant. If such a state claims to be nonetheless doing the most it can with the resources available to it, the onus of proof will lie with that state to show there are indeed extenuating circumstances of the sort discussed above (poverty, war, natural disaster, and so forth).

Moving towards the fundamental aim of this section - i.e. the clarifying of the duties of individuals towards the global poor from within the human rights discourse - we may inquire what the duties of the developed world are towards a state that is unable to fulfill even its minimum core obligations. We can find appeals for international cooperation with respect to the realization of subsistence rights expressed in rather general terms in the UDHR (Article 22), the ICESCR (Articles 2(1) and 11) and the UN Charter (Articles 1 and 56). In General Comment No. 12, the CESCR elaborates on the content of these duties of international cooperation with regard to the right to food. Essentially, it 
amounts to the tripartite division of duties discussed above. ${ }^{15}$ States parties must not conduct any activities within their own jurisdiction or abroad which could endanger other states' abilities to ensure the right to food for their citizens. This duty of respect further includes the duty to refrain from employing food as an instrument of political or economic pressure. ${ }^{16}$ The CESCR furthermore explains the duty to fulfill (provide) as entailing duties to provide disaster relief as well as humanitarian assistance in the event of a calamity. This assistance, moreover, includes assistance to refugees and internally displaced persons. ${ }^{17}$ The CESCR does not further elucidate the content of the remaining duties (to protect, and to fulfill (facilitate)), but it does reiterate that each state should provide assistance in accordance with its ability and resources. Controversially, the CESCR argues that the drafters of the Covenant intended the phrase "to the maximum of its available resources," mentioned in Article 2(1), to "refer to both the resources existing within a State and those available from the international community." 18 It thus seems that, according to the CESCR, the wealthy countries ought to consider a part of their resources (how much exactly is not spelled out) "as part of those which should be available for the realisation of socio-economic rights in developing countries."19

According to some scholars, however, the duties of international cooperation extend beyond the "mere" provision of aid. They point to Article 28 UDHR in order to argue, in addition, for duties to contribute to the achievement of a just global order:20 "Everyone is entitled to a social and international order in which the rights and freedoms set forth in this Declaration can be fully realized." A just social and international order is thus considered to be the precondition for the possibility of the realization of all human rights. Given that no (or very few) legal systems, and political economic orders today can truly ensure the complete realization of human rights, this article contains a potentially radical claim for change. As Thomas Pogge has convincingly argued, the manner in which the international order is structured has a negative effect on world poverty levels

15. CESCR. General Comment No. 12. Para. 36.

16. Bojic Bultrini, D. (2009). Guide on Legislating for the Right to Food. Rome: Food and Agriculture Organization of the United Nations. 26.

17. CESCR. General Comment No. 12. Para. 38.

18. CESCR. General Comment No. 3. Para. 13.

19. Curtis, J., \& Darcy, S. (2012). The Right to a Social and International Order for the Realisation of Human Rights: Article 28 of the Universal Declaration and International Cooperation. In D. Keane \& Y. McDermott (Eds.), The Challenge of Human Rights: Past, Present and Future (pp. 9-35). Cheltenham: Edward Elgar Publishing. 26.

20. The best known of these scholars would, of course, be Thomas Pogge: Pogge, T. (1992). O’Neill on Rights and Duties. Philosophische Studien, 43, 233-247. 246; Pogge, T. (2008). World Poverty and Human Rights: Cosmopolitan Responsibilities and Reforms (2nd ed.). Cambridge: Polity Press. 70-1. 
and human rights fulfillment. Heavy agricultural subsidies in the EU and the US, the international borrowing and resource privileges, ${ }^{21}$ the underrepresentation of developing nations in international financial institutions (e.g., the IMF and the WTO), the TRIPS Agreement, ${ }^{22}$ the imposition of high import tariffs by the developed nations - all these measures work together in creating an international order very far removed from the order discussed in Article 28. As a consequence, state duties of international cooperation are not simply limited to duties of direct aid, but rather also contain duties to reform the existing international order in a manner that can ensure the enjoyment of rights for all, ideally rendering the duties of aid less and less important.

We have thus found that the duties of international cooperation of states to respect, protect and fulfill subsistence rights also involve duties to (together with other nations) reform the international order (particularly the rules of trade and finance), which foreseeably leads to violations of subsistence rights. Perhaps it is because our current global order systematically brings about great discrepancies between wealth and power among nations, that the CESCR maintains that those who have benefited most from that order (i.e. the wealthy nations) ought to consider part of their resources as belonging to those within the international community who have the greatest need for such resources. Conceivably, though no such argument is provided, the amount a state would be obligated to contribute would depend on the extent to which it has profited from the current unjust global order, as well as that state's power and influence over the direction of trade and finance.

We may conclude that with regard to state duties to prevent and alleviate poverty, human rights law has taken great steps forward in defining their content and scope. The duties of non-state actors are discussed less and in a vaguer fashion, but human rights law has started to rectify this oversight. ${ }^{23}$ However, when it comes to the duties of individuals, a crushing silence reigns. We have seen that both the UDHR and the ICESCR recognize the right to an adequate standard of living. Yet, nowhere in these documents, the CESCR's General Comments,

21. Pogge, T. (2002). Human Rights and Human Responsibilities. In P. De Greiff \& C.P. Cronin (Eds.), Global Justice and Transnational Politics (pp. 151-195). Cambridge, MA: The MIT Press. 171-3.

22. The agreement on Trade-Related Aspects of Intellectual Property Rights (TRIPS) is held to severely limit access to advanced medicines in poorer countries. Cf. Pogge. World Poverty and Human Rights. Chapter 9.

23. CESCR. General Comment No. 12. Paras. 40-1. Paragraph 40 discusses the role of NGO's, whereas paragraph 41 contains a number of recommendations for international financial institutions with regard to securing the right to food; cf. CESCR. General Comment No. 14: The Right to the Highest Attainable Standard of Health (Art. 12). E/C.12/2000/4 (11 August 2000). Paras. 63-5. Also see footnotes 31, 32 and 33 from Chapter 1. 
or the work of human rights scholars, are we provided an adequate treatment of the duties of individuals that spring from this right. Individual duties are offered perfunctory mention at best. Thus, the CESCR helpfully explains that all members of society (including individuals) "have responsibilities in the realization of the right to food," ${ }^{24}$ but leaves the question of the exact content and status of these "responsibilities" ${ }^{25}$ wide open. Regarding this passage from the CESCR's General Comment No. 12, leading human rights scholars Saul, Kinley and Mowbray confirm the existence of ancillary duty-bearers when states are unable to fulfill their minimum core obligations. Yet, in the same breath, they state that "while it may seem reasonable to suggest that the private sector (and especially the private business sector) should have responsibilities to respect the right to adequate food, this appears to fall short by failing to follow through with details of how and why." 26

In short, if one desires to know which duties one has as an individual, as a consequence of Article 25 UDHR (or Article 11 ICESCR), one should not expect to find any answers in human rights documents, General Comments of the CESCR or the work of scholars of human rights law. Are we to conclude that therefore individuals have no real duties regarding the right to an adequate standard of living?

As discussed in Chapter 1, it was discontent with the supposed lack of attention for individual duties within human rights documents that led to the birth of several human duties declarations. Surely, these declarations will have more to say on the matter of our duties to the global poor. Let us first consider the treatment of these duties by the UDHRe. It is clear that this declaration wishes to address duties to the poor, as becomes apparent from, for instance, Article 9: "All people, given the necessary tools, have a responsibility to make serious efforts to overcome poverty, malnutrition, ignorance, and inequality." Yet, what form such efforts should take, and whether we owe them to all human beings or only to our

24. CESCR. General Comment No. 12. Para. 20.

25. When individual duties are mentioned, the CESCR suddenly uses the word "responsibility," whereas it always uses the word "obligation" to refer to the duties of states. Wherein the difference between "responsibility" and "obligation" consists, however, is left unsaid, as is the reason for attributing the one term to states and the other to individuals.

26. Saul, B., Kinley, D., \& Mowbray, J. (2014). The International Covenant on Economic, Social and Cultural Rights: Commentary, Cases, and Materials. Oxford: Oxford University Press. 872. The authors' parenthetical remark in this passage suggests that when it comes to ancillary duty-bearers they are not so much interested in the duties of individuals, but rather with those of (transnational) corporations. Indeed, following the quoted passage, this suspicion is confirmed, as the authors go on to only discuss the duties of corporations. 
compatriots remains unclear. Article 10 continues along the same path: "Everyone should lend support to the needy, the disadvantaged, the disabled and to the victims of discrimination." Again, the kind and amount of support is not explicated. Similarly, Article 20 DHSR states that one has a duty to use one's wealth "for the benefit of the progress of Humanity as a whole." The exact meaning of "the progress of Humanity," however, as well as how one is to contribute to it, is left nebulous.

Furthermore, in Article 11 UDHRe, the drafters took on the contentious issue of a just economic and social order, perhaps intending to provide the duty correlative to the right expressed in Article 28 UDHR ("Everyone is entitled to a social and international order in which the rights and freedoms set forth in this Declaration can be fully realized"). What form such an order should take and what the duties of individuals are in light of achieving that just order, are questions that are, once more, left unanswered..$^{27}$

Interestingly, as Pogge points out, ${ }^{28}$ the Golden Rule, mentioned in Article 4 UDHRe, is provided only in its negative version: "What you do not wish to be done to yourself, do not do to others." This would seem to imply that, as long as I am not actively harming others, I have fulfilled all my duties, which apparently include solely negative duties of forbearance. Such a position, however, is in contrast with the "spirit of solidarity" espoused in that same article, which would appear to call for the positive version of the Golden Rule instead: do unto others as you would have them do unto you. Yet, this positive variety is not mentioned, though it would have in fact been more appropriate.

Many human duties declarations are, furthermore, confused regarding the status of their prescribed duties: are they possibly enforceable duties of justice or rather duties of virtue, the fulfillment of which lies at the discretion of the agent? The drafters of many human duties declarations claim they have included solely

27. The DHSR also contains an article prescribing a duty correlative to the right expressed in Article 28 UDHR: "Every person has the duty to contribute actively to the achievement, both at the international level and in his or her own community/society, of an international and social order under which all the rights and freedoms recognized in the Universal Declaration of Human Rights and in other pertinent international instruments are made fully effective" (Article 11). Unfortunately, this article does not provide us with any information concerning the shape this duty ought to take in practice. For instance, what does "contribute actively" entail? A similar criticism can be leveled against Article 18(3) of the Declaration on the Right and Responsibility of Individuals, Groups and Organs of Society to Promote and Protect Universally Recognized Human Rights and Fundamental Freedoms (adopted by the General Assembly of the United Nations on 9 December 1998): "Individuals, groups, institutions and non-governmental organizations also have an important role and a responsibility in contributing, as appropriate, to the promotion of the right of everyone to a social and international order in which the rights and freedoms set forth in the Universal Declaration of Human Rights and other human rights instruments can be fully realized." What does that "role and responsibility" require of us? How much is "appropriate?"

28. Pogge. Human Rights and Human Responsibilities. 156-7. 
duties of a moral nature, yet they also contain unambiguous legal duties (e.g. the duty to respect life and to refrain from killing or injuring another (Article 5 UDHRe)). It is therefore apparent that the drafters have not thought through the distinction between duties of justice and duties of virtue. As a consequence, it is not only the content of our individual duties regarding global subsistence needs that remains unclear, but also their status.

The most recent human duties declaration (the draft resolution on Fundamental Rights and Responsibilities (FRR) issued by the Council of Europe in 2011) does attempt to distinguish between legal and moral duties, but does not say much more than that the legal duties may not place too heavy a burden on the duty-bearer, without any further explanation. The distinction between duties of justice and duties of virtue therefore remains wanting in clarity. As a consequence, the status of our duties to the global poor continues to be open to dispute as well. This declaration, furthermore, provides some more details regarding the content of our duties to the poor. However, it understands the "responsibility to show solidarity towards other members of the community" (Article 12 FRR) as pertaining chiefly to one's fellow citizens, as becomes clear from its commentary. One can fulfill this responsibility, it explains, by paying taxes and contributing to a national system of social welfare. Thus, though the FRR does provide us with clear individual duties, it cannot provide us with any guidance concerning our individual duties towards the global poor.

We must conclude that human rights discourse (considered broadly here, thus including human duties declarations as well) has as yet failed to provide a clear description of the individual duties that correlate with the human right to an adequate standard of living. Whereas the duties of states have been made increasingly clear, and the duties of non-state actors have also begun to be elucidated, the duties individuals have in combating global poverty remain completely in the dark. It remains to be seen, in Chapter 4, whether philosophy will fare much better in explicating our duties to the global poor and in providing answers to questions such as the following: Why do we have duties to the poor in the first place? Is the right to an adequate standard of living a universal human right or rather a special right? Are our duties concerning global poverty duties of virtue or duties of justice, claimable by right-holders? All I hope to have shown here is that there is a gaping hole where the specification of the content, scope and status of individual duties regarding global poverty ought to be. The next chapter will provide an examination of the contemporary debate in political and legal philosophy concerning global justice for answers to such questions. 


\section{§ 3.2 - The Role and Significance of Duties to the Community within the Universal Declaration}

The second of the two most contentious and ambiguous duties encountered in Chapter 1 are the duties to the community. These duties are no doubt more contentious among human rights scholars than the duties to the global poor. The reason for this is that so-called vertical duties owed by the individual to the community are viewed, as became apparent in Chapter 1, as possible illegitimate and dangerous limits to our rights. It is therefore the main goal of this section to abate these fears and to demonstrate how such duties to the community instead perform an indispensable function. This will be done by means of a study of Article 29 UDHR, the first paragraph of which places duties to the community on us: "Everyone has duties to the community in which alone the free and full development of his personality is possible." I have chosen to discuss the Universal Declaration's formulation of duties to the community for two reasons. Firstly, the document carries considerable weight, as the foundational document of international human rights law. Secondly, the drafting history of this article contains discussions among drafters on questions that are central to our purposes here, namely the relation between rights and duties as well as between the individual bearer of rights and the larger community within which she finds herself.

This section will be structured as follows: first, \$3.2.1 will provide a study of the drafting history of Article 29 UDHR. Situated near the very end of the Universal Declaration, one might be tempted to conclude that Article 29 was hastily attached at the very last minute to a document that was essentially already complete. Even a cursory look at the drafting history, however, will rid us of the notion that Article 29 was a mere addendum, appended to the Declaration solely pro forma. On the basis of a study of the drafting history, I will reach the conclusion that the drafters viewed Article 29 as central to the Declaration as a whole.

Subsequently, §3.2.2 will move beyond a mere exposition of the drafting history to an interpretation of the meaning and function of Article 29(1) in the Universal Declaration as a whole. This subsection wishes to clarify the significance of the addition of duties to the community to a human rights declaration for our understanding of the nature of such rights as well as for our comprehension of the relation between the individual rights-bearer and the community at large. The point will be made that by insisting on duties to the community, the drafters wished to place our rights within a larger moral context and strike a balance between the rights we enjoy and the duties we owe. By bestowing such im- 
portance on duties to the community, the drafters furthermore intended to avoid the image of the lone rights-bearer completely detached from society and instead proposed a more balanced view: the rights-bearer is not only a distinct individual, but also undeniably a part of the community in which she finds herself. The drafters thus present us with an appealing intermediate position that avoids the trappings of both an extreme individualism and a rigorous collectivism.

This second subsection will end by considering the educational function of the Universal Declaration. A brief look at Article 26(2) will suffice to demonstrate that the drafters realized that the promulgation of rights and the imposition of duties would not suffice to render human rights secure. Rather, what is additionally needed can be best described as a change in people's disposition. Article 26(2) proposes that the educational system be used to realize this change. Essentially, the drafters hereby make the case that states ought to take an active role in utilizing the educational system in order to cultivate a certain kind of citizen: one that both insists on her rights and recognizes her duties; one that is both part of a particular community and also a distinct individual. In other words, the drafters argue for the instilment of civic virtue.

Lastly, §3.2.3 will clarify what duties are in fact intended by the phrase "duties to the community." Three separate categories of such duties will be distinguished. Subsequently, the status of each of these three categories of duties will be determined. Finally, having already established what actual duties are intended by the phrase "duties to the community," it will become possible to determine what precisely is meant by the term "community." To interpret this community as a political community of citizens and therefore the duties to the community as civic duties, seems the most convincing reading.

\section{§ 3.2.1 - Drafting History}

Already the very first preliminary draft of what was to become the Universal Declaration - the so-called Humphrey draft (named after John Peters Humphrey who prepared it) - contained an article on duties. Emphasizing the importance that was attached to such an article - Humphrey had, after all, prepared his draft after having conferred with the executive group of the Commission on Human Rights Drafting Committee, chaired by Eleanor Roosevelt -, it was placed at the very beginning of the draft. Its Article 1 differed quite substantially from the final version: "Every one owes a duty of loyalty to his State and to the (international society) United Nations. He must accept his just share of responsibility for 
the performance of such social duties and his share of such common sacrifices as may contribute to the common good." ${ }^{29}$ Yet, though the importance of an article expounding our duties was generally acknowledged, several delegates felt uneasy by defining those duties as duties to the state. Thus the Rapporteur of the Commission, Charles Malik of Lebanon, questioned the desirability of an unqualified "duty of loyalty to the State." Given the recent experiences of war waged by totalitarian states, we can understand why Malik argued that we do not owe a duty of loyalty to simply any state, but rather only to a just state. ${ }^{30}$

Due to sustained criticism of the mentioning of the state in the article listing our duties, René Cassin of France avoided any mention of the state in his draft declaration. In his revision of the Humphrey text, Cassin placed the article concerning our duties once again near the beginning of the document. Thus, Article 3 reads: "Man is essentially social and has fundamental duties to his fellow-men. The rights of each are therefore limited by the rights of others." ${ }^{31}$ His alternative formulation of this article can be viewed as a more elaborate version of the current Article 29(1) and can therefore help us to better understand this article: "As human beings cannot live and develop themselves without the help and support of society, each one owes to society fundamental duties which are: obedience to law, exercise of a useful activity, willing acceptance of obligations and sacrifices demanded for the common good." 32 The cause for our duties is made more explicit here than it is in the final version: it is because we are dependent on society for our life and development that we owe it certain duties. Whereas these duties, furthermore, are left unspecified in the final version of the UDHR, Cassin's draft gives us an idea of which duties could have been intended in Article 29(1).

Article 29(2) UDHR embodies the idea that neither rights nor freedom are absolute, but rather that both ought to be limited in order to secure "due recognition and respect for the rights and freedoms of others and of meeting the just requirements of morality, public order and the general welfare in a democratic society" (Article 29(2) UDHR). This view was widely shared by the various delegates. Thus, William Hodgson of Australia argued that none of the rights in the draft declaration are to be considered limitless. Rather, "[e]veryone of these rights has a corresponding duty," namely a "duty to respect the rights of others." 33 The British delegate Lord Charles Dukeston (trade unionist and Labour politi- 
cian) agreed with the Australian delegate, adding: "It is of no use in my opinion of seeking to define personal freedom entirely detached from the obligation of those individuals either to the State or to voluntary organizations." ${ }^{34}$ The sentiment was shared not only by Western countries, but also by the Latin-American delegates who less than a year later would adopt their own (and the world's first) international human rights declaration. Thus, with regard to the second article of Humphrey's draft ${ }^{35}$ (a precursor of the final Article 29(2)) Panama proposed: "In the exercise of his rights every one is limited by the rights of others and by the just requirements of the democratic state." ${ }^{36}$ We can see how this proposal starts to come close to the eventual formulation in Article 29(2) by specifying that one's rights are limited by the just requirements of not just any kind of state, but rather only of a democratic state.

Article 29(3) additionally mentions that the exercise of our rights and freedoms may not be "contrary to the purposes and principles of the United Nations." Recall that the very first article on duties, drawn up by Humphrey, contained a duty of loyalty not only to the state, but also to the United Nations. Without providing any explanation, however, Cassin removed any mention of a duty to the international community from his draft, which only reappeared at the time of the Third Committee. At this point, the article on duties had already been moved to the end of the draft declaration as Article 27 (about which I will have something to say in a moment), the second section of which read as follows: "In the exercise of his rights, everyone shall be subject only to such limitations as are necessary to secure due recognition and respect for the rights of others and the requirements of morality, public order and general welfare in a democratic society." 37 The French delegation suggested to add to this limitation clause, which is very close to the final version in Article 29(2), the following phrase: "and to serve the purposes and principles of the United Nations." 38 Nearly all those who addressed the matter of expanding the circle of our duties to the point that it encompasses not only our own national community but also the international community as a whole, ${ }^{39}$ spoke out in favor of the idea. The Belgian representa-

\footnotetext{
34. Ibid. 6.

35. UN Doc. E/CN.4/AC.1/3 (4 June 1947): "In the exercise of his rights every one is limited by the rights of others and the just requirements of the State and of the United Nations."

36. UN Doc. E/CN.4/AC.1/3/Add.1. (11 June 1947). 12.

37. UN Doc. A/C.3/304/Rev.1 (30 October 1948).

38. UN Doc. A/C.3/345 (17 November 1948).

39. The word "community" was chosen precisely because it does not exclusively refer to one particular community (as the word "state" does, for instance). Rather, it refers to communities both larger than the national community (regional communities or the international community at large) and smaller (e.g. the city you belong to, your neighborhood, and so forth).
} 
tive Fernand Dehousse found the idea expressed in the French addition of such importance that he argued it deserved a separate paragraph. This proposal could count on the assent of the majority, eventually leading to the adoption of Article 29(3). ${ }^{40}$ The point of this article was to emphasize the idea that the individual was not only a part of her own national community, but that she also belonged to the international community as a whole; she is to view the interests of this larger, global community as her interests. Adding this section to an article dealing with our duties and the limits of our rights is quite significant: it means that no citizen in any country can consider herself and her country's interests to be detached from the interests of others worldwide. It means that in exercising her freedom she is to take into account, as far as she can, the possible consequences of her actions not only for her fellow citizens, but also for agents worldwide.

Having briefly discussed the drafting history of all three sections of Article 29 UDHR, one question concerning the drafting process remains for us to answer: How did the article(s) listing our duties come to be moved from the beginning to the end of the Declaration? Did the drafters suddenly have a change of heart regarding the importance of our duties? In his study on the Universal Declaration Johannes Morsink explains how, strangely enough, the proposal to place the duties-article at the end of the document came from the representative of China, Peng-Chun Chang who was also vice-president of the UN Commission on Human Rights. He argued that an "article which dealt with the limitations on the exercise of the rights and freedoms proclaimed in the Declaration should not appear before those rights and freedoms themselves had been set forth." ${ }^{41}$ As the Chinese delegate, Chang was expected to provide a Confucian, communitarian input. All the more striking, then, that it was he who argued against a place of prominence for the article listing our duties to the community and the limitations on the exercise of our rights and freedoms. Perhaps he did not embrace such traditional Chinese views due to his Western education. Perhaps he was distraught due to the unrest back in China. Or perhaps he simply was not feeling well. ${ }^{42}$ Whatever the reason for this out-of-character proposal, however, its adoption should not lead us to conclude, Morsink warns, ${ }^{43}$ that the UDHR stands in the exact same tradition as the bills of rights that were drawn up at the end of the eighteenth century, with their strong emphasis on individualistic, negative liber-

40. Morsink. The Universal Declaration of Human Rights. 252.

41. UN Doc. E/CN.4/SR.77 (28 June 1948). 2.

42. Morsink explores various explanations for Chang's odd behavior: Morsink. The Universal Declaration. 245-6.

43. Ibid. 245. 
ty. In fact, there was quite some resistance to Chang's proposal. The British delegate Geoffrey Wilson, for example, was opposed to the proposal, as he wanted to avoid the impression that "the individual was granted unlimited rights." ${ }^{4}$ The delegate from the USSR Alexei Pavlov agreed with his British colleague, adding that the article listing our duties and the limits of our rights should be viewed as a general provision and, as such, ought to precede the "more specific clauses." 45 Eventually, Chang's proposal was adopted by the smallest possible majority: 8 in favor, 7 opposed and 1 abstention. ${ }^{46}$

This extremely narrow majority illustrates that many delegates placed great importance on what eventually became Article 29 and would have preferred to keep it at the beginning of the Declaration. Its final placement should therefore not lead us to infer that the drafters intended it as an afterthought of little importance. Rather, the article had been an integral part of the Declaration from the outset. The narrowly won vote to place the article at the end of the Declaration rather seems to form an exception to their habitual treatment of the article up until that point. Moreover, much can be said for the position that the drafters made a mistake by adopting Chang's proposal. As the delegate from the USSR pointed out, Article 29 clearly forms a general provision and should as such be placed at the outset of the document alongside Articles 1 and 2, which similarly contain fundamental principles that serve as interpretive tools for the remainder of the Declaration.

\section{$\S$ 3.2.2 - Interpretation}

If we are to understand the function of Article 29, we must first understand the structure of the Universal Declaration as a whole. It is not just a collection of separate rights gathered together in one document. Rather, the different parts of the Declaration are intimately linked to one another. Thus, René Cassin, the French delegate responsible for the revision of the Humphrey draft, compared the structure of the Declaration to the portico of a temple. ${ }^{47}$ Accordingly, the seven clauses from the document's Preamble form the seven steps leading up to the portico. The foundation of the whole structure is formed by four foundation 
stones. These are the four general principles that can be found in Articles 1 and 2, namely freedom, equality, dignity and brotherhood. Together, the steps and the foundation stones - that is, the Preamble, Proclamation and the first two articles - lay down a number of principles and purposes, which are to guide the reader in her interpretation of the articles that follow. As briefly discussed above, Cassin's draft had placed both an article stating our duties and an article defining the limits on the exercise of our rights and freedoms at the beginning of his draft declaration. ${ }^{48}$ What eventually became Articles 29(1) and 29(2) were initially therefore intended as such interpretive guides as well, just as Articles 1 and 2.

Cassin's fourfold division of the rights listed in the Declaration appears somewhat forced to me, so I will not discuss it here. ${ }^{49}$ A more likely (and more common) division is that between civil and political rights on the one hand (Articles 3 through 21) and economic, social and cultural rights on the other hand (Articles 22 through 27). In any case, the point is that in his metaphor of the portico the columns are formed by the several rights listed in Articles 3 through 27.

More importantly for our purposes, Cassin viewed the remaining three articles (Articles 28, 29 and 30) as the pediment of the portico, which completes the structure and holds it together. As Mary Ann Glendon points out, these articles tie the individual and the community to each other and place "the enumerated rights in the context of limits, duties, and the social and political order in which they are to be realized." 50 The image illustrates how our rights would remain somewhat unbound, as it were, without the direction provided by the final articles. As the columns of the portico would remain unstable without the pediment in place and would risk tilting or perhaps eventually even falling over, so too the adequate protection of rights would be at risk without the necessary concomitant duties and limits. The security of rights, in other words, depends on the regular performance of duties. The pediment completes the framework in which human rights can be realized. What this framework exactly entails, must now be explained. To that end, we must provide an interpretation of Articles 28, 29 and 30, whereby the main focus will lie on Article 29.

We may be brief about Article 30, as it contains a simple general abuse clause, similar to Article 17 ECHR, discussed in Chapter 1: "Nothing in this

48. UN Doc. E/CN.4/AC.1/W.2/Rev.2 (20 June 1947). Articles 3 and 4.

49. According to this fourfold division, the first column is formed by Articles 3 through 11, the second by Articles 12 through 17, the third by Articles 18 through 21, and the fourth by Articles 22 through 27: Glendon. A World Made New. 174. 
Declaration may be interpreted as implying for any State, group, or person any right to engage in any activity or perform any act aimed at the destruction of any of the rights and freedoms set forth herein.” This article thus forbids any actions aimed at the imperilment of the rights and freedoms listed in the Declaration. In that sense, it forms a general limit to the legitimate exercise of our freedom.

As briefly mentioned in the previous section, Thomas Pogge maintains that Article 28 ("Everyone is entitled to a social and international order in which the rights and freedoms set forth in this Declaration can be fully realized.") contains a right to an international politico-economic order that is not (as is instead the case at present) organized in such a manner that leads to a systematic violation of human rights worldwide. Though this is not at all an implausible reading of this article, it does not shed any light on Article 29. Therefore, we may, for present purposes, consider Article 28 as a "mini-Preamble" instead, as Glendon proposes. ${ }^{51}$ Several aspects of the order mentioned in Article 28 are presented in paragraphs 1 and 2 of Article 29:

(1) Everyone has duties to the community in which alone the free and full development of his personality is possible.

(2) In the exercise of his rights and freedoms, everyone shall be subject only to such limitations as are determined by law solely for the purpose of securing due recognition and respect for the rights and freedoms of others and of meeting the just requirements of morality, public order and the general welfare in a democratic society.

Firstly, it must be an order that renders possible the free and full development of one's personality. Secondly, the order must guarantee safety and security for those who live in it. Thirdly, this order must promote the general welfare and, fourthly, its political system must be democratic in nature. The duties and limitations mentioned in these two paragraphs therefore come into play only to help promote and protect these qualities of the political and social order in question. Thus, we all have duties to the community, but only to a community that renders "the free and full development" of one's personality possible. Similarly, rights are subject to certain limitations, but only "for the purpose of securing due recognition and respect for the rights and freedoms of others and of meeting the just 
requirements of morality, public order and the general welfare in a democratic society." Put differently, one would owe no duties to a community that renders the free and full development of one's personality impossible. Furthermore, any limitations on rights and freedoms for any reasons other than those listed in the second paragraph are illegitimate. It would seem, therefore, that the distrust expressed by critics of individual duties to the community (as discussed in \$1.2) is unwarranted in the case of the Universal Declaration. For so long as the duties and the limitations on the exercise of our rights enjoy such conditions to their validity, any abuse by an authoritarian regime seems highly unlikely.

So far we have established only that duties and limits to rights need not be the plaything of despots. We have thus, as yet, only made the negative case that there is no harm in adopting such duties and limits to rights. Next we must provide a positive argument for such adoption. We have already explained, in other words, why we need not reject duties to the community; now it is time that we clarify the importance of accepting them.

In a sense, the inclusion of Article 29 could be read as a response to the Marxist critique of human rights. In On the Jewish Question Marx criticizes the human rights declarations of the late eighteenth century for what he considers to be their basic assumption, namely that man is an inherently selfish creature. The idea of human rights, Marx maintains, presupposes a view of man not as a citizen who with his fellow citizens attempts to realize a common good, but rather as a "bourgeois," i.e. a self-interested member of civil society. Accordingly, Marx maintains that the "right of man to freedom is not based on the union of man with man, but on the separation of man from man. It is the right to this separation, the rights of the limited individual who is limited to himself." 52 Human rights are intended, thus Marx's critique runs, merely to guarantee for all a private sphere into which each can withdraw from the community [Gemeinwesen], and in which each knows his private interests and whims to be secured. The rights of man view man not as a social being, but rather society "appears as a framework exterior to individuals, a limitation of their original self-sufficiency." 53

Article 29(1) clearly distances itself from such a view by arguing that only in a community can one freely and fully develop one's personality. In fact, the Declaration as a whole emphasizes solidarity and the importance of community: the very first sentence of the Preamble speaks of one human family, Article 1 
summons us to "act towards one another in a spirit of brotherhood," and the Declaration ends by once more emphasizing the importance of community in Article 29(1). We thus find, both out the outset and at the close of the document, calls to solidarity. The drafters expressed the importance they attached to the community by the insertion of one word in particular, according to Morsink: the word "alone" in Article 29(1). He even goes so far as to state that this word may perhaps be the most important of the whole Declaration. ${ }^{54}$

It was the Australian delegate Alan Watt who proposed to add the word "alone" to Article 27 (later to become Article 29), so that eventually Article 27(1) of the Third Committee Draft read as follows: "Everyone has duties to the community in which alone the free and full development of his personality is possible" (my emphasis). Watt's proposal sparked a philosophical debate among the delegates centered on the question whether it was possible to develop one's personality in complete isolation from others. Those who answered this question affirmatively and those who answered it negatively both referred to Daniel Defoe's Robinson Crusoe to make their case. Those who opposed the insertion of the word "alone" argued that Defoe's tale showed how one could very well develop one's personality on a deserted island, whereas those in favor of the addition argued that Robinson had been able to develop his personality merely because he had had certain artifacts of human civilization at his disposal (e.g. books and tools), which he found in the ship's wreckage. ${ }^{55}$ The stakes of this debate were of course not limited to a textual exegesis of Defoe's work; rather, what was at stake was the matter of how the drafters wished to depict the relation between individual and society. By eventually adopting the proposal (23 voted in favor of adoption, 5 against and 14 abstained), the drafters essentially voted to present a particular image of the rights-bearer. By stating clearly that the individual can only develop himself fully in a community, the drafters rejected the image of the lone rights-bearer, isolated from society, for whom his fellow men form "not the realization but the limitation of his own freedom." 56 They instead viewed the rights-bearer as clearly situated within and a part of a particular community, in which alone he is able to develop his personality.

Yet, it is of course not only a matter of the individual depending on the community for its preservation and development, but rather the community itself also depends on its members for its maintenance and flourishing. Therefore, 
the drafters strove to strike a balance between the rights of the individual and the rights of the community or, in other words, between individual rights and individual duties. Given this interdependence of the community and its members, individual freedom had to be balanced with the freedom of others as well as with the reasonable demands of the community. ${ }^{57}$ The rights listed in the Declaration are thus not all understood as trumps. ${ }^{58}$ The drafters expressed this view in the first two paragraphs of Article 29, which together provide guidelines for the achievement of the right balance between the "due recognition of individual human rights and the acknowledgement of individual duties to the community," 59 whereby the community is understood both as an overarching whole and as a collection of its individual members.

Earlier we said that the concerns of the critics of human duties declarations do not apply to the duties expressed in the Universal Declaration, as we owe such duties only to a certain kind of community (one that renders the free and full development of one's personality possible). We noted, furthermore, that not all limitations of rights are legitimate; rather, only those limitations are legitimate that respect the conditions listed in the second paragraph of Article 29. Other critics, however, would argue that the attention dedicated to individual duties and to the individual's place in the community does not go far enough. These critics argue that the discourse of universal human rights is an essentially Western discourse that promotes an individualistic view of man detached from his community. This critique had already been articulated by Marx, as briefly expounded above, but more recently it has especially been expressed by scholars and politicians from African and Asian nations. Thus, the Kenyan-born Makau W. Mutua, pointing out that Africa was not represented at the drafting table of the UDHR, states that it is a decidedly Eurocentric document. According to Mutua, this Eurocentrism translated itself chiefly into an unbalanced view of the individual. He argues that human rights discourse in general, which includes the Universal Declaration, elevates the individual above the society in which she finds herself:

This runaway notion of individualism, which is a central tenet of liberalism, has retarded the capacity of human rights thinkers to moder-

57. Daes. Freedom of the Individual under Law. 19.

58. Certainly there are absolute rights: the right to not be enslaved by another, for example, or the right not to be tortured. In the case of other rights, however (e.g. the rights to freedom of expression, freedom of religion, freedom of assembly, freedom of movement, as discussed in §1.3.1), rights must be balanced with the rights of others and the interests of the community, or the common good.

59. Hodgson. Individual Duty within a Human Rights Discourse. 91. 
ate selfishness with community interests. In other words, the individual should be placed within the society and constructed in such a way that he does not overwhelm his fellow beings or the society itself. ${ }^{60}$

Such criticism, I argue, does not hold against the Universal Declaration. The individual is, firstly, clearly placed in a community, without which it cannot fully develop its personality and to which it has certain duties. Furthermore, selfishness is moderated, namely by placing clear limits on the legitimate exercise of our rights and freedoms, for the benefit of the rights of others, public order and general welfare.

An examination of Article 29 and its drafting history has thus shown that the drafters were very much at pains to strike an adequate balance between the individual and the community in which she lives as well as between her rights and her duties. The individual is deemed neither inferior nor superior to the community, but rather an interdependence between the two is posited. Thus both the criticism that individual duties to the community form a prelude to authoritarianism, and the critique that the individual enjoys absolute freedom at the cost of the community, have been demonstrated to be unfounded in the case of the Universal Declaration.

Thus far we have shown why the duties mentioned in Article 29 are not to be feared and why they help reject the criticism that the UDHR promotes an individualistic image of man. Next, I wish to ascertain with what concrete goal the drafters included such duties to the community.

In Chapter 1 we had already briefly mentioned that the UDHR is not, strictly speaking, a legally binding document. Legislative action being thus left out as the Declaration's chief end, the drafters instead emphasized the Declaration's educational purposes. ${ }^{61}$ Morsink argues that this emphasis on education is clearly expressed in the document's Proclamation. ${ }^{62}$ Granted, the Proclamation does speak of "progressive measures, national and international, to secure their [i.e.

60. Mutua. M. W. (2008). Human Rights in Africa: The Limited Promise of Liberalism. African Studies Review, 51(1), 17-39. 32. Cf. Mutua, M. W. (1995). The Banjul Charter and the African Cultural Fingerprint: An Evaluation of the Language of Duties. Virginia Journal of International Law, 35, 339-380.

61. Morsink. The Universal Declaration. 323.

62. "Now, Therefore, THE GENERAL ASSEMBLY proclaims THIS UNIVERSAL DECLARATION OF HUMAN RIGHTS as a common standard of achievement for all peoples and all nations, to the end that every individual and every organ of society, keeping this Declaration constantly in mind, shall strive by teaching and education to promote respect for these rights and freedoms and by progressive measures, national and international, to secure their universal and effective recognition and observance, both among the peoples of the Member States themselves and among the peoples of territories under their jurisdiction." 
of the rights and freedoms expressed in the Declaration] universal and effective recognition and observance," which appears to point towards their legal implementation. Yet, the Declaration itself was not intended to have legal effect. It calls for the adoption of measures, including those of a legal nature, that can help secure human rights, which it itself, apparently, cannot do. For this reason, the UDHR was intended, from early on in the drafting process, to be complemented by a Covenant, which was to be binding upon the signatories. ${ }^{63}$ Before the passage quoted above, however, the Proclamation states the Declaration's explicitly educational goal, namely "that every individual and every organ of society, keeping this Declaration constantly in mind, shall strive by teaching and education to promote respect for these rights and freedoms."

Morsink appears to view the Declaration's main educational function to be to provide people everywhere with a standard, against which they can judge their government's policies. ${ }^{64}$ There is, however, another, equally important educational function served by the Declaration, to which he grants but cursory mention. The Proclamation calls on all members of society to keep the UDHR "constantly in mind." The Declaration must, in other words, be internalized. Glendon, quoting two of the most influential delegates (Charles Malik and René Cassin), argues that the drafters believed that the best defense of human rights resided not in legal coercion, but rather in the adoption of these human rights and human duties "in the mind and the will of the people." ${ }^{65}$ Cassin added that "respect for human rights depends first and foremost on the mentalities of individuals and social groups." ${ }^{\circ}$ Rendering human rights secure in a stable fashion thus requires more than legal coercion alone; it also calls for the cultivation of a certain disposition or character, for the internalization of certain values. It calls, in brief, for civic virtue. ${ }^{67}$

63. Eventually two separate covenants were drawn up, the ICCPR and the ICESCR, which were both adopted in 1966.

64. Morsink. The Universal Declaration. 324.

65. Malik, C. H. Introduction. In Nolde, O. F. (1968). Free and Equal: Human Rights in Ecumenical Perspective. Geneva: World Council of Churches. 70. Quoted in Glendon. Knowing the Universal Declaration. 1170.

66. Cassin, R. (1972). La Pensée et l'Action. Boulogne-sur-Seine: Editions F. Lalou. 155. Quoted in Glendon. Knowing the Universal Declaration. 1170.

67. Note the similarity with the appeals for "voluntary self-obligation" and a global ethic, as we found them in several of the human duties declarations. These aspects were nearly unanimously denounced by human rights scholars as paternalistic: not only could the government demand obedience to the law, but it could also demand that citizens be virtuous. All the more surprising, then, that we find a very similar call for civic virtue in the Universal Declaration. It would seem that the drafters of the Universal Declaration would have found themselves in agreement with the drafters of the recent human duties declarations concerning the point that legal rights without morality cannot long endure and that, therefore, voluntary self-obligation is needed. 
One can imagine why such a disposition is especially important in the case of human rights, for often the protection of human rights cannot rely on an effective legal remedy. In such cases, it is crucial that ordinary citizens and government officials alike have internalized the value of human rights, which can guide their behavior in the right direction, even in the absence of effective legal enforcement. ${ }^{68}$ Otherwise, in the absence of both legal force and correct dispositions, nothing withholds us from acting as contemporary incarnations of the shepherd-become-king Gyges, of whom Glaucon speaks in Plato's Republic. ${ }^{69}$

This formative function of the Universal Declaration is underscored, furthermore, by the second paragraph of Article 26, the first paragraph of which recognizes everyone's right ${ }^{70}$ to education. The second paragraph stipulates that the education provided ought to be of a certain kind. It was Mr. Bienenfeld, the representative of the World Jewish Congress, who urged members of the Commission to specify the spirit of the mandatory education. He pointed out that though Germany and other fascist countries (such as Italy) had rendered the right to education universal,

yet the doctrines on which that education had been founded had led to two world wars. If the Declaration failed to define the spirit in which future generations were to be educated, it would lose its value as a guide for humanity. The Declaration was not merely an appeal to the State; it was an appeal also to parents, teachers and educators. It was necessary to stress the importance of the article devoted to the spirit of education, which was possibly greater than that of all the other articles of the Declaration. ${ }^{71}$

The delegates appeared to be sensitive to Bienenfeld's plea, as becomes clear in Article 26(2):

Education shall be directed to the full development of the human per-

68. Jeremy Waldron makes a similar point in arguing for the necessity that people be educated to the "cosmopolitan dimension of their civic responsibibilities:" "if anything, the absence of a coercive institution to secure and sustain necessary structures of life and practice at a global level ... makes it all the more important for us to use 'citizens of the world' as an idea regulating our actions" (Waldron, J. (2003). Teaching Cosmopolitan Right. In K. McDonough \& W. Feinberg (Eds.), Citizenship and Education in Liberal-Democratic Societies (pp. 23-55). Oxford: Oxford University Press. 41).

69. Plato. The Republic. Book II. 117ff.

70. In fact, Article 26(1) also contains a duty: "Elementary education shall be compulsory" (emphasis added).

71. UN Doc. E/CN.4/SR.67. (25 June 1948). 13. 
sonality and to the strengthening of respect for human rights and fundamental freedoms. It shall promote understanding, tolerance and friendship among all nations, racial or religious groups, and shall further the activities of the United Nations for the maintenance of peace.

Education must therefore not only teach children mathematics, languages, science, and so forth, but must also create a certain kind of citizen, one that is tolerant, understanding and disposed to friendly relations with her fellow citizens as well as with other peoples. Education must, in other words, instill both civic and cosmopolitan virtue, the latter of which would consist in a set of dispositions and character traits that make us sensitive to the idea that our duties are not limited to our fellow citizens but indeed extend to humanity as a whole. ${ }^{72}$

Having established the important educational function of the Universal Declaration and how this was envisioned by its drafters, we may infer that the duties to the community in Article 29(1) were not (all ${ }^{73}$ ) meant as legally enforceable duties; rather, Article 29 aims to contribute to the cultivation of a certain kind of citizen, namely one who does not only insist on the respect and protection of her rights, but one who also realizes that she is dependent on the community in which she finds herself for her full development as a person, and to which she therefore owes certain duties. We have seen, furthermore, that it is the task of the educational system to instill in citizens such a disposition, or civic virtue.

Thus far, we may conclude that, at least with regard to their function, individual duties to the community are quite worked out. The precise content of these duties, however, still eludes us. What exactly are "duties to the community?" And what is meant by "community?"

\section{$\S$ 3.2.3 - What Duties?}

Neither the final version of the Universal Declaration nor its travaux préparatoires offer much insight into the exact content of the duties to the community mentioned in Article 29(1). In 1998, precisely fifty years after the adoption of the Universal Declaration, the UN General Assembly adopted the Declaration

72. Smith, W. (2009). The Transformation of Political Community and Conceptions of Global Citizenship. In P. Hayden (Ed.), The Ashgate Research Companion to Ethics and International Relations (pp. 461-477). Surrey: Ashgate. 472.

73. Some duties to the community could, in fact, be legally enforceable duties. The duty to obey the law, to vote, and to work are some examples. 
on the Right and Responsibility of Individuals, Groups and Organs of Society to Promote and Protect Universally Recognized Human Rights and Fundamental Freedoms. Article 18 of this document further considers duties to the community. Its first paragraph is nearly a literal quote of Article 29(1) UDHR. Interestingly, the second paragraph elaborates on these duties "towards and within the community:" "Individuals, groups, institutions and non-governmental organizations have an important role to play and a responsibility in safeguarding democracy, promoting human rights and fundamental freedoms and contributing to the promotion and advancement of democratic societies, institutions and processes." This somewhat clarifies the role played by individual duties to the community, but we still do not know which duties exactly are meant.

Perhaps Cassin's revision of Humphrey's text can shed some light on this matter. In the third article of this text Cassin mentions four "fundamental duties" each of us owes to society, namely "obedience to law, exercise of a useful activity, willing acceptance of obligations and sacrifices demanded for the common good." ${ }^{\prime 4}$ From these four duties Cassin mentions, I will distill and clarify three categories of duties to the community: civic duties of justice (to which both the duty of obedience to law and the duty to exercise a useful activity belong), sacrifices demanded for the common good and the duty to perform one's duties willingly. Subsequently, the status of each of these duties will be determined. All, save for the civic duties of justice, will be deemed duties of virtue. Finally, I will suggest that the community referred to in the phrase "duties to the community" is primarily the (national) political community. Accordingly, we may refer to these duties to the community as "civic duties."

\section{Civic Duties of Justice}

The first two duties listed by Cassin present us with duties to the community that are relatively unproblematic. ${ }^{75}$ We could even determine the status of these duties rather easily. These duties are determinate as well as claimable, rendering them perfect. They, furthermore, concern only outward actions. We may there-

74. UN Doc. E/CN.4/AC.1/W.2/Rev.2 (20 June 1947).

75. This is not to dismiss the immense quantity of literature on political obligation of course, nor the fact that several scholars have argued that political obligation cannot be legitimized (see, inter alia: Wolff, R. P. (1998). In Defense of Anarchism (2nd ed.). Berkeley: University of California Press; Simmons, A. J. (1979). Moral Principles and Political Obligations. Princeton: Princeton University Press; Raz. The Morality of Freedom.). I am not interested in questions of legitimization here, however, as that would require an entire book unto itself. Rather, my point is merely that this duty is unproblematic as far as the question of its status as a duty of justice is concerned. 
fore refer to them as civic duties of justice. ${ }^{76}$ Let us take the duty to obey the law, or political obligation, as an example. It is determinate, in the sense that it is clear who must do what for whom, namely all citizens must perform the duties prescribed by clearly worded and publicly accessible laws. Now, the question to whom we owe the duty to obey is one with the question of its claimability: those to whom we owe the duty in question are those who may (indirectly) claim its performance from us. According to the principle of fair play, it is my fellow citizens who have a claim on me; it is to them that I owe this duty.

This principle of fair play, as first developed by Hart and Rawls, ${ }^{77}$ is quite straightforward. The point of departure is the presence of a social scheme of cooperation that is both mutually beneficial and just. The benefits yielded by this social scheme can only be procured if all, or (and this is where the problem of free riders enters the picture) nearly all, cooperate. When one accepts the benefits provided by such a scheme, and one intends to continue doing so, then one has an obligation to do one's part and cooperate, even when one's own cooperation is not specifically necessary for the maintenance of the scheme (as it will not collapse if you alone do not contribute and simply receive the benefits for free). According to this principle, we therefore owe our obligation to obey the law to our fellow citizens, that is, to those with whom we form a political community. They, in turn, have a right to our obedience, because they have rendered it possible for us to enjoy the benefits of the political community (in this case the rule of law) through their obedience. By enjoying this benefit, we incur an obligation to reciprocate by cooperating as well, that is, by obeying the law (provided, of course, that the laws are minimally just) ${ }^{78}$

The duty to exercise a useful activity could be approached in a similar fashion. It is clear who (namely all of us) must do what (exercise a useful activity/

76. I will explain why I refer to duties to the community as "civic duties" at the end of this subsection.

77. Here I draw from Hart's and Rawls's descriptions of the principle of fair play: Hart. Are There Any Natural Rights? 185; Rawls, J. (1999). Legal Obligation and the Duty of Fair Play. In S. Freeman (Ed.), Collected Papers (pp. 117-129). Cambridge, MA: Harvard University Press. 122-3.

78. For reasons of brevity, I am not able to provide a complete defense of our political obligations and the principle of fair play. I merely wish to add here that a common criticism against the principle of fair play, as provided by, e.g., A. John Simmons, concerns the point of viewing our obligations as owed to the community because the benefits are the product of a cooperative venture. Thus, Simmons holds that the principle of fair play fails to justify political obligations, because most of us simply "do not regard the benefits of government as the product of a cooperative scheme," but rather as something that we purchase from the government through paying taxes. Therefore, Simmons continues, many feel that "if debts are owed at all, they are owed not to those around us, but to our government" (Simmons. Moral Principles and Political Obligations. 139). I would argue, however, that this critique is not so much a critique of the fair play justification of political obligations, but rather a critique (unintentionally, to be sure) of how we perceive ourselves and those with whom we live in a political community. All this criticism therefore does is confirm the necessity of cultivating civic virtue, that is, to see ourselves as participating in a common endeavor. 
have a job) for whom (according to the principle of fair play, we owe this duty to do our fair share and avoid being free riders to our fellow citizens). Of course, "failure" to fulfill this duty when one becomes unemployed does not lead to a forfeiture of one's right as a citizen to unemployment benefits, but note that the duty in question remains present in the form of the duty to apply for a job when receiving such benefits.

The duties to obey the law, pay taxes and work are therefore determinate and claimable duties prescribing only outward actions. They are unambiguous duties of justice.

\section{Sacrifices for the Common Good}

Cassin, furthermore, speaks of the duty to perform "sacrifices demanded for the common good." The word "sacrifices" perhaps evokes images of dying heroically on the battlements for one's country, but the sacrifices need by no means be so extreme. One can also imagine that Cassin had more prosaic sacrifices in mind, such as duties of civic participation ${ }^{79}$ - e.g., duties of political participation (comprising, e.g., the duty to vote and to attend neighborhood assemblies), the duty to be informed about current affairs, and the duty to address patent injustices (by writing to one's representatives, starting or supporting a petition, organizing or participating in a protest) - and duties to render civil or military service. ${ }^{80}$

The status of this second category of duties to the community is less clear. It seems that many of these can be conceived both as duties of justice and as duties of virtue. Whether we place these duties in the sphere of justice or in the purview of virtue is therefore a political decision, as both are viable options. Consider the duty to vote. Some countries have made this a legal duty, whereas other countries count on people making their way to the voting booth of their own accord. Throughout Western democracies (those without a legal duty to vote), voting turnout percentages are frighteningly low, in some cases almost as low

79. Here one sacrifices one's time and effort for the common good. One imagines that such civic participation results in a better functioning of the democratic community one is a part of.

80. Examples of such duties to the community can be found in Article XXXIV ADRDM, which states that every able-bodied person has a duty to "render whatever civil and military service his country may require for its defense and preservation, and, in case of public disaster, to render such services as may be in his power." The ECHR does not contain separate articles prescribing such duties to the community, as the ADRDM does. However, in Section 3 of the article prohibiting slavery and forced labor, it states that that the term "forced and compulsory labor" does not apply to military service (or the alternative civilian service for conscientious objectors), "any service exacted in case of an emergency or calamity threatening the life or wellbeing of the community" and "any work or service which forms part of normal civic obligations" (Article 4(3) ECHR). Even the ECHR, therefore, recognizes not only duties to exercise one's rights in a responsible fashion, as expounded in Chapter 1, but also such duties to the community. 
as $50 \% .{ }^{81}$ One imagines that at a certain point - though it is difficult to determine where that point lies exactly - the percentage will be so low as to endanger the electoral system. For this reason, some have argued in favor of compulsory voting: "If a system of open and free elections is in the interests of the citizens, then every citizen must have both an obligation to do his or her part to maintain the system and a right to expect the others to do theirs." ${ }^{2}$ If one benefits from an electoral system that is maintained thanks to the participation of others, then one owes one's fellow citizens an obligation to reciprocate, based on the duty of fair play, which can be fulfilled by casting one's vote. It is, therefore, perfectly possible to conceive of the duty to vote as a duty of justice, as the duty is both determinate and claimable.

However, one may wonder whether the imposition of a duty to vote in fact contributes to the preservation of a system of equal spheres of freedom, which is the task of justice. Many argue that it does not, and that such a duty, instead, diminishes freedom. They will, accordingly, prefer to view voting as a civil right rather than a duty: I may indeed decide to exercise my right, but I may also choose not to do so. Perhaps I am a Jehovah's witness desiring to maintain my distance to earthly affairs; perhaps I am a devoted follower of Rousseau and accordingly believe representation to be tantamount to the abrogation of freedom; ${ }^{83}$ or maybe I would simply, inspired by Melville's character Bartleby, "prefer not to" vote. Whatever the reason may be for my wish to stay away from the polling station, the imposition by the state of a duty of justice to cast my vote could be viewed as illegitimate state interference. Some might argue that such imposition reveals the state's perfectionist leanings: in other words, that the state wishes to foist its understanding of the good life, understood as the life of the active citizen, on its subjects. Others might have more practical concerns with a legal duty to vote. Kymlicka, for example, holds that the imposition of a legal duty does not guarantee the responsible fulfillment of this duty: ${ }^{84}$ people might be completely ignorant on current affairs, easily swayed by populists, or simply

81. In Chapter 5 (Section 5.1.2) the problem of low voter turnout rates will be more elaborately discussed.

82. Dagger, R. (1997). Civic Virtues: Rights, Citizenship, and Republican Virtues. Oxford: Oxford University Press. 149. Cf. Rawls. Legal Obligation and the Duty of Fair Play. 127.

83. Rousseau, J.-J. (1997). Of the Social Contract. In V. Gourevitch (Ed.), V. Gourevitch (Trans.), The Social Contract and Other Later Political Writings (pp. 39-152). Cambridge: Cambridge University Press. Bk. III, Ch. 15 [11]: "the instant a People gives itself Representatives, it ceases to be free; it ceases to be." A more contemporary account of this position is provided by Robert Paul Wolff, who argues that in the absence of direct democracy political obligations in general are incompatible with autonomy: Wolff. In Defense of Anarchism.

84. Kymlicka, W. (2002). Contemporary Political Philosophy: An Introduction (2nd ed.). Oxford: Oxford University Press. 303. 
vote for the party that vows to further their private interests. It is a valid question what the value would be of forcing such people to vote. Finally, one could argue that democracies without mandatory voting laws appear to be functioning just fine, even despite the low voter turnout rates. In sum, the necessity to impose what some might view as a rather heavy-handed duty, which interferes needlessly with people's free choice without yielding concrete results, escapes these critics.

Such problems are compounded in the case of the other duties of civic participation, which next to the duty to vote contain further duties of political participation (such as the duty to attend neighborhood assemblies or the duty to become politically active), the duty to be informed about current affairs, and the duty to address manifest injustices. First, by making being a good (i.e. active) citizen legally binding, the government invites suspicion that it has a perfectionist agenda it wishes to impose, thus violating liberal neutrality. Second, one could once again wonder whether such legal duties are necessary in order to achieve and maintain a vibrant political community. Third, the question remains whether imposing legal duties of civic participation will produce the desired (i.e. public-spirited) form of participation. Is it not possible that citizens will, instead, participate irresponsibly? A majority could use its newfound civic literacy to (further) marginalize a minority. The healthy could decide to cut back on aid to the bedridden and use the funds to advance their own goals. Thus, though it may be possible to render these duties of civic participation legally enforceable, it does not seem an appealing option. Despite the fact that the performance of duties of civic participation is desirable, ${ }^{85}$ rendering such participation legally obligatory might miss its goal: after all, such a considerable interference of the state with the individual freedom of its citizens, which, moreover, could be viewed as a perfectionist policy measure, might also stir resentment. All this is a rather high price to pay when the possible positive effects could also be attained through other means, without imposing legal duties of civic participation. The government may rather decide to encourage civic participation by, for example, teaching about its importance in school and by providing information on possible forms of civic participation in one's neighborhood, city or country.

Thus far, we have seen that the first category of duties to the community consists of evident duties of justice. The performance of the duty to obey the law, for example, may not be left up to the discretion of each citizen (whether to obey, which laws one will obey and which not); its performance must instead 
be secured. Accordingly, the state may and must enforce such duties through legal means. By contrast, we saw that many duties of the second category can be viewed both as duties of justice and as duties of virtue. For example, the duty to vote and the duty of military service are possible duties of justice. Yet, the preservation of the political community does not depend on enforcing them by legal means: the protection of borders does not depend on a legal duty of military service (as countries with a professional army are capable of defending their borders effectively as well), nor is the enforcement of the duty to vote necessary for the maintenance of a democratic state. Accordingly, I will propose to view these duties as duties of virtue. The same goes for the duties of civic participation. The imposition of such duties as legally enforceable duties of justice would be a rather heavy-handed curtailment of citizens' individual freedom, particularly because such imposition is not necessary as it is possible to reach the same result (the performance of duties of civic participation) through other means.

\section{Civic Virtue}

Cassin's penultimate duty - the "willing acceptance of obligations" - will be considered last here, because it applies to all the duties to the community he lists. The word "willing" indicates a particular internal disposition on the part of the citizen: not only must one accept certain duties, but one must also accept them willingly. Not only must we perform our duties, but we must also perform them from the correct motive, that is, from the settled disposition to give precedence to the common good over one's own personal interests. This duty requires, in other words, civic virtue.

With regard to this duty, the problem is that, as Kant would argue, the adoption of maxims for action is an internal affair and can only be achieved by free self-constraint. Therefore, the willing acceptance of duties can be neither externally enforced, nor ascertained. Consequently, neither the state nor one's fellow citizens can demand by right that one perform one's duties (to the community or otherwise) from a particular motive, as we understand having a right as the ability to legally bind the freedom of choice of another. ${ }^{86}$ The duty to perform one's duties from a particular motive can therefore only be placed among the duties prescribed by virtue, which, after all, are not indifferent concerning the motive from which one acts (as duties of justice are), but rather require one act from a particular disposition. 
Save for the first category of duties to the community, I have therefore argued that we ought to place duties to the community within the realm of virtue. This classification, however, should not be interpreted as a rejection of any role for the state in the promotion of the performance of duties to the community and in the cultivation of civic virtue (as will be elaborately argued in Chapter 5).

It would thus appear that the duties to the community of which the Universal Declaration speaks consist of three kinds of duties: first, there are duties to the community that may and can be enforced - such as the duties to obey the law (Cassin's first duty), pay taxes, and exercise a useful activity (Cassin's second duty) -, to which I have referred as civic duties of justice. Few would disagree that these are (and ought to be) part of the sphere of justice. Second, there are "sacrifices demanded for the common good." Cassin does not spell these duties out, but I have suggested, basing myself in part on duties to the community mentioned in the American Declaration and the European Convention on Human Rights, that they may include such duties as military (or civil) service, duties in the face of an emergency and duties of civic participation. Third, there is a duty to accept one's duties willingly. This duty points toward the necessity of civic virtue.

Now that we have a clearer idea of the duties involved when we speak of "duties to the community," we can also render explicit what "community" is intended. Duties to obey the law, pay taxes, duties of political participation and to perform military or civil service: in what context do these duties operate? It seems evident that they operate on the level of the (national) political community. The political community is not, however, a synonym for the state. Rather, the state functions as the representative of the political community. It is for this reason that, from now on, I will also refer to duties to the community as civic duties. Furthermore, these civic duties are owed to one's fellow citizens and only indirectly to the representative of the citizens, i.e. the state. Thus, where we earlier spoke of duties to the community as vertical duties, largely following the lingo of human rights scholars critical of civic duties, it would now appear that they are actually horizontal duties, owed to one's fellow citizens.

Lastly, it should be clear by now (given the discussion of the first two paragraphs of Article 29 UDHR in the previous subsection) that duties to the community are not owed to just any political community. Rather, we owe such civic duties only to a community that respects the conditions set out in Articles 29(1) and 29(2), in other words, a political community that renders possible the free and full development of our personality, guarantees the safety and security of its denizens, promotes general welfare and is a democracy. 


\section{$\S 3.3$ - Conclusion}

This chapter set out to shed some light on the two most contentious and unclear duties that we encountered in our discussion of human rights documents and human duties declarations in Chapter 1, namely duties of international aid and duties to the community. It wished to do so from within the (broadly considered) "juridical" context in which they were also promulgated Accordingly, Section 3.1 strove to clarify individual duties of aid to the global poor by consulting the human rights documents themselves (which declare all have a human right to an adequate standard of living), the General Comments of the CESCR, the work of human rights scholars, and the various human duties declarations. The result was disappointing: when it comes to elucidating individual duties to the global poor, none of these sources were able to help us any further; both the precise content of these duties and their status remain entirely unclear. It remains to be seen, in the next chapter, whether an investigation from a philosophical point of view will be more fruitful.

By contrast, the clarification of our duties to the community, in Section 3.2, was rather successful. Our examination of Article 29 of the Universal Declaration provided us with a substantial degree of clarity concerning our duties to the community. We found that duties to the community were considered an integral part of the Declaration from the very start. Article 29 was meant to illustrate how individual rights function in a larger moral context, a context that also includes duties, public order and general welfare. Furthermore, the Universal Declaration rejects, by means of Article 29, the view of the lone rights-bearer for whom the claims of the community are but so many encumbrances, and instead affirms the interdependence between the individual and the political community in which she finds herself.

By elaborating upon the scant hints provided by Cassin's draft of the Universal Declaration, we were, furthermore, able to distinguish three categories of duties to the community: civic duties of justice, sacrifices demanded for the common good and the duty to perform one's duties willingly. Based on the content of these duties we concluded, moreover, that the community in question must be the (national) political community. The duties to the community may, therefore, also be referred to as "civic duties." Finally, we concluded that, save for the civic duties of justice, civic duties ought to be placed within the realm of virtue.

In close connection with the last of these three types of civic duties - the duty to perform one's civic duties willingly -, we found that the Universal Declaration also has a clear educational function. The drafters recognized that pre- 
scribing legal rights and duties is not enough. For rights to be truly secure, it is necessary to educate people and to create a certain kind of citizen. In other words, the instilment of civic virtue is paramount. In this, the drafters of the UDHR found themselves in close agreement with the drafters of the human duties declarations calling for a global ethic and voluntary self-obligation.

Though Section 3.2 has provided several arguments why duties to the community need not be feared, provided they meet certain conditions, many critics will doubtlessly still be skeptical. Therefore, Chapter 5 will provide an instrumental argument for the necessity (and the good) of civic duties (particularly those of civic participation) as well as a separate argument for the importance of the cultivation of civic virtue (necessary for the willing performance of one's duties, that is, from the motive of duty). 



\section{CHAPTER 4 SUBSISTENCE NEEDS AND INDIVIDUAL DUTIES}

If we persist, nevertheless, in speaking of these needs as constituting rights and not merely claims, we are committed to the conception of a right which is an entitlement to some good, but not a valid claim against any particular individual. ${ }^{1}$

In 1972, in an article that became famous, Peter Singer argued that the process of globalization involves consequences of a moral nature that we do not yet fully comprehend: "From the moral point of view, the development of the world into a 'global village' has made an important, though still unrecognized, difference to our moral situation." Over four decades later, philosophers and scholars of human rights law alike are still coming to grips with this state of affairs. Traditional conceptions of justice were developed in a world that certainly knew of international trade and relations, but nonetheless the complete interconnectedness of all areas of today's world is a new relevant factor in the equations of justice and virtue, with which traditional moral theories did not have to grapple. This development forces us to reconsider our understanding of moral responsibility.

The necessity to review our duties also became apparent in the previous chapter. There, in $\$ 3.1$, we found human rights documents, the General Comments of the CESCR as well as the various human duties declarations all wanting when it came to clarifying our individual duties concerning the fulfillment of subsistence needs. The present chapter therefore wishes to supply answers to such questions as the following: What is the content of our duties towards the global poor? Are these individual duties to help the poor positive or only negative? Are these best understood as duties of virtue or as duties of justice that may be enforced by legal means? Are these strict, perfect duties, or wide, imperfect duties? The position I will defend is that most of our duties that stem from subsistence needs, prior to the creation of institutions that can pair specific right-holders to specific duty-bearers, are necessarily duties of virtue. 
Before arriving at this conclusion, however, several steps will need to be taken. Three questions will structure our discussion, each of which will be discussed in its own section. Firstly (in §4.1), we will ask who has what duties in fulfilling subsistence needs: Are our duties limited to refraining from causing harm and offering compensation when actual harm is done, or ought we to lend a helping hand whenever it is in our power to do so? This section will end with an overview of all our individual duties relative to subsistence needs. The second section $(\$ 4.2)$ will need to provide an answer to the question concerning the status of each of these duties. It will apply the definitions of the distinction between perfect and imperfect duties as well as of the difference between duties of justice and duties of virtue (provided in Chapter 2) to the duties presented in $\$ 4.1$. Finally, the third section $(\$ 4.3)$ will endeavor to answer the question whether subsistence needs give rise to a human right to subsistence. Do all human beings always already possess a right to subsistence or is such a right conditional upon it being claimable?

Inevitably, the treatment of these questions will somewhat overlap at times. Still, they will function as anchors, as it were, fixed points around which to structure our query.

The chapter as a whole will, moreover, demonstrate the need and importance of a renewed focus on individual duties. Not only is a clarification of our individual duties long overdue, but it will also become apparent that a concerted focus on our duties will allow us to distinguish more precisely between genuine and spurious rights claims. The decision to specifically discuss duties concerning global subsistence needs in the present chapter will prove fruitful in demonstrating this considerable advantage of the perspective of duties over the perspective of rights.

Finally, this chapter will conclude with a brief reflection on the significance of duties of virtue as a necessary complement to (duties of) justice.

\section{§ 4.1 - Who Has What Duties in Fulfilling Subsistence Needs?}

In this section I wish to provide an overview of our individual duties regarding global subsistence needs. Hereby I will clarify which causes of poverty lead to which duties for whom. The status of these duties will then be determined in the next section. In order to arrive at such an overview, I will discuss several theories of such duties, most notably Peter Singer's interactionist approach, which is focused solely on remedial responsibility, and Thomas Pogge's institutional 
approach, which focuses solely on outcome responsibility. ${ }^{3}$

The only incontrovertible duty we have, on which all authors agree, is the negative duty to refrain from interfering directly with the ability of others to meet their own subsistence needs. If one's actions directly harm this ability, then we incur positive obligations ${ }^{4}$ to remedy the loss we have caused. This is a case in which duties can be assigned by relying on outcome responsibility. This approach to responsibility typically holds that our duties are limited to refrain from causing harm and suffering, though they may involve positive obligations as well in the case one has violated one's original duty of forbearance.

Restricting the scope of our duties to negative duties of forbearance, however, seems rather limited. For this reason, certain authors have made the case for positive duties of aid by relying on remedial responsibility: our individual duties regarding subsistence needs are not limited to mere forbearance, but instead we have a duty to alleviate suffering whenever it is within our means to do so. ${ }^{5}$ Perhaps the best-known example of remedial responsibility can be found in the work of Peter Singer. In Famine, Affluence, and Morality he develops his central moral principle: "if it is in our power to prevent something bad from happening, without thereby sacrificing anything of comparable moral importance, we ought, morally, to do it." ${ }^{6} \mathrm{He}$ subsequently illustrates the validity of this principle by applying it to a concrete case. If I happen to walk by a shallow pond, in which I spot a drowning child, I ought to go into the pond and rescue the child. It is, after all, in my power to prevent something bad (the child drowning) from happening and the costs (getting my clothes wet, perhaps catching a cold) by no means qualify as "anything of comparable moral importance." We can therefore readily arrive at the conclusion that I ought to rescue the child. If we accept this principle in the case of the drowning child, Singer continues, we can also apply it to the problem of global poverty. The citizens of wealthy nations could save many lives threatened by poverty worldwide by contributing money, and doing so would not require the sacrifice of anything equally morally important

3. I borrow the terms "remedial responsibility" and "outcome responsibility" from David Miller: Miller, D. (2007). National Responsibility and Global Justice. Oxford: Oxford University Press. 81. Remedial responsibility is hereby understood to be the "responsibility we may have to come to the aid of those who need help," whether we have caused their need or not, whereas outcome responsibility is the "responsibility we bear for our own actions and decisions."

4. Following authors like Hart and Rawls, I argue it make sense to distinguish here between duties and obligations. Both the mentioned authors argue that we mostly speak of "obligations" when they are voluntarily incurred, that is, when they are a consequence of our actions (see Rawls. Legal Obligation and the Duty of Fair Play. 118; also see Hart. Are There Any Natural Rights? 179n). Conversely, "duties" are held prior to and irrespective of the agent's behavior.

5. Miller. National Responsibility and Global Justice. 231.

6. Singer. Famine, Affluence, and Morality. 231. 
compared to the value of being free from poverty. Yet, how much ought we to give? Singer replies that "we ought to give until we reach the level of marginal utility - that is, the level at which, by giving more, I would cause as much suffering to myself or my dependents as I would relieve by my gifts." 7 Anticipating the criticism that this duty would be too demanding, Singer formulates a more moderate version (though he believes the strong account to be correct): "We should prevent bad occurrences unless, to do so, we had to sacrifice something morally significant." In this version, it is not necessary for us to give until we reach the level of marginal utility, for reducing oneself and one's dependents to that level may be viewed as sacrificing something morally significant.

The utilitarian basis of this argument is clear: "We ought to be preventing as much suffering as we can without sacrificing something else of comparable moral importance." ${ }^{\circ}$ Note that it is hereby irrelevant how global poverty is caused or who has caused it. These questions are deemed beside the point, as the utilitarian position espoused by Singer does not recognize any morally relevant difference between harming and refraining from helping. In the end, the utilitarian Singer is concerned with the total sum. Solving the problem of global poverty is therefore simply a matter of adding and subtracting: that which the wealthy nations have in overabundance must be transferred to the poorer nations until the wealthy nations have reached a point where giving more would have (morally significant) negative consequences for themselves. Thus a position as Singer's, which relies on remedial responsibility, can, in contrast to outcome responsibility, account for positive duties of aid in cases where no one is to blame, as, for example, when a country is struck by a tsunami or some other natural disaster. ${ }^{10}$ Those who have the means to help others in need, ought to do so. Conceivably, however, we could still allow for gradations of duty, by taking into account specific circumstances and special relations between people(s). For example, we could argue that those people of country $c$, which has been struck by a natural disaster, who are able to help, have a stronger duty to help their compatriots than other people (from different parts of the world) do. Citizens of countries bordering on $c$, as well as those citizens whose country has close historical ties to $c$, might be next in line, as far as the strength of

7. Ibid. 241

8. Ibid.

9. Ibid. 238.

10. One could make the argument that natural disasters occur more frequently due to climate change or that their impact is magnified by a faulty warning system or by a government that is unable or unwilling to provide sufficient emergency aid. Though there are certainly situations where this is the case, occasions remain whereby acute need is not the result of anyone's fault and whereby, therefore, no appeal can be made to outcome responsibility. 
the duty to aid the inhabitants of $c$ is concerned. These gradations of duties do not, however, imply that others - who are neither inhabitants of $c$ nor of a neighboring country nor of a country that has strong historic ties to $c$ - are exempted of all duties to aid the inhabitants of $c$, provided they are able to do so (it would be odd to place a duty on those who themselves are in need of aid).

Positive duties of aid are, however, not limited to cases such as these, where no one is to blame. It may also occur that the poverty of agent $x$ is a consequence of breaches of agent $y$ 's negative duty of forbearance, which however she refuses to remedy. In such a case, the positive duty to aid $x$ might fall to a third party (z) instead. Again, such a duty cannot be accounted for if one relies solely on outcome responsibility (after all, it is not $z$ who is responsible for $x$ 's indigence). Remedial responsibility, by contrast, simply requires agents to help others whenever it is in their power to do so, irrespective of the cause of others' lack, and thus can account for $z$ 's duty to help $x$. As in the discussion above of our duties to the inhabitants of the calamity-stricken country $c$, there may be gradations of duty here as well, depending on the relation one has to $c$ and its inhabitants.

Both the negative duty of forbearance and the positive duties of aid, discussed above, have relied on what Thomas Pogge has called a traditional, interactionist account of human rights, according to which human rights impose duties on individuals not to harm and duties of aid. The main defect of this position, Pogge maintains, is that it is unable to account for the most important duty regarding subsistence needs, which is institutional in nature. ${ }^{11}$ Our fundamental individual duty corresponding with human rights is, on Pogge's account:

a duty not to contribute to the coercive imposition of any institutional order that avoidably fails to realize human rights, unless one also compensates for one's contribution by working toward appropriate institutional reforms or toward shielding the victims of injustice from the harms one helps produce. ${ }^{12}$

This duty arises from Pogge's institutional approach (which he adopts instead of the interactionist position), which maintains that human rights are in the first

11. It is not my intention to defend Pogge's rejection of the interactionist approach, but merely to present an additional individual duty relative to subsistence needs. I merely mention here, furthermore, that a number of authors have argued that the institutional duty Pogge presents is in fact perfectly compatible with the traditional, interactionist approach. See, for example: Stemplowska. Real World Duties.

12. Pogge. Human Rights and Human Responsibilities. 166; cf. Pogge. World Poverty and Human Rights. 73. 
place claims on social institutions and in the second place claims on all those who are involved in maintaining such institutions. ${ }^{13}$ Given that the world in which we live constitutes a global institutional order, it follows, furthermore, that the duty here described falls on all persons everywhere, but especially on the more influential and privileged,${ }^{14}$ because they presumably have contributed to and benefited from this institutional order more than others. The citizens of wealthy nations are thus not simply innocent bystanders, but rather they (knowingly or unknowingly) cooperate in a system that causes and maintains poverty in other parts of the world, to their own advantage..$^{15}$ Insofar as we have in this manner caused the harm of others, we are co-responsible for their suffering.

Note that our principal duty regarding others' subsistence needs is a negative duty not to participate in a global system that causes and perpetuates poverty. ${ }^{16}$ It is for this reason, Pogge claims, that his institutional account maintains the middle ground between two extreme positions. ${ }^{17}$ On the one side, minimalist interactional libertarians would argue that we carry no responsibility for violations of rights that we did not cause directly, whereas, on the other side, maximalist interactional utilitarians (such as Singer) hold that we are responsible for all deprivations everywhere as long as we have not given everything we can give, regardless of our causal relation to said deprivations. Pogge maintains the libertarian point that we only have negative duties of justice towards others, without concluding that we therefore have no duties at all towards the global poor. Initially, our duty of justice towards the poor is "merely" to not participate in an institutional order that systematically breaches the right to be free from poverty. Once we have violated this duty, however, we acquire "negative-duty-generated positive obligations"18 to actively work for institutional reform and to provide compensation aimed towards poverty alleviation.

13. Pogge. World Poverty and Human Rights. 50-1.

14. Pogge. Human Rights and Human Responsibilities. 166.

15. In $\S 3.1$ I have briefly pointed out several ways in which the global order favors the wealthy nations, at the expense of poorer countries.

16. It becomes clear here that, as mentioned in $\$ 3.1$, Pogge bases his institutional account of human rights on a particular reading of Article 28 UDHR, which views this article as key to how we ought to understand all rights listed in this document. Accordingly, Pogge explicitly refers to this article when he argues that the justice of "any institutional order depends primarily on its success in affording all its participants secure access to the objects of their human rights" (Pogge. Human Rights and Human Responsibilities. 165).

17. Pogge. World Poverty and Human Rights. 72.

18. Pogge, T. (2005). Reply to the Critics: Severe Poverty as a Violation of Negative Duties. Ethics and International Affairs, 19(1), 55-83. 69: "These positive obligations are generated by a negative duty that is correlative to human rights. Failure to fulfill such positive obligations therefore violates human rights." Pogge appears to be using the term "obligation" in a similar manner as Rawls and Hart (see note 4). 
The major innovation of Pogge's theory of human rights is its institutional approach. The correlative duties are not limited to avoiding direct harm. Instead, we are under a negative duty to refrain from participating in a harmful system. This duty involves informing oneself about the manner in which the global order operates and the effects it has on people's lives. Pogge cleverly claims that he only recognizes such negative duties of justice: we need merely refrain from harming others, whereby the novelty is that harming must be understood in an institutional and not in an interactional manner. His principle of justice has also been referred to as the "cause principle:" ${ }^{19}$ Pogge holds that we are responsible for global poverty, because and only insofar as we have caused it. The almost libertarian appearance of his position regarding global justice is deceptive, however. For the negative duty to refrain from participating in an unjust order is such that it cannot possibly be fulfilled. Unless one withdraws from society entirely, one will be implicated in the preservation of the unjust order and, consequently, inevitably incur obligations to remedy the harm caused and to help push for reform. Given that the negative duty postulated by Pogge can therefore not possibly be fulfilled (as I will argue elaborately in the next section), positive duties were part of his account all along, except for the fact that they now appear in the guise of "voluntarily" incurred obligations.

By merely relying on outcome responsibility, Pogge can thus account not only for the negative duties to refrain from both direct and institutional harm, but also, given that the negative duty of an institutional nature is impossible to fulfill, for positive obligations of aid and reform. What he cannot account for, however, given that he relies exclusively on outcome responsibility, are positive duties of aid in situations where either no one at all is responsible or at least I myself am not to blame. ${ }^{20}$

The above brief discussion of Singer and Pogge, whose two accounts of our duties to the global poor have been extremely influential, has uncovered the various duties we have regarding the fulfillment of subsistence needs worldwide. The goal of this section has not been to judge the status of these duties, which will be undertaken next, but rather to provide a complete overview of

19. Kreide, R. (2007). Neglected Injustice: Poverty as a Violation of Social Autonomy. In T. Pogge (Ed.), Freedom From Poverty as a Human Right: Who Owes What to the Very Poor? (pp. 155-181). Oxford: Oxford University Press. 172.

20. Indeed, this is a very common critique of Pogge's work. See, for example: Gilabert, P. (2005). The Duty to Eradicate Global Poverty: Positive or Negative? Ethical Theory and Moral Practice, 7, 537-550. 538; Kreide. Neglected Injustice. 174-5. Stemplowska. Real World Duties. 479. 
our individual duties arising from subsistence needs. We may distinguish three separate causes of the non-fulfillment of subsistence needs, which trigger either remedial or outcome responsibility resulting in either negative or positive duties (or both): ${ }^{21}$

1) If poverty is caused by a natural disaster, or some other calamity for which no one is to be blamed, then all who are able to help nonetheless have positive duties of aid. The "weight" of the duty, however, may depend on specific circumstances and special relations between people(s). This duty relies on our remedial responsibilities.

2) If the cause of poverty is some directly harmful action (e.g. the burning of agricultural lands by an invading army), then (a) the agent who committed this direct harm has a positive duty to remedy (and, of course, a negative duty to refrain from further harming). Here we can rely on outcome responsibility. If that agent refuses or is unable to remedy the situation, we might (b) pass the positive duties of aid on to other, capable agents, in which case we would rely on remedial responsibility. In this case as well (as with duty 1), we allow for the possibility of different gradations of duties, depending on the specific circumstances and relations between people and countries.

3) In the case of unfulfilled subsistence needs as a consequence of an unjust (global) politico-economic order, we have a negative duty to refrain from participating in that order as well as positive duties of direct aid and reform if we are unable to fulfill our negative duty. These duties are allocated by relying solely on outcome responsibility.

This results in the following schema of all our possible individual duties concerning the fulfillment of subsistence needs: 


\begin{tabular}{|l|l|l|l|}
\hline Cause of poverty & Who has duties? & What duties? & $\begin{array}{l}\text { Basis for according } \\
\text { duties }\end{array}$ \\
\hline $\begin{array}{l}\text { Natural disaster } \\
\text { (no one is to blame) }\end{array}$ & $\begin{array}{l}\text { All, but gradations } \\
\text { of duty and ability to } \\
\text { help are taken into } \\
\text { account }\end{array}$ & Positive duties of aid & $\begin{array}{l}\text { Remedial } \\
\text { responsibility }\end{array}$ \\
\hline $\begin{array}{l}\text { Direct harm } \\
\text { D. }\end{array}$ & $\begin{array}{l}\text { The agent that has } \\
\text { harmed }\end{array}$ & $\begin{array}{l}\text { Negative duties to } \\
\text { refrain from harming } \\
\text { and positive duties to } \\
\text { remedy }\end{array}$ & $\begin{array}{l}\text { Outcome } \\
\text { responsibility }\end{array}$ \\
\cline { 2 - 4 } & $\begin{array}{l}\text { b. } \\
\text { All, but gradations } \\
\text { of duty and ability to } \\
\text { help are taken into } \\
\text { account }\end{array}$ & $\begin{array}{l}\text { Positive duties of aid } \\
\text { b. }\end{array}$ & $\begin{array}{l}\text { Remedial } \\
\text { responsibility }\end{array}$ \\
\hline $\begin{array}{l}\text { 3. } \\
\text { (Global) } \\
\text { institutional harm }\end{array}$ & $\begin{array}{l}\text { All those participating } \\
\text { in the institutional } \\
\text { scheme }\end{array}$ & $\begin{array}{l}\text { Negative duty } \\
\text { to refrain from } \\
\text { participating in unjust } \\
\text { schemes. Otherwise, } \\
\text { positive duties to } \\
\text { remedy and reform } \\
\text { are incurred }\end{array}$ & $\begin{array}{l}\text { Outcome } \\
\text { responsibility }\end{array}$ \\
\hline
\end{tabular}

Figure 1

What this overview does not show, however, is the status of these duties. The question whether such duties are perfect or imperfect, duties of justice or duties of virtue, will therefore be treated next.

\section{§ 4.2 - What Is the Status of Our Duties Concerning the Fulfillment of Subsistence Needs?}

Over two thousand years ago Cicero briefly summarized the problem of our duties to the needy by observing that "the resources of the individual are limited, whereas there is a numberless crowd of those in need of them." 22 Throughout the history of practical philosophy such thoughts have led to the conclusion that our duties to the needy are greatly underdetermined (and potentially overdemanding). Kant would argue that the lack of determinacy stems from the fact that our duties to the needy do not prescribe particular actions, but rather spe- 
cific maxims for action. There is therefore a certain measure of latitude (Spielraum) concerning the manner of their fulfillment: ${ }^{23}$ how one should act, as well as how much one is to do for whom, is not precisely determined. These matters are therefore largely at the agent's discretion. It follows, according to this train of thought, that duties of aid are imperfect.

In Chapter 2, I have traced the historical development of our current understanding of the perfect-imperfect distinction. In brief, we found, firstly, that perfect duties are determinate. Who bears the duty, what the content of the duty is and for whom the duty-bearer must perform it, all this is clearly determined in the case of perfect duties. By contrast, if one of these points remains indeterminate we have to do with an imperfect duty. Thus, when either the duty-bearer has not been identified, the content of the duty has not been specified (leaving the duty-bearer with a measure of latitude concerning the manner in which she will fulfill her duty), or the person for whom the duty must be performed has not been singled out, then the duty in question is imperfect. Secondly, as a consequence of their determinateness, perfect duties are claimable: the right-holder can identify the duty-bearer(s) and claim the performance of a specific duty from her. In the case of imperfect duties, instead, it is not clear how to pair up right-holders and duty-bearers, nor what the content of the duties is precisely. Thirdly, a common point especially in much of contemporary scholarship, imperfect duties are made out to be somehow of lesser importance than perfect duties. This belief becomes apparent, for instance, from the great pains many defenders of subsistence rights go to in order to prove that such rights do not "merely" give rise to imperfect duties, but should instead be situated within the realm of justice. ${ }^{24}$

In examining the four duties from the schema provided at the end of the previous section, I will mainly attempt to answer the question whether the duty under consideration is a duty of justice or a duty of virtue. Though I do not believe these terms to be strictly synonymous with perfect and imperfect duties respectively, I hold (as argued in Chapter 2) that all duties of justice are perfect duties and thus that imperfect duties cannot be duties of justice. ${ }^{25}$ My understanding of duties of justice in relation to rights, furthermore, can be summarized as follows: for there to be a right, there must be a corresponding duty of

23. Kant. The Metaphysics of Morals. Ak 6:390.

24. See, for example Ashford. The Inadequacy of our Traditional Conception. 219-20; Gilabert. Kant and the Claims of the Poor. 394ff. In Chapter 2 I have already extensively argued against this common view that imperfect duties are of lesser importance than perfect duties.

25. That this is a contentious view nowadays is confirmed by the works of Ashford and Stemplowska, both of whom argue for the possibility of enforceable imperfect duties, or imperfect duties of justice: Ashford. The Inadequacy of our Traditional Conception. 234; Stemplowska. Real World Duties. 482. 
justice, the performance of which is owed to the right-holder and the non-fulfillment of which constitutes a wrong, that is, a violation of a right. If, therefore, a duty may be weighed against a different duty, or the agent may freely choose which aspect of the duty to fulfill without committing a wrong, then the duty in question cannot be a duty of justice, but must instead be taken to be a duty of virtue. Consequently, the purported right does not exist. ${ }^{26}$

With these definitions in mind, let us proceed to examine the status of the duty to refrain from (global) institutional harm.

\section{Duty to refrain from direct harm}

I will start with the least contentious of the duties listed in the schema above, namely the duty to refrain from direct ${ }^{27}$ harm and to remedy the harm caused (duty 2.a in Figure 1). The content of this classic Ulpian duty of neminem laedere ("do not harm anybody") is unambiguous: I ought not to harm anyone. Accordingly, violations are easily detected, rendering this duty enforceable. Requiring merely forbearance, this duty can, furthermore, be easily performed by all for all and is thus universal. We may therefore conclude that this universal, perfect duty is indeed a duty of justice. When, however, this negative duty is violated (say the agent is a member of a rebel group and, as such, takes part in the burning of the farmlands of the rebels' enemies), the duty-bearer incurs positive duties (or strictly speaking, obligations) of remedy. Though the content of such duties would need to be specified for each case (depending on the gravity of the offence and, if several agents were involved, one's part in the violation), they are nonetheless duties of justice, as they are incurred as a direct consequence of the violation of the duty of justice to refrain from direct harm. Furthermore, the duty-bearer and the person(s) to whom compensation is owed are clearly

26. Certain authors, such as Iris Marion Young, have introduced a seemingly new concept beyond the distinction between duties of justice and duties of virtue. However, she describes "responsibility" in a manner very similar (not to say identical) to the common understanding of duties of virtue: responsibility, as opposed to duties (on Young's account) "is more open as to what action it calls for." One, furthermore, "has the responsibility to do whatever it takes to bring about specific ends or purposes" (my emphasis). Lastly, she explains that taking responsibility involves the exercise of discretion: "It is up to the agents who have a responsibility to decide what to do to discharge it within the limits of other moral considerations" (Young, I. M. (2013). Responsibility for Justice. New York: Oxford University Press. 143). Yet, all the characteristics she mentions - acting in light of ends, exercising discretion, taking into account other moral commitments - are typical of duties of virtue. It seems, therefore, that the necessity for the introduction of the term "responsibility" arises only as a consequence of the unwarranted conflation of the concept of duty as such (or in general) with duties of justice, thus ignoring the existence of duties of virtue. I, therefore, fail to see the added value of the concept and leave it aside for the remainder of this chapter.

27. Note that we are here speaking only of the duty to refrain from direct harm. The more difficult case of institutional harm will be considered next. 
identifiable. The precise content of such positive duties of reparation could be specified by a court of law, for example.

This seemingly straightforward duty could, however, be rendered more complicated by arguing that the duty to refrain from harming also includes the duty to exercise one's rights in a responsible manner. In a manner analogous to the right to freedom of expression, discussed in Chapter 1, the right to (acquire) property, for example, is limited by the rights of others. If one exercises this right in such a manner that there remains little to nothing left for others, then one has exercised one's right without due respect for the equal rights of others. This Lockean duty ${ }^{28}$ would exclude such practices as land grabbing, i.e. the buying up of enormous swaths of land in developing countries by foreign companies or governments. This example shows how harming by exercising one's right without due respect for the rights of others may also be a perfect duty: no one is permitted to acquire such quantities of land as would endanger the ability of others to fulfill their subsistence needs. This duty requires merely forbearance and can thus easily be performed by all for all; it is therefore universal. The content of the duty is specific enough, though it may, as in the case of the right to freedom of expression, require further fleshing out. As with the right to freedom of expression, whether one has exceeded the limits of one's right to property could be determined case by case by a court of law. In general terms, however, the duty is clear enough to be considered determinate and claimable: everyone has a duty to refrain from acquiring such an amount of property that endangers the fulfillment of the subsistence needs of others. Accordingly, the duty to refrain from harming by exercising one's right to property without due respect for the rights of others is a genuine duty of justice.

\section{Duty to refrain from (global) institutional harm}

This duty lies at the core of Pogge's account of our duties with regard to the subsistence needs of others. It consists in refraining from participating in unjust

28. John Locke argues that one's right to property ought to be exercised in such a manner that does not render impossible the acquisition of a similar amount of property by anyone else: "Labour being the unquestionable Property of the Labourer, no Man but he can have a right to what that is once joyned to, at least where there is enough, and as good left in common for others(Locke, J. (1988). Two Treatises of Government. (P. Laslett, Ed.). Cambridge: Cambridge University Press. 288). He recognizes a further, more famous limitation on property as well. Everyone may acquire as much property "as any one can make use of to any advantage of life before it spoils; so much he may by his labour fix a Property in. Whatever is beyond this, is more than his share, and belongs to others" (ibid. 290). Locke sets this limit as he is convinced that "[n]othing was made by God for Man to spoil or destroy" (ibid.). (It must be noted, however, that for Locke this limit to the accumulation of wealth applies only to the state of nature, prior to the invention of money (ibid. 300-2).) 
orders that foreseeably cause a lack of necessary subsistence goods. By violating this duty, one additionally acquires duties to remedy the harm caused and to push for reform. The negative duty to refrain from institutional harm is the only duty of justice Pogge recognizes (the duties to remedy and reform are in fact obligations incurred only upon violation of one's duty of justice). The reason why, according to Pogge, justice contains solely negative duties, ${ }^{29}$ is because, given certain prejudices about negative and positive duties, he believes the former to be more widely accepted because they are viewed as more stringent and less demanding. Pogge claims that the duty contained in his conception of justice is limited in range, as it involves only persons "subject to an institutional order you cooperate in imposing." In a globalized world, however, this range could potentially encompass everyone. The range is thus not as limited as he lets on. Furthermore, Pogge maintains that this negative duty (including the two positive obligations) is limited in demandingness as well, since it is restricted "to compensation for your share of that part of the human rights deficit that is reasonably avoidable through an alternative institutional design." ${ }^{30}$ It is this supposedly limited demandingness especially that critics have challenged..$^{31}$

Pogge's insistence that justice contains only negative duties is meant to appease critics of subsistence rights who worry that the correlative duties are overly demanding. Indeed, traditionally, negative duties have been held to have certain advantages over positive duties: they require only forbearance (not positive action), they are universally applicable (all can fulfill them towards all), they are enforceable, and their fulfillment is less costly and thus more compatible with maximal liberty. However, it would seem that this asymmetry between negative and positive duties does not apply when the negative duties are of an institutional nature, as in the case of Pogge. Refraining from harming in a globalized world is not so easy as simply refraining from performing acts most of us would not even consider doing anyway (theft, sexual assault, murder). Instead, to refrain from harming others requires our unending vigilance: Is this T-shirt made by a child in a sweatshop? Are these oranges produced in Israeli settlements in the West Bank? Should I take shorter and less warm showers? Should I eat less meat, because the production of meat is an incredibly inefficient use of farmland? Are 
my savings being invested in weapons manufacturers by my bank? Are my taxes being used by my government to wage an unjust war? This is just a fraction of the questions we could ask ourselves every day, but this short list of concerns will suffice to show that not harming demands our constant attention. To completely avoid contributing to and benefiting from the global unjust order thus appears to be a Herculean task. It involves informing oneself about the possible consequences of one's behavior - in collaboration with the actions of many other agents - for people in distant lands whom one has most likely never met. The paradigm of harming has thus become very different from the traditional one, whereby one's actions by themselves are sufficient to cause harm without the contribution of others, and the harmful effects of one's actions are immediate and near. ${ }^{32}$ The advantages of negative over positive duties only apply to this classic picture of harming. Pogge, however, abandons this picture and proposes a new, institutional account without wishing to give up the advantages of the classic account (stringency, reasonable demandingness, universality). His theory is thus presented as far less demanding that it is in reality.

Assuming one is able to figure out all the harmful consequences of one's participation in unjust schemes, the question still remains whether or not one can reasonably avoid participating in such a scheme. The language of negative duty conceals the incredibly complex and demanding nature of this command: to absolutely refrain from consuming any products that have been unfairly produced, for example, would already call for a major lifestyle change. But, supposing one's government is involved in upholding unfair trade agreements, one would even be required to move to a different country, lest one contribute to one's government's harmful practices by paying taxes. If one does not succeed in finding a country with a completely innocent government, a real possibility I imagine, one would have to retreat from society altogether to avoid harming others.

Pogge's negative duty to refrain from institutional harm is therefore far more complex and demanding than the classic duty of forbearance. In fact, one could imagine several positive duties of aid less demanding than Pogge's negative duty to refrain from institutional harm. It is likely that one is, due to human finitude, unable to refrain entirely from doing institutional harm, as it requires a

32. Lichtenberg. Negative Duties, Positive Duties, and the 'New Harms.' 561. Samuel Scheffler makes a similar point when he speaks of the traditional phenomenology of agency that is still dominant: "Within this phenomenology, acts have primacy over omissions, near effects have primacy over remote effects, and individual effects have primacy over group effects" (Scheffler, S. (2001). Individual Responsibility in a Global Age. In Boundaries and Allegiances: Problems of Justice and Responsibility in Liberal Thought (pp. 32-47). Oxford: Oxford University Press. 39). 
considerable amount of informing oneself as well as substantial life changes. It follows that Pogge's negative duty must be viewed as an imperfect duty, allowing the agent considerable latitude in the manner in which and the extent to which she discharges it. ${ }^{33}$ Yet, as mentioned in Chapter 2, such discretion is "not to be taken as permission to make exceptions to the maxim of actions but only as permission to limit one maxim of duty by another (e.g. love of one's neighbor in general by love of one's parents)." ${ }^{4}$ In other words, we do have an imperfect duty to act in light of a certain end - i.e. the end of avoiding institutional harm altogether -, but the manner in which we fulfill this duty allows for a measure of latitude, and may be limited by other duties.

Pogge's duty to refrain from harming is, furthermore, less precise than it seems. Given that it is not always clear what I ought to do to refrain from harming, the content cannot be said to be determinate. Pogge's assertion that we "choose to remain ignorant" 35 of the manner in which the world economy is structured, what role our government has in shaping it, and what consequences it has for others in the world, is - I think - a bit too quick. It is difficult, for example, to hold citizens of wealthy nations responsible for the policies developed by the IMF and the World Bank, given that the "IMF is accountable to finance ministers and central bank governors, and its officers are not elected but rather appointed by agreement of governments." ${ }^{36}$ Debra Satz further points out that the policy debates of these organizations more often than not take place in secret, rendering it more difficult to obtain information. As long as one is

33. In these pages I mention the problem of demandingness several times. It must be noted, however, that my aim in doing so is not to engage in the discussion of how demanding our moral duties in general (understood as comprising both duties of justice and duties of virtue) may be. Rather, my aim is to point out the problem of overdemandingness for a particular set of individual duties, namely duties of justice, which I take to be perfect duties. The problem of overdemandingness for such perfect duties is as follows: I have listed indeterminacy as a characteristic of imperfect duties. If a duty is so demanding that one cannot completely fulfill it, then one must choose which aspects of the duty one will perform. Pogge's negative, institutional duty, under discussion here, fits this description: it is too demanding to be fulfilled completely. We must therefore make choices: I will refrain, for example, from buying clothing that is produced in sweatshops, but I will not move to another country to avoid paying taxes, which my government uses to participate in an unjust war. One must do something, but precisely what aspects of this duty one chooses to perform is at the agent's discretion. For this reason, overdemanding duties are imperfect and should therefore not be understood to be duties of justice. If we would consider overdemanding duties to be duties of justice, then we would have to accept a rather skewed concept of a duty of justice. For, habitually, a duty of justice is viewed as a duty, to the performance of which certain right-holders may constrain certain duty-bearers. If we accept that overdemanding duties may also be duties of justice, then we have to accept the idea of a duty of justice, of which certain aspects may be left unfulfilled at the duty-bearers' discretion - a duty of justice, in other words, that may not be completely claimed by the relevant right-holders. In what sense would such a duty still be a duty of justice?

34. Kant. The Metaphysics of Morals. Ak 6:390.

35. Pogge. Reply to the Critics. 79.

36. Satz, D. (2005). What Do We Owe the Global Poor? Ethics and International Affairs, 19(1), 47-54. $51-2$. 
not entirely clear on the policies of these international financial institutions, the content of one's duties to refrain from participating in an unjust order shaped, in part, by these policies, will necessarily remain indeterminate and the duty itself therefore imperfect.

It is difficult to imagine, moreover, how Pogge's negative duty could be claimable. It would involve a specific victim, often in a different country, seeking out one of the many agents who contributed to the preservation of an unjust order that has caused her harm, as responsible for her condition. What justifies her claim on him specifically, when she might have placed her claim on so many possible others (that have likewise participated in the same order)? This question shows that the pairing of victim and violator, and thus claimability, has become problematic, another indication that the duty in question is imperfect.

The positive duties to remedy harm caused and to push for reform face a similar problem. It seems difficult for a particular person in need of assistance to claim aid or reform efforts from a specific duty-bearer. These positive duties, furthermore, are underdetermined in two ways. The first sense in which they are underdetermined concerns the question how much I ought to do. Pogge answers as follows: "The word 'compensate' is meant to indicate that how much one should be willing to contribute toward reforming unjust institutions and toward mitigating the harms they cause depends on how much one is contributing to, and benefiting from, their maintenance." 37 But how am I to measure how much I have contributed and benefited ${ }^{38}$ And even if I could provide such an exact figure, how ought I then to translate that into aid and reform efforts? This brings us to the second sense in which Pogge's positive duties are underdetermined: it is unclear whom ought I to help first and how much. Where should the focus of my reform efforts lie?

Given the global range of the harmful institutions in which one has participated, the persons for whom one might provide aid or for whose cause one might lobby and undertake reform efforts, are numerous: one could lobby to overhaul the EU agricultural subsidies, which render it impossible for African farmers to compete and make a living, given the extremely low prices of subsidized European agricultural produce. Yet, one could also provide direct aid to victims of an

37. Pogge. World Poverty and Human Rights. 56.

38. A related problem, though of a more epistemic nature, is raised by O'Neill who argues that "the causal links between specific individuals or institutions who injured and were injured . . . are too often not clear enough to allocate rights of compensation (O’Neill, O. (2000). Transnational Economic Justice. In Bounds of Justice (pp. 115-142). Cambridge: Cambridge University Press. 132). Also see Satz. What Do We Owe the Global Poor? 50. 
unjust war in which one's country has participated, or dedicate one's time and effort to any one of the many other cases in which subsistence needs go unmet. Such reform efforts and aid require the seeking out of information about the region in which the problem has occurred, the nature of the problem in question, its causes, and effective ways of helping or reforming. It is possible for an individual to do this for one cause or perhaps two at a time, but certainly not for all the cases in which people suffer from poverty. Duties of aid and reform do not dictate which of these many possible cases I ought to focus on, and human finitude precludes us from fully dedicating ourselves to all of them. Therefore, agents have considerable latitude in deciding which duties of aid and reform they discharge.

Both the negative duty to refrain from upholding harmful institutions and the positive duties resulting from its violation are thus not sufficiently determinate, nor is it clear how right-holders could claim the performance of these duties. As a result, we must conclude that they are imperfect. Indeed, Elizabeth Ashford, whose position is in many ways similar to Pogge's, admits that this is the case: in the absence of just institutions that can allocate and specify the duties, they remain imperfect. ${ }^{39}$ Nonetheless, Ashford maintains, they are (imperfect!) duties of justice. At this point, however, we ought to ask ourselves what we mean when we speak of duties of justice. Unfortunately, more often than not this term is employed without the provision of a clear definition. Often it seems that the term "justice" is simply used in order to convey that something is very important, whereby the possibility that certain duties may be of fundamental importance but are not matters of justice, is rejected out of hand. Indeed, the greater the number of duties that are given the predicate "duty of justice," the more all other duties seem to be devalued. Certain liberals even place the duty to treat "each as an end" within the sphere of basic justice, ${ }^{40}$ while Kant, from whom they presumably borrow this duty, clearly did not view this as a matter of justice, as it fails to fulfill the first condition of justice (namely that it regards only the external actions of individuals, insofar as they can affect others).

We will thus need to define duties of justice more precisely. ${ }^{41}$ The idea that duties of justice are perfect and duties of virtue imperfect has been contested of

39. Ashford. The Inadequacy of our Traditional Conception. 234.

40. See e.g. Nussbaum, M. (2006). Frontiers of Justice: Disability, Nationality, Species Membership. Cambridge (Mass.): Belknap Press of Harvard University Press. 70.

41. I am indebted to Allen Buchanan for the four different distinctions between duties of justice and duties of virtue I discuss here: Buchanan. Justice and Virtue. Buchanan, however, employs the terms "charity" where I speak of "virtue." 
late. Instead, some scholars have made the argument that the imperfect duties under discussion here are duties of justice that ought to be made perfect. ${ }^{42}$ This duty to develop institutional structures that can define and allocate imperfect duties, rendering them perfect and enforceable, is itself imperfect as well. Nonetheless, this too is held to be a duty of justice. Yet, if it is no longer the perfection of duties that places them within the sphere of justice, what criterion for duties of justice is used instead? A second traditional approach to the distinction, found in the work of Pogge and in the writings of most libertarians, holds that only negative duties can be duties of justice. This theory has also been rejected, however, since the positive duties to aid and reform are considered to be duties of justice as well. Alternatively, a third option would be to make an appeal to the claimability of the duties. Yet, again this suggestion is turned down. After all, these scholars regard duties to reform and aid, as well as duties to not participate in harmful institutions, as duties of justice despite the fact that they are not claimable at present. Finally, duties of justice have often been held to be those duties that have corresponding rights. It is this definition to which these authors appeal: the right to an adequate standard of living exists, it is held, because it protects a fundamental human interest. This right then gives rise to duties that, though they are of an imperfect nature, are nonetheless considered to be duties of justice, precisely because they arise from a right. It is the importance of the right in question, furthermore, which leads to calls for institutionalization so as to render the duties perfect, lest the rights remain unfulfilled:

It is therefore not true that an institutional specification of duties is a condition of the right's existence. The right exists, and imposes corresponding obligations, even in the absence of any institutional allocation of duties. In particular, it imposes . . . the corresponding duty to coordinate with others to bring about an institutional allocation of duties that realizes the right, insofar as this is reasonably possible. $^{43}$

Here it must be clarified, however, how the term "right" is utilized in this line of argument. Crucially, this understanding of right does not connect having a right 
to $\mathrm{X}$ with a moral title to limit the freedom of another by claiming the performance of $\mathrm{X}$ from all or specific duty-bearers. After all, prior to institutionalization the right in question (i.e., the right to basic necessities) is not claimable, as it is not clear wherein exactly $\mathrm{X}$ consists, nor is it clear who must provide $\mathrm{X}$ for whom. ${ }^{44}$ Rather, a right to $\mathrm{X}$ seems to give rise to what is referred to as an "imperfect duty of justice" to set up institutions that can make possible the claiming by force of the duties to aid and reform.

On the account I have put forward in Chapter 2, if there is a right, then there must be a duty of justice, ${ }^{45}$ the performance of which is owed to the right-holder and the non-fulfillment of which wrongs her. Conversely, where a duty of justice is absent, there can be no right. A right to subsistence, however - given the impossibility of the negative duty to wholly refrain from participating in unjust institutions - generates duties of aid and reform, which I have argued cannot be performed by all for all. I will thus have to choose whom I will aid and for which cause I will lobby for institutional reform. It seems to me, however, that if I choose to help needy persons A and B, and, due to human finitude, am not able to help all the others who are equally deserving of my help, I do not wrong those that I have not helped. ${ }^{46}$ But if we accept this line of argument, it would seem that a human right to subsistence confronts us with a problem: it is held to be a right, though the non-performance of its correlative duties does not constitute a wrong towards the holder of this right. ${ }^{47}$ This is problematic, however, for normally those duties that one can refrain from performing without wronging anyone are considered to be duties of virtue: "failure to fulfill them [i.e. duties of virtue] is not in itself culpability (demeritum) $=-\mathrm{a}$, but rather mere deficiency in moral worth $=0 .{ }^{\prime 48}$ Therefore it seems, thus far, that the duties correlative with the right to subsistence (as described by the institutional account) are, in fact, duties of virtue.

Still, those who view these imperfect duties as duties of justice could argue that the right to subsistence is in fact not held against particular individuals, but

44. Though certain authors have attempted to view imperfect duties as claimable prior to institutionalization: cf. Stemplowska. Real World Duties. 482. Yet, it is not clear how she expects to achieve true claimability on her account, which suggests that all indigents could simply have a claim to help from all those who have not yet undertaken sufficient steps to fulfill their duty.

45. Whereby duties of justice must be perfect, as imperfect duties of justice have been shown (in Chapter 2) to contain a contradiction of terms.

46. Anscombe, G. E. M. (2005). Who is Wronged? Philippa Foot on Double Effect: One Point. In M. Geach \& L. Gormally (Eds.), Human Life, Actions and Ethics. Essays by G.E.M. Anscombe (pp. 249-251). Exeter: Imprint Academic.

47. Notice how different this is from the duty to refrain from torture, for example. Here, if I do not fulfill my duty towards everyone, I most certainly do wrong others.

48. Kant. The Metaphysics of Morals. Ak 6:390. 
rather "against the vast group of agents who participate in these [unjust] social institutions." ${ }^{49}$ The right-holder thus has a right that the wealthy coordinate $a s$ a group to fulfill her right. This would do away with the argument based on human finitude, for conceivably if the wealthy would coordinate their relief and reform efforts they would in fact succeed in fulfilling subsistence rights for all. There would be no need for picking and choosing aid recipients (which leads to the suspicion that subsistence rights correlate with duties of virtue, as discussed above), because as a group they could fulfill the subsistence rights of all. But even if we grant that this is possible, the worry would be that rights held against an amorphous and anonymous group will de facto not be claimable. After all, without institutions the question remains where concretely one's claim can be lodged when one's right has not yet been fulfilled. The answer that the wealthy of the world as a group are responsible does not help us much: "Claimants who do not know who bears the counterpart obligations to rights they claim may grasp thin air." ${ }^{50}$ It seems this warning applies to the case of group duties as well. Placing the correlative duty on the shoulders of a collective may conceivably solve the problem of finitude, but it leaves the question "Who should do what for whom?" unanswered. Rights held against groups thus do not provide clear guidelines for individual agency.

Should we then conclude that our individual, institutional duties to the global poor are "merely" duties of virtue? They are, as we have argued, (1) indeterminate: which duty-bearers must perform which duties for which right-holder(s) remains unclear. As a consequence, they are (2) not claimable: if one does not know who owes what to whom, how is one to claim anything? Consequently, the duties to the poor appear to have (3) no correlative rights, since we understand having a right to mean one has a title to bind the freedom of another by claiming the performance of a certain duty from him or her. Given these three characteristics it seems we must conclude that our duties concerning global subsistence needs are duties of virtue. ${ }^{51}$

There remains, however, a crucial difference between our individual duties stemming from subsistence needs and traditional duties of virtue: the latter are not typically performed as recompense for an injustice for which one is (co)re-

49. Ashford. The Duties Imposed by the Human Right to Basic Necessities. 216.

50. O'Neill. Towards Justice and Virtue. 135. A similar critique of rights held against a group of duty-bearers collectively is put forward by Simon Hope: Hope. Subsistence Needs, Human Rights, and Imperfect Duties. 97.

51. Note that I leave out the fourth characteristic of duties of virtue mentioned above, namely that they are positive (whereas supposedly duties of justice can be only negative). I omit this point, because I hold that justice could also, given the adequate institutions, contain positive duties. 
sponsible. ${ }^{52}$ Regarding global poverty, however, I believe Pogge can be credited with convincingly demonstrating that, in fact, we are implicated in this injustice. If we accept this, then it seems unsatisfying to classify these duties as duties of virtue. Yet, judging them to be genuine duties of justice also seems inaccurate (as argued above). If we are to overcome this stalemate, we should recall that, at least according to the account I have provided, duties of justice are limited to those duties that correlate with a corresponding right to coerce others (to perform the duties in question).$^{53}$ Given that the duties in question are imperfect and therefore not claimable, it cannot be meaningfully held that these duties correlate with such a right. A human right to subsistence - whereby "right" must be understood as the ability to claim the performance of the correlative duty from the duty-bearer - thus becomes problematic. This could be viewed as an undesirable conclusion by proponents of this human right, but I would argue that we should not use certain words lightly: if we speak of a human right to subsistence, but the right-holder is unable to claim the performance of the corresponding duty from a specific duty-bearer, then one could wonder about the point of speaking of a right. If we speak of duties of justice, but it is utterly unclear what one ought to do for whom, then the meaning of "justice" has been altered to a point where it comes suspiciously close to virtue. The term "duty of justice" should add something that sets it apart from duties of virtue. As argued above, however, the structure of the institutional duties stemming from global subsistence needs is too similar to duties of virtue to be able to speak of duties of justice. If a duty is indeterminate and unclaimable it seems misleading to speak of duties of justice. This term creates expectations that, at present, can simply not be fulfilled. ${ }^{54}$

\section{Duties of a Remedial Nature}

Thus far we have dealt with situations in which subsistence rights are unfulfilled as a consequence of either direct or institutional harm. We have found that the duty to refrain from direct harm is a duty of justice, whereas the duty to refrain from institutional harm and the positive duties one incurs upon violation of this duty (i.e. the duties to provide aid and push for reform) are duties

52. Mieth, C. (2012). On Human Rights and the Strength of Corresponding Duties. In G. Ernst \& J-C. Heilinger (Eds.), The Philosophy of Human Rights (pp. 159-184). Berlin: Walter de Gruyter. 181.

53. Kant. The Metaphysics of Morals. Ak 6:383.

54. This is not to say that duties of aid, for example, could not become perfect duties of justice in a particular social scheme, such as a welfare state. In such a scheme individuals have clear duties of justice (to comply with the welfare system, to pay taxes) and right-holders have a justiciable right to subsistence goods. 
of virtue. What remains is to discuss the cases in which the lack of subsistence goods is either no one's fault (duty 1), or at least not my fault (duty 2.b), and remedial duties kick in. We will begin by discussing the former. Consider the plight of a country struck by an environmental disaster (e.g. a volcanic eruption or a tsunami), leaving countless inhabitants without secure access to food and shelter. Let us further stipulate that this environmental disaster did not occur as a consequence of climate change caused by man. In other words, this is not a matter of institutional harming: no one is to blame. At first glance, this situation might perhaps appear analogous to Singer's easy rescue case: we are not responsible for the trouble in which the child in the pond finds himself, but we are in a position to help and the rescue effort will not cost us any great effort or resources. Therefore, Singer concludes we have a duty to save the child. Similarly, the lack of subsistence goods in the afflicted country is not our doing, but if (the citizens of) wealthy countries work together they could, conceivably, alleviate the country's problems without too great a cost to themselves. This, however, is where the similarities end. In the easy rescue case it is clear who should do what for whom - I, the single passerby, should wade into the pond and save the child - rendering the duty in this example both perfect and possibly a duty of justice. In fact, several countries actually have such Good Samaritan laws, which include a duty to rescue. In the case of a natural disaster, by contrast, there are many possible candidates for the role of the Good Samaritan. Moreover, there could be various countries struck by natural disasters that are in need of our help..$^{55}$ Furthermore, we argued earlier on (in §4.1) that the duty to aid others in need (for which no one is to blame) allows for gradations of duty, by taking into account the special circumstances of the duty-bearer (is she able to help a lot or only a little, or perhaps not at all?) as well as the special relations between people and nations. The duty to assist in cases of a natural calamity is therefore underdetermined and unclaimable, hence imperfect. We must conclude, consequently, that the duty in question is a duty of virtue.

55. Much in Singer's account hinges on the analogy between the easy rescue case and the problem of global poverty. I have here raised one aspect of the problem of global poverty that renders that analogy problematic. Miller raises two further points against this analogy. Firstly, saving the drowning child is, most likely, a onetime event and will, for this reason, not interfere with our life plans in any significant way. Poverty, on the other hand, is a chronic problem. Secondly, in the easy rescue case the question who has caused the child's troubles is not raised (the child in the pond is simply an innocent victim), whereas in the case of global poverty it is of both moral and practical importance who is found responsible. Otherwise we will not be able to hold those accountable who have contributed to the poverty of others, nor will we obtain any insight into the question how we can prevent poverty in the future (Miller. National Responsibility and Global Justice. 234-7). 
This is not to say that we do not have strong moral reasons to aid those in need. We indeed have significant duties of virtue to help them. But, if we do not help them, or if we help others who are equally in need and deserving of our help, then we do not wrong them. ${ }^{56}$ For only if one has a right to the performance of a duty does its non-fulfillment constitute a wrong and thus a violation of justice. Furthermore, the imperfect duty to aid others who, through no one's fault, are in need of help can also become a perfect duty. Within a particular institutional scheme, the indigent can lodge their claim with a specified agency that assumes the duty of aid. All others in the scheme have the duty to cooperate with and contribute to this scheme. Thus when a fellow citizen, for example, has an accident, rendering her disabled and unable to work, the welfare state assumes the duty to ensure she is taken care of and has enough means to live her life. Indirectly, all the citizens share in this duty by complying with the welfare system and by paying taxes. In such a fashion an imperfect duty can be institutionalized and become a duty of justice. Somewhat analogously, countries could resolve to set up an international fund for disaster relief, under the supervision of the UN for instance, which could be relied on in cases of emergencies. ${ }^{57}$ In the case, however, where such an institutional structure is missing, individuals' duties to aid are imperfect in nature, and thus duties of virtue.

It is likely that not everyone will agree with this assessment. In National Responsibility and Global Justice, for example, David Miller holds that such remedial duties $d o$ fall within the purview of justice, though he does not provide an explicit argument for this position. Even more curious, he argues that such duties "must be discharged as a matter of justice, assuming that the relevant agent or agents are able to do so without infringing other, weightier, duties of justice." 58 On a Kantian account, however, the "permission to limit one maxim of duty by another" ${ }^{59}$ forms a clear indication that the duties at hand are imperfect and hence not duties of justice. By admitting that there may be weightier duties and that precedence ought to be given to such duties in a possible case of conflict, Miller himself in fact already describes the remedial duties to aid others after a (natural) disaster as duties of virtue. His insistence that they are nonetheless duties of justice therefore seems merely stipulative.

56. Though if we were to help no one at all, if we were to do nothing, then we would be in violation of our duty of virtue.

57. Perhaps we could imagine something along the lines of the UN's Green Climate Fund.

58. Miller. National Responsibility and Global Justice. 255.

59. Kant. The Metaphysics of Morals. Ak 6:390. 
Finally, consider the duty (duty 2.b) pertaining to the following situation: a large part of a particular country's GDP has the tendency to end up filling the large pockets of a small group of extremely wealthy and powerful oligarchs, who either reside within the upper echelons of the government or wield considerable influence on the administration's policy through their political clients. As a result, large portions of the people of this country find themselves in need of poverty relief. Obviously, primary responsibility for their indigence lies with the band of oligarchs. They, however, have no intention of leaving their fraudulent ways behind them. The question thus arises whether individuals of the world's wealthy nations have a duty of justice to assist those in need.

In addition to suffering from the same defects as the previously discussed remedial duty - i.e. being underdetermined and unclaimable, hence imperfect the duties in question are, as it were, "secondary." What I mean by this is that the duty to aid the inhabitants of this country originates in the failure of the primary duty-bearers. We are not to blame for the inhabitants' indigence and our duties to help them do thus not stem from an injustice we have perpetrated against them for which we now owe them recompense. Given that the primary responsibility lies with the small group of oligarchs, Miller is right that the secondary duty-bearers "cannot be required to act." "0 Accordingly, the oligarchs' refusal to fulfill their duty of justice to refrain from their harmful, fraudulent activities results in individuals elsewhere incurring not duties of justice, but rather duties of virtue to aid those in need.

By applying the conclusions of this section to Figure 1, we end up with the schema given in Figure 2. As this overview shows, we have found that in the absence of institutions to determine and allocate individual duties to the poor, most of these are best understood as duties of virtue. No doubt this result will be considered disappointing by those authors wishing to establish duties of justice to alleviate subsistence needs. However, I hope to have shown that if the concept "justice" is to be a fruitful concept, it ought to be clearly distinct from its partner concept "virtue." Accordingly, I have suggested that the realm of justice be limited to those rights and duties that fulfill the conditions of determinacy and claimability. If we were to abandon these prerequisites, then the important distinction between justice and virtue would be rendered obscure, resulting in "duties of justice" that are both indeterminate and unclaimable. What could be 


\begin{tabular}{|c|c|c|c|c|}
\hline Cause of poverty & Who has duties? & What duties? & $\begin{array}{l}\text { Basis for } \\
\text { according duties }\end{array}$ & Status of duties \\
\hline $\begin{array}{l}1 . \\
\text { Natural disaster } \\
\text { (no one is to } \\
\text { blame) }\end{array}$ & $\begin{array}{l}\text { All, but } \\
\text { gradations of } \\
\text { duty and ability } \\
\text { to help are taken } \\
\text { into account }\end{array}$ & $\begin{array}{l}\text { Positive duties } \\
\text { of aid }\end{array}$ & $\begin{array}{l}\text { Remedial } \\
\text { responsibility }\end{array}$ & Duties of virtue 61 \\
\hline \multirow[t]{2}{*}{$\begin{array}{l}2 . \\
\text { Direct harm }\end{array}$} & $\begin{array}{l}\text { a. } \\
\text { The agent that } \\
\text { has harmed }\end{array}$ & $\begin{array}{l}\text { a. } \\
\text { Negative duties } \\
\text { to refrain from } \\
\text { harming and } \\
\text { positive duties } \\
\text { to remedy }\end{array}$ & $\begin{array}{l}\text { a. } \\
\text { Outcome } \\
\text { responsibility }\end{array}$ & $\begin{array}{l}\text { a. } \\
\text { Duties of justice }\end{array}$ \\
\hline & $\begin{array}{l}\text { b. } \\
\text { All, but } \\
\text { gradations of } \\
\text { duty and ability } \\
\text { to help are taken } \\
\text { into account }\end{array}$ & $\begin{array}{l}\text { b. } \\
\text { Positive duties } \\
\text { of aid }\end{array}$ & $\begin{array}{l}\text { b. } \\
\text { Remedial } \\
\text { responsibility }\end{array}$ & $\begin{array}{l}\text { b. } \\
\text { Duties of virtue }\end{array}$ \\
\hline $\begin{array}{l}3 . \\
\text { (Global) } \\
\text { institutional } \\
\text { harm }\end{array}$ & $\begin{array}{l}\text { All those } \\
\text { participating in } \\
\text { the institutional } \\
\text { scheme }\end{array}$ & $\begin{array}{l}\text { Negative duty } \\
\text { to refrain from } \\
\text { participating in } \\
\text { unjust schemes, } \\
\text { and positive } \\
\text { duties to remedy } \\
\text { and reform }\end{array}$ & $\begin{array}{l}\text { Outcome } \\
\text { responsibility }\end{array}$ & Duties of virtue \\
\hline
\end{tabular}

Figure 2

the motivation for such an approach? Many authors wish to avoid what they view as the stigma of having the duties stemming from subsistence needs branded as duties of virtue, as they believe these to be of lesser importance than duties of justice. They therefore insist on classifying our duties to the poor as duties of justice in order to emphasize the fact that we truly have very strong reasons to fulfill certain duties to the poor. In doing so, however, they forget that duties of virtue provide us with strong moral reasons for certain courses of action as well. In fact, Chapter 2 refuted several arguments why perfect duties would be more important than imperfect duties or why duties of justice would carry a greater moral weight than duties of virtue.

61. It must be noted that those duties that are judged to be duties of virtue in this overview - with the likely exception of duty $2 . \mathrm{b}$ - are deemed so due to the absence of an institutional scheme that could allocate the duties in question. For example, all nations could conceivably contribute to an emergency fund, managed by the UN, to which funds they would have a right when disaster strikes their country. In this case all countries that commit to such a scheme would have a duty of justice to contribute to it. Similarly, the institutional duties in this schema could become duties of justice if, for example, there would be a global institution to clarify and allocate the duties of each. In the absence of such an institution, however, we 


\section{§ 4.3 - Do Subsistence Needs Give Rise to a Human Right to Subsistence?}

No doubt many human rights scholars and philosophers of human rights would disagree with the conclusion of the previous section that duties arising from global subsistence needs are duties of virtue (except for the duty to refrain from direct deprivation). They will, I expect, disagree more fervently when they realize that, on the account I have provided, the designation of these duties as duties of virtue also means that global subsistence needs do not give rise to a human right to an adequate standard of living (as only duties of justice can have correlative rights). After all, I understand having a right as the ability to claim the performance of the correlative duty from either specific or all duty-bearers.

Unwilling to accept this conclusion, critics of the position presented here could attempt several counterarguments. This section will discuss two such counterarguments. Firstly, they could hold that the position that global subsistence needs do not give rise to a human right to subsistence - whereas we do recognize, say, a human right not to be tortured - relies, at least in part, on a false dichotomy between civil-political rights and socio-economic rights, whereby the former are held to give rise to negative duties and the latter to positive duties. Secondly, they could argue that, like socio-economic rights, civil-political rights can also give rise to problems of claimability, forcing us either to give up claimability as a necessary trait of rights or to adopt the unattractive position that civil-political rights are, in certain circumstances, not claimable and therefore not truly rights either.

Let us begin with the first counterargument. Onora O'Neill's work is often targeted by those who put forward the first counterargument for maintaining too strict a division between civil-political rights (or "liberty rights" as she calls them) and subsistence rights. Liberty rights, she holds, are doubly universal: all have the right to freedom of movement, for example, which places duties on all others to refrain from impeding others to go where they choose. These duties can be easily performed by all for all, as they simply require forbearance. Subsistence rights, by contrast, require positive action on the part of others, e.g. to (help) provide a person in need with food, shelter or health care. Such duties, according to O'Neill, are therefore "enactable by all but not for all." Understandably, it is not possible for me alone to provide food for all those suffering from 
famine (whereas it is possible for me to respect everyone's right to freedom of movement). Consequently, the right to food "cannot be claimed by each from all." ${ }^{62}$ Rights to goods and services thus necessarily require institutions to distribute the duties among a great number of agents. Until such institutionalization has taken place, however, it is not possible to claim a right to food against any individual in particular. Absent institutionalization, the right does therefore not exist.

In Basic Rights, Henry Shue sets out to disprove the traditional distinction between liberty and subsistence rights, as found in the work of O’Neill, among others. Firstly, he argues, subsistence rights are more negative than they are often made out to be. The right to food for instance involves duties of forbearance as well: we all have a duty to not interfere with the food supply of others. ${ }^{63}$ Similarly, the right to health includes universal negative duties to refrain from actions that could damage the health of others. ${ }^{64}$ Secondly, and perhaps more importantly, Shue points out that negative rights are in fact far more positive than they appear to be. Article 6 of the ICCPR states, for example, that "[n]o one shall be actively deprived of his life." This might seem to involve solely negative duties of forbearance. Yet, the right to life, a classic liberty right, also requires a police force to help prevent violations of the right and to arrest violators. It requires, furthermore, a judicial system to try these violators, as well as prisons in which to incarcerate them. Finally, citizens will need to contribute to the creation and maintenance of these institutions through the taxes they pay. In brief, the enforcement of the right to life requires a great deal more than mere forbearance, and indeed involves quite some expenditure. In other words, it calls for positive duties. ${ }^{65}$ Shue concludes that the traditional idea that rights can be neatly divided between those that give rise solely to negative duties of forbearance and those that instead require solely positive duties of aid is "thoroughly misguided." In-

62. O'Neill. Towards Justice and Virtue. 148.

63. For an example of a case, in which a government has violated its negative duties to refrain from interfering with the food supply of a community, see: Inter-American Court of Human Rights, Case of the Yakye Axa Indigenous Community v. Paraguay. Judgment of June 17, 2005. Series C No 125.

64. For an example of a case, in which both a government and a corporation (the Nigerian National Petroleum Company, which is the majority shareholder in a consortium with Shell Petroleum Development Corporation) have violated their negative duties to refrain from any actions with grave, detrimental health impacts, see: African Commission on Human and Peoples' Rights, Ogoni People v. Nigeria. Judgment of May 27, 2002. ACHPR/COMM/A044/1.

65. A similar critique of the traditional position that negative rights require solely negative duties is provided by Jeremy Waldron: "The right not to be tortured generates a duty not to torture people, but it also generates a duty to investigate complaints of torture, a duty to pay one's share for the political and administrative setups that might be necessary to prevent torture, and so on" (Waldron. Liberal Rights. 25). Also see: Etinson, A. (2013). Human Rights, Claimability and the Uses of Abstraction. Utilitas, 
stead, all rights give rise to the same set of three duties, namely negative duties to avoid depriving, positive duties to protect from deprivation, and positive duties to aid the deprived. ${ }^{66}$ Therefore, if O’Neill maintains that subsistence rights are not claimable prior to an adequate allocation of the corresponding duties, she must also believe that traditional liberty rights, absent the allocation of the corresponding duties, are not claimable either. Given that liberty rights call for positive action as well, which cannot be enacted by all for all, they too are not to be considered proper rights until institutionalization has taken place. Surely O'Neill would wish to avoid such a conclusion. If so, it seems she must give up her position that the allocation of duties is an existence condition for rights.

This seemingly strong counterargument is, however, rather easy to refute. We need not disagree with Shue that rights of all sorts require institutionalization for their enforcement, yet this does not dispel the basic asymmetry between these rights. After all, "enforcement presupposes that the proper allocation of obligations has been identified. It is, after all, obligations, and not rights that will need enforcing." ${ }^{67}$ To illustrate: the protection of liberty rights will indeed, as shown above in the case of the right to life, require governments to take measures (to institute a police force, judicial body, prison system, and so forth), such that this right is adequately enforced. All these measures, however, rely on our prior understanding of what liberty rights require of whom, viz. all must practice non-interference in their interactions with all others. The normative relationship is thus already clear, and institutional measures are required solely to enforce it. Conversely, no such clarity is available in the case of subsistence rights. Such rights do not only require institutional measures to enforce an already clear normative relationship, but also rely on institutions to clarify who must do what for whom. The reason for this is that prior to institutionalization it remains unclear how the duties corresponding to such positive-action-requiring rights are distributed. It is only once such constructions (welfare systems, health care programs, social housing projects, etc.) are in place that we can fully know who owes what to whom regarding subsistence rights. The asymmetry between the two sorts of rights therefore remains. ${ }^{68}$

66. Shue. Basic Rights. 52.

67. O'Neill. Transnational Economic Justice. 135-6.

68. Alan Gewirth makes a related point when he argues that, though negative rights may require positive action for their enforcement, the ground for such positive action is itself still negative, namely "that potential offenders refrain from the prohibited actions" (Gewirth. Private Philanthropy and Positive Rights. 64). The distinction between negative and positive rights, he maintains, is thus still valid. 
Another way of putting the same point is that liberty rights are both genuine rights and independent moral norms that transcend their actual institutionalization. Conversely, subsistence rights, if they are to be genuine rights, must be made claimable within an institutional structure. The downside of this is that, as O'Neill does in fact conclude, subsistence rights are genuine rights only by virtue of convention; they are therefore not pre-institutionally existing rights, but rather special rights. Many scholars have taken issue with this position, arguing that the right to an adequate standard of living does exist prior to the allocation of duties. These authors consider the right to be a truly pre-institutional or natural right. However, the downside of this position is that the deontic implications remain fully indeterminate; who must do what for whom is left unsettled, leaving the right unclaimable (and therefore, according to O'Neill, not genuine). Therefore, O'Neill would conclude that in the case of the right to subsistence, it appears to be difficult to view the right both as a pre-institutionally valid right, and as a genuine, i.e. claimable, right with specific corresponding duties. In the end, however, O’Neill seems to wish to call subsistence rights neither special rights, nor universal rights simpliciter. Instead, she designates them "distributively universal special rights." ${ }^{69}$ They are special rights, because the performance of the correlative duty can be claimed only in virtue of a special, specified relationship with a particular duty-bearer (or particular duty-bearers). Yet they are also universal rights, because all may enter into such a special relationship. ${ }^{70}$

Elizabeth Ashford provides a second argument contesting the conclusion that subsistence needs give rise to duties of virtue and that, therefore, there is no human right to an adequate standard of living. The view that claimability is the existence condition of rights, she argues, will ultimately endanger the status of civil-political rights as genuine rights as well. Placing herself squarely in a Kantian tradition, O’Neill adopts precisely such a view: if it is not clear from whom I can claim the performance of the duties corresponding with my right (as is the case with subsistence rights, prior to allocation), then one cannot meaningfully hold that I possess the right in question. By discussing cases of additive harms, ${ }^{71}$ Ashford attempts to prove that O'Neill's condition for the existence of rights, i.e. claimability, is untenable. Ashford does not deny that in the case of subsistence 
rights it is often difficult to know who is responsible for providing the necessary aid. Rather, she maintains that often it is equally challenging to assign responsibility in cases of liberty rights violations. She makes use of Derek Parfit's example of "The Torturers' Union" to make her point. Fearing prosecution for human rights violations, the members of this union decide to arrange the torture in such a manner that the electric shock administered by each is spread out over a great number of victims, so that each of them contributes but a fraction of the total amount of harm caused to each prisoner. None of them thus cause (by himself) serious harm to any specific victim. By collaborating, however, the cumulative effect of their coordinated effort remains the same: a great deal of harm for all the victims, resulting in human rights violations.

This case may be somewhat out of the ordinary, Ashford concedes, yet it still presents us with a straightforward infringement of the right to be free from torture. Ashford maintains that for O'Neill, by contrast, it would be very difficult to view this as a violation of rights. If we imagine a situation, elaborating on the example of the Torturers' Union, in which it has become fully impossible to match specific victims to specific perpetrators, Ashford contends that O'Neill's claimability condition cannot be satisfied. At the same time, O'Neill must agree that the case of the Torturers' Union presents us with a grave violation of human rights. Therefore, Ashford concludes, “it is not plausible to claim [as O’Neill does] that serious harms can only count as human rights violations unless we can identify the agent or agents specifically responsible for any particular victim's suffering from such a harm."72

Taking a Poggean perspective on the principal cause of global poverty, it seems Ashford means to present the Torturers' Union as analogous to the problem of global poverty: a great many agents worldwide conspire to (knowingly or not) impose, uphold and profit from an unjust global order, predictably causing extensive violations of the human right to an adequate standard of living, without any particular agent being solely responsible for the harm suffered by any particular victim. If, Ashford maintains, the case of the Torturers' Union presents us with an apparent human rights violation, despite the impossibility of matching violators with victims, then the case of global poverty must likewise present us with an infraction of human rights, despite the impossibility of allocating responsibility in a precise fashion. 
Accordingly, Ashford deems the clarification and allocation of duties to be indeed "essential to the realization of human rights, but not [pace O'Neill] to their existence." ${ }^{\prime 3}$ Human rights do not come into existence at the moment their corresponding duties have been appropriately allocated. Rather, Ashford holds, it is far more plausible "that the right exists all along, founded on the universal status of human beings, and that it grounds the shared positive and negative duties that would realize the right." ${ }^{\prime 4}$ Ashford does thus not diminish the importance of allocating duties; she simply asserts that the question whether or not a right is claimable (and, if so, from whom) should be separated from the question whether or not the right in question exists.

Instead, O'Neill states that we cannot, prior to the allocation of duties, view subsistence rights as proper rights. Failing the institutionalization of subsistence rights, there is no sense in which a right-holder suffering from famine in Somalia can exert effective control over a specific duty-bearer, such that the former can ensure that the latter performs his duty. It is for this reason that O'Neill concludes that, unless the right-holders can identify the duty-bearers, "claims to have rights amount only to rhetoric: nothing can be claimed, waived or enforced if it is indeterminate where the claim should be lodged." 75

Concerning Ashford's claim that her examples of additive harms show that the distribution of responsibility in the case of liberty rights is equally unclear as it is in the case of subsistence rights: to this O'Neill could respond that she simply rejects Ashford's assumption that on O'Neill's account "each agent's responsibility for the human right violation is based ... on the harm that can be attributed to his own behavior in isolation" rather than "on the predictable overall impact of his behavior when conjoined with the behavior of the other agent." 76 She could argue that the only thing Ashford has shown is that when assigning responsibility for human rights violations, we must not merely view the conduct of individuals in isolation. Rather, we must also take into account the context in which they act, which will at times involve taking into account the role played by the actions of others. Take the gruesome practice of stoning a person to death. Each individual stone thrown will not likely be a lethal blow, but the cumulative effect of dozens of stones will do the job. There is nothing in O'Neill's account to prevent her from assigning responsibility in such a case. Participating in a prac- 
tice such as stoning is simply a violation of one's negative duty to refrain from harming, which we all owe towards all others. The same goes for participating in such a scheme as the Torturers' Union, which is set up with the clear intent to commit serious human rights violations, without the risk (or so the torturers hope) of being found guilty of such violations.

Furthermore, there is no clear analogy between the example of the Torturer's Union and the case of global poverty as we have discussed it under the heading of "(global) institutional harm." One does not make a clear decision to participate as a consumer and as a citizen of a wealthy country in the global politico-economic order with, moreover, the clear intent to contribute to the harming of others. By contrast, one does make a conscious decision to participate in the Torturers' Union's scheme, which, one imagines, one would only do if one were intent on inflicting harm on others.

Like Ashford, the interest theory of rights does not view claimability as an existence condition of rights either. Proponents of the interest theory could reject the conclusion that global subsistence needs do not give rise to a human right by arguing that all that is needed for the existence of a right is the duty-grounding nature of a particular interest that the right is meant to protect. On this view, the allocation of duties is thus certainly necessary for the fulfillment of rights, but it does not form the condition for the right's existence. Here, we could ask these critics if they realize the possible implications of rejecting claimability as existence condition of human rights. Most accounts of rights accept that by not performing a duty correlative to a right, one has not merely acted wrongfully, but one has also wronged the right-holder(s). By rejecting claimability, however, one in fact rejects the idea that a right-holder necessarily has a claim on those bearing the corresponding duties and, consequently, the idea that she is wronged when the duties corresponding to her right are not performed. For if she cannot claim the performance of the correlative duties, if she does not even know from whom she could claim such performance, in what sense can she then be wronged by their non-fulfillment? ${ }^{77}$ Who exactly has wronged her? We, therefore have good reason to doubt the tenability of an argument that is opposed to taking claimability as existence condition of rights, but that at the same time wishes to assert that the holder of a right is wronged when the correlative duty is not performed. 
At the end of the previous section we had concluded that the individual duties to fulfill subsistence needs are duties of virtue (except for the duty to refrain from directly causing a lack of subsistence goods). In this section, we considered two arguments against this conclusion, both of which were refuted. As a consequence, we cannot escape the further conclusion that global subsistence needs do not give rise to a human right to an adequate standard of living. This may be viewed as a defect or an undesirable aspect of what we called the "perspective of duties" (in Chapter 2). The perspective of duties, it was explained, starts from duties and proceeds to identify our rights. Instead, the more common perspective of rights starts by identifying rights independently of duties and from there proceeds to define the corresponding duties. One of the reasons for adopting the perspective of duties instead of the perspective of rights was that the latter can lead to unclaimable rights. By starting from the duties related to global subsistence needs, this chapter has been able to reveal the human right to an adequate standard of living as an unclaimable right.

The conclusion that this is not a genuine human right, however, may be seen by some to count as a defect of the perspective of duties. On the one hand, a right that cannot be claimed is indeed of little value. What would be the point of having such a "right" when it is unclear from whom one can claim the performance of the correlative duties? On the other hand, the claim of those who adopt the more common perspective of rights that the allocation of duties is certainly necessary for the realization of a right, but not for its existence, seems to resonate with certain intuitive normative judgments. To say that a starving child does not have a right to food, because she cannot lodge her claim with any specific duty-bearer, seems to amount to unnecessary hairsplitting. Furthermore, the proponents of the perspective of rights may argue that, though it is clear that the fulfillment of subsistence rights will require the allocation of duties, the reason why such rights need to be fulfilled in the first place remains unclear, from the perspective of duties. By contrast, "a rights approach can provide us with a justificatory basis for making 'perfect,' so to speak, our imperfect duties" by means of the allocation of duties. Such an approach "provides a moral argument for assigning these duties,"78 whereas such a moral argument seems more difficult from the perspective of duties. In the case of the malnourished child, for example, the rights-based argument is that she does have a right to food (given that it protects a fundamental human interest) and that, if corresponding duties 
have not been allocated, we are under a duty to set up a scheme that can realize such allocation, so that her right may be fulfilled.

Yet, those who adopt the perspective of duties could retort, as for example O'Neill does, that one need not assume the primacy of rights in order to provide a moral argument for the allocation of duties. O'Neill argues that justice requires rejecting, as non-universalizable, principles of action that predictably lead to injury (in this case, extremes of poverty and wealth, which create relations of domination, vulnerabilities and dependencies). ${ }^{79}$ In order to condemn certain actions or states of affairs no primacy of rights need be assumed. The moral argument for the creation of institutions that can allocate duties is thus as follows: in order to minimize the possibility of injurious (i.e. non-universalizable) action and remedy the occasions when such action does occur, institutions will need to be created in order to define and assign the relevant rights and duties. Being defined and allocated within a specific institutional context, however, these rights are, strictly speaking, not universal human rights, but rather special rights that take shape within a particular institutional structure. O'Neill argues that these subsistence rights may be distributively universal: they cannot give rise to universal duties as, say, the right to be free from torture can, but the correlative special duties can be distributed in such a way that the claims of all right-holders are covered.$^{80}$

Though the perspective of duties and the perspective of rights judge the status of subsistence rights and their correlative duties differently, they both believe the creation of institutions to provide the most adequate means to ensure no one is deprived of necessary subsistence goods. The only difference is that proponents of the latter position consider the right to precede the allocation of duties through institutionalization, whereas the former regard institutionalization as a necessary condition for the right's existence. If we are to retain the view that having a right consists in exercising control over another (that is, in being able to claim the performance of the correlative duty from another), then we must conclude that in the absence of allocating institutions there is no human right to subsistence. If having a right is to mean more than a moral appeal to unknown others, we need to stick to the idea that possessing a right requires the ability to claim the performance of duties from identifiable others. If we are to avoid the admittedly unsatisfactory conclusion that fulfilling global subsistence needs is, therefore, a matter not of justice but rather of virtue, then we must endeavor to embed the corresponding duties in an institutional setting. 


\section{§ 4.4 - Conclusion: The Mutual Dependence of Just Institutions and Virtue}

The previous chapter ( $\$ 3.1$ specifically) provided a brief overview of the treatment of our duties arising from global subsistence needs in human rights documents. We found that the duties of states have been clarified quite well, but that the elucidation of individual duties is still in much need of further research. Human duties declarations that arose as a reaction to the lack of attention for individual duties in human rights documents, were no great help either. In order to provide some clarity, therefore, the present chapter set out to investigate the current philosophical debate on global subsistence needs and their correlative individual duties. Hereby it was our explicit intention to present - by means of an examination of these individual duties of aid - a demonstration of one of the advantages of the perspective of duties, namely its greater ability to distinguish between genuine and inauthentic rights. Accordingly, we structured this chapter around three questions: (1) Who has what duties in fulfilling subsistence needs?, (2) What is the status of our duties concerning the fulfillment of subsistence needs?, and (3) Do subsistence needs give rise to a human right to subsistence?

Regarding the first question, $\$ 4.1$ provided an overview of all the possible individual duties concerning the fulfillment of subsistence needs (see Figure 1). We distinguished three separate causes of the non-fulfillment of subsistence needs, which trigger either remedial or outcome responsibility resulting in either negative or positive duties (or both). Next, the need arose to clarify the status of these duties. This task was undertaken in \$4.2. Basing ourselves on the exposition of duties provided in Chapter 2, the duties springing from subsistence needs were deemed imperfect and therefore duties of virtue, save for the duty to refrain from directly depriving others of their means of subsistence.

Finally, §4.3 considered two possible counterarguments against the conclusion that our duties to the global poor are duties of virtue, in order to retain the possibility of viewing subsistence rights as genuine human rights. Both these arguments were refuted, however, rendering inescapable the conclusion that global subsistence needs do not give rise to a human right to subsistence. Given the definition of a right developed in Chapter 2, according to which having a right should be understood as the ability to claim the performance of the correlative duty from a specific duty-bearer (or specific duty-bearers), I conclude that in the present condition, that is, in the absence of allocating institutions, the right to subsistence is not a genuine human right.

This conclusion should lead neither to the belief that therefore our duties to the global poor are not important, nor that these duties of virtue cannot become 
duties of justice. Regarding the latter point, we could say that our conclusion that under present circumstances these duties are duties of virtue underlines the importance of the creation of institutions and legislation that can specify and allocate these duties, perhaps eventually rendering them duties of justice. Miller, too, views the creation of certain global institutions that can distribute our sundry duties to fulfill the subsistence needs of the global poor as the only way in which what he terms the "justice gap" ${ }^{81}$ can be narrowed, even if it can perhaps not be entirely filled. Indeed, the importance of allocating institutions is underwritten by those involved in human rights practice as well. They argue that a good way to guarantee subsistence rights is by enshrining the right to food, for example, in the country's constitution. ${ }^{82}$ An even better solution, however, is to draft so-called framework legislation ${ }^{83}$ on the right to food. As the UN's Food and Agriculture Organization states:

A framework law on the right to food can give a precise definition of the scope and content of this human right, set out obligations for state authorities and private actors, establish necessary institutional mechanisms and give the legal basis for subsidiary legislation and other necessary measures to be taken by the competent state authorities. ${ }^{84}$

The necessity to render duties perfect by implementing national or international legislation is thus clearly recognized. The hope is that by embedding subsistence rights, such as the right to food, within an institutional and legal setting, their fulfillment will be guaranteed.

No institutional scheme or set of laws is perfect, however. There will always be cases that slip through the cracks. Even institutional schemes that are largely

81. The justice gap is the "gap between what people in poor countries can legitimately claim as a matter of justice ... and what the citizens of rich countries are obliged, as a matter of justice, to sacrifice to fulfil these claims" (Miller. National Responsibility and Global Justice. 274). Similarly, Feinberg emphasizes the importance of allocation in the case of so-called Good Samaritan duties: "Positive duties to rescue are every bit as serious as negative duties not to harm. Unlike the latter, however, they must be divided into parts, allocated in shares, and (often) executed by appropriate specialists" (Feinberg, J. (1984). The Moral and Legal Responsibility of the Bad Samaritan. Criminal Justice Ethics, 3(1), 56-69. 68).

82. The right to food is present in the constitutions of, inter alia, South Africa (Article 27(1)), Kenya (Article 43(1)) and Brazil (Article 7(IV)).

83. Framework legislation lays down rather general principles and duties concerning, in this case, the right to food, which can subsequently be further defined by additional legislation issued by the relevant (national or international) authorities.

84. Bojic Bultrini. Guide on Legislating for the Right to Food. 4. Cf. De Schutter, O. (2010). Countries Tackling Hunger with a Right to Food Approach: Briefing note 1. UN Special Rapporteur on the Right to Food. 13: "National parliaments should be encouraged to work towards the adoption of framework laws that establish a participatory mechanism aimed at the adoption of a national strategy for the realization of the right to food." 
just and generally complied with will not be able to completely prevent cases of unfulfilled rights. It is herein that the importance of duties of virtue lies: when there are no institutions to allocate duties and ensure their performance (as is the case, I have argued, with our current duties to the global poor), or such institutions do not function flawlessly (which will, most likely, always be the case), duties of virtue function as a necessary and indispensable complement to the sphere of justice. Our duties of virtue include, among others, duties to help those who, as said, slip through the cracks and duties to push for reform of the prevailing institutions so that fewer cracks remain.

The fact that such duties are most adequately described as duties of virtue - as such political engagement, if it is to be meaningful, will require a considerable amount of time and effort, forcing one to exercise discretion in choosing the causes to which one dedicates these resources - does not mean that they are any less important. It is only from the perspective of rights that duties that do not stem from rights are dismissed as "mere" duties of virtue, as if it were another term for "supererogatory acts." From the perspective of rights, duties to aid the poor do not exist if they do not stem from rights. For this reason, proponents of this perspective must obstinately insist that duties to aid the global poor are duties of justice which stem from human rights to have subsistence needs met. The very idea that we could have important duties to aid the poor that are not duties of justice stemming from human rights is dismissed out of hand. By instead adopting the perspective of duties, we can recognize such duties and their importance as well as provide a greater clarity with regard to both our duties and our rights.

The creation of and compliance with just institutions, i.e. justice, is not enough. It is, to say the least, doubtable that the liberal dream of just institutions without virtuous people, can be realized. Virtue therefore remains necessary. The drafters of the UDHR, incidentally, recognized this, which is why, I argued in the previous chapter, they adopted Article 29(1): "Everyone has duties to the community in which alone the free and full development of his personality is possible." The following chapter will continue in this vein by providing an account of the function and importance of civic duties and civic virtue. 



\section{CHAPTER 5 - DUTIES TO THE COMMUNITY AND CIVIC VIRTUE}

Die Pflicht ist insofern nicht Beschränkung der Freiheit, sondern nur der Abstraktion derselben, das heißt der Unfreiheit: sie ist das Gelangen zum Wesen, das Gewinnen der affirmativen Freiheit. ${ }^{1}$

Perché così come gli buoni costumi per mantenersi hanno bisogno delle leggi, così le leggi per osservarsi hanno bisogno de’ buoni costumi. $^{2}$

The discussion in Chapter 3 (Section 3.2) has already shed considerable light on our duties to the community. We distinguished three different categories of such duties: civic duties of justice (such as the duty to obey the law and to pay taxes), sacrifices demanded for the common good (such as the various duties of civic participation), and the duty to perform one's duties from the motive of duty, which requires civic virtue. It was, furthermore, established that, save for the first category, these duties are best placed in the realm of virtue. Finally, it was determined that the community to which these duties are owed is best understood as the (national) political community, for which reason we may also refer to duties to the community as "civic duties."

Still, as became clear in Chapter 1, duties to the community are far from uncontroversial. The "sacrifices demanded for the common good" (regarding which I will mostly focus on the duties of civic participation) and the duty to perform one's duty from a particular disposition are especially contentious. ${ }^{3}$ The present chapter will, therefore, only be concerned with these two sets of duties. It will provide an instrumental argument for (1) the necessity (and the good) of civic duties (particularly those of civic participation), and (2) for the importance of the cultivation of civic virtue (necessary for the willing performance of one's

1. Hegel, G. W. F. (1986). Grundlinien der Philosophie des Rechts oder Naturrecht und Staatswissenschaft im Grundrisse. Frankfurt am Main: Suhrkamp Verlag. \$149 Zusatz.

2. Machiavelli, N. (2013). Discorsi sopra la prima deca di Tito Livio. Milan: Bur Rizzoli. Libro primo. XVIII. 109.

3. This is not to say that the duty to obey the law has not led to an enormous debate on political obligation. Yet, in general, the duty to obey the law of one's country is less controversial than the duty, say, of political participation (by voting, attending neighborhood assemblies, etc.) and the duty to perform both of these duties from the motive of duty. This also became apparent from our discussion of the human duties declarations in Chapter 1: duties to serve the community and calls for a global ethic were criticized especially vehemently. 
duties, that is, from the motive of duty) as well as maintain that it is (3) imperative that the state take an active role in the promotion of both.

Parallel to the discussion between the proponents and the critics of the human duties declarations, and roughly in the same period (more or less the past two decades $^{4}$ ), we have witnessed a lively debate within political philosophy between liberals and republicans. Most importantly for our purposes, the republican theorists have argued, firstly, for a renewed focus on our (civic) duties and, secondly, for the necessity to not concentrate on just laws and institutions alone (as many liberals do), but to also pay attention to the disposition of citizens: the state ought to cultivate in them "the disposition to give public ends precedence over private desires in both political action and deliberation," 5 that is, the state ought to stimulate the development of civic virtue. The present chapter will discuss these two points (respectively in \$5.1 and in §5.2) and will therefore be structured as follows: Section 5.1 will set out the importance of a renewed emphasis on civic duties. In brief, in $\$ 5.1 .1$ a renewed emphasis on duties will be found necessary for two reasons: firstly, it is to lead to the stimulation of a different, more active understanding of citizenship and, secondly, the performance of civic duties plays a crucial role in the preservation of our rights. This justification for promoting civic duties is, furthermore, purely instrumental in nature, thus maintaining its distance to the approach presented by intrinsic republicans, who would promote civic duties because they retain them to be an integral part of the good life.

Subsequently, in $\$ 5.1 .2$, it will be shown that specifically duties of civic participation are beneficial to both the political community as a whole and the individual citizens within it. Four such beneficial functions of civic participation will be presented, following a discussion of John Stuart Mill's discussion of the good of civic participation.

The second point often put forward by republican scholars - that concerning the necessity of the cultivation of civic virtue - will be discussed in \$5.2. The argument will be made that our rights and freedom are more secure when

4. Though of course the revival of republicanism within the field of historical scholarship (due chiefly to the works of J.G.A. Pocock and Quentin Skinner) dates back to the late seventies of the past century.

5. Burtt, S. (1990). The Good Citizen's Psyche: On the Psychology of Civic Virtue. Polity, 23(1), 23-38. 35-6. The equation of civic virtue with a settled disposition to work towards the common good instead of one's own particular interests has been a trait of republican thought since its earliest beginnings, and it remains a central tenet of the work of republican scholars today: see e.g. Aristotle. (1944). Politics. (H. Rackham, Trans.). Cambridge (Mass): Harvard University Press. 1279a18-1279a33; Cicero. On Obligations. I 85; Montesquieu, C. de. (1989). The Spirit of the Laws. (A. M. Cohler, B. C. Miller, \& H. S. Stone, Eds. \& Trans.). Cambridge: Cambridge University Press. Bk. IV, Ch. V; Rousseau. The Social Contract. Bk. I, Ch. 7 [7]; Skinner, Q. (1986). The Paradoxes of Political Liberty. The Tanner Lectures on Human Values, VII, 225-250. 242, 182; Maynor, J. W. (2003). Republicanism in the Modern World. Cambridge: Polity Press. 182. 
civic virtue is widespread. When, by contrast, civic virtue is by and large absent, the state will need to take recourse to either the coercion or the enticement of its citizens, that is, by appealing to citizens' self-interest. Such a political community, devoid of civic virtue, is doomed to remain unstable, as the majority of its citizenry will withdraw its compliance with the laws once such compliance ceases to be in their interest. Consequently, the conclusion will be that the state may legitimately take measures to cultivate civic virtue. In order to reach this conclusion, \$5.2.1 will first provide a critique of a particularly strict, yet quite common version of liberal neutrality, which compels the state to remain neutral on all matters of virtue and thus forbids the state from taking any measures to foster it. Subsequently, §5.2.2 makes the point that the cultivation of virtue by the state is legitimate on the strict condition that the state limits itself to the promotion of civic (not personal) virtue and refrains from the imposition of a comprehensive doctrine. Finally, §5.2.3 will present three legitimate means of promoting such civic virtue.

In the conclusion, finally, I will suggest that this chapter as a whole has demonstrated the interdependence of the two realms of morality: justice and virtue. Specifically, this chapter will render apparent the great importance of duties of virtue for the preservation of just institutions and the protection of individual rights and freedom. In doing so, it will belie the common assumption that duties of virtue are of little importance.

\section{§ 5.1 - An Instrumental Argument for Civic Duties: A Rebuttal of Two Coun- terarguments}

In Chapter 1 we saw that the drafters of the various human duties declarations provided a number of reasons for a renewed focus on our duties. They argued, for example, that especially Western liberal democracies overemphasize individual rights and personal liberty, to the detriment of our duties to the community and an understanding of freedom as involving necessarily a sense of responsibility. This imbalance between rights and duties, between freedom and responsibility, results, they concluded, in an unbridled individualism which could lead to conflict and discord. The effective and reliable protection and realization of human rights, furthermore, relies on all of us performing our duties. Therefore, rather than weakening or endangering human rights, a renewed emphasis on our duties would only strengthen human rights. 
Republican scholars provide very similar arguments for a renewed emphasis on duties. Individuals who "would enjoy the rights of a citizen without being willing to fulfill the duties of a subject" commit an "injustice, the progress of which would cause the ruin of the body politic."6 It is this fear, expressed here by Rousseau, for an understanding of freedom as license, for a view of the individual as detached from the community and for an insistence on absolute rights uncoupled from duties, that has contributed to the popularity of the republican position and has led people to doubt the desirability of (certain aspects of) the liberal political model. The overwhelmingly negative response to the human duties declarations, however, indicates how a large number of people still views duties as inhibitions to their freedom, rather than as an expression of as well as a necessary condition for their freedom, indicating the strong lasting influence of a particular current of liberal thought. In order to better understand this negative reaction we must consider its intellectual roots. Accordingly, in the first subsection, I will provide a brief sketch of this specific strain of liberalism, which absolutizes freedom and rights at the cost of duties. This position will be shown to run into two problems: firstly, it leads to a passive and detached understanding of citizenship and, secondly, it actually leads to the endangerment of our rights.

Subsequently, in the second subsection, I will discuss an argument directed specifically against duties of civic participation. Joseph Schumpeter's theory of democracy, known as competitive elitism, will hereby be treated as an exemplary rejection of more participatory theories of democracy that greatly value duties of civic participation. Following the exposition of Schumpeter's argument, a case for the instrumental importance of duties of civic participation will be made. Such duties will be presented as beneficial to both the political community as a whole and the individual citizens within it.

\section{\$5.1.1 - Two Problems with Limitless Freedom}

The current of liberal thought responsible for the apprehension over civic duties we found in the reaction of human rights scholars to the human duties declarations can be traced back to the work of Thomas Hobbes and his understanding of freedom (or liberty ${ }^{7}$ ), which has proven quite influential. Hobbes viewed lib- 
erty as finding "no stop, in doing what [one] has the will, desire, or inclination to doe." Accordingly, liberty depends on the "Silence of the Law" and is best understood as "Immunitie from the service of the Commonwealth." ${ }^{10}$ For Hobbes, freedom thus consists in the absence of restrictions, which clearly include civic duties ("service of the Commonwealth").

Over a century and a half later, Benjamin Constant would name this understanding of liberty "liberty of the moderns." Whereas the liberty of the ancients consisted chiefly in the positive liberty to participate in the governing of the republic, the liberty of the moderns is mainly negative. Not unlike Isaiah Berlin's later definition of negative liberty, Constant understood the liberty of the moderns as freedom from interference by the state, which was to be secured by a set of rights. He argued that ancient liberty required too great a sacrifice of citizens - as self-governance calls for regular attendance of assembly meetings in order to actively participate in political debates and the voting process - who no longer view political freedom, but rather individual independence as their primary need. For the ancients, liberty still meant the "sharing of social power among the citizens of the same fatherland." By contrast, the "aim of the moderns is the enjoyment of security in private pleasures; and they call liberty the guarantees accorded by institutions to these pleasures." Accordingly, "one must never require from them [the moderns] any sacrifices to establish political liberty. It follows that none of the numerous and too highly praised institutions which in the ancient republics hindered individual liberty is any longer admissible in the modern times." 12 It is by being steeped in this liberal tradition that critics of the human duties declarations seem to view duties automatically as restrictions to freedom, or as providing "governments with excuses to limit the exercise of human rights, ${ }^{13}$ as if rights and duties were necessarily mutually exclusive rather than complementary. From such a point of view, duties of active citizenship must simply be rejected as a hindrance to individual liberty.

Another century and a half later, Ronald Dworkin would introduce the idea of individual rights as political trumps. He argued that if someone has a right to

8. Ibid. Ch. 21, 146 .

9. Ibid. Ch. 21, 152.

10. Ibid. Ch. 21, 149. Note how this understanding of freedom views freedom and the performance of civic duties as mutually exclusive.

11. Constant, B. (1988). The Liberty of Ancients Compared with that of Moderns. In B. Fontana (Ed. \& Trans.), Political Writings (pp. 307-328). Cambridge: Cambridge University Press. 317. Emphasis added.

12. Ibid. 321.

13. Knox. Horizontal Human Rights Law. 3. 
have or do something, "then it is wrong for government to deny it to him even though it would be in the general interest to do so." 14 Rights would thus generally prevail over considerations of the common good or the general welfare. In fact, for Dworkin, it seems any weighing of rights against the rights of others or considerations of the common good is tantamount to their abrogation. ${ }^{15}$ This liberal position, which views rights as nearly absolute, has received substantial criticism from those who argue instead for the necessity to "take duties seriously.” For example, one can hear an echo of Rousseau's words cited above in Mary Ann Glendon's rejection of "rights talk:" "in its [i.e. rights talk's] silence concerning responsibilities, it seems to condone acceptance of the benefits of living in a democratic social welfare state, without accepting the corresponding personal and civic obligations." 16 The argument is that rights uncoupled from duties stimulate a perverse kind of freedom understood as doing whatever one wishes, of which republicans have always spoken disparagingly. Aristotle, for example, rejected the idea of freedom as doing as one pleases, ${ }^{17}$ and he would have rejected the conception of freedom prevalent in modern liberal democracies today, which views freedom simply as being left alone within one's own private sphere, as not being forced to do anything one does not want to, including serving the community. ${ }^{18}$ The Hobbesian strand of liberalism discussed here attempts to expand this private sphere as far as possible, the "eventual aim being to achieve what Isaiah Berlin has called 'a maximum degree of non-interference compatible with the minimum demands of social life'." ${ }^{19}$ Duties to the community are therefore but unwelcome obstacles to the unimpeded realization of limitless liberty or viewed as potentially perilous restrictions of rights. The predominance of this current of liberalism in human rights circles can, as said, be deduced from the nearly unanimous rejection of "duties to the community" in scholarly commentaries on human duties declarations and on certain human rights documents such as the African Charter. It is, therefore, this variety of liberalism that must be contested.

14. Dworkin. Taking Rights Seriously. 269. Cf. xi and 169. Also see: Dworkin, R. (2011). Justice for Hedgehogs. Cambridge, Mass: Belknap Press of Harvard University Press. 329

15. Dworkin. Taking Rights Seriously. 198ff.

16. Glendon, M. A. (1991). Rights Talk: The Impoverishment of Political Discourse. New York: The Free Press. 14

17. Aristotle. Politics. 1310a28-1310a33. Similar rejections of freedom as license can be found throughout the republican tradition. See, e.g., Cicero (On Obligations. I. 70) and Rousseau (Rousseau, J.-J. (1984). A Discourse on Inequality. (M. Cranston, Trans., M. Cranston, Ed.). London: Penguin Books. 58: "they mistake for liberty an unbridled license which is the opposite of freedom").

18. Kraut, R. (2002). Aristotle: Political Philosophy. Oxford: Oxford University Press. 208.

19. Skinner. The Paradoxes of Political Liberty. 248. 
To be clear, it is by no means my intention to say that the protection, by means of rights, of personal liberty has not been an enormous achievement. On the contrary, the knowledge to be secure in one's rights is a great good. The problem does not lie in the effort to secure rights; it lies, rather, in the one-sided understanding of the relationship between rights and duties, according to which duties are merely undesirable limitations of our rights and should therefore be kept at a bare minimum. This unbalanced view, in fact, has two negative consequences. Firstly, by paying attention solely to what we as citizens stand to receive from the community (in the form of rights), that is, what the community must do for us, we are left with a passive and detached understanding of citizenship: passive, because citizens will tend to view the essence of their citizenship simply as the possession of rights, ${ }^{20}$ and detached because such a one-sided understanding of citizenship leads to the image of the lone rights-bearer over against everyone else (recall our discussion of the Marxist critique of $18^{\text {th }}$ century human rights declarations in \$3.2.2). By focusing exceedingly on individual rights, and by being suspicious of any duties to the community, we are encouraged to think of ourselves as separate from the community, which in turn increasingly appears as a threat to the private enjoyment of our rights, rather than as the necessary condition for the development of our personality. ${ }^{21}$ The renewed emphasis on duties is meant to remedy this understanding of passive and detached citizenship and wishes to complement (not replace) the image of the citizen as the holder of certain rights with the view of citizenship as involving the performance of civic duties. When rights and duties are more in balance, the idea of rights as trumps will also be adjusted. Rights will not (and ought not to) always enjoy precedence over any claims the community makes on us. ${ }^{22}$

The second undesirable consequence of the lopsided understanding of the relation between rights and duties is that the diminished interest in our civic duties actually endangers the reliable protection and realization of our rights. For certain civic duties it is not difficult to imagine how their performance contributes to the security of our rights, for instance the civic duty to obey the law and the duty to pay taxes (and thus contribute to the maintenance of the shared social welfare system). Yet, it may be less evident how other civic duties contrib-

20. Kymlicka. Contemporary Political Philosophy. 288.

21. As, for example, Article 29(1) UDHR suggests by stating that one's personality can only be fully developed within a community.

22. In fact, we have seen already (in §1.3.1) that not all human rights are absolute and that our exercise of these rights is limited by public safety, the protection of health and morals, the rights of others, and so forth. 
ute to the protection of our rights, for example the duties of civic participation. Generally, civic participation is meant to indicate those actions, performed by citizens, which aim to contribute to the addressing or resolution of matters that are not merely private concerns, but rather concerns common to all members of a community. Civic participation is thus participation, in some way, in public affairs. One can hereby think of a variety of duties, such as the duties of political participation, ${ }^{23}$ to be informed about current affairs, and to address patent injustices (by writing to your representatives, starting or supporting a petition, organizing or participating in a protest). These duties contribute to the protection of our rights in the following manner: the protection and fulfillment of rights depend on the rule of law, good legislation and democratic institutions. The mentioned duties that fall under the heading of "civic participation" help uphold these three key elements. For example, an active citizenry can function as a check on overambitious and corrupt politicians by calling them to account (by voting them out of office, raising awareness about their ties to big business, or organizing demonstrations against them). A greater participation of citizens in the democratic process (on a municipal, national or regional level) would, furthermore, help improve legislation, as politicians would be made more aware of the needs of the public.

It follows that even if one views rights as primary to or more important than duties, one should still applaud a renewed emphasis on the latter. By shirking one's duties, convinced that they are but limits to one's rights and unbound freedom, one thus in fact imperils those very rights and that very freedom one holds so dear. Rather than a threat to our rights, we ought to therefore view a renewed emphasis on our duties to the community as contributing to the safeguarding of those very rights: "unless we place our duties before our rights, we must expect to find our rights themselves undermined." ${ }^{24}$

We have thus found that a renewed emphasis on duties is necessary for (1) stimulating a different, more active understanding of citizenship and (2) for the preservation of our rights. We may add, as this will be of importance in

23. This can take many forms; one can participate politically by voting, attending neighborhood assemblies, joining a political party, running for office, and so forth.

24. Skinner. The Paradoxes of Political Liberty. 250. Cf. 248-9. Also see Viroli, M. (1988). Jean-Jacques Rousseau and the "Well-Ordered Society." (D. Hanson, Trans.). Cambridge: Cambridge University Press. 184-5. A similar argument is offered in some of the human duties declarations. The DHSR, for example, maintains that the "rights of the individual and his or her social responsibilities are indissolubly linked. They mutually reinforce each other and for that reason deserve express recognition of their equal value and importance to life in society" (Article 5). Far from radical or dangerous, therefore, the renewed focus on our duties is in fact meant to benefit the protection and realization of our rights. 
what follows, that our reasons for advocating civic duties are therefore solely instrumental; such duties are not promoted, in other words, because their performance is viewed as an integral part of the good life. Even the stimulation of a different understanding of citizenship is done because of its importance for the stability of the political order, and not because it is deemed intrinsically valuable. Yet, despite this instrumental importance of civic duties, some still challenge their necessity. In what follows, one such argument against the necessity of civic duties (specifically, duties of civic participation) is laid out. Certain, elitist theories of democracy do not only question the necessity of duties of civic participation, they also argue that too much citizen participation can actually constitute a threat to the political community.

\section{\$5.1.2 - The Good of Civic Participation vs. Competitive Elitism}

In this subsection, I mean to establish the instrumental importance of the performance of duties of civic participation, both for the development of the individual citizen and for the health of the political community as a whole. Eventually, four beneficial functions of the performance of such duties will be presented. In arriving at these four functions, a discussion of John Stuart Mill's understanding of civic participation as a "school of public spirit" will play a crucial role.

Before making the case for duties of civic participation, however, let us consider a counterargument. There are those who would argue against such civic duties by maintaining that the role of the citizen consists solely in producing a government through elections. Joseph Schumpeter, for example, criticized what he termed "classical democracy" and the many civic duties it demanded of its citizenry. According to Schumpeter, classical democracy (unrealistically) presupposes a citizenry well informed on a wide range of topics and able to formulate an own position with regard to these sundry issues. Subsequently, citizens elect representatives to execute that position. Schumpeter held this view to be overly optimistic with regard to the intellectual abilities of the average citizen as well as vis-à-vis the electorate's desire to actively participate in the business of government. ${ }^{25}$ Citizens are neither able nor have any desire to participate in the drafting of policy or to otherwise participate politically. Rather, democracy simply boils down to the election of leaders who will then do the deciding for us. It is but a 
method, "an institutional arrangement of arriving at political decisions in which individuals acquire the power to decide by means of competitive struggle for the people's vote." 26 Schumpeter thus maintains a strict division of labor: once citizens have voted into office a government, they are from that point onward to refrain from any form of participation. Even the writing of letters to your representatives is to be banned. ${ }^{27}$

Significantly, Schumpeter often draws an analogy between the businessman and the politician. Just as in the market place various competitors vie for the favor of the consumer whose role is merely to choose between various alternatives, so too democracy can be described as a "free competition for a free vote," ${ }^{28}$ whereby the citizen is viewed as a passive consumer. According to this so-called "economic theory of democracy," the prudent citizen, like the sensible consumer, will choose that representative who is most likely to further the citizen's particular interests (as opposed to the common good). Government thus ends up consisting of an incongruous collection of representatives, each representing a particular interest (group). Any policy that would ensue, could therefore not be an expression of the general will, aimed at the common good, but is rather merely an articulation of what Rousseau termed the "will of all," i.e. "nothing but a sum of particular wills." ${ }^{29}$ Given such an understanding of government and the view of citizens as consumers striving to further their own interests as best as possible, all that rests for the government to do, is the aggregation of competing interests. Richard Dagger rightfully wonders how such interest-aggregation could ever generate allegiance when the resulting policy happens to clash with my particular interests, for " $[\mathrm{w}]$ here self-interest does not dictate obeying the law, there is simply no reason to obey." ${ }^{30}$ As a consequence, the state will come to rely heavily on coercion, as motives other than the desire to evade punishment are not available to a theory of democracy and citizenship "that regards the public as a loose collection of atomistic individuals and politics [following Schumpeter's economic analogy] as simply another way to advance or defend one's personal interests." 31 Indeed, if one rejects (as Schumpeter does) the ideas of a general will and the common good, ${ }^{32}$ and one strives to exclude as far as possible the citizenry from the task of governing, it becomes exceedingly

26. Ibid. 269.

27. Ibid. 295.

28. Ibid. 271.

29. Rousseau. The Social Contract.. Bk. II, Ch. 3 [2].

30. Dagger. Civic Virtues. 107.

31. Ibid. 105.

32. Schumpeter. Capitalism, Socialism and Democracy. 251. 
difficult to view the government and its laws as anything other than external obstacles to the realization of the citizen's own interests, to be bypassed and undermined whenever possible.

One sign of the prevalence of the above described theory of democracy and citizenship - a sign, that is, that citizen participation is not considered (neither by the government, nor by the citizens themselves, it seems) a necessary ingredient for a healthy democracy, nor as an integral element of democratic citizenship - is the relatively low percentage of citizens who bother to make the trip to the polling station. Only a little over half of the voting age population showed up for the most recent elections in the Netherlands. ${ }^{33}$ The last parliamentary elections in the United Kingdom (in 2010) saw a voter turnout of less than two thirds of the eligible voters $(65.77 \%)$. In the United States, elections for Congress, when they coincide with the presidential elections, have seen a voter turnout of roughly $66 \%$ since the beginning of this century, whereas less than half of eligible Americans have voted in the last three midterm elections. France, finally, saw a mere $55.4 \%$ of its eligible voters show up for the last parliamentary elections in 2012. ${ }^{34}$

But why do such low numbers constitute a problem? What is wrong with political apathy (which involves more than merely staying away from the polls)? Alternatively (to rephrase the same question in a positive fashion), what are the advantages of citizen participation in the democratic process? Some would argue that such apathy is in fact unproblematic, for several reasons. ${ }^{35}$ First, as Schumpeter holds, more participatory accounts of democracy attribute "an altogether unrealistic degree of initiative" to citizens. ${ }^{36}$ If people fail to participate (by voting, attending neighborhood meetings, or joining a political party) they apparently do not attach much value to political participation. Politics does not play a large role in their life and they prefer to spend their time in a different manner. If in a particular election certain interests of theirs are at stake, then perhaps they will make the way to the polls, but otherwise (in keeping with the citizen-as-consumer view) they do not see how it will benefit them. Second, one could argue that as long as a certain amount of voters shows up (though how many exactly are needed, is difficult to say), the electoral process will not crumble. Therefore political apathy, so long as it does not spread to all citizens, does not pose a threat.

33. According to the Dutch online database Kiesraad, only 54\% of the eligible voters actually voted for the 2014 municipal elections and less than half of the eligible voters (47.76\%) participated in the 2015 provincial elections. The database can be consulted at: www.verkiezingsuitslagen.nl.flie

34. These data can be found at the online database of the International Institute for Democracy and Electoral Assistance (IDEA): http://www.idea.int/vt/.

35. Here I draw from Richard Dagger's work: Dagger. Civic Virtues. 133-4.

36. Schumpeter. Capitalism, Socialism and Democracy. 270. 
Third, elite theories of democracy such as Schumpeter's go one step further by arguing not only that political apathy is harmless but that, moreover, it is desirable. The basis for this position is a very low estimation of citizens' knowledge of current events. If citizens are to participate in politics in any way, we must first assume that they have thoroughly informed themselves of the myriad issues and formed an independent position regarding these questions. Their political will must thus be "something more than an indeterminate bundle of vague impulses loosely playing about given slogans and mistaken impressions." ${ }^{37}$ Elitist theorists of democracy are at best skeptical that the average citizen is capable of such subtle political reasoning and consequently fear that a greater influence of citizens on the political process would result in the rise to power of populists and demagogues. Therefore, political apathy amongst the uninformed masses is hardly something to be lamented.

Despite these seemingly strong arguments against civic participation, I will argue, largely in keeping with the theory of democracy known as developmental democracy, that in fact political participation by the citizenry is "necessary not only for the protection of individual interests, but also for the creation of an informed, committed and developing citizenry. Political involvement is essential to the 'highest and harmonious' expansion of individual capacities." ${ }^{38}$ Four beneficial functions of the performance of duties of civic participation will be presented, belying the position (discussed above) that the performance of such civic duties is unnecessary for the health of the political community or even detrimental to it. Hereby particular attention will be given to Mill's understanding of civic participation as a "school of public spirit."

Republicans of all stripes would agree that democratic practice fosters certain capabilities and character traits, though opinions may differ as to why this is of such importance. For example, one could find that the cultivation of certain capacities and dispositions is essential to the realization of the good life (in an Aristotelian sense), which is judged to lie in the life of the active citizen. Alternatively, one might argue that the development of citizens' capacities and the promotion of civic virtue are necessary for the maintenance of a country's democratic institutions and for the preservation of our rights. The former position is often referred to as intrinsic republicanism, whereas the latter is termed instru- 
mental republicanism. ${ }^{39}$ In what follows, an instrumental argument in favor of duties of civic participation will be presented. In doing so, Mill's Considerations on Representative Government will prove a helpful guide.

Mill begins the third chapter of this work by discussing the possibility of a good despotic monarchy. For the sake of argument, he is willing to grant the possibility of an all-seeing, thoroughly informed and hardworking monarch disposing over merely honest and talented civil servants (picked out by himself; after all, the sovereign also has a keen eye for talent). Yet, even if we were, for the sake of argument, to grant all this, we must still ask ourselves "[w]hat sort of human beings can be formed under such a regimen? What development can either their thinking or their active faculties attain under it?"40 Thus, apparently, the question of how to organize a government is also a question of the "sort of human beings" we wish to form by means of the particular organization of government we decide upon. Absolute power, even when wielded by a benevolent lord, inevitably results in an utterly passive citizenry, Mill maintains, in evident disapproval. The wish is, therefore, to set up a form of government that will bring forth active citizens instead.

Given that Mill argues that only some form of participation in public affairs can bring about the intellectual and moral development he has in mind, and given that democracy alone renders possible such participation for all (as opposed to, for example, the absolute monarchy discussed above, or a form of aristocracy in which only the "best" participate), he concludes that only a democracy will be able to produce active citizens. Ideally - Mill here refers to ancient Athens -, there would be a complete and personal participation of all in government. Yet, since all cannot, in our large modern nation states, participate fully in the conducting of the affairs of state, we must content ourselves with a representative democracy. ${ }^{41}$

Nevertheless, even a representative government provides us with plenty of opportunities to perform some small public functions. Mill mentions jury duty,

39. These terms are employed by, e.g., Sandel (Sandel, M. J. (1996). Democracy's Discontent: America in Search of a Public Philosophy. Cambridge (Mass): Belknap Press of Harvard University Press. 26) and Peterson (Peterson, A. (2011). Civic Republicanism and Civic Education: The Education of Citizens. New York: Palgrave Macmillan). Others scholars prefer the pairs Aristotelian-instrumental republicanism (Kymlicka. Contemporary Political Philosophy. 294), civic humanism-classic republicanism (Rawls, J. (2005). Political Liberalism (Expanded Ed.). New York: Columbia University Press. 205-6), Aristotelian-Roman republicanism (Burtt. The Good Citizen's Psyche.) or virtues as ends-virtues as means (Galston, W. A. (1988). Liberal Virtues. The American Political Science Review, 82(4), 1277-1290. 1279-81).

40. Mill, J. S. (2008). Considerations on Representative Government. In J. Gray (Ed.), On Liberty and Other Essays (pp. 203-467). New York: Oxford University Press. 239.

41. Ibid. 256. 
but we could also think of participatory policy making, attending neighborhood meetings, and taking part in referenda and elections. Mill aptly notes that, for the most of us, our work places and private lives do not encourage us to take into consideration the greater common good. It is the performance of civic duties such as those mentioned above that places us outside of our limited personal sphere and "introduces the mind to thoughts or feelings extending beyond individuals." ${ }^{\prime 2}$ Any kind of participation in public affairs, however small, encourages us to take into consideration the interests of others, to make decisions based not on our personal preferences but on what is best for the common good. Civic participation forms a "school of public spirit," which causes one "to feel himself one of the public, and whatever is for their benefit to be for his benefit." Instead, if one never performs civic duties, and remains encapsulated always within one's private sphere, one never manages to think "of any collective interest, of any object to be pursued jointly with others, but only in competition with them, and in some measure at their expense." $" 3$

Two closely related functions of civic participation can already be distilled from this brief discussion of Mill. First, such participation has an educative function $^{44}$ (the "school of public spirit"). One learns how to, in Rousseau's terms, make the transition from a mere "man" guided solely by private interests, to a "citizen" who acts in accordance with the general will and takes the common interest into consideration. ${ }^{45}$ In other words, one develops, through the performance of duties of civic participation, civic virtue. This is, as it were, a moral education. Second, this education stimulates the citizen to view herself as part of a larger whole; it imbues her with a feeling of belonging to the community. This is called the integrative function. Ank Michels adds a third function of civic participation by arguing that it ensures good government. Participation by citizens results in legislation that better takes into account the common interests of all, instead of the private interests of the influential few.

I would include a fourth function of civic participation, which we could call the emancipative function of civic participation. The idea is that a greater participation in public affairs will result in a greater knowledge of one's rights vis-à-vis one's government as well as one's fellow citizens. Furthermore, for those who

44. For a treatment of the first three functions of civic participation mentioned here, see e.g. Michels, A. (2006). Citizen Participation and Democracy in the Netherlands. Democratization, 13(2), 323-339. 
regularly participate, the threshold to stand up and fight for these rights when infringed, will be far lower than for those who have never found the way to public forums: "the rights and interests of every or any person are only secure from being disregarded when the person interested is himself able, and habitually disposed, to stand up for them." ${ }^{\prime 6}$

It has thus become apparent how civic participation can have a positive influence on both the citizens and the state in which they live. Civic participation leads to (1) the creation of true citizens (in the Rousseauian sense) who take into consideration the rights of others as well as the common good of the community at large, of which they (2) consider themselves an integral part. It is plain that the community at large should benefit from an abundance of such citizens. Yet, we have seen that civic participation is also beneficial for the citizens themselves. Participation brings a degree of influence, which in turn could (3) lead to better (or at least more representative) legislation. Lastly, their participation brings citizens knowledge of the workings of government, their rights and their duties, making them (4) more assertive.$^{47}$ Therefore, contrary to certain theories of democracy (such as Schumpeter's) that deny the importance of civic participation, we have presented four beneficial effects of the performance of such duties, both for the individual citizen and for the political community as a whole.

In closing I note once more that the argument in favor of duties of civic participation is an instrumental one: the regular performance of such duties has beneficial effects both for the citizens themselves and for the political community at large. A possible intrinsic value of such performance is therefore emphatically not taken into account.

\section{$\S 5.2$ - The Importance of Civic Virtue}

Where the previous section focused on the second category of civic duties (of the three we distinguished in Chapter 3) - that is, civic duties demanded for the common good, especially duties of civic participation -, the present section will

46. Mill. Considerations on Representative Government. 245.

47. Recent empirical research has also demonstrated that civic participation has these beneficial effects. Ank Michels, for example, concludes on the basis of her empirical research on the effects of four different types of civic participation, whereby she took into consideration 120 cases from different Western countries, that civic participation has positive effects on, inter alia, citizens' skills and virtues, their ability to influence government and on the legitimacy of legislation and policy: Michels, A. (2011). Innovations in Democratic Governance: How Does Citizen Participation Contribute to a Better Democracy? International Review of Administrative Sciences, 77(2), 275-293. 
center on the third category of civic duties - that is, the duty to perform one's duties from the correct motive, namely from the settled disposition to give precedence to the common good over one's own personal interests. It is this settled disposition we have in mind when we speak of civic virtue.

The call, in some form, for civic virtue is common to many human duties declarations. Many commentators have taken issue with such appeals for a "global ethic" or for the stimulation of "voluntary self-obligation," as they fear it will encourage states' paternalistic tendencies. No longer would states limit themselves to the prescription and enforcement of rules regulating our external conduct. Now they could also concern themselves with our motives for acting; states will judge not only whether or not we have wronged (i.e. violated the rights of) others, but also whether or not we are good. Thus, Pavlos Eleftheriadis, in a paper in which he assesses a proposal for a new "British Bill of Rights and Responsibilities" issued by the UK government, worries that the enjoyment of rights will be considered conditional on one's civic virtue: "Failure to exhibit civic virtue in your own motives may result in the loss of the remedy that would normally entail your right." 48

In this section I wish to provide an argument for the importance of the cultivation of civic virtue by the state that can avoid such pitfalls. My intention hereby is not to provide a defense of the various human duties declarations themselves or those who drafted them, but instead to demonstrate the importance of widespread civic virtue for the stability of a political community as well as show that the state may take certain measures to cultivate civic virtue and still respect important liberal principles such as respect for individual rights and freedoms as well as liberal state neutrality (although an overly strict understanding of liberal neutrality will be shown to be untenable, in Subsection 5.2.1).

As has become clear from the discussion of Mill's work on representative government, the task of government ought not to be limited to the prescription of rules alone. After all, any law can be broken or abused and so long as there is no civic virtue in place there are no guarantees for widespread compliance, the absence of which brings with it a threat not only to the rights and liberties of all, but also to the democratic order as such. Therefore, if the laws of the land are to be reliably followed, government must also concern itself with the business of character formation: "No constitution will ever be good and solid unless the law rules the citizens' hearts. So long as the legislative force does not reach that 
deep, the laws will invariably be evaded." ${ }^{\prime 9}$ In other words, the reliable performance by all citizens of the civic duty to obey the law (an example of the first type of civic duties we distinguished, namely the civic duties of justice) hinges on widespread civic virtue (crucial to the third type of civic duties, i.e. performing one's duties from the motive of duty). Furthermore, as argued in the previous section, the performance of the second type of civic duties (chief among which are the various duties of civic participation) is key to the formation of civic virtue. Put more succinctly, the civic duties of justice to obey the law and respect the rights of others depend on widespread civic virtue, the fostering of which in turn depends on the performance of duties of civic participation. ${ }^{50}$

That good laws and political institutions alone do not suffice, but must be supplemented by civic virtue, has been a common theme of republican writers throughout the centuries. Thus, in the Discorsi Machiavelli maintains that when "custom is corrupted, good legislation is of no avail." "Corruption," for Machiavelli, is a technical term; a citizen is corrupt when she ignores the calls of the common good whenever the good of the community conflicts with her own private interests. $^{52}$ Machiavelli is therefore making the argument that a system of laws, however good they may be, will not suffice to protect citizens against arbitrary interference by others if most people in the state do not possess a settled disposition to obey the law, for citizens could be tempted to break the law if they had good reason to believe it would be in their best interest. A political community could be in possession of the most just system of taxation and redistribution imaginable, yet if the majority of the citizens is lacking in civic virtue, that system will inevitably fall prey to free riders and to the affluent segment of the political community exploiting loopholes in the tax code whenever they have reason to believe it will be in their own best interest not to contribute.

Furthermore, the widespread presence of civic virtue in a political community also provides more of a guarantee that our politicians legislate not to further their own good, but rather to promote the good of the community as a whole. Finally, we spoke earlier of how the performance of civic duties may cultivate civic virtue. We can also imagine, however, that once civic virtue has taken root

49. Rousseau, J.-J. (1997). Considerations on the Government of Poland and on its Projected Reformation. In V. Gourevitch (Ed. \& Trans.), The Social Contract and Other Later Political Writings (pp. 177-260). Cambridge: Cambridge University Press. OC (Oeuvres Complètes) III, 953. Emphasis added.

50. Though there are other sources of civic virtue as well, such as public education and the laws and institutions themselves, which will be discussed later on.

51. Machiavelli, N. (1970). The Discourses. (Leslie J. Walker, Trans.). New York: Penguin Books. Bk. 1, Ch. 17.

52. See, e.g., ibid. Bk. 1, Ch. 18. 
we will be more motivated to continue participating in democratic institutions, thus strengthening and vitalizing them. In brief, the widespread presence of civic virtue, firstly, renders our rights and freedom more secure from arbitrary interference. Furthermore, it preserves our laws and political institutions by, secondly, warding off their self-interested manipulation as well as by, thirdly, encouraging participation. It is for these reasons that "republican laws must be supported by habits of civic virtue or good citizenship." 53

Yet, how can such civic virtue be cultivated by the state, while at the same time respecting the principle of state neutrality? The eventual answer will be that a strict version of neutrality cannot be maintained, as will be argued in $\$ 5.2 .1$. If state neutrality does not allow government to take any steps in cultivating virtue, it is unable to produce the attitudes and dispositions needed for the stability of the political community. For when civic virtue is entirely absent, the state will have to rely heavily on coercion or the enticement of the citizens' private interests. Certainly, a democratic order will not be stable if the majority of its citizenry will withdraw its compliance with the laws once such compliance ceases to be in their interest. ${ }^{54}$ The necessity of character formation by the state is thus evident and the strict understanding of liberal neutrality - barring the state from such character formation and instead limiting the scope of legitimate state action to the setting up of the basic structure and the drafting of laws must therefore be rejected.

At the same time, however, any time statecraft involves "soulcraft" we must be fully aware of the risks involved. The forming of character and the influencing of our dispositions have often been the pastime of tyrants. It is therefore of the utmost importance to distance any acceptable case for the cultivation of civic virtue from such nefarious precedents. This dissociation will be undertaken by means of the treatment of two questions, each of which will be discussed in its own subsection: (1) To what extent is the moral character of citizens of the state's

53. Pettit, P. (1997). Republicanism: A Theory of Freedom and Government. Oxford: Oxford University Press. 245.

54. Indeed, this intuition is confirmed by studies in the field of social sciences, concerned with compliance with legal norms, such as Tom R. Tyler's classic Why People Obey the Law. He distinguishes instrumental reasons for complying with the law, which amount to a weighing of the probability that one will be punished if one does not comply, from normative commitments. These, in turn, can be divided between personal morality (obeying the law, because one considers it just) and legitimacy (obeying the law, because one retains that the law enforcing authority has the right to prescribe actions). Tyler's research clearly points out that relying on coercive measures alone (and thus solely on instrumental reasons) is not at all conducive to the stability of a state. His findings are backed up by an entire body of existing research indicating "that in democratic societies the legal system cannot function if it can influence people only by manipulating rewards and costs:" Tyler, T. R. (2006). Why People Obey the Law. Princeton: Princeton University Press. 22. Such societies are, furthermore, under constant threat of instability. 
concern? In other words, when is it legitimate for the state to concern itself with its citizens' virtue? (2) In what manner may the state cultivate such virtue? Subsection 5.2.2, while discussing the first of these two questions, will maintain that the state may take measures to promote civic virtue, but must refrain from interfering with citizens' personal virtue by imposing a comprehensive moral or religious doctrine. In this sense, an important form of state neutrality is maintained - as the state remains neutral with regard to comprehensive doctrines -, even though strict liberal neutrality - barring the state from any involvement with its citizens' virtue - is rejected. Finally, §5.2.3 will answer the second question by presenting three legitimate ways for the state to cultivate civic virtue.

\section{$\S$ 5.2.1 - The Problem of Strict Liberal Neutrality}

A very early account of the neutral state can be found in the work of Kant. The division of The Metaphysics of Morals into a doctrine of right and a doctrine of virtue is instructive on this point: whereas the latter instructs us to strive after our own moral and intellectual perfection and to promote the happiness of others, the former makes the argument that the sphere of right - and therefore the sphere of politics - ought not to concern itself with personal virtue or the happiness of others (lest it become paternalistic ${ }^{55}$ ), but must instead be restricted to "the concept of freedom in the external relation of people to one another." 56 Politics must be limited to the protection of the right of each; it may only ensure "the restriction of each individual's freedom so that it harmonizes with the freedom of everyone else;" 57 it must categorically refrain from any interference with matters of the citizens' good. This position of state neutrality has proved extremely influential in the further history of liberalism. And indeed the critique of human rights advocates on certain aspects of the human duties declarations is reminiscent of Kant's position: they maintain that a document aspiring to the same quasi-juridical status as the Universal Declaration ${ }^{58}$ has no business calling for the creation of a global ethic, since "voluntary self-obligation" is a matter of

55. Paternalism can roughly be understood as the idea that the state ought to take measures to improve the happiness, welfare or interests of its citizens, as it views its citizens as unable to make the right decision for themselves. A paternalistic state thus literally views itself as a father who needs to care for and educate his unmündige children. This is roughly how Jonathan Quong defines his "judgmental definition" of paternalism: Quong, J. (2011). Liberalism Without Perfection. Oxford: Oxford University Press. 80.

56. Kant. Theory and Practice. Ak 8:289.

57. Ibid. Ak 8:289-90.

58. As is the case for both the UDHRe and the DHSR. 
free self-constraint and thus of virtue. The sphere of justice is limited to the protection of the rights and the freedom of each. These limits are at the same time the boundaries of legitimate state action and of legitimate legislation.

Similarly, in formulating his famous "harm principle," Mill excludes one's good (either physical, intellectual or moral) from legitimate reasons for interfering with citizens' liberty of action. Only the prevention of harm is a valid reason for compelling another. Whether or not the performance or omission of particular actions will make her happier or a better person can, therefore, never be a reason for compelling her to act in certain ways rather than others. ${ }^{59}$ More recently, this common tenet of liberalism figures prominently in the work of Rawls. He argues that freedom may only ever be limited for the sake of freedom itself, never for the promotion of some good (be it economic benefits or some interpretation of human excellence).$^{60}$ The fostering of civic virtue through the imposition of certain duties of civic participation, for example, does therefore not fall within the purview of justice and is consequently not a valid objective for government to pursue. Indeed, the principle of liberal neutrality dictates that the government is to refrain from imposing or even promoting any particular comprehensive theory of the good life, including that of the good citizen.

At the same time, however, even liberals who extol the value of liberal neutrality recognize the importance of civic virtue. Thus, later on (in §5.2.2) we will see how Rawls recognized the importance of virtue for the political stability of a community. Yet, such liberal scholars do not seem to allow for any means of virtue promotion, except for the wholesome influence of living under just laws and institutions (which will be further discussed in \$5.2.3). Thus, the old charge of a paradox inherent to liberalism returns: "because they [i.e. strict liberals] require 'neutrality' by government among competing conceptions of the good life, they bar government from cultivating the civic virtue upon which a stable political order depends." ${ }^{1}$ There is no place in the work of many liberals for an active role of the state in encouraging the formation of virtue - not even civic virtue - as this would endanger the state's neutrality in their eyes. Let us consider the work of Rawls to explore the consequences of this position.

Rawls's understanding of moral psychology supposes that when people live under laws and institutions they recognize to be just, they will be more disposed

61. Fleming, J. E., \& McClain, L. C. (2013). Ordered Liberty. Cambridge (Mass): Harvard University Press. 81. 
to do their part in maintaining those laws and institutions. When we, furthermore, witness others doing their part in maintaining these arrangements "with evident intention," we develop trust in them, which, in turn, brings about a stronger bond with both them and with the just arrangements we cooperate in maintaining: "Thus if those engaged in a system of social cooperation regularly act with evident intention to uphold its just (or fair) rules, bonds of friendship and mutual trust tend to develop among them, thereby holding them ever more securely to the scheme." ${ }^{\prime 2}$ Rawls supposes, moreover, that these bonds of friendship and mutual trust will grow stronger as the just laws and institutions are successfully maintained over time. The strength of these bonds, finally, leads to the formation of the "cooperative virtues," such as "justice and fairness, fidelity and trust, integrity and impartiality," ${ }^{63}$ without which a liberal political community would succumb to instability.

As ingenious as Rawls's account of the development of what we have been calling "civic virtue" is, it suffers from one considerable defect, namely it supposes ideal circumstances: virtue develops when institutions are just, which all willingly cooperate in maintaining, and which remain stable over time. In non-ideal circumstances, however, many citizens cooperate merely for prudential reasons (e.g., because they fear punishment or because, for the moment, it benefits their private interests) and do no more than is legally required of them, institutions are not entirely just, and the political community suffers from instability. It is fair to say that in such circumstances the source of virtue, as Rawls (and many others liberals) understands it, is absent or at least dysfunctional. Consequently, on this liberal account, the (non-ideal) society that needs civic virtue most is also the least able to foster it. Thus, if we accept the view that the only permissible way for a state to engender virtue is through the good influence of its institutions, "then in hard times, when public life in a liberal state becomes stagnant or rancorous, civil society lethargic, and the family embattled, the state would be obliged to sit idly by and watch helplessly from the sidelines as the wellsprings of the virtues necessary for order and liberty slowly evaporated." 64

It thus seems that Rawls's position runs into problems once we move from virtue formation in ideal circumstances to non-ideal circumstances. Yet, this is not just a problem for Rawls. Indeed, it is a commonplace claim of contemporary 
liberal theory that justice is limited to setting up basic structures; the possibility that the state may (and indeed must) also concern itself with (the promotion of) civic virtue is thereby excluded. The reason contemporary liberals often provide for the exclusive focus on the basic structure of society - namely that it profoundly influences the life plans of citizens - is true enough, but so is the statement that a just basic structure relies on civic virtue for its stability. By denying the validity of this latter point, it would seem that many contemporary liberals cherish the hope that "good laws will work without good men or women," 65 a hope which, I suggest, is in vain.

To recap: an overly strict version of liberal state neutrality - compelling the state to remain neutral on all matters of virtue and thus forbidding the state from taking measures to foster civic virtue - is untenable as it is unable to produce the attitudes and dispositions on which the stability of the political community depends. By restricting government action to the setting up of the basic structure and the drafting of laws, Rawlsian liberals have effectively deprived themselves of the necessary tools to ensure stability in non-ideal circumstances. Given this serious problem with strict liberal neutrality, the necessity for the state to concern itself with its citizens' virtue has become apparent. Yet, it still remains for us to clarify when such cultivation of virtue by the state is legitimate and when it is not. This question will be answered next.

\section{\$5.2.2 - When Is It Legitimate for the State to Concern Itself with Its Citizens' Virtue?}

In brief, the answer this subsection will provide is as follows: So long as the state's goal in cultivating civic virtue is not the imposition of a particular conception of the good life (the intrinsic republican position), but rather the safeguarding of the stability of the political community as well as the rights and freedom of those who dwell within and without ${ }^{66}$ it (the instrumental republican position), it is legitimate for the state to concern itself with its citizens' virtue. This position is, furthermore, compatible with a less strict understanding of liberal

65. O'Neill, O. (1990). The Great Maxims of Justice and Charity. In Constructions of Reason: Explorations of Kant's Practical Philosophy (pp. 219-233). Cambridge: Cambridge University Press. 220: "Plato had hoped that good men would need no laws; deontological liberals hope that good laws will work without good men or women."

66. Indeed, the beneficial effects of civic virtue are not limited to the state of which one is a citizen. We will return to this matter in the conclusion of this dissertation. 
state neutrality: the state is to remain neutral with respect to comprehensive doctrines, but may take measures to foster civic virtue, which is of public concern.

One of the fathers of modern liberalism, Immanuel Kant, warns against a government that would wish "to make the people happy in accordance with [its] concepts" and labels such sovereign power despotic. ${ }^{67}$ This helps us to answer our first question as to when it is not legitimate for a state to take an interest in the cultivation of the virtue of its citizens. Intrinsic republicanism would argue that, given that man is a social and political animal, participation in public life is the quintessential good life, thus equating being a virtuous person with being a virtuous citizen. On this account, the state encourages civic participation and fosters civic virtue in order to help its citizenry achieve the good life. In this manner, intrinsic republicanism wishes to impose what Rawls would have called a "comprehensive doctrine." It first posits wherein the full development of human beings lies and subsequently structures its political institutions, drafts its laws and encourages its citizenry in such a way as to help all its citizens realize this definition of a fully accomplished human life. Thus the very first sentences of Aristotle's Politics, a work often viewed as an example of intrinsic republicanism, make the point that the state is a partnership that is founded (like all partnerships) for the realization of some good, which he later seems to equate with the active life of the citizen. ${ }^{68}$ In modern pluralistic societies, however, one cannot assume any widespread agreement about what constitutes the good life. When a state, therefore, promotes civic virtue because it believes it to be conducive to the achievement of human flourishing, such promotion constitutes an illegitimate imposition of a particular comprehensive moral doctrine on the citizenry. Such a state would indeed be attempting to make its citizens happy according to its own understanding of happiness and may rightfully be denounced as paternalistic. ${ }^{69}$

67. Kant. Theory and Practice. Ak 8:302.

68. Though there is some evidence that Aristotle takes this position (e.g. Aristotle. Politics. 1325a33), Aristotle also often speaks of the good life in more general terms, namely as human flourishing (eudaimonia), which he defines as a "life conjoined with virtue furnished with sufficient means for taking part in virtuous action" (ibid. 1323b40-1324a1). If the good life is read in the latter, more general sense, one could also understand Aristotle to be saying that the state is a partnership founded for the realization of the good life for all, however individual citizens may understand that life.

69. Another case of illegitimate state concern for citizens' virtue would be the imposition of a particular religion: the state would, for example, make it its concern to prevent its citizens from having sex before they are married, to force women to dress in a certain manner and to make sure that all actively participate in and contribute to the religious services. Apostasy would, of course, be outlawed and all must live in accordance with particular religious dietary laws. The state is here not concerned with creating good citizens; rather, it wishes to create good men and women, as defined by the state religion. It does not 
By contrast, one could also make an instrumental argument for the cultivation of civic virtue by the state. The point would then no longer be that the state promotes civic virtue in order to help realize the state-sponsored version of the good life for all, but rather that civic virtue is necessary for the preservation of our freedom and our political community. Thus, a state may encourage civic virtue - that is, it may encourage us to be good citizens -, but it may not encourage personal virtue - i.e., it may not strive to make us good men and women: ${ }^{70}$ “attempts to encourage 'good morals' or to compel actions dictated by . . . moral standards must be confined to norms of civil morality; they cannot properly extend to norms of good behavior predicated upon controversial 'comprehensive' moral and religious beliefs." ${ }^{\prime 11}$ Herein lies the answer to our question: if the goal in cultivating civic virtue lies in the strengthening of the political community, it is quite acceptable, but if the goal is to impose a particular conception of the good life, then it is illegitimate and must be rejected.

Concrete examples of instrumental arguments for civic virtue can be found in some of the human duties declarations. The drafters of the UDHRe, for example, considered what Hans Küng termed "voluntary self-obligation" the document's main aim. ${ }^{72}$ The drafters believed such voluntary self-obligation to be crucial for the effective realization of human rights, which cannot depend on legal coercion alone, but must instead be able to rely on citizens binding themselves through ethical incentives (as opposed to the legal incentive of coercion). In a similar fashion, the drafters of the DHSR called for the development of a global ethic, which was meant to strengthen international human rights law. ${ }^{73}$ The drafters of both documents were convinced that legal rights alone are not able to secure a rightful condition and that therefore the rights discourse must be supplemented by a concern for the development of citizens' dispositions. The call for civic virtue, common to these two documents, is thus argued for instrumentally.

Quite surprisingly, therefore, many human rights advocates nonetheless denounced these declarations as paternalistic. It was, among other things, the call

restrict itself to the cultivation of civil morality, needed to maintain a stable democratic order; instead, it imposes a comprehensive religious doctrine in order to make its people good in accordance with its concept of goodness. Such a state would indeed be, as Kant said, despotic.

70. It is Aristotle who poses the question whether good citizens must also be good men. In the end, he concludes that not all citizens need be good men, which once more belies the common reproach that Aristotle is an intrinsic republican: Aristotle. Politics. 1276b16-1277a6.

71. Spragens, T. A. (2004). Legislating Morality in Liberal Democracies. In A. Etzioni, A. Volmert, \& E. Rothschild (Eds.), The Communitarian Reader: Beyond the Essentials (pp. 55-60). Oxford: Rowman and Littlefield Publishers. 56.

72. Küng. Human Responsibilities Reinforce Human Rights. 168.

73. UNCHR. Human Rights and Human Responsibilities. 20. 
for a global ethic that was deemed dangerous, as critics feared that states would abuse this call by imposing a particular mode of conduct they deem "moral." These critics fear, in other words, that states may start to show perfectionist tendencies, whereby perfectionism can be understood as the idea that states should play an active part in promoting the good life. Yet, at times, even the great thinker of strict liberal neutrality, John Rawls, recognized the necessity for a democratic state to concern itself with the cultivation of what he called "political virtues." Though Rawls's account of justice as fairness remains neutral in important respects and strives for overlapping consensus, it does recognize the importance of certain political virtues for the simple reason that these virtues describe "the ideal of a good citizen of a democratic state." 74 These virtues are the virtues of fair social cooperation, which include the virtues of civility, tolerance, reasonableness (or spirit of compromise) and a sense of fairness. Rawls supposes that political and social cooperation would rapidly collapse if all citizens were to pursue solely their own interests or those of their group. The stability of social cooperation relies on the majority of the participants cooperating willingly.

Earlier we had said Rawls supported a strict version of state neutrality, forbidding the state from actively concerning itself with the cultivation of citizens' virtue, relying instead solely on the beneficial effects of living under just laws and institutions (as will be further discussed in \$5.2.3). Sporadically, however, Rawls himself appears to be conscious of the untenability of such a strict form of neutrality. For example, in Political Liberalism he holds that if a state takes measures (such as discouraging religious and racial discrimination) to strengthen and promote the virtue of tolerance, it does not thereby become perfectionist: "Rather, it is taking reasonable measures to strengthen the forms of thought and feeling that sustain fair social cooperation between its citizens regarded as free and equal."75 Thus, at rare instances, even Rawls recognizes the legitimacy (and great importance) of the state's concern for the way its citizens think and feel; he appears to recognize here that we all have an interest in the state instilling those political virtues in its citizens that are necessary for a just and stable democratic order. Indeed, it seems clear that such cultivation of civic virtue differs greatly from the state advancing and promoting a particular comprehensive doctrine and is therefore still compatible with his political liberalism. In fact, in an illuminating discussion, Rawls compares political liberalism to classical republicanism 
and civic humanism (corresponding, respectively, to what we have been calling instrumental and intrinsic republicanism). He thereby understands classical republicanism as the view that the "safety of democratic liberties requires the active participation of citizens who possess the political virtues needed to maintain a constitutional regime" and concludes that such a position is by no means incompatible with political liberalism. ${ }^{76}$ Rawls himself thus provides us with several hints pointing towards the necessity of the cultivation of civic virtue by the state and the compatibility of such cultivation with a more moderate version of liberal neutrality: the state may take steps to cultivate civic virtue so long as the goal of such cultivation is not the imposition of a particular conception of the good life, but rather to ensure the stability of the political community. Civic virtue may be fostered. Personal virtue may not.

The earlier discussion (in Subsection 5.1.2) of the work of another prominent liberal - John Stuart Mill - confirmed that often liberals have been concerned with character formation. In fact, Mill himself even went so far as to maintain that the "principal element" of the idea of good government is "the improvement of the people themselves."77 Frequently, critics of liberalism have argued that liberal democracy presupposes certain character traits and dispositions that it, however, does not have the tools to create or sustain: "The procedural republic, it turns out, cannot secure the liberty it promises because it cannot inspire the moral and civic engagement self-government requires."78 However, the examples of Mill and (certain sparse passages in) Rawls might be able to prove this criticism unfounded. Certainly, this critique is germane to particular strains of liberalism (as found in the works of, e.g., Hobbes, Constant, Schumpeter as well as in the greater part of Rawls's political philosophy), but it is not so clearly applicable to a different strain of liberal political philosophy (to be found in, for example, the work of Mill, William Galston and in a number of rare passages of Rawls's writings). In fact, of late there have been several attempts to conceptualize a political philosophy that could unite liberalism and republicanism, precisely because of the belief that a particular strand of liberal-

76. Ibid. 205. Civic humanism, by contrast, promotes active participation of citizens in public life not because it is conducive to the stability of the political community, but rather because participation in public life is the quintessential good life for the political animals that humans are. As such, it is a comprehensive doctrine and therefore incompatible with political liberalism, which eschews comprehensive doctrines in order to achieve an overlapping consensus (ibid. 206).

77. Mill. Considerations on Representative Government. 243.

78. Sandel. Democracy's Discontent. 323. The "procedural republic" is Sandel's term for what he views as the prevailing (liberal) public philosophy in the United States, which he finds excessively neutral and overly rights-based. For a similar formulation of this "paradox of liberalism" see Fleming \& McClain. Ordered Liberty. 85. 
ism and instrumental republicanism are potentially compatible. ${ }^{79}$

A final example illustrating that liberalism is not necessarily hostile to the notion of character formation by the government - and thus another reason why the outrage expressed by many human rights advocates at the promulgation of the various human duties declarations is rather curious - can be found in the Universal Declaration itself, a document not known for its anti-liberal character. In $\$ 3.2$, it was argued that the drafters of the Universal Declaration intended it to contain a strong formative function. This becomes apparent from the second paragraph of Article 26, which states that education ought to be "directed to the full development of the human personality" as well as to the promotion of certain virtues ("understanding, tolerance and friendship"), which contribute to the protection and fulfillment of the human rights of all. Education, according to the drafters of the UDHR, ought to not only educate children in the fields of mathematics, languages, physics and so forth, but it must also instill in them certain virtues. Thus even the foundational human rights document calls for character formation.

Having argued that it is necessary for the stability of a democratic state, that it can be legitimate so long as the state refrains from imposing a comprehensive moral or religious doctrine, and that even prominent liberals and human rights documents call for it, concerns that the formation of citizens' dispositions by the state will lead to despotism or to a perfectionist utopia need no longer concern us. The cultivation of civic virtue by the state has thus been shown to be compatible with fundamental liberal principles, such as respect for rights and (a more moderate version of) liberal state neutrality.

\section{§ 5.2.3 - In What Manner May the State Cultivate Civic Virtue?}

Though the end of the promotion of civic virtue has been judged legitimate, the means by which the state undertakes such promotion could very well still be illegitimate. Is the state allowed, for example, to censure books and media arguing for "the virtue of selfishness?" May it install Orwellian "telescreens" in its citizens' homes in order to monitor their behavior and private conversations at all times? Ought it to be permissible for the state to use hypnopedia, as in Huxley's Brave New World, in order to saturate citizens' minds with civic virtue? The an- 
swer must be "no" in each of these and similar cases, even if we agree with the values being promoted and allow the state to promote them.

What, then, are acceptable ways for the state to instill civic virtue? I will distinguish three possibilities that are increasingly directly aimed at the cultivation of civic virtue. Firstly, one could view the very act of living under just laws as a legitimate way of cultivating civic virtue. Aristotle, for example, argued that we can be made good by laws. ${ }^{80}$ By telling us what we may and may not do, the laws function as a normative guide and as a key tool for the development of our character. Similarly, Kant argued that by preventing "the outbreak of unlawful inclinations" the law actually greatly facilitates "the development of the moral predisposition to immediate respect for right." 81 The laws do thus not only influence our external actions, but also the internal disposition that accompanies those actions. In other words, "the good moral education of a people is to be expected from a good state constitution." 82 More recently, Rawls has argued in a similar manner that just institutions (as defined by justice as fairness) instill a sense of justice in those who live under these arrangements. Rawls agrees with our earlier argument concerning the importance of civic virtue. He thus maintains that even when fully just principles are in place, first-person and free-rider egoism may still threaten the stability of the social system. Therefore, "[t]o insure stability men must have a sense of justice or a concern for those who would be disadvantaged by their defection, preferably both. When these sentiments are sufficiently strong to overrule the temptations to violate the rules, just schemes are stable." 83 Just laws and institutions are therefore in need of a widespread sense of justice among the citizenry, if they are to be stable. Rawls's solution for the development of this sense of justice is the benign influence of those very laws and institutions that were in need of a sense of justice in the first place.

This may appear to be a circular argument, but for Rawls it functions instead as a criterion for the laws and institutions that are to be set up: the basic institutions of a stable constitutional regime ought to be set up in such a manner that they "encourage the cooperative virtues of political life." ${ }^{44}$ When just insti-

80. Aristotle. (1934). Nicomachean Ethics. (H. Rackham, Trans.). Cambridge (Mass): Harvard University Press. 1130b24.

81. Kant, I. (1996). Toward Perpetual Peace. A Philosophical Project. In M. Gregor (Ed. \& Trans.), Practical Philosophy (pp. 316-351). Cambridge: Cambridge University Press. Ak 8:375-6n. Emphasis added.

82. Ibid. Ak. 8:366. Cf. Kant. Theory and Practice. Ak 8:304, where Kant argues that the "subjects' liberal way of thinking" is instilled in them by the constitution itself.

83. Rawls. A Theory of Justice. 435. Rawls understands a "sense of justice" to be "a settled disposition to adopt and to want to act from the moral point of view" (ibid. 430). It may therefore be viewed as akin to our usage of "civic virtue."

84. Rawls. Justice as Fairness. 116. 
tutions function well over time, Rawls assumes that these virtues will thereby be encouraged. Rawls's point here appears to be one of moral psychology. He maintains that it is a psychological law that our recognition of the benefits of living under enduring laws and institutions - provided they respect the two principles of justice of course -, "not only encourages mutual trust among citizens generally but also nurtures the development of attitudes and habits of mind necessary for willing and fruitful social cooperation." 85 Such laws and political institutions generate their own support, in the sense that "those who grow up in the well-ordered society in which that conception [i.e. a stable conception of justice] is realized normally develop ways of thought and judgment, as well as dispositions and sentiments, that lead them to support the political conception for its own sake." ${ }^{86}$ In this manner, just laws and institutions, themselves in need of civic virtue in order to be stable, actually generate the desired virtuous disposition on their own. ${ }^{87}$

The problem with this method of fostering civic virtue is, as mentioned in \$5.2.1, that its usefulness appears to be limited to ideal theory. In non-ideal circumstances, where the laws and institutions are not such that they generate their own support, other methods of instilling civic virtue will be needed.

A second legitimate method by which the state may cultivate civic virtue has already been discussed in our exposition of Mill's work, namely through the promotion of duties of civic participation. As civic participation consists in actions, performed by citizens, which address matters of public concern, it can help us to see beyond our own private interests and to take into consideration the common good as well as the interests of others. It helps us realize that we are not self-sufficient loose atoms, but rather that we are a part of a community that sustains us and that we, in turn, are obliged to help sustain. In Mill's words, civic participation forms a "school of public spirit."

The state may choose to render certain duties of civic participation obligatory, such as the duty to vote, the duty of military or civil service and the duty to serve as a juror. In these cases, participation becomes a legal duty. Often, however, such participation is deemed a matter of virtue, as is the case with neighborhood meeting attendance, being informed about current affairs and addressing patent injustices. In these cases, civic participation is a civic duty of virtue, the 
performance of which, however, may be encouraged by the government by informing the public about possibilities of civic participation, providing information concerning government plans and policy decisions, and by teaching young citizens in school about the importance of civic participation. As mentioned earlier, empirical research corroborates the claim that civic participation promotes the formation of civic skills and virtue. The problem, however, is that when civic participation is not legally required, it is often restricted to fairly limited segments of the society as a whole, ${ }^{88}$ namely those segments that tend to be more educated and better informed. Civic participation is therefore an effective tool for the formation of civic virtue, though problems of inclusion limit its success.

A third, perhaps more inclusive approach would be to teach civic virtue in schools. The education system must teach children how to take the standpoint of the (world ${ }^{89}$ ) citizen, that is, to be tolerant of others, to take into consideration the common good, to compromise, and to consider the public cause their business. Of course, viewing education as the best medium for instilling certain virtues is at least as old as Plato's Republic and Aristotle's Politics. In more modern times, we can find a fervent argument for public education in the work of Rousseau. He argues that education is to attach the child to the political community and teach her that she is nothing without it. Furthermore, education must be public in order to create a united and equal citizenry; Rousseau is very much opposed to a situation in which the children of the wealthy are educated differently and separately from poorer children; ${ }^{90}$ one imagines that such a system of education fails to create civic bonds and ties of solidarity between various groups in society, but instead pits them against one another. To avoid such an undesirable outcome, education must be public and thus the same for all if it is to have the desired effect:

If children are raised in common in the midst of equality, if they are imbued with the laws of the state and the maxims of the general will, if they are taught to respect them above all things, if they are surrounded by examples and objects that constantly speak to them . . . of the invaluable goods she [the republic] bestows on them, and

88. Michels. Innovations in Democratic Governance. 290-1.

89. A most notable example of an attempt to develop a curriculum on global citizenship education is provided by Oxfam (Oxfam (2009). Education for Global Citizenship. Retrieved from http://www.oxfam.org. uk/ /media/Files/Education/Global\%20Citizenship/education_for_global_citizenship_a_guide_for_ schools.ashx. The curriculum aims to encourage "children and young people to care about the planet and to develop empathy with, and an active concern for, those with whom they share it." 
of what they owe her in return, let us not doubt that this way they will learn to cherish one another as brothers, never to want anything but what the society wants. ${ }^{91}$

Of course, such a complete identification of the individual with the society (along with his questionable recommendations in Considerations on the Government of Poland that all teachers must be Poles and that children may not play freely but that rather even their games must be regulated and serve a common goal) prevents us from accepting Rousseau's account wholesale. Still, we need not accept all of Rousseau's eccentricities if we are to accept his basic point: education ought to play a great part in attaching children to the political community, teaching them crucial civic skills and instilling civic virtue. Even if we accept the right to freedom of education (i.e. parents' right to have their child be educated in a school that shares their religious or other beliefs), as is fitting for a pluralist society, we could still make the argument for an obligatory civics class to be taught in the same manner in all schools. One can imagine themes like the importance of tolerance for people with other sexual preferences to be unacceptable to very religious schools. Still, it appears to me that the state would be justified in nonetheless forcing these schools to teach their students about tolerance, as "it is impossible to live in peace with people one believes to be damned." 92

Similarly, one could argue that a democracy needs independent and critical citizens, who do not blindly follow authority but who can think for themselves, and that schools are perfectly placed to teach such skills. Again, there are undoubtedly parents (e.g., in relatively closed and traditional communities) who would prefer their children not learn such skills. Yet, we could respond that a democracy cannot be sustained by an uncritical citizenry that is either unable or unwilling to think for itself. Therefore, the government is justified in ensuring all children are taught to think independently by means of the educational system.

In sum, though we ought not to go as far as Rousseau in promoting the educational system as a seedbed of civic virtue, and we ought to leave room for diversity by ensuring freedom of education, we are nonetheless justified in maintaining that certain personal convictions and skills are not merely a private matter; when it comes to dispositions and skills that are necessary for the preser- 
vation of a pluralist democratic state, personal convictions are of public concern and the state is entitled to instill particular dispositions and teach certain skills by means of obligatory civics classes or other educational tools.

We have thus presented three legitimate means of civic virtue promotion by the state: (1) by living under just laws and institutions, (2) by promoting duties of civic participation, and (3) by utilizing the educational system. What is at stake in all three of these methods is creating critical, responsible and tolerant citizens, not because the state wishes to realize the good life for them, but rather because such citizens are needed for a stable political community. If this condition of "instrumentality" is respected and the methods of civic virtue promotion are acceptable, then it is just that, to a certain extent, one's private disposition be of public concern.

\section{$\S 5.3$ - Conclusion: Virtue as Complement to Justice}

Chapter 3 did a lot of work in clarifying the second set of controversial duties we set out to clarify, viz. duties to the community. Among other things, it made clear what duties we are talking about and what the status of these duties is. The first category of duties, the so-called civic duties of justice (containing such duties as the duty to obey the law and pay taxes), seemed relatively unproblematic. However, the two remaining civic duties (the sacrifices for the common good and the duty to perform one's duties willingly, which requires civic virtue) are a good deal more contentious. In our discussion of the human duties declarations in Chapter 1, we saw how critics feared that a renewed emphasis on (civic) duties might endanger our rights and that calls for a "global ethic" or for "voluntary self-obligation" run the risk of encouraging states' paternalistic tendencies. The present chapter therefore set out to take away such fears and show how instead a renewed emphasis on our civic duties and a concern for civic virtue are in fact beneficial to our rights and our freedom as well as for the stability and health of the political community.

First, Section $\$ 5.1$ focused on the civic duties Cassin had termed "sacrifices demanded for the common good." Such duties were found necessary for two reasons: (1) the performance of civic duties leads to an understanding of citizenship that is more active as well as more aware of the individual citizen's place within the political community as a whole; (2) the regular performance of civic duties is essential for the security of our rights. Furthermore, specifically with regard to duties of civic participation, we found (following our discussion of John Stuart 
Mill) four separate functions of the performance of such duties (educative, integrative, the stimulation of good government, and emancipative).

Subsequently, Section 5.2 provided an argument for the importance of the cultivation of civic virtue by the state that can avoid the hazards of paternalism. Firstly, §5.2.1 demonstrated that an overly strict version of liberal state neutrality is untenable, as it deprives us of the tools to cultivate civic virtue in non-ideal circumstances, whereas the need for civic virtue becomes evident immediately once we postulate a society in which it is wholly absent: in such a society, no one performs one's duties from conviction or from a sense of duty, but rather solely from fear for punishment or some other prudential reason (e.g., one does not cheat one's customers, not because it would be wrong, but rather because one does not wish to lose their business; or a politician's refusal to be corrupted stems not from the motive of duty, but simply because she fears she will not be reelected if it should be discovered). This community deprived of virtue is unstable, as all would cease to comply as soon as compliance would no longer be in their best interest. The stability of a political community, i.e. the reliable protection of rights and the preservation of its basic structure, thus relies on widespread civic virtue. Therefore, I concluded, the state may take measures to actively promote civic virtue. Strict liberal neutrality, which bars the state from any active involvement with citizens' virtue, is thus shown to be unsustainable.

Having established the importance of the fostering of civic virtue by the state, the next task was to further specify when it is legitimate for the state to concern itself with its citizens' virtue. This question was taken up in §5.2.2. In brief, it was argued that the state may take measures to promote civic virtue, but may not interfere with citizens' personal virtue by imposing a comprehensive moral or religious doctrine. In this manner, an important aspect of state neutrality is maintained (as the state remains neutral with regard to comprehensive doctrines), even though strict liberal neutrality (barring the state from any involvement with its citizens' virtue) is rejected.

Having argued thus far that the state may actively encourage civic virtue and when this may be done, it remained for us to clarify how the state may do so. Three different ways in which the state may legitimately cultivate civic virtue were therefore presented in \$5.2.3: through the beneficial influence of just laws and institutions, through the promotion of duties of civic participation and by means of the educational system.

More generally, this chapter contains a larger, but less explicit claim: though it is possible and at times very useful to draw a clear conceptual distinction be- 
tween justice and virtue, in practice we have found that often the two spheres of morality depend upon one another. True enough, the state's main task is to ensure justice, that is, to protect individual rights and freedoms as well as to set up and maintain just institutions. Yet, as I hope to have shown in this chapter, the preservation of such laws and institutions as well as the stable guarantee of individual rights and freedoms depends on the regular performance of civic duties of virtue as well as on the widespread presence of civic virtue. Thus, this chapter has provided a demonstration of the conceptual point made in Chapter 2 , namely that duties of virtue are not any less important than duties of justice and that, in fact, the performance of the former is of paramount import for the preservation of just institutions. Furthermore, as in Chapter 4, this chapter has demonstrated the importance of starting from our duties when inquiring what we ought to do. For if one, instead, adopts the perspective of rights, one remains blind to the duties of virtue discussed in this chapter, duties which have been shown to function as indispensable support to the sphere of justice, but which possess no correlative rights.

The calls for "voluntary self-obligation" and "human duties" (as found in the human duties declarations, but also, I have argued (in Section 3.2), in the Universal Declaration) are therefore more than warranted and do not deserve the fierce criticism they have received. Rather, those who insist on a strict form of liberal neutrality and categorically exclude state promotion of civic virtue as well as those who adopt the perspective of rights, risk endangering that which they hold most dear: the preservation of justice. Moreover, such calls do not pose any threat to individual rights. Rather, our rights discourse is hereby placed in a larger context, one in which justice and virtue, though conceptually distinct, are recognized to be interdependent spheres of morality. 



\section{CONCLUSION}

For surely such fellows are the most charming spectacle in the world when they enact and amend such laws as we just now described and are perpetually expecting to find a way of putting an end to frauds in business... because they can't see that they are in very truth trying to cut off a Hydra's head. ${ }^{1}$

They constantly try to escapel

From the darkness outside and within/

By dreaming of systems so perfect that no one will need to be good. ${ }^{2}$

In the Lectures on Ethics Kant imagines a world in which the strict compliance with the prescriptions of justice renders redundant the commands of virtue:

If we picture a man who acts only by right and not by kindness, he can always close his heart to any other man, and be indifferent to his wretched and pitiable fate, if he is but conscientious in observing his bounden duty to everyone, and does but accord to every man his right, as a sacred and most awesome trust that has been given to man by the ruler of the world. ${ }^{3}$

The passage is exemplary of the liberal belief that just government is in no need of a virtuous citizenry, but can suffice with just laws and institutions. This presents us with a strange inversion of Joel Feinberg's Nowheresville, which he describes as a world much like our own, but for one significant difference: no has any (or even knows of the concept of) rights, though the inhabitants are quite virtuous and regularly perform kindnesses. ${ }^{4}$ Instead, we are now imagining a community that knows only of rights and rights-corresponding duties, but lacks

1. Plato. The Republic. Book IV. 343.

2. Eliot, T. S. (1948). Choruses from “the Rock.” In Collected Poems 1909 - 1962. New York: Harcourt Brace \& Company. Chorus VI. 160.

3. Kant. Lectures on Ethics. Ak 27:415. This quote is followed by: "If he gives to no man a jot over his due, but is also punctilious in withholding nothing from him, he is acting righteously, and were we all to behave thus, and perform no act of love or kindness, but left the rights of every man inviolate, there would be no misery in the world," save that which stems from sickness and natural disasters); cf. ibid. Ak 27:432-3.

4. Feinberg. The Nature and Value of Rights. $143 \mathrm{ff}$. 
the idea of (duties of) virtue. We may call this community Commonplaceville, as this understanding of political community is typical of much contemporary work on political and legal philosophy. Arguably, such a community can be distilled from the writings of many contemporary political and legal philosophers, who would argue that all we require is a certain set of rights protected by just laws and institutions. Citizens need then only refrain from violating the rights of others, supposedly rendering the performance of duties of virtue and the possession of a virtuous disposition dispensable. The sphere of action not occupied by rights-based duties is considered to be entirely neutral, normatively speaking, allowing the agent to act in whichever way she pleases in that sphere. Any restriction of freedom - that is, any duty - not directly resultant from the rights of others, is therefore viewed with suspicion, as an illegitimate restriction of rightful freedom.

It is this understanding of a political community that has been challenged by the various human duties declarations of the past two decades, and it is the dominance of this view that accounts for the nearly unanimously negative reception of these declarations. The presence of duties of virtue in these declarations is considered to pose a potential threat to our rights: as rights are meant to ensure a sphere of free agency, which may be limited only by the rights of others, any duties (which are viewed as limitations of freedom) beyond duties of justice are viewed as endangering our rights and thus as impinging on that sphere of free agency. The talk of "voluntary self-obligation" and a global ethic is, furthermore, viewed as an unmistakable sign of the drafters' paternalistic tendencies: the disposition of citizens ought not to be of any concern to the state and has no place in declarations aspiring to the same status as the Universal Declaration of Human Rights.

In this dissertation, the debate between the drafters and the critics of the human duties declarations (expounded in Chapter 1) has functioned as a springboard for considering some more general, philosophical questions regarding, for instance, the interplay between duties and rights as well as the relation between justice and virtue. The greater point made in this study concerned the benefits of the adoption of the perspective of duties instead of the more common perspective of rights. Firstly, this shift of perspective allowed us to appreciate the importance of (duties of) virtue, which is all too often lost out of sight when one adopts the perspective of rights with its exclusive focus on matters of justice. By shifting perspective we are able to recognize the full scope of human duties, instead of focusing on rights-corresponding duties alone. Secondly, approaching normative questions from the perspective of duties rather than the perspective of rights permits 
us to define the content of duties more precisely as well as allocate them to specific duty-bearers. This ability is crucial in sorting genuine from spurious rights and thus halting the deleterious effects of human rights proliferation.

Regarding the latter point, Chapter 2 showed how the perspective of duties can provide a strict criterion with which one can distinguish genuine from spurious rights: namely, if the correlative duties are found to be duties of virtue, then the alleged right does not exist, as only duties of justice possess corresponding rights. This criterion was then applied to a concrete case study in Chapter 4: by examining our duties to the global poor and finding them to be - in the absence of global institutions that can clarify and allocate them - duties of virtue, we arrived at the conclusion that, at present, global subsistence needs do in fact not give rise to human rights to subsistence. The great advantage of focusing on our duties in this case is that we avoid unclaimable rights from arising, which threaten to diminish the force of human rights discourse as a whole and which engender false expectations.

The significance of the former point - viz. that the perspective of duties provides a richer moral landscape involving both (duties of) virtue and (duties of) justice - was demonstrated by emphasizing the importance of duties of virtue that go unnoticed by the perspective of rights. Thus, Chapter 5 argued that good laws and institutions, which constitute the domain of justice, do not suffice to safeguard the stability of a democratic political community; instead, the latter additionally requires the regular performance of civic duties as well as widespread civic virtue. Similarly, in Chapter 3, we found that the drafters of the Universal Declaration acknowledged the importance of instilling a sense of duty in citizens worldwide for the protection and realization of human rights. The idea being that just laws and human rights will function better and be more widely accepted when they are supported by such a disposition. There is thus a class of duties that the perspective of rights cannot account for, which, however, is crucial to the securing of those rights.

It is for these reasons that I have distanced myself from the criticism of redundancy heaped upon the human duties declarations. The second most common point of critique - that the human duties declarations pose a danger to our rights - is equally unfounded. Many critics look with suspicion upon calls for a global ethic and voluntary self-obligation, arguing that the drafters of these declarations wish citizens to be not simply law-abiding, but good. Yet, Chapter 5 has demonstrated that calls for virtue need not be problematic, so long as they are limited to civic virtue and do not extend to personal virtue. Moreover, the promotion of civic virtue is actually beneficial to justice, as it can help ensure the stability of a 
political community. A political community, by contrast, in which none comply with the laws and respect the rights of others from conviction, remains exposed to the threats of corruption and disorder. Chapter 3, furthermore, demonstrated that even the foundational human rights declaration - the Universal Declaration recognized the importance of instilling certain virtues in the citizenry in order to better secure the respect for and the fulfillment of human rights, rendering the vehement criticism from contemporary human rights scholars all the more puzzling.

Nor does the call for a renewed emphasis on our duties present a danger to human rights. Rather, as mentioned, it helps us preserve the strength of human rights discourse. A new focus on our duties allows us to gain a better understanding of what is at stake when rights are proclaimed, as was demonstrated in Chapter 4. Proclaiming rights without considering what will be required of whom to fulfill them is certainly convenient, but this approach risks human rights inflation, which threatens to weaken the status of all human rights. A focus on duties is without question less appealing than a focus on rights. Yet, without asking ourselves who ought to do what for whom in order to realize rights, claims to rights are bound to remain ineffective. Consequently, a call for a renewed focus on our duties is not only harmless, but actually of great benefit to our rights.

The importance of a renewed focus on our duties has thus been made clear, allowing us to definitely put to bed the charges of superfluity and danger. Yet, I feel I must reiterate that establishing the importance of duties does not imply the triviality of rights, or even that duties are more important than rights. Not without reason did this dissertation start out with a discussion of the historical shift from the primacy of duties to the primacy of rights. The Italian scholar Norberto Bobbio has adequately shown how much was gained by this shift: the individual went from being solely a part of a greater whole in which she had (nearly) no rights but only duties, to assuming center stage of the political arena, which henceforth would be committed to securing her rights; the state would from then on be considered legitimate only to the extent that it respected the individual and her rights. It requires no argument to see how great an improvement this shift represented. Perhaps it is from such a historical perspective, therefore, that some critics view the recent calls for a renewed emphasis on duty as a step back in the wrong direction.

It is not my intention to defend the various human duties declarations here. As said, they function rather as an occasion to discuss such matters as the relation between rights and duties, as well as the interplay between justice and virtue. Yet, I do believe the previous chapters have convincingly shown the need for 
a renewed emphasis on duties, including duties without corresponding rights, that is, duties of virtue. The point of such a renewed focus on duties is, emphatically, not to detract anything from the importance of rights. However, I have argued for a duties-based perspective on morality: firstly, because it will have a salutary effect on our human rights discourse by distinguishing more strictly between genuine and inauthentic rights; and secondly, because a duties-based approach enlarges the moral playing field, by recognizing both duties of justice and duties of virtue. The latter include such fundamental duties as duties to aid the global poor and civic duties, which function as indispensable complements to the duties prescribed by the sphere of justice.

These two sets of duties of virtue, which were the subject of respectively Chapter 4 and Chapter 5, might appear to be at odds with one another, as duties of global aid per definition make no distinction between fellow citizens and people generally, whereas the beneficiaries of civic duties appear to be limited to a particular political community and those residing in it. This is not necessarily the case, however. Civic virtue in particular need not be limited by national boundaries. We have defined civic virtue as the settled disposition to give precedence to the common good over one's own personal interests, yet this "common good" need not be limited to a particular state or political community. It may very well be extended beyond such limits and thus involve taking into consideration the regional and global ramifications of one's actions. Indeed, in $\S 3.2$, it was argued that Article 29(3) UDHR was meant to express the idea that the individual was not only a part of a national community, but also of the international community as a whole. That same section additonally pointed out that the civic virtue that Article 26(2) UDHR proposes be instilled through the educational system has global aspects as well - since it is meant to further the aims of the United Nations (such as the promotion and maintenance of peace) - and may therefore properly be referred to as cosmopolitan virtue. Civic virtue on a global scale - cosmopolitan virtue - would amount to considering the interests of the larger, global community as one's own interests: "a citizen of the world is one who recognizes duties and obligations to humanity as a whole and not merely to their national communities." ${ }^{5}$ Our duties to the global poor are exemplary of such duties to humanity as a whole. Their performance will greatly benefit from the cultivation of cosmopolitan virtue. Far from being in potential conflict with one another, the duties discussed in Chapter 4 could thus actually benefit from 
the duties discussed in Chapter 5 by, for example, extending the scope of civic virtue beyond the bounds of one's national political community.

As the call for a renewed focus on our duties is not meant to diminish the importance of rights, thus the arguments made in defense of (duties of) virtue in this dissertation are not intended to disparage the importance of (duties of) justice. Rather, the argument was made that (duties of) virtue can function as an essential complement to (duties of) justice. It is an argument that points out the limits of justice and the faultiness of the popular belief that just laws and institutions are enough to maintain a healthy political community.

Additionally, this argument does away with the common notion that one's actions beyond one's duties of justice are entirely discretionary. They are not. As was argued in Chapter 2, our imperfect duties of virtue are equally binding as our perfect duties of justice. One's sphere of discretionary action is, therefore, constrained not only by one's rights-corresponding duties, but additionally by such duties of virtue as the duty to aid those in need, the duty to contribute to the health of one's community (conceived in a national or supranational sense), and even duties to oneself (though these have not been discussed here).

Yet, by demonstrating the dependence of justice on virtue, I do not deny the obverse: justice is a necessary (but not sufficient) condition for the development of virtue. For an illustration of this point we can take our recourse, as we have done so often throughout the course of this dissertation, to an insightful distinction from the work of Kant. In the text Religion within the Boundaries of Mere Reason Kant distinguishes between a political and an ethical community, whereby the former is the organization of people under public laws of justice, which are all coercive laws (Zwangsgesetze), and the latter is a kingdom of virtue ruled by free Tugendgesetzen that may and cannot be enforced by external coercion. The necessary precondition for the forming of an ethical commonwealth is the prior existence of a political commonwealth, within which alone it can develop. ${ }^{6}$ For without justice, the path to virtue would be ridden with too many obstacles. In other words, justice helps clear a path for virtue to develop. Thus, in Idea for a Universal History Kant states that constant war inhibits the maturing of our latent moral capacities. ${ }^{7}$ Similarly, in Toward Perpetual Peace Kant contends that we all believe that we would abide by the prescriptions of justice, if only we 
could be assured others would do likewise. The government provides precisely such assurance by compelling those who would not willingly comply with the law. All can thus trust that their lawful actions will not be taken advantage of by others. This mutual trust greatly facilitates the "development of the moral predisposition to immediate respect for right." 8 It is, therefore, by removing obstacles to virtue that just laws and institutions facilitate its development.

Accordingly, the two realms of morality - justice and virtue - are to be considered as truly interdependent. We must, therefore, reject any choice between Nowheresville and Commonplaceville, as neither presents us with a desirable and viable form of community. Given, however, that the flaw of neglecting (duties of) virtue is a far more common defect of contemporary political and legal philosophy than the neglect of justice and rights, the promulgation of the various human duties declarations - calling for a renewed emphasis on duties and virtue - is a welcome initiative to establish a balance between rights and duties, between freedom and responsibility, and between justice and virtue. The preceding chapters can be read as a contribution to the realization of such a balance. 



\section{SUMMARY}

Traditionally, normative questions have been framed and discussed in terms of duties: Moses's two tablets command us to perform and refrain from performing certain actions; Cicero's De officiis, arguably the most influential ethical treatise of Roman antiquity, discusses the duties that we are bound to perform; even Immanuel Kant - viewed by many as a source of inspiration for the birth of human rights - considered moral philosophy to be a study of man's duties. Accordingly, the overarching question of Kant's practical philosophy is not "What are my rights?," but rather "What should I do?”. Today, instead, human rights discourse has become the global moral lingua franca. Whereas in the past, moral problems were analyzed in terms of duty (often to the exclusion of rights), today it has become nearly impossible to speak about normative matters in a way that does not include rights. Even when we do speak of duties, they are considered to be derivative of rights, which has now become the most fundamental moral category. The present dissertation is not a study of how this shift (from the dominance of duties to the dominance of rights in normative discourse) came about. Rather, it wishes to point out several problems with what I term the perspective of rights. Two problems in particular are discussed: firstly, the contemporary rights-based approach to morality is problematic, not because it promotes rights - any case made for a renewed attention for duty in this dissertation does not in any way wish to detract anything from rights -, but rather because it ignores or disparages those spheres of human normative agency that cannot be framed in terms of rights, leading to an impoverishment of moral discourse. An example of such a neglected moral category is that subset of our duties termed "duties of virtue," which occupies a place of prominence in this work. Given that rights are considered to be the most fundamental moral category, duties are held to exist only to the extent that they stem from rights. It follows that duties of virtue, which do not have any correlative rights, tend to be neglected.

A second problem with the rights-based perspective on morality is the tendency to speak of human rights without also considering the duties involved, resulting in the promulgation of a plethora of human rights without much attention for the corresponding duties. The detrimental consequence of this disregard for duties is the oft-noted and oft-bemoaned inflation of human rights. The popularity of human rights discourse has led to a proliferation of either mutually incompatible or simply implausible human rights claims, which damages the credibility of human rights discourse as such. 
Given these two serious problems with the perspective of rights - whereby one starts by identifying rights independently of duties and from there proceeds to define the corresponding duties - the main thesis of the present study is that we ought to adopt instead a perspective of duties, whereby one starts from duties and from there proceeds to identify our rights (if, indeed, the duty in question involves corresponding rights). This shift of perspective, firstly, allows us to recognize the full scope of human duties (instead of focusing solely on rights-corresponding duties) - thus enriching our moral landscape - as well as, secondly, neatly clarify the content of those duties and allocate them to specific duty-bearers, which will bring to a halt the great proliferation of dubious human rights claims. The goal of this work is, in other words, firstly to salvage those duties that are often neglected due to the dominance of the perspective of rights - namely duties of virtue - and to argue for their importance, and secondly to counter the trend of rights proliferation by providing some conceptual clarity concerning rights and duties that will enable us to differentiate between genuine and spurious claims to the status of "right."

In order to make these arguments, the dissertation is structured as follows. Chapter 1 discusses the debate that ensued from the promulgation of sundry human duties declarations over the past two decades. These declarations argued that especially Western liberal democracies overemphasize individual rights and personal freedom at the cost of our duties and of an understanding of freedom as involving necessarily a sense of responsibility. This imbalance between rights and duties, between freedom and responsibility, results, they maintain, in an unbridled individualism which could lead to conflict and discord.

These human duties declarations have been sharply criticized by human rights scholars. In general, the critics argue that such declarations are either superfluous, as human rights documents already make ample mention of rightsbased duties, or, insofar as the human duties declarations contain duties that go beyond rights-based duties, they are dangerous. The first chapter explores the debate between the drafters of the various human duties declarations and their critics. This chapter, furthermore, provides an overview of the individual duties present in the major human rights documents in order to assess the critics' claim concerning the superfluity of human duties declarations. This discussion then culminates in the selection of two individual duties that are particularly contentious, namely duties to the community (which can be found in Article 29 UDHR, but also, for example, in the African Charter) and duties of aid to the global poor (which can be understood to correlate with the human right to an 
adequate standard of living stated in, e.g., Article 25 UDHR and Article 11 ICESCR). These two duties function as case studies in chapters 3, 4 and 5.

Though this study thus starts with a discussion of the human duties declarations and the criticism they have received, it must be stressed that the goal of the present study is not to mount a defense of these declarations. The discussion of political and juridical documents - that is, the human duties and human rights documents - is not the main concern of this study. Rather, the proclamations of human duties declarations as well as the ensuing debate concerning their desirability serves as a springboard for reflections on the importance of a renewed focus on duties, the relation between rights and duties, the categorization of duties (perfect and imperfect duties, duties of justice and duties of virtue) and the relation between justice and virtue.

Accordingly, Chapter 2 starts by clarifying the central terms: rights, duties, justice and virtue. Furthermore, this chapter elucidates the relation between rights and duties, and argues that perfect duties of justice (that is, duties with corresponding rights) are not, as is so often erroneously held, more binding or of greater importance than imperfect duties of virtue (that is, duties without corresponding rights). Finally, the case is made for a duties-based perspective on morality instead of the by far more common rights-based perspective. In doing so, I have defended myself against critics who fear that a renewed focus on duties will necessarily be detrimental to our rights. I, therefore, needed to explain that a renewed attention for duties does not at all amount to, say, surrendering our rights and freedom to state power. On the contrary, rather than weakening or endangering human rights, a renewed emphasis on our duties will prove to strengthen human rights, particularly by preventing the proliferation of unclaimable rights. Starting from duties rather than rights, furthermore, will enable us to recognize the importance of duties of virtue, to which the perspective of rights must remain blind as the duties it recognizes are limited to rights-based duties, that is, duties of justice. Such duties of virtue, as is made clear in Chapters 4 and 5, are of crucial importance as complements to the sphere of justice.

It must be briefly pointed out that the exposition of the fundamental concepts provided in Chapter 2 is distinctly Kantian in nature. The nature of rights and duties, the distinctions between the various types of duties as well as the duties-based perspective on morality all find their origin in the work of Immanuel Kant, whereby I chiefly rely on The Metaphysics of Morals. The main reason for drawing from Kant's work is that his distinction between types of duties - i.e., between duties with corresponding rights (duties of justice) and duties without corresponding rights (duties of virtue) - as well as his understanding of a right 
as the ability to place others under obligations, allows us to provide some clarity in the jungle of rights claims by enabling us to distinguish genuine from spurious human rights. Chapter 2, in short, provides a theory of duties and rights, which allows us to resolve practical problems from the fields of human rights law and politics in the remaining three chapters, which discuss the two contentious duties singled out in Chapter 1. The discussion of these two case studies is meant to illustrate the advantages of the perspective of duties.

To begin, Chapter 3 examines what we can learn from human rights documents and human duties declarations regarding the nature of the duties correlative to the human right to an adequate standard of living and the duties to the community. Regarding the former, we found that such documents do not at all sufficiently clarify the nature of individual duties concerning global subsistence needs. Chapter 4, therefore, undertakes to provide such clarity by asking, firstly, who has what duties in fulfilling subsistence needs, secondly what the status of such duties is (are they duties of justice or duties of virtue?), and thirdly, whether subsistence needs do indeed give rise to a human right to subsistence. It is in this manner that Chapter 4 demonstrates how starting from duties can allow us to discriminate more precisely between genuine and (as yet) spurious rights.

Regarding the duties to the community, by contrast, the study of the relevant human rights documents - particularly the travaux préparatoires of the Universal Declaration - has proved to be far more fruitful. Still, many deem such duties owed by the individual to the community to constitute a threat to rights. In fact, it is these duties that are most often denounced by critics of the human duties declarations. Therefore, Chapter 5 illustrates that far from constituting a threat to our human rights, duties to the community are paramount to the preservation of a democratic political community, which, in turn, is instrumental in safeguarding our rights.

Finally, Chapter 5 also discusses the claim of several human duties declarations that rights without morality cannot long endure; what is needed, the drafters of such declarations claim, is "voluntary self-obligation." Even legal rights that can be coercively enforced will be more reliably secured if all respect such rights willingly, rather than merely for prudential reasons. The present study is in agreement with such statements and provides arguments, in Chapter 5, that illustrate why calls for a virtuous disposition need not serve a hidden paternalistic agenda, provided they are limited to appeals for civic rather than personal virtue. Chapter 5 thus provides us with an illustration of the importance of (duties of) virtue as complement to the sphere of justice. As such, it also demonstrates the desirability of the perspective of duties, for it can recognize such ethical du- 
ties to the community, whereas the perspective of rights can at best view them as optional excellences. 


\section{SAMENVATTING}

Voor het overgrote deel van de geschiedenis van de morele en politieke filosofie zijn normatieve vragen in termen van plichten geformuleerd en besproken: de twee stenen tabletten van Mozes gebieden ons bepaalde handelingen uit te voeren (of om ons juist daarvan te onthouden); Cicero's De officiis, misschien wel de meest invloedrijke ethische verhandeling van de Romeinse oudheid, bespreekt de plichten die we moeten vervullen; zelfs Immanuel Kant - door velen gezien als een bron van inspiratie voor de geboorte van de mensenrechten - beschouwt de morele filosofie als een studie van plichten. Bijgevolg is de overkoepelende vraag van Kants praktische filosofie niet "Wat zijn mijn rechten?," maar veeleer "Wat moet ik doen?". In tegenstelling tot deze traditie, heeft tegenwoordig het mensenrechtendiscours de functie van wereldwijde morele lingua franca verworven. Terwijl in het verleden morele problemen in termen van plichten werden bestudeerd (waarbij rechten zelden mede in overweging werden genomen), is het tegenwoordig bijna onmogelijk geworden om zonder gebruik van het concept "recht" normatieve kwesties te bespreken. Zelfs wanneer we wel over plichten spreken, worden deze als afgeleide van rechten beschouwd, die nu de meest fundamentele morele categorie zijn gaan vormen. Dit proefschrift is niet een studie van hoe deze verschuiving (van de dominantie van plichten naar de dominantie van rechten in het normatieve discours) tot stand is gekomen. Het wil veeleer de lezer wijzen op verschillende problemen met wat ik het rechtenperspectief noem. Twee problemen in het bijzonder worden besproken: ten eerste, de hedendaagse, op rechten gebaseerde benadering van de moraal is problematisch, niet omdat het rechten bevordert - de argumenten die in dit proefschrift worden gemaakt voor een hernieuwde aandacht voor de plicht willen op geen enkele wijze iets afdoen aan het belang van rechten -, maar omdat het die sferen van het menselijk handelen buiten beschouwing laat of bagatelliseert die niet in termen van rechten geformuleerd kunnen worden, hetgeen leidt tot een verarming van het morele discours. Een voorbeeld van een dergelijke verwaarloosde morele categorie (een die in dit werk een prominente plek inneemt) is de deugdplicht. Aangezien rechten worden beschouwd als de meest fundamentele morele categorie, erkent men het bestaan van plichten alleen voor zover deze uit rechten voortvloeien. Hieruit volgt dat deugdplichten, die immers geen corresponderende rechten hebben, vaak worden veronachtzaamd.

Een tweede probleem met het rechtenperspectief op de moraal is de neiging om over mensenrechten te spreken zonder enige rekening te houden met de 
corresponderende plichten, hetgeen resulteert in de afkondiging van een reeks mensenrechten zonder enige aandacht aan de bijbehorende plichten te schenken. Het schadelijke gevolg van deze geringschatting van de plicht is de vaak opgemerkte en vaak betreurde inflatie van de mensenrechten. De populariteit van het mensenrechtendiscours heeft geleid tot een wildgroei aan mensenrechten die oftewel onderling incompatibel of simpelweg ongeloofwaardig zijn, hetgeen de geloofwaardigheid van het mensenrechtendiscours als zodanig schaadt.

Gezien deze twee ernstige problemen met het rechtenperspectief - waarbij men begint met het identificeren van rechten onafhankelijk van de plichten, om van daaruit vervolgens de bijbehorende plichten te bepalen - is de centrale stelling van deze studie dat we beter kunnen kiezen voor een plichtenperspectief, waarbij men uitgaat van de plichten en van daaruit vervolgens onze rechten identificeert (wanneer, tenminste, de desbetreffende plicht bijbehorende rechten met zich meebrengt). Deze perspectiefverschuiving stelt ons, ten eerste, in staat om de volledige omvang van mensenplichten te erkennen (in plaats van ons uitsluitend te concentreren op plichten met bijbehorende rechten), waardoor ons morele landschap verrijkt wordt. Ten tweede kunnen wij hierdoor zowel de inhoud van deze plichten verduidelijken als ze toewijzen aan specifieke dragers van plichten. Dit zal leiden tot het stopzetten van de grote toename van dubieuze mensenrechten. Het doel van dit werk, met andere woorden, is om ten eerste die plichten te behouden die vaak worden verwaarloosd als gevolg van de dominantie van het rechtenperspectief - namelijk de deugdplichten - en om te pleiten voor het belang van deze plichten. Ten tweede wil deze studie de wildgroei aan mensenrechten tegengaan door enige conceptuele duidelijkheid over rechten en plichten te verschaffen die ons in staat stelt om onderscheid te maken tussen terechte en onterechte aanspraken op de status van "recht."

Om deze punten te maken, is het proefschrift als volgt opgebouwd. Hoofdstuk 1 bespreekt de discussie die voortvloeide uit de publicatie van diverse mensenplichtenverklaringen. Deze verklaringen stelden dat vooral de westerse liberale democratieën individuele rechten en persoonlijke vrijheid benadrukken ten koste van onze plichten en van een concept van vrijheid dat noodzakelijkerwijs een verantwoordelijkheidsbesef met zich meebrengt. Dit gebrek aan evenwicht tussen rechten en plichten, tussen vrijheid en verantwoordelijkheid, resulteert, menen zij, in een ongebreideld individualisme dat tot conflict en verdeeldheid kan leiden.

Deze mensenplichtenverklaringen zijn scherp bekritiseerd door mensenrechtengeleerden. In het algemeen beweren de critici dat dergelijke verklaringen ofwel overbodig zijn, aangezien mensenrechtendocumenten reeds uitgebreid 
aandacht besteden aan uit rechten voortvloeiende plichten, ofwel gevaarlijk, voor zover de mensenplichtenverklaringen plichten bevatten die verder gaan dan de op rechten gebaseerde plichten. Het eerste hoofdstuk onderzoekt het debat tussen de opstellers van de verschillende mensenplichtenverklaringen en hun critici. Dit hoofdstuk verschaft bovendien een overzicht van de individuele plichten die in de belangrijkste mensenrechtendocumenten vervat liggen om het punt aangaande de overbodigheid van de mensenplichtenverklaringen te kunnen beoordelen. Deze discussie loopt dan uit op de selectie van twee individuele plichten die bijzonder omstreden zijn, namelijk plichten jegens de gemeenschap (die in artikel 29 van de Universele Verklaring van de Rechten van de Mens (UVRM) gevonden kunnen worden, maar ook bijvoorbeeld in het Afrikaans Handvest voor de Mensenrechten) en hulpverplichtingen met betrekking tot wereldwijde armoede (welke plichten men kan beschouwen als correlerend met het mensenrecht op een adequate levensstandaard zoals vermeld in, bijvoorbeeld, artikel 25 UVRM en artikel 11 van het Internationaal Verdrag inzake economische, sociale en culturele rechten). Deze twee plichten fungeren als "case studies" in de hoofdstukken 3, 4 en 5.

Hoewel dit onderzoek dus begint met een bespreking van de mensenplichtenverklaringen en de kritiek die zij hebben ontvangen, is het doel van dit werk met nadruk niet om deze verklaringen te verdedigen. De bespreking van politieke en juridische documenten - dat wil zeggen, de mensenplichten- en mensenrechtendocumenten - is niet de hoofdzaak van deze studie. De afkondiging van mensenplichtenverklaringen, evenals het daaruit voortvloeiende debat over de wenselijkheid daarvan, dient als springplank voor bespiegelingen op het belang van een hernieuwde focus op plichten, de relatie tussen rechten en plichten, de indeling van plichten (perfect en imperfecte plichten, rechtvaardigheidsplichten en deugdplichten) en de relatie tussen rechtvaardigheid en deugd.

Derhalve begint Hoofdstuk 2 met een verduidelijking van de centrale begrippen: rechten, plichten, rechtvaardigheid en deugd. Verder verheldert dit hoofdstuk de relatie tussen rechten en plichten, en stelt het dat perfecte rechtvaardigheidsplichten (dat wil zeggen, plichten met bijbehorende rechten) niet, zoals zo vaak ten onrechte wordt beweerd, meer bindend of van groter belang zijn dan imperfecte deugdplichten (dat wil zeggen, rechten zonder bijbehorende rechten). Tenslotte wordt gepleit voor een plichtenperspectief op de moraal in plaats van het veruit meer gangbare rechtenperspectief. Daarbij moet ik mezelf verdedigen tegen critici die vrezen dat een hernieuwde focus op de plicht schadelijke gevolgen voor onze rechten zal hebben. Ik moet daarom uitleggen dat een hernieuwde aandacht voor de plicht geenszins een overgave van onze rechten en 
vrijheid aan de staat behelst. Integendeel, in plaats van onze mensenrechten te verzwakken of in gevaar te brengen, zal blijken dat een hernieuwde nadruk op onze plichten de mensenrechten juist versterkt, met name door het voorkomen van de verspreiding van rechten die niet geclaimd kunnen worden. Door plichten in plaats van rechten als ons uitgangspunt te nemen, zijn we bovendien in staat om het belang van deugdplichten te erkennen. Voor deze plichten moet het rechtenperspectief noodzakelijkerwijs blind blijven, omdat het enkel op rechten gebaseerde plichten erkent, dat wil zeggen, rechtvaardigheidsplichten. Deze deugdplichten, zoals duidelijk wordt gemaakt in de hoofdstukken 4 en 5, vormen echter een cruciale aanvulling op de sfeer van rechtvaardigheid.

Het moet kort worden opgemerkt dat de uiteenzetting van de fundamentele begrippen in Hoofdstuk 2 een duidelijk Kantiaanse achtergrond heeft. De aard van de rechten en plichten, het onderscheid tussen de verschillende soorten plichten, alsmede het plichtenperspectief op de moraal vinden alle hun oorsprong in het werk van Immanuel Kant, waarbij ik vooral een beroep doe op zijn late werk Die Metaphysik der Sitten. De belangrijkste reden om van Kants werk gebruik te maken, is dat zijn onderscheid tussen soorten plichten - dat wil zeggen, tussen plichten met bijbehorende rechten (rechtvaardigheidsplichten) en plichten zonder bijbehorende rechten (deugdplichten) - evenals zijn begrip van een recht als het vermogen om anderen een bindende verplichting op te leggen, ons wat meer duidelijkheid kunnen bieden in de jungle van rechtsaanspraken door ons in staat te stellen om echte van vermeende mensenrechten te onderscheiden. Hoofdstuk 2 biedt, kort gezegd, een theorie van plichten en rechten die ons in staat stelt om in de resterende drie hoofdstukken praktische problemen op het gebied van de mensenrechten en de politiek op te lossen. In deze hoofdstukken worden de twee omstreden plichten besproken die uit Hoofdstuk 1 naar voren kwamen. De bespreking van deze twee case studies is bedoeld om de voordelen van het plichtenperspectief te illustreren.

Om te beginnen onderzoekt Hoofdstuk 3 wat mensenrechtendocumenten en mensenplichtenverklaringen ons kunnen leren over de aard van de plichten jegens de gemeenschap en de plichten die correleren met het mensenrecht op een adequate levensstandaard. Wat betreft de laatstgenoemde moeten we concluderen dat deze documenten de aard van de individuele plichten met betrekking tot mondiale armoede in het geheel niet voldoende weten te verduidelijken. Derhalve is het het doel van Hoofdstuk 4 om deze duidelijkheid te verschaffen door, ten eerste, te vragen wie welke plichten heeft met betrekking tot het recht op een adequate levensstandaard; ten tweede, wat de status van deze plichten is (zijn het rechtvaardigheidsplichten of deugdplichten?); en, ten derde, of er 
werkelijk sprake is van een mensenrecht op een fatsoenlijke levensstandaard. Op deze wijze laat Hoofdstuk 4 zien hoe wij door plichten als ons uitgangspunt te nemen beter in staat zijn om op meer precieze wijze tussen echte en (vooralsnog) slechts vermeende rechten te onderscheiden.

Met betrekking tot de plichten jegens de gemeenschap, daarentegen, heeft het bestuderen van de relevante mensenrechtendocumenten in Hoofdstuk 3 - met name de travaux préparatoires - wel vruchten afgeworpen. Desalniettemin beschouwen velen deze plichten die het individu aan de gemeenschap verschuldigd is als een bedreiging voor onze rechten. Het zijn dan ook deze plichten die het vaakst door critici van de mensenplichtenverklaringen worden veroordeeld. Derhalve wil Hoofdstuk 5 laten zien dat verre van een bedreiging voor onze mensenrechten te vormen, plichten jegens de gemeenschap juist van cruciaal belang zijn voor het in stand houden van een democratische politieke gemeenschap, welke laatste weer van grootse waarde is voor de bescherming van onze rechten.

Tot slot bespreekt Hoofdstuk 5 nog de bewering van verschillende mensenplichtenverklaringen dat rechten zonder moraal geen lang leven beschoren is; de opstellers van deze verklaringen menen dat "vrijwillige zelfverplichting" noodzakelijk is. Zelfs rechten die afgedwongen kunnen worden, kunnen op meer betrouwbare wijze worden gewaarborgd wanneer allen dergelijke rechten uit vrije wil en overtuiging respecteren, in plaats van slechts om zelfzuchtige redenen. Het voorliggende onderzoek sluit zich hierbij aan en biedt in Hoofdstuk 5 verschillende argumenten die aantonen dat oproepen voor een deugdzame gezindheid onder burgers geen verborgen paternalistische agenda hoeft te dienen, mits de oproepen zich beperken tot burgerlijke deugd in plaats van persoonlijke deugd. Hoofdstuk 5 geeft ons dus een voorbeeld van het belang van de deugd en deugdplichten als aanvulling op de sfeer van de rechtvaardigheid. Als gevolg toont het eveneens de wenselijkheid van het plichtenperspectief. Dit perspectief kan namelijk wel dergelijke ethische plichten jegens de gemeenschap erkennen, terwijl het rechtenperspectief deze hooguit als vrijblijvende opties voor handelen kan beschouwen. 



\section{BIBLIOGRAPHY}

Anscombe, G. E. M. (2005). Who is Wronged? Philippa Foot on Double Effect: One Point. In M. Geach \& L. Gormally (Eds.), Human Life, Actions and Ethics. Essays by G.E.M. Anscombe (pp. 249-251). Exeter: Imprint Academic.

Aristotle. (1934). Nicomachean Ethics. (H. Rackham, Trans.). Cambridge (Mass): Harvard University Press.

Aristotle. (1944). Politics. (H. Rackham, Trans.). Cambridge (Mass): Harvard University Press.

Ashford, E. (2006). The Inadequacy of our Traditional Conception of the Duties Imposed by Human Rights. Canadian Journal of Law and Jurisprudence, XIX(2), 217-235.

Ashford, E. (2007). The Duties Imposed by the Human Right to Basic Necessities. In T. Pogge (Ed.), Freedom from Poverty as a Human Right: Who Owes What to the Very Poor? (pp. 183-218). Oxford: Oxford University Press.

Baron, M. (1995). Kantian Ethics Almost Without Apology. Ithaca: Cornell University Press.

Beddard, R. (1999). Duties of individuals under international and regional human rights instruments. The International Journal of Human Rights, 3(4), 30-48.

Berkowitz, P. (1999). Virtue and the Making of Modern Liberalism. Princeton: Princeton University Press.

Bobbio, N. (2009). Il primato dei diritti sui doveri. In M. Bovero (Ed.), Teoria Generale della Politica (pp. 431-440). Torino: Giulio Einaudi.

Bojic Bultrini, D. (2009). Guide on Legislating for the Right to Food. Rome: Food and Agriculture Organization of the United Nations.

Buchanan, A. (1987). Justice and Virtue. Ethics, 97(3), 558-575.

Burtt, S. (1990). The Good Citizen's Psyche: On the Psychology of Civic Virtue. Polity, 23(1), 23-38.

Cannie, H., \& Voorhoof, D. (2011). The Abuse Clause and Freedom of Expression in the European Human Rights Convention: An Added Value for Democracy and Human Rights Protection? Netherlands Quarterly of Human Rights, 29(1), 54-83.

Cassin, R. (1972). La Pensée et l'Action. Boulogne-sur-Seine: Editions F. Lalou.

Chen, S., \& Ravallion, M. (2013). More Relatively-Poor People in a Less Absolutely-Poor World. Review of Income and Wealth, 59(1), 1-28.

Chinkin, C. (2010). Sources. In D. Moeckli, S. Shah, \& S. Sivakumaran (Eds.), International Human Rights Law (pp. 103-123). Oxford: Oxford University Press.

Cicero. (2001). On Obligations. (P. G. Walsh, Trans.). Oxford: Oxford University Press.

Clapham, A. (2006). Human Rights Obligations of Non-State Actors. Oxford: Oxford University Press.

Cohen, R. (1993). Endless Teardrops: Prolegomena to the Study of Human Rights in Africa. In R. Cohen (Ed.), Human Rights and Governance in Africa (pp. 3-38). Gainesville (FL): Florida University Press.

Constant, B. (1988). The Liberty of Ancients Compared with that of Moderns. In B. Fontana (Ed. \& Trans.), Political Writings (pp. 307-328). Cambridge: Cambridge University Press.

Committee of Ministers of the Council of Europe. Recommendation No. R 97 (20) on "hate speech" (adopted on 30 October 1997). Retrieved from http://www.coe.int/t/dghl/standardsetting/hrpolicy/other_committees/dh-lgbt_docs/CM_Rec(97)20_en.pdf.

Curtis, J., \& Darcy, S. (2012). The Right to a Social and International Order for the Realisation of Human Rights: Article 28 of the Universal Declaration and International Cooperation. In D. Keane \& Y. McDermott (Eds.), The Challenge of Human Rights: Past, Present and Future (pp. 9-35). Cheltenham: Edward Elgar Publishing.

Daes, E.-I. (1990). Freedom of the Individual under Law: an Analysis of Article 29 of the Universal Declaration of Human Rights. Geneva: Centre for Human Rights.

Dagger, R. (1997). Civic Virtues: Rights, Citizenship, and Republican Virtues. Oxford: Oxford University Press. 149. Cf. Rawls. Legal Obligation and the Duty of Fair Play.

De Schutter, O. (2006). Transnational Corporations and Human Rights. Oxford: Hart Publishing.

De Schutter, O. (2010). Countries Tackling Hunger with a Right to Food Approach: Briefing note 1. UN Special Rapporteur on the Right to Food.

Devereux, A. (1995). Should "Duties" Play a Larger Role in Human Rights? A critique of Western Liberal and African Human Rights Jurisprudence. UNSW Law Journal, 18(2), 464-482.

Dworkin, R. (1997). Taking Rights Seriously. London: Duckworth.

Dworkin, R. (2011). Justice for Hedgehogs. Cambridge, Mass: Belknap Press of Harvard University Press.

Eleftheriadis, P. (2010). On Rights and Responsibilities. Public Law, 31, 33-45.

Eliot, T. S. (1948). Collected Poems 1909 - 1962. New York: Harcourt Brace \& Company.

Etinson, A. (2013). Human Rights, Claimability and the Uses of Abstraction. Utilitas, 25(4), 463-486.

Feinberg, J. (1980). The Nature and Value of Rights. In Rights, Justice, and the Bounds of Liberty: Essays in Social Philosophy (pp. 143-158). Princeton: Princeton University Press.

Feinberg, J. (1984). The Moral and Legal Responsibility of the Bad Samaritan. Criminal Justice Ethics, 3(1), 56-69.

Feinberg, J. (1984). The Moral Limits of the Criminal Law. Volume One: Harm to Others. New York: Oxford University

Press. 
Fleming, J. E., \& McClain, L. C. (2013). Ordered Liberty. Cambridge (Mass): Harvard University Press.

Flikschuh, K. (2011). On the Cogency of Human Rights. Jurisprudence, 2(1), 17-36.

Flikschuh, K., \& Ypi, L. (Eds.). (2014). Kant and Colonialism: Historical and Critical Perspectives. Oxford: Oxford University Press;

Follesdal, A., \& Maliks, R. (Eds.). (2014). Kantian Theory and Human Rights. New York: Routledge;

Fraser, M. (2005). Human Responsibilities and Human Rights in the Age of Terrorism. High Level Expert Group Meeting on Human Rights and Human Responsibilities in the Age of Terrorism. April 1-2. Santa Clara University. Retrieved from http://www.scu.edu/ethics/practicing/focusareas/global_ethics/ laughlin-lectures/rights-responsibility-fraser.html.

Galston, W. A. (1988). Liberal Virtues. The American Political Science Review, 82(4), 1277-1290.

Gerards, J.H. (2013). Artikel 10 EVRM - vrijheid van meningsuiting. In J.H. Gerards et al. (red.), Sdu Commentaar EVRM. Deel 1 - materiële bepalingen (pp. 856-1024). Den Haag: Sdu.

Gewirth, A. (1987). Private Philanthropy and Positive Rights. Social Philosophy \& Policy, 4(2), 55-78. 58.

Gilabert, P. (2005). The Duty to Eradicate Global Poverty: Positive or Negative? Ethical Theory and Moral Practice, 7, 537-550.

Gilabert, P. (2010). Kant and the Claims of the Poor. Philosophy and Phenomenological Research, 81(2), 382-418.

Glendon, M. A. (1991). Rights Talk: The Impoverishment of Political Discourse. New York: The Free Press.

Glendon, M. A. (1998). Knowing the Universal Declaration of Human Rights. Notre Dame Law Review, 73, $1153-1176$.

Glendon, M.A. (2001). A World Made New: Eleanor Roosevelt and the Universal Declaration of Human Rights. New York: Random House.

Griffin, J. (2008). On Human Rights. Oxford: Oxford University Press.

Grotius, H. (2005). The Rights of War and Peace. (J. Barbeyrac, Trans, R. Tuck, Ed.). Indianapolis: Liberty Fund.

Hart, H. L. A. (1955). Are There Any Natural Rights? The Philosophical Review, 64(2), 175-191.

Hart, H.L.A. (1982). Essays on Bentham: Jurisprudence and Political Philosophy. Oxford: Oxford University Press.

Hegel, G. W. F. (1986). Grundlinien der Philosophie des Rechts oder Naturrecht und Staatswissenschaft im Grundrisse. Frankfurt am Main: Suhrkamp Verlag.

Held, D. (2006). Models of Democracy (Third edit.). Cambridge: Polity Press.

Heyns, C., \& Killander, M. (2010). Africa. In D. Moeckli, S. Shah, \& S. Sivakumaran (Eds.), International Human Rights Law (pp. 479-497). Oxford: Oxford University Press.

Hill, T. E. (1971). Kant on Imperfect Duty and Supererogation. Kant-Studien, 62(1-4), 55-76.

Hobbes, T. (1996). Leviathan. (R. Tuck, Ed.) (Revised Student Edition). Cambridge: Cambridge University Press. Hodgson, D. (2003). Individual Duty within a Human Rights Discourse. Aldershot: Ashgate.

Höffe, O. (1990). Kategorische Rechtsprinzipien: Ein Kontrapunkt der Moderne. Frankfurt am Main: Suhrkamp.

Hohfeld, W. N. (1913). Some Fundamental Legal Conceptions as Applied in Judicial Reasoning. The Yale Law Journal, 23(1), 16-59.

Hope, S. (2013). Subsistence Needs, Human Rights, and Imperfect Duties. Journal of Applied Philosophy, 30(1), 88-100.

Hope, S. (2014). Kantian Imperfect Duties and Modern Debates over Human Rights. The Journal of Political Philosophy, 22(4), 396-415

Horace. (2008). The Odes of Horace. (J. H. Kaimowitz, Trans.). Baltimore: Johns Hopkins University Press.

Horn, C. (2014). Nichtideale Normativität: Ein neuer Blick auf Kants politische Philosophie. Berlin: Suhrkamp.

International Council on Human Rights Policy. (1999). Taking Duties Seriously: Individual Duties in International Human Rights Law. A Commentary. Versoix (Switzerland).

Kant, I. (1907). Die Metaphysik der Sitten. In Kants Werke. Bd. 6: Die Religion innerhalb der Grenzen der bloßen Vernunft. Die Metaphysik der Sitten (pp. 203-493). Ausgabe der Königlich Preußischen Akademie der Wissenschaften. Berlin: Walter de Gruyter.

Kant, I. (1963). Idea for a Universal History from a Cosmopolitan Point of View. In L. W. Beck (Ed.), L. W. Beck (Trans.), Kant: On History (pp. 11-26). New York: Macmillan.

Kant, I. (1968). Vorarbeiten zur Tugendlehre. In Kants Werke. Bd. 23: Vorarbeiten und Nachträge (pp. 371-420). Ausgabe der Königlich Preußischen Akademie der Wissenschaften. Berlin: Walter de Gruyter.

Kant, I. (1996). Critique of Practical Reason. In M. Gregor (Ed. \& Trans.), Practical Philosophy (pp. 137-271). Cambridge: Cambridge University Press.

Kant, I. (1996). Groundwork of The Metaphysics of Morals. In M. Gregor (Ed. \& Trans.), Practical Philosophy (pp. 41-108). Cambridge: Cambridge University Press.

Kant, I. (1996). On a Supposed Right to Lie from Philanthropy. In M. Gregor (Ed. \& Trans.), Practical Philosophy (pp. 611-615). Cambridge: Cambridge University Press.

Kant, I. (1996). On the Common Saying: That May Be Correct in Theory, But Is of No Use in Practice. In M. Gregor (Ed. \& Trans.), Practical Philosophy (pp. 277-309). Cambridge: Cambridge University Press.

Kant, I. (1996). Religion within the Boundaries of Mere Reason. In A. Wood \& P. Guyer (Eds.), G. Di Giovanni (Trans.), Religion and Rational Theology (pp. 39-215). Cambridge: Cambridge University Press.

Kant. I. (1996). Review of Hufeland's “Essay on the Principle of Natural Right. In M. Gregor (Ed. \& Trans.), Practical Philosophy (pp. 113-117). Cambridge: Cambridge University Press.

Kant, I. (1996). The Conflict of the Faculties. In A. Wood \& P. Guyer (Eds.), M. Gregor \& R. Anchor (Trans.), Religion 
and Rational Theology (pp. 237-327). Cambridge: Cambridge University Press.

Kant, I. (1996). The Metaphysics of Morals. In M. Gregor (Ed.), M. Gregor (Trans.), Practical Philosophy (pp. 363603). Cambridge: Cambridge University Press.

Kant, I. (1996). Toward Perpetual Peace. A Philosophical Project. In M. Gregor (Ed. \& Trans.), Practical Philosophy (pp. 316-351). Cambridge: Cambridge University Press.

Kant, I. (1997). Lectures on Ethics. (P. Heath, Trans., P. Heath \& J. B. Schneewind, Eds.). Cambridge: Cambridge University Press.

Katz Cogan, J. (2011). The Regulatory Turn in International Law. Harvard International Law Journal, 52(2), $321-372$.

Kersting, W. (1984). Wohlgeordnete Freiheit: Immanuel Kants Rechts- und Staatsphilosophie. Berlin: Walter de Gruyter.

Kersting, W. (2004). Kant über Recht. Paderborn: Mentis Verlag.

Kleingeld, P. (2012). Kant and Cosmopolitanism: the Philosophical Idea of World Citizenship. Cambridge: Cambridge University Press

Knox, J. H. (2008). Horizontal Human Rights Law. American Society of International Law, 102(1), 1-47.

Koffeman, N.R. (The Right to) Personal Autonomy in the Case Law of the European Court of Human Rights (nota opgesteld ten behoeve van de Staatscommissie Grondwet). Leiden: Leiden University, 2010.

Kraut, R. (2002). Aristotle: Political Philosophy. Oxford: Oxford University Press.

Kreide, R. (2007). Neglected Injustice: Poverty as a Violation of Social Autonomy. In T. Pogge (Ed.), Freedom From Poverty as a Human Right: Who Owes What to the Very Poor? (pp. 155-181). Oxford: Oxford University Press.

Küng, H. (1998). Human Responsibilities Reinforce Human Rights: The Global Ethic Project. In B. van der Heijden \& B. Tahzib-Lie (Eds.), Reflection of the Universal Declaration of Human Rights: A Fiftieth Anniversary Anthology (165-168). The Hague: Kluwer Law International.

Kymlicka, W. (2002). Contemporary Political Philosophy: An Introduction (2 ${ }^{\text {nd }}$ ed.). Oxford: Oxford University Press. Lafont, C. (2010). Accountability and Global Governance: Challenging the State-Centric Conception of Human Rights. Ethics and Global Politics, 3(3), 193-215

Lazarus, Liora et al. The Relationship Between Rights and Responsibilities (December 12009$)$. Ministry of Justice Research Paper No. 18/09. Retrieved from http://ssrn.com/abstract=2022270 or http://dx.doi. org/10.2139/ssrn.2022270.

Lesser, A. H. (Ed.). (2015). Kant's 'Doctrine of Right' in the Twenty-first Century. Cardiff: University of Wales Press. Forthcoming.

Lichtenberg, J. (2010). Negative Duties, Positive Duties, and the 'New Harms.' Ethics, 120(3), 557-578.

Locke, J. (1988). Two Treatises of Government. (P. Laslett, Ed.). Cambridge: Cambridge University Press.

Lohmann, G. (1998). Müssen die Menschenrechte durch eine allgemeine Erklärung der Menschenpflichten ergänzt werden? Perspektiven Ds, Zeitschrift Der Hochschulinitiative Demokratischer Sozialismus, 15(2), $123-138$.

Louden, R. B. (1983). Rights Infatuation and the Impoverishment of Moral Theory. The Journal of Value Inquiry, 17, 87-102.

Maastricht Guidelines on Violations of Economic, Social and Cultural Rights. Reprinted in (1998) Human Rights Quarterly, 20(3), 691-704.

Machiavelli, N. (1970). The Discourses. (Leslie J. Walker, Trans.). New York: Penguin Books.

Machiavelli, N. (2013). Discorsi sopra la prima deca di Tito Livio. Milan: Bur Rizzoli.

Malik, C. H. Introduction. In Nolde, O. F. (1968). Free and Equal: Human Rights in Ecumenical Perspective. Geneva: World Council of Churches.

Martinez-Torron, J. (2003). The Permissible Scope of Legal Limitations on the Freedom of Religion or Belief: The European Convention on Human Rights. Global Jurist Advances, 3(2), 1-40.

Marx, K. (2000). On the Jewish Question. In D. McLellan (Ed. \& Trans.), Karl Marx: Selected Writings (pp. 46-70). (2 ${ }^{\text {nd }}$ ed.). Oxford: Oxford University Press.

Maynor, J. W. (2003). Republicanism in the Modern World. Cambridge: Polity Press.

Mertens, T.J.M. (in press). On Kant's Duty to Speak the Truth. Kantian Review.

Michels, A. (2006). Citizen Participation and Democracy in the Netherlands. Democratization, 13(2), 323-339.

Michels, A. (2011). Innovations in Democratic Governance: How Does Citizen Participation Contribute to a Better Democracy? International Review of Administrative Sciences, 77(2), 275-293.

Mieth, C. (2008). World Poverty as a Problem of Justice? A Critical Comparison of Three Approaches. Ethical Theory and Moral Practice, 11(1), 15-36.

Mieth, C. (2012). On Human Rights and the Strength of Corresponding Duties. In G. Ernst \& J-C. Heilinger (Eds.), The Philosophy of Human Rights (pp. 159-184). Berlin: Walter de Gruyter.

Mill, J. S. (2008). Considerations on Representative Government. In J. Gray (Ed.), On Liberty and Other Essays (pp. 203-467). New York: Oxford University Press.

Mill, J. S. (2008). On Liberty. In J. Gray (Ed.), On Liberty and Other Essays (pp. 1-128). New York: Oxford University Press.

Mill, J. S. (2008). Utilitarianism. In J. Gray (Ed.), On Liberty and Other Essays (pp. 129-201). New York: Oxford University Press. 
Miller, D. (2007). National Responsibility and Global Justice. Oxford: Oxford University Press.

Montesquieu, C. de. (1989). The Spirit of the Laws. (A. M. Cohler, B. C. Miller, \& H. S. Stone, Eds. \& Trans.). Cambridge: Cambridge University Press.

Morsink, J. (1999). The Universal Declaration of Human Rights: Origins, Drafting and Intent. Philadelphia: University of Pennsylvania Press

Mutua, M. W. (1995). The Banjul Charter and the African Cultural Fingerprint: An Evaluation of the Language of Duties. Virginia Journal of International Law, 35, 339-380.

Mutua. M. W. (2008). Human Rights in Africa: The Limited Promise of Liberalism. African Studies Review, 51(1), 17-39.

Nussbaum, M. (2000). Duties of Justice, Duties of Material Aid: Cicero's Problematic Legacy. The Journal of Political Philosophy, 8(2), 176-206.

Nussbaum, M. (2006). Frontiers of Justice: Disability, Nationality, Species Membership. Cambridge (Mass.): Belknap Press of Harvard University Press.

O'Neill, O. (1990). The Great Maxims of Justice and Charity. In Constructions of Reason: Explorations of Kant's Practical Philosophy (pp. 219-233). Cambridge: Cambridge University Press.

O’Neill, O. (1990). Children's Rights and Children's Lives. In Constructions of Reason: Explorations of Kant's Practical Philosophy (pp. 187-205). Cambridge: Cambridge University Press.

O’Neill, O. (1996). Towards Justice and Virtue: A Constructive Account of Practical Reasoning. Cambridge: Cambridge University Press.

O’Neill, O. (2000). Transnational Economic Justice. In Bounds of Justice (pp. 115-142). Cambridge: Cambridge University Press.

O’Neill, O. (2002). Instituting Principles: Between Duty and Action. In M. Timmons (Ed.), Kant's Metaphysics of Morals: Interpretive Essays (pp. 331-347). Oxford: Oxford University Press.

O'Neill, O. (2013). Acting on Principle: An Essay on Kantian Ethics. Cambridge: Cambridge University Press.

Oxfam (2009). Education for Global Citizenship. Retrieved from http://www.oxfam.org.uk/ /media/Files/Education/Global\%20Citizenship/education_for_global_citizenship_a_guide_for_schools.ashx.

Pasqualucci, J. (2010). The Americas. In D. Moeckli, S. Shah, \& S. Sivakumaran (Eds.), International Human Rights Law (pp. 433-453). Oxford: Oxford University Press.

Peterson, A. (2011). Civic Republicanism and Civic Education: The Education of Citizens. New York: Palgrave Macmillan.

Pettit, P. (1997). Republicanism: A Theory of Freedom and Government. Oxford: Oxford University Press.

Pinheiro Walla, A. (2015). Kant's Moral Theory and Demandingness, Ethical Theory and Moral Practice. Advance online publication. doi:10.1007/s10677-015-9600-x.

Plato. (1937). The Republic. (P. Shorey, Trans.). Cambridge, MA: Harvard University Press.

Pogge, T. (1992). O'Neill on Rights and Duties. Philosophische Studien, 43, 233-247.

Pogge, T. (2002). Human Rights and Human Responsibilities. In P. De Greiff \& C.P. Cronin (Eds.), Global Justice and Transnational Politics (pp. 151-195). Cambridge, MA: The MIT Press.

Pogge, T. (2005). Reply to the Critics: Severe Poverty as a Violation of Negative Duties. Ethics and International Affairs, 19(1), 55-83.

Pogge, T. (2008). World Poverty and Human Rights: Cosmopolitan Responsibilities and Reforms (2 ${ }^{\text {nd }}$ ed.). Cambridge: Polity Press.

Pufendorf, S. (1729). The Law of Nature and Nations. (B. Kennett, Trans., J. Barbeyrac, Ed.). London

Pufendorf, S. (1994). On the Law of Nature and of Nations in Eight Books. In C.L. Car (Ed.), M.J. Seidler (Trans.), The Political Writings of Samuel Pufendorf (pp. 93-268). Oxford: Oxford University Press.

Quong, J. (2011). Liberalism Without Perfection. Oxford: Oxford University Press.

Rawls, J. (1999). A Theory of Justice (Revised Ed.). Cambridge (Mass): Belknap Press of Harvard University Press

Rawls, J. (1999). Legal Obligation and the Duty of Fair Play. In S. Freeman (Ed.), Collected Papers (pp. 117-129). Cambridge, MA: Harvard University Press.

Rawls, J. (2001). Justice as Fairness: A Restatement. (Erin Kelly, Ed.). Cambridge, MA: Belknap Press of Harvard University Press.

Rawls, J. (2005). Political Liberalism (Expanded Ed.). New York: Columbia University Press.

Raz, J. (1986). The Morality of Freedom. Oxford: Oxford University Press.

Roff, H. M. (2013). Global Justice, Kant and the Responsibility to Protect: A Provisional Duty. New York: Routledge;

Rousseau, J.-J. (1984). A Discourse on Inequality. (M. Cranston, Trans., M. Cranston, Ed.). London: Penguin Books.

Rousseau, J.-J. (1997). Considerations on the Government of Poland and on its Projected Reformation. In V. Gourevitch (Ed. \& Trans.), The Social Contract and Other Later Political Writings (pp. 177-260). Cambridge: Cambridge University Press.

Rousseau, J.-J. (1997). Discourse on Political Economy. In V. Gourevitch (Ed. \& Trans.), The Social Contract and Other Later Political Writings (pp. 3-38). Cambridge: Cambridge University Press.

Rousseau, J.-J. (1997). Of the Social Contract. In V. Gourevitch (Ed.), V. Gourevitch (Trans.), The Social Contract and Other Later Political Writings (pp. 39-152). Cambridge: Cambridge University Press.

Sandel, M. J. (1996). Democracy's Discontent: America in Search of a Public Philosophy. Cambridge (Mass): Belknap Press of Harvard University Press. 
Satz, D. (2005). What Do We Owe the Global Poor? Ethics and International Affairs, 19(1), 47-54.

Saul, B. (2001). In the Shadow of Human Rights: Human Duties, Obligations, and Responsibilities. Columbia Human Rights Law Review, 32, 565-624.

Saul, B., Kinley, D., \& Mowbray, J. (2014). The International Covenant on Economic, Social and Cultural Rights: Commentary, Cases, and Materials. Oxford: Oxford University Press.

Scheffler, S. (2001). Individual Responsibility in a Global Age. In Boundaries and Allegiances: Problems of Justice and Responsibility in Liberal Thought (pp. 32-47). Oxford: Oxford University Press.

Schneewind, J.B. (1998). The Invention of Autonomy: A History of Modern Moral Philosophy. Cambridge: Cambridge University Press.

Schumpeter, J. A. (1976). Capitalism, Socialism and Democracy. London: George Allen \& Unwin. 269-70.

Sensen, O. (2011). Human Dignity in Historical Perspective: The Contemporary and Traditional Paradigms. European Journal of Political Theory, 10(1), 71-91.

Sensen, O. (2013). Duties to Others From Respect (TL 6:462-468). In A. Trampota, O. Sensen \& J. Timmermann (Eds.), Kant's 'Tugendlehre': A Comprehensive Commentary (pp. 343-363). Berlin: Walter de Gruyter.

Shue, H. (1980). Basic Rights: Subsistence, Affluence, and U.S. Foreign Policy. Princeton: Princeton University Press.

Simmonds, N.E. (1998). Rights as the Cutting Edge. In M.H. Kramer, N.E. Simmonds \& H. Steiner, A Debate Over Rights: Philosophical Enquiries (pp. 113-232). Oxford: Oxford University Press.

Simmons, A. J. (1979). Moral Principles and Political Obligations. Princeton: Princeton University Press.

Singer, P. (1972). Famine, Affluence, and Morality. Philosophy and Public Affairs, 1(3), 229-243.

Smith, W. (2009). The Transformation of Political Community and Conceptions of Global Citizenship. In P. Hayden (Ed.), The Ashgate Research Companion to Ethics and International Relations (pp. 461-477). Surrey: Ashgate.

Spragens, T. A. (2004). Legislating Morality in Liberal Democracies. In A. Etzioni, A. Volmert, \& E. Rothschild (Eds.), The Communitarian Reader: Beyond the Essentials (pp. 55-60). Oxford: Rowman and Littlefield Publishers.

Statman, D. (1996). Who Needs Imperfect Duties? American Philosophical Quarterly, 33(2), 211-224.

Steiner, H. J., \& Alston, P. (1996). International Human Rights in Context: Law, Politics, Morals. Oxford: Oxford University Press.

Stemplowska, Z. (2009). On the Real World Duties Imposed on Us by Human Rights. Journal of Social Philosophy, 40(4), 466-487.

Tan, K. C. (2004). Justice Without Borders: Cosmopolitanism, Nationalism and Patriotism. Cambridge: Cambridge University Press.

Tasioulas, J. (2007). The Moral Reality of Human Rights. In T. Pogge (Ed.), Freedom From Poverty as a Human Right: Who Owes What to the Very Poor? (pp. 75-101). Oxford: Oxford University Press.

Timmermann, J. (2005). Good but Not Required? - Assessing the Demands of Kantian Ethics. Journal of Moral Philosophy, 2(1), 9-27.

Timmermann, J. (2013). Kantian Dilemmas? Moral Conflict in Kant's Ethical Theory. Archiv Für Geschichte Der Philosophie, 95(1), 36-64.

Tyler, T. R. (2006). Why People Obey the Law. Princeton: Princeton University Press.

United Nations Development Programme. (2011). Human Development Report 2011. Sustainability and Equity: A Better Future for All. Retrieved from http://www.undp.org/content/dam/undp/library/corporate/ HDR/2011\%20Global\%20HDR/English/HDR_2011_EN_Complete.pdf.

Van Boven, T. (2010). Categories of Rights. In D. Moeckli, S. Shah, \& S. Sivakumaran (Eds.), International Human Rights Law (pp. 173-188). Oxford: Oxford University Press.

Van Leuven, N. (2009). Contracten en mensenrechten: Een mensenrechtelijke lezing van het contractrecht. Antwerpen: Intersentia.

Viroli, M. (1988). Jean-Jacques Rousseau and the “Well-Ordered Society.” (D. Hanson, Trans.). Cambridge: Cambridge University Press.

Waldron, J. (1981). A Right to Do Wrong. Ethics, 92(1), 21-39.

Waldron, J. (1993). Liberal Rights: Collected Papers 1981-1991. Cambridge: Cambridge University Press.

Waldron, J. (2003). Teaching Cosmopolitan Right. In K. McDonough \& W. Feinberg (Eds.), Citizenship and Education in Liberal-Democratic Societies (pp. 23-55). Oxford: Oxford University Press.

Willaschek, M. (2009). Right and Coercion: Can Kant's Conception of Right be Derived from his Moral Theory? International Journal of Philosophical Studies, 17(1), 49-70.

Williams, H. (2012). Kant and the End of War: a Critique of Just War Theory. London: Palgrave Macmillan;

Wolff, R. P. (1998). In Defense of Anarchism ( $2^{\text {nd }}$ ed.). Berkeley: University of California Press.

Wood, A. (2002). The Final Form of Kant's Practical Philosophy. In M. Timmons (Ed.), Kant's Metaphysics of Morals: Interpretive Essays (pp. 1-21). Oxford: Oxford University Press.

Young, I. M. (2013). Responsibility for Justice. New York: Oxford University Press. 


\section{TABLE OF CASES}

African Commission on Human and Peoples' Rights

Ogoni People v. Nigeria. Judgment of May 27, 2002. ACHPR/COMM/A044/1.

\section{European Court of Human Rights}

Thorgeirson v. Iceland. 25 June 1992. Application No. 13778/88.

Pretty v. United Kingdom. 29 April 2002. Application No. 2346/02.

Norwood v. the United Kingdom. 16 November 2004. Application No. 23131/03.

Pavel Ivanov v. Russia. 20 February 2007. Application No. 35222/04.

Stoll v. Switzerland. Grand Chamber. 10 December 2007. Application No. 69698/01.

Inter-American Court of Human Rights

Case of "Street Children" (Villagrán Morales et al.) v. Guatemala. Judgment of November 19, 1999 (Merits). Series C No. 63.

Case of the Yakye Axa Indigenous Community v. Paraguay. Judgment of June 17, 2005. Series C No 125. 


\section{TABLE OF HUMAN DUTIES DECLARATIONS}

InterAction Council. A Universal Declaration of Human Responsibilities. (1997, September 1). Retrieved from http:// interactioncouncil.org/universal-declaration-human-responsibilities.

Lord Chancellor and Secretary of State for Justice. Rights and Responsibilities: Developing Our Constitutional Framework. (2009, March). Retrieved from https://www.gov.uk/government/uploads/system/ uploads/attachment_data/file/228938/7577.pdf.

Nationale Conventie. Hart voor de publieke zaak. (2006, September). Retrieved from http://www.parlement. com/9291000/d/natconv.pdf.

Parliament of the World's Religions. Declaration Toward a Global Ethic. (1993, September 4). Retrieved from http:// www.parliamentofreligions.org/_includes/fckcontent/file/towardsaglobalethic.pdf.

Parliamentary Assembly of the Council of Europe (PACE). Fundamental Rights and Responsibilities. Doc. 12777. (2011, October 24). Retrieved from http://assembly.coe.int/nw/xml/XRef/Xref-XML2HTML-en. asp?fileid $=12965 \&$ lang $=$ EN.

UNCHR. Promotion and Protection of Human Rights: Human Rights and Human Responsibilities. UN Doc. E/ CN.4/2003/105. (2003, March 17). Retrieved from http://daccess-dds-ny.un.org/doc/UNDOC/ GEN/G03/120/23/PDF/G0312023.pdf?Open Element

Valencia Third Millennium Foundation. Declaration of Human Duties and Responsibilities. (1998). Retrieved from http://globalization.icaap.org/content/v2.2/declare.html. 


\section{TABLE OF UNITED NATIONS DOCUMENTS}

\section{United Nations Commission on Human Rights}

UNCHR. Report on the Fifty-Sixth Session. UN Doc. E/CN.4/2000.167. Resolution 2000/63. Retrieved from http:// www.un.org/en/terrorism/pdfs/2/G0014048.pdf

UNCHR. Report on the Fifty-Ninth Session. UN Doc. E/CN.4/2003.135. Retrieved from http://www.un.org/en/terrorism/pdfs/2/G0215272.pdf

UNCHR. Report on the Sixtieth Session. UN Doc. E/CN.4/2004/127. Retrieved from http://www.un.org/en/terrorism/pdfs/2/G0414734.pdf

United Nations Committee on Economic, Social and Cultural Rights

These documents can be consulted online at: http://www.ohchr.org/en/hrbodies/cescr/pages/ cescrindex.aspx

CESCR. General Comment No. 3: The Nature of States Parties Obligations (Art. 2(1)). E/1991/23 (14 December 1990). CESCR. General Comment 12: The Right to Adequate Food (Art. 11). E/C.12/1999/5 (12 May 1999).

CESCR. General Comment No. 14: The Right to the Highest Attainable Standard of Health (Art. 12). E/C.12/2000/4 (11 August 2000).

CESCR. Statement on Poverty and the ICESCR, E/C.12/2001/10 (10 May 2001).

\section{United Nations Economic and Social Council}

ECOSOC. Statement on behalf of the European Union (July 22, 2004). PRES04-217 EN. Retrieved from http://eu-un. europa.eu/articles/en/article_3700_en.htm.

The Travaux Préparatoires of the Universal Declaration of Human Rights

These documents can be consulted online at http://research.un.org/en/undhr.

UN Doc. E/CN.4/SR.8 (31 January 1947).

UN Doc. E/CN.4/SR.14 (5 February 1947).

UN Doc. E/CN.4/AC.1/3 (4 June 1947).

UN Doc. E/CN.4/AC.1/3/Add.1. (11 June 1947).

UN Doc. E/CN.4/AC.1/SR.3 (13 June 1947).

UN Doc. E/CN.4/AC.1/W.2/Rev.2 (20 June 1947).

UN Doc. E/CN.4/AC.1/SR.5 (8 December 1947).

UN Doc. E/CN.4/SR.67. (25 June 1948).

UN Doc. E/CN.4/SR.77 (28 June 1948).

UN Doc. A/C.3/261 (12 October 1948).

UN Doc. A/C.3/304/Rev.1 (30 October 1948).

UN Doc. A/C.3/345 (17 November 1948).

UN Doc. A/C.3/304/Rev.2 (20 November 1948). 


\section{CURRICULUM VITAE}

Eric R. Boot studied philosophy and literary studies at the University of Amsterdam, the Naples Eastern University and the Free University of Berlin. In 2010 he graduated with a MA thesis on the concepts of freedom and responsibility in the works of Kant and Heidegger. As of June 2011 he started work on his PhD in philosophy of law (supervised by prof. dr. Thomas Mertens and dr. Ronald Tinnevelt) at the Faculty of Law of the Radboud University Nijmegen. For the duration of the spring semester 2013 he visited the Department of Philosophy of the University of Pennsylvania as a visiting scholar. His supervisor there was prof. dr. Kok-Chor Tan. Following the completion of his $\mathrm{PhD}$ he will start work at Leiden University on the three-year postdoctoral project "Unauthorized Disclosures," which is part of the project "Democratic Secrecy: Philosophical Analysis of the Role of Secrecy in Democratic Governance." This project is funded by the European Research Council and will be executed under the supervision of dr. Dorota Mokrosinska. 